UNIVERSIDADE DE SÃO PAULO

FACULDADE DE FILOSOFIA, LETRAS E CIÊNCIAS HUMANAS

DEPARTAMENTO DE LETRAS ORIENTAIS

PROGRAMA DE PÓS-GRADUAÇÃO EM ESTUDOS JUDAICOS E ÁRABES

\author{
MURILO SEBE BON MEIHY
}

HABEMUS AFRICAS:

ISLÃ, RENASCIMENTO E ÁFRICA EM JOÃO LEÃO

AFRICANO (SÉC. XVI)

São Paulo

2013 
UNIVERSIDADE DE SÃO PAULO

FACULDADE DE FILOSOFIA, LETRAS E CIÊNCIAS HUMANAS

DEPARTAMENTO DE LETRAS ORIENTAIS

PROGRAMA DE PÓS-GRADUAÇÃO EM ESTUDOS JUDAICOS E ÁRABES

MURILO SEBE BON MEIHY

\section{HABEMUS AFRICAS: \\ ISLÃ, RENASCIMENTO E ÁFRICA EM JOÃO LEÃO \\ AFRICANO (SÉC. XVI)}

Tese apresentada ao Programa de Estudos Judaicos e Árabes do Departamento de Letras Orientais da Faculdade de Filosofia, Letras e Ciências Humanas da Universidade de São Paulo, para a obtenção do título de Doutor em Letras

Orientador: Prof. Dr. Mamede Mustafá Jarouche

São Paulo

2013 



\title{
HABEMUS AFRICAS: ISLÃ, RENASCIMENTO E ÁFRICA EM JOÃO LEÃO AFRICANO (SÉC. XVI)
}

\author{
MURILO SEBE BON MEIHY
}

\section{BANCA EXAMINADORA}

(Nome e Assinatura)

(Nome e Assinatura)

(Nome e Assinatura)

(Nome e Assinatura)

(Nome e Assinatura)

Tese defendida e aprovada em 
A Ibrahim Nagib Bon Meihy e Catarina Sebe: onde tudo começou 


\section{AGRADECIMENTOS}

Ao meu orientador, Mamede Mustafá Jarouche.

Aos avaliadores desta Tese, Professores Marco Américo Lucchesi, Maria Cristina Cortez Wissenbach, Paulo Gabriel Hilu da Rocha Pinto e Safa Jubran.

Aos professores Arlene Clemesha, Beatriz Bissio, Felipe Charbel Teixeira, Maurício Parada, Miguel Attie Filho e Silvia Patuzzi.

Aos professores Antonio Edmilson Martins Rodrigues, Berenice Cavalcante, Marcelo Jasmin e Zilda Iokoi.

Aos funcionários do Departamento de Letras Orientais Álvaro, Iva, Jorge, Luís, Maribel e Patrícia.

Ao sistema Janus, por fazer minha matrícula voltar a viver.

À minha família: um agradecimento geral porque se eu esquecer alguém, a Guerra Civil Libanesa vai parecer festa de criança.

Aos amigos Amanda Azis, Amanda Danelli, Briana Rodrigues, Bruno Franklin, Carlos Alberto Nicoli Sansevero, Cássio Trevisani, Daniel Pinha, Eduardo Felippe, Fabiana Haiashida, Henrique Estrada, Hugo Sérgio Assis Júnior, Leonardo Augusto, Michel Gherman, Muna Omran, Rodrigo Maron, Veridiana Deli, Viviane Araújo. 
À Graziela, minha única Fortuna e meu Renascimento.

Por fim, agradeço àqueles cujo nome não preciso mencionar, cuja presença não precisa ser constante, mas que de onde estiverem, terão a certeza de minha eterna gratidão. 
Aqui ninguém vai pro céu (Criolo) 


\section{RESUMO}

MEIHY, M. S. B. Habemus Africas: Islã, Renascimento e África em João Leão Africano (século XVI). 2013. 273 f. Tese (Doutorado) - Faculdade de Filosofia, Letras e Ciências Humanas, Universidade de São Paulo, São Paulo, 2013.

A obra mais emblemática do viajante do século XVI João Leão Africano, intitulada Della descrittione dell'Africa et delle cose notabli che ivi sono, sugere a existência de duas racionalidades integradas: a árabe-islâmica e a europeia-latina. A presente tese busca identificar essas duas camadas de racionalidade no trabalho de João Leão Africano, mostrando que o século XVI produziu um conhecimento plural entre essas duas matrizes culturais, que se relacionavam intensamente no período do Renascimento. Seja pela perspectiva de conflito, pela interação cultural ou pela negociação comercial entre povos cristãos e muçulmanos, o Norte da África e o Mediterrâneo se consolidaram no século XVI como espaços simbióticos. Esses elementos conjunturais, combinados à trajetória pessoal de João Leão Africano e sua relação com o Papa Leão $\mathrm{X}$, moldaram sua visão sobre a África por meio de uma concepção fluida e intersticial do continente. A reflexão sobre o mundo moderno do referido viajante é reforçada pela formação de um padrão de pensamento definido por conceitos como: astúcia, tradução cultural, Fortuna, vergonha, incerteza, e fluidez civilizacional.

Palavras-chave: 1. Islã 2. Renascimento 3. África 4. João Leão Africano 5. Tradução cultural 6. Colonialidade 


\begin{abstract}
MEIHY, M. S. B. Habemus Africas: Islã, Renascimento e África em João Leão Africano (século XVI). 2013. 273 f. P.h.D thesis. FFLCH, University of São Paulo. São Paulo, 2013

The most representative work of the sixteenth century traveler Leo Africanus, entitled Della descrittione dell'Africa et delle cose che notabli ivi sono, suggests the existence of two intertwined rationalities: the Arab-Islamic and the European-Latin. This research seeks to identify these two layers of rationality in the work of Leo Africanus, showing that the sixteenth century produced plural knowledge between these two cultural sources, intensely connected during the Renaissance. Either from the perspective of conflict, of the cultural interaction or of the commercial negotiation between Christian and Muslim peoples, North Africa and the Mediterranean developed in the sixteenth century as symbiotic spaces. These circumstantial elements, combined with the personal path of Leo Africanus, and his relationship with Pope Leo $X$, shaped his view of Africa through a fluid and interstitial conception of the continent. Leo Africanus' idea about the modern world is strengthened by a thought pattern raised and defined by concepts such as cunning, cultural translation, Fortuna, shame, uncertainty, and civilization fluidity.
\end{abstract}

Keywords: 1. Islam 2. Renaissance 3. Africa 4. Leo Africanus 5. Cultural Translation 6. Coloniality 


\section{LISTA DE IMAGENS}

Imagem 1: La Sagrada Familia, obra de Luis de Morales..............................................25

Imagem 2: Comparação entre detalhe da obra de Luis de Morales e o horóscopo de Jesus

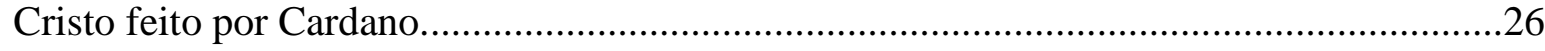

Imagem 3: Santa Catalina de Alejandría, obra de Fernando Yáñez de la Almedina...........35

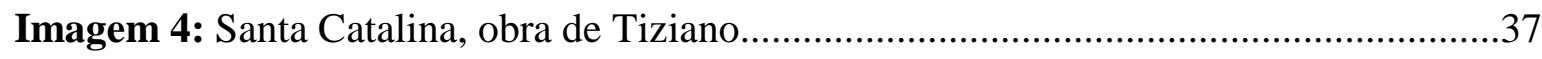

Imagem 5: Ritratto di giovane romana con cesto di frutta, obra de Sebastiano del

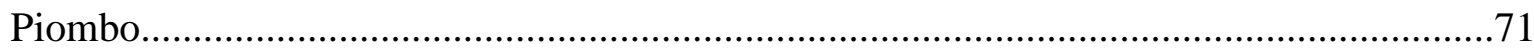

Imagem 6: Ritratto di umanista, obra de Sebastiano del Piombo....................................73

Imagem 7: Fortuna, gravura de Hans Sebald Beham...................................................94

Imagem 8: Infortunium, gravura de Hans Sebald Beham...............................................96

Imagem 9: Comparação entre as telas $\mathrm{O}$ cambista e sua mulher, de Quentin Matsys, e O cambista e sua mulher, de M. van Reymerswaele......................................................118

Imagem 10: Detalhe da obra O cambista e sua mulher, de Quentin Matsys...................119

Imagem 11: Outro detalhe da obra $\mathrm{O}$ cambista e sua mulher, de Quentin Matsys............121 


\section{LISTA DE TABELAS}

Tabela 1: Os quatro elementos na medicina humoral...............................................21

Tabela 2: Ação da Fortuna sobre os homens.............................................................92

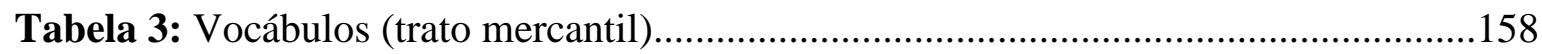

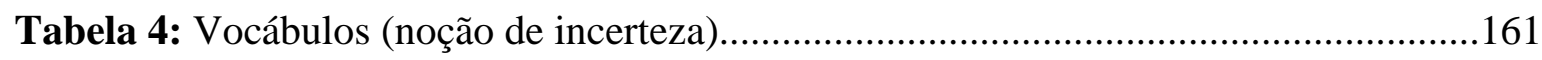

Tabela 5: Potenciais produtos comerciais citados por João Leão Africano.......................163 


\section{SUMÁRIO}

1 INTRODUÇÃO: MALANDRO NÃO COMEÇA, INAUGURA!....... 15

2 O SÉCULO FEITO DE FOGO ............................................................. 34

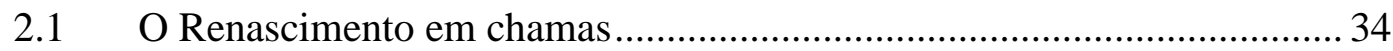

2.2 Quando o sangue ferve: a Modernidade pelo confronto.......................... 41

2.3 Onde há fumaça, nem sempre há fogo: a Modernidade pela negociação.. 49

2.4 A Modernidade simbiótica: o Norte da África ...................................... 55

2.5 As cinzas do conhecimento: Ibn Khaldun, João Leão Africano e a história

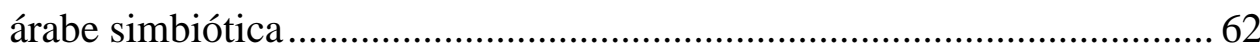

3 O HOMEM FEITO DE TERRA...................................................... 70

3.1 O que veio do pó: Leão Africano como um homem de sua época............ 70

3.2 O que se molda como barro: a tradução cultural ..................................... 77

3.3 Com os pés na terra da racionalidade europeia-latina: Virtú e Fortuna.....90

3.4 A terra da vergonha: a racionalidade árabe-islâmica entre a vergonha e a honra. 101

3.5 Enterrar a cabeça na areia: a experiência da incerteza no pensamento algébrico de Leão Africano................................................................108

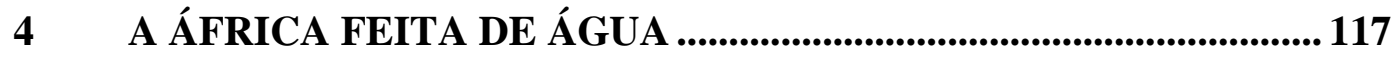

4.1 A correnteza do mundo: o comércio................................................... 117

4.2 Águas revoltas: a questão do domínio sobre o mar .............................. 124

4.3 Às lágrimas: a questão da colonialidade e o espaço do interstício........... 129

4.4 Escorre pelas mãos: África e a fluidez civilizacional - "Umrān” e trânsito cultural 
4.5 Mare nostrum: ethos mercantil, vocabulário comercial e o uso do

italiano

5 CONSIDERAÇÕES FINAIS: TODA CONCLUSAO É FEITA DE

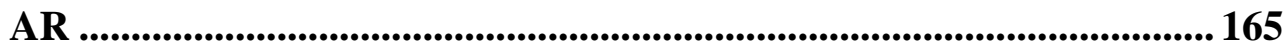

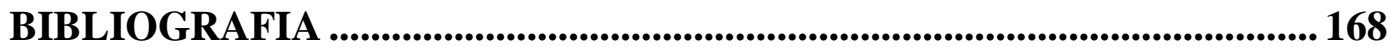

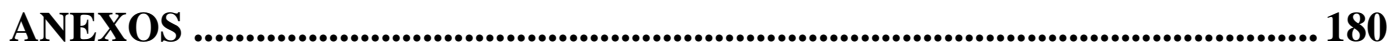

I Tradução do primeiro livro de Della descrittione dell'Africa et delle cose

notabli che ivi sono .......................................................................... 180

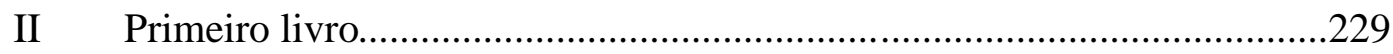




\section{Introdução}

\section{Malandro não começa, inaugura!}

A arte de enganar alguém com o intuito de garantir a própria sobrevivência é uma parte curiosa e desafiadora da experiência humana ao longo do tempo. Em campos distintos do conhecimento, a ideia de se levar o outro intencionalmente ao equívoco é uma situação social frequente.

Os recentes trabalhos sobre o funcionamento do cérebro humano desenvolvidos por Scott Huettel, da Universidade Duke, identificaram uma única região do cérebro como a responsável por qualquer tomada de decisões que envolva outro ser humano, a junção temporal parietal. Isso mostra que as interações sociais obrigam o cérebro a operar de forma particular ao decidirmos enganar um antagonista. Estudiosos que analisam os percursos do cérebro nas ações decisórias, como o neurocientista Huettel, são categóricos: "Há diferenças neurais que são fundamentais entre as decisões tomadas em um contexto social e um não social ${ }^{1 "}$.

O engano, entendido como o favorecimento proposital da imprecisão, é parte da própria natureza humana, e ao ser movido por circunstâncias de interação social, precisa ser contextualizado, considerando-se tanto a razão que leva o indivíduo a promover a ambiguidade, quanto os padrões sociais de sua época. A trapaça, fundamento incontestável de jogos interativos entre os homens, não pode ser tomada como um elemento exclusivamente negativo, mas, quando relativizada do ponto de vista moral, pode revelar certa capacidade de transformação do mundo. Por exemplo, basta que se observe a linguagem como uma ferramenta conjuntural de um artifício de sociabilidade corriqueiro: falar, escrever e contar é, sobretudo, sobreviver em tempos de incerteza.

A linguagem é historicamente retratada na cultura árabe-islâmica como um instrumento sedutor de sublevação da ordem, seja quando empregada de maneira literária ou político-institucional. Para a sociedade árabe, saber utilizar as palavras e conceitos de maneira atraente é uma postura sediciosa; o que transforma todo e qualquer texto em um jogo sutil que deve produzir encantamento no leitor.

$\mathrm{Na}$ literatura árabe clássica, as referências ao poder intrigante da linguagem são incessantes. A obra mais difundida da cultura árabe-islâmica, conhecida no Ocidente

\footnotetext{
${ }^{1}$ http://noticias.uol.com.br/ciencia/ultimas-noticias/efe/2012/07/05/decisao-de-enganar-alguem-vem-dearea-especifica-do-cerebro-diz-estudo.htm
} 
como "Livro das mil e uma noites",", reforça o sentido ardiloso da palavra bem empregada ao transformar a filha do vizir (Scherazade) em uma personagem astuta que, pela sedução da palavra, supera a tirania do rei Shariar e altera seu destino fatal. Todas as noites ao se deitar com seu próprio algoz, Scherazade converte o Infortunium em Fortuna, recorrendo ao estratagema de seduzir, envolver e positivamente enganar o seu interlocutor. Ao longo de inúmeras noites em que a morte parecia ser o seu destino, Scherazade teve vários filhos com o rei, negociando ao final não somente a preservação de sua vida, como também a sua condição de rainha definitiva de um mundo mais livre e justo.

Os neurocientistas teriam poupado muito tempo de pesquisa se tivessem conhecido a história de Scherazade. O mapeamento da junção temporal parietal durante uma situação de escolha pelo engano do outro é apenas uma linguagem específica que legitima socialmente o que Scherazade executa com um sorriso e uma boa conversa: ser o que o outro precisa ouvir. Em cada época, em cada contexto, quando a realidade impõe limites à vida, é preciso convencer o mundo da capacidade criadora da boa trapaça.

Nesse sentido, sabendo que todo individuo social é um trapaceiro em potencial, é possível imaginar um velhaco de caminhar cambaleante andando pelas ruas de uma cidade como Roma, Florença, Milão ou Veneza em pleno século XVI? Certamente não, mas isso não significa que nos primórdios da Idade Moderna não existam homens que precisem de certo ardil para sobreviver. A vida pode ser penosa para muitos tipos humanos ao longo da história, e o que muda com o tempo é apenas o perfil social daqueles que precisam driblar situações de dificuldade de sobrevivência para escapar das vicissitudes cotidianas.

Considerar a existência de algum tipo de "malandro" no século XVI não é anacronismo. O Vocabolario Degli Accademici Della Crusca ${ }^{3}$, a primeira edição de um léxico linguístico italiano, foi publicado em 1612 como parte dos trabalhos da Accademia Della Crusca, fundada em Florença no ano de 1583. Já em seu primeiro trabalho, o citado Vocabolario contém algumas palavras indicativas de que o homem do século XVI, principalmente na Península Itálica, conhecia muito bem os "malandros" de sua época. O primeiro dos termos possíveis era o vocábulo malandrino, que aparece

\footnotetext{
${ }^{2}$ Livro das Mil e uma noites. Tradução: Mamede Mustafá Jarouche. Editora: Biblioteca Azul. 2012. 4 volumes.

${ }^{3}$ O Vocabolario Degli Accademici Della Crusca me foi indicado pela Profa. Silvia Patuzzi, cujas discussões sobre o Renascimento foram essenciais para essa tese.
} 
prontamente com duas acepções possíveis: 1) ladrão de estradas ${ }^{4}$; e 2) que se fez patife, da raça dos canalhas ${ }^{5}$. Do castelhano, transmitido pelo francês e pelo catalão, existe ainda uma terceira definição indireta relacionada à malandria, uma doença comum aos cavalos e que servia para se referir a uma das variações da lepra humana.

Mas o tipo social que se procura e que circula livremente na época do Renascimento não é um ladrão profissional, nem mesmo um doente socialmente execrável. O que se procura são homens da primeira metade do século XVI que, diante das adversidades, viram suas vidas alteradas abruptamente, e, não obstante, reagiram a essas desventuras ocasionais por meio de seus textos. Por essa razão, a palavra do vocabulário desse período que melhor expressa o sentido de "ardil" social presente em certas figuras que serão aqui retratadas era "scaltrito", ou "scalterito", com o sentido de pessoa astuta, sagaz ${ }^{7}$.

Se o melhor caminho para encontrar esses homens fosse buscá-los apenas pelos seus próprios nomes, isso seria uma tarefa monástica, hercúlea, portanto, incompatível com o tema da astúcia e da malandragem apresentado. O que se propõe aqui é buscar obras do século XVI que construíram sua fama à revelia da biografia caótica de seus autores, e, assim, garantiram a sobrevivência e o sustento de seus artífices pela notoriedade dos textos.

Em ordem cronológica de publicação, os primeiros escritos que se encaixam nessa perspectiva são: De occulta philosophia libri tres ${ }^{8}$, e De incertitudine et vanitate scientiarum et artium $^{9}$, obras do polemista alemão Heinrich Cornelius Agrippa von Nettesheim (de agora em diante citado como Agrippa). O primeiro texto é conhecido como o estudo mais completo e difundido sobre o poder da magia e do ocultismo, enquanto o segundo é o seu oposto, o repúdio incrédulo e destrutivo de toda forma de conhecimento produzida pela razão humana, inclusive o próprio De occulta philosophia libri três. A escrita de uma obra que relativiza a credibilidade de um texto anterior, ambos feitos pelo mesmo autor, pode parecer uma contradição, mas é apenas uma demonstração da existência de um sistema de pensamento comum ao século XVI baseado em uma definição positiva da incerteza.

\footnotetext{
4 “Rubator di strade”, do latim: latro.

" "Che ha del malandrino, di razza di malandrino."

6 "Astuto, sagace", do latim: "callidus, sagax".

${ }^{7} \mathrm{Na}$ versão em língua inglesa de sua obra sobre Leão Africano, Natalie Zemon Davis utiliza o termo "Trickster" para defini-lo. A palavra sugere um sentido próximo ao que se pretende atribuir aqui ao vocábulo scaltrito: um enganador astuto próprio de contextos interculturais.

${ }^{8}$ Três livros de filosofia oculta.

${ }^{9}$ Sobre a incerteza e vanglória das ciências.
} 
A matriz cultural de Agrippa era a mesma de grande parte dos pensadores de sua época, o Humanismo renascentista. Assim como os homens de seu circuito intelectual, Agrippa concentrava seus esforços em releituras dos textos da Antiguidade, renovando a reflexão sobre o mundo moderno a partir de debates conceituais extraídos de obras e autores antigos. O que diferia o polemista alemão de outras figuras clássicas do Humanismo eram as fontes utilizadas para a produção de um conhecimento embasado em novas apropriações do passado. Enquanto grande parte dos humanistas se aprofundava em vultos do pensamento antigo, como Aristóteles, Sêneca, Epicuro, Cícero, Políbio e os demais pensadores de excelente reputação nas universidades modernas, Agrippa voltava-se para uma Antiguidade menos "respeitável" no século XVI, composta por obras de civilizações antigas com menor prestigio do que Grécia e Roma, tais como os escritos mágico-astrológicos de egípcios, caldeus, persas e hebreus ${ }^{10}$.

No momento de sua vida em que circulou pela Península Itálica, Agrippa seguiu seus estudos de ocultismo antigo, tendo contato e sendo influenciado também pelos pensadores neoplatônicos de Florença, o que lhe permitiu certa aproximação com uma linha do Humanismo considerada mais legítima e erudita, que podia garantir alguma afinidade do seu trabalho com o padrão mais socialmente aceito da filosofia renascentista. A necessidade de se adaptar a situações de perseguições sociais movidas pela sua posição filosófica de defesa da magia favoreceu uma busca constante por respeitabilidade intelectual em partes distintas da Europa de sua época.

A trajetória de vida de Agrippa foi marcada por migrações voltadas a sua inserção em cortes e círculos intelectuais que lhe garantissem uma vida confortável e visibilidade social em uma Europa que de alguma maneira mantinha-se reticente aos elementos extravagantes da magia e da arte do oculto. A entrada na sociedade letrada e nobre era sempre iniciada por seu conhecimento em medicina, chegando a conquistar, em 1524, o cargo de médico pessoal de Luisa de Sabóia, mãe do rei Francisco I da

\footnotetext{
10 "Agrippa provides a clear demonstration that the eagerness of Renaissance humanists to recover the works of the ancients included not only authors regarded as "respectable" by modern classical scholars but also a vast body of ancient (or pseudo-ancient) texts that claimed to offer wisdom going back to the very origins of human civilization, the so-called "ancient theology" (prisca theologia), such as the Hermetic texts from ancient Egypt, the Chaldean Oracles and writings of Zoroaster from Mesopotamia and Persia, the teachings attributed to Pythagoras and supposedly passed on from him to Plato and his followers the Platonists, and the secret Jewish books known as Cabala, which claimed to present the full meaning of the Hebrew Scriptures concealed beneath the words of the text." Charles Nauert, "Heinrich Cornelius Agrippa von Nettesheim", The Stanford Encyclopedia of Philosophy (Summer 2011 Edition), Edward N. Zalta (ed.). http://plato.stanford.edu/archives/sum2011/entries/agrippa-nettesheim
} 
França. A partir de sua notoriedade como perito em medicina, Agrippa seduzia alguns integrantes das cortes que frequentava, com seu domínio sobre os temas da alquimia e da astrologia. Não somente membros das famílias reais, mas grandes banqueiros e altos funcionários de governo também foram atraídos por suas narrativas sobre seres elementares, poderes cabalísticos e a influência dos astros sobre a vida humana.

Entretanto, como parte da formação de um notório scaltrito, Agrippa tinha convicções consideradas perigosas por determinados setores da sociedade cristã europeia do século XVI. Por manter posições próximas aos reformadores cristãos humanistas, como Erasmo de Roterdã e Jacques Lefèvre d'Étaples, Agrippa entrou em enfrentamento direto com frades mendicantes e inquisidores dominicanos, o que lhe causou problemas consideráveis. A recusa de suas ideias por inimigos poderosos, como os religiosos conservadores e a crise econômica que afetou seus padrinhos franceses em 1526, durante a Guerra dos Quatro $\operatorname{Anos}^{11}$, fez com que a situação financeira de Agrippa se tornasse crítica. Nesse panorama de colapso econômico e social, o polemista alemão elaborou seu segundo livro, De incertitudine et vanitate scientiarum et artium.

A criação de um texto que contradizia sua obra anterior, De occulta philosophia libri tres, pode ser entendida como uma tentativa astuciosa que combinava a transformação de suas convicções pessoais com a necessidade de voltar a frequentar espaços sociais privilegiados. A mudança de Agrippa é tão ardilosa que, após anos sob a tutela da monarquia francesa, ele se transfere para o território Habsburgo com o intuito de, então, conquistar os favores dos rivais que levaram a França à derrota militar e à crise econômica. O defensor aguerrido do domínio do homem sobre a natureza por meio da magia refutava qualquer certeza filosófico-metafísica. $\mathrm{O}$ fiel membro da corte e médico de figuras proeminentes da França de Francisco I passou a ser uma figura que buscava posição social na Antuérpia, território dos principais rivais dos franceses, os Habsburgo.

À revelia das simpatias políticas e econômicas de Agrippa, o caráter incerto de suas ideias é mais oportuno quando se analisa o debate epistemológico suscitado por suas duas obras principais. De modo geral, ele teve como objetivo comum a seus textos a refutação de tradições medievais incompatíveis com o conhecimento da Antiguidade

\footnotetext{
${ }^{11}$ Conflito que envolveu diretamente duas das maiores potências imperiais da Europa do século XVI: de um lado, Francisco I da França aliado à República de Veneza; do outro, uma coalizão liderada por Carlos I da Espanha (ou Carlos V de Habsburgo), imperador do Sacro Império Romano Germânico, ao lado de Henrique VIII da Inglaterra e dos Estados Pontifícios. A guerra teve fim com o Tratado de Madri, em 1526, quando a França foi vencida após a Batalha de Pavia.
} 
revisitado pelo Humanismo no Renascimento. Em De occulta philosophia libri tres, por exemplo, é visível a influência, sobretudo, de Marsilio Ficino, Giovanni Pico della Mirandola e da cabala judaica cristianizada, de Johann Reuchlin ${ }^{12}$. Nesse sentido, Agrippa somou à sua percepção de figuras notórias do Humanismo o resgate de trabalhos como os escritos metafísicos dos árabes medievais da Falsafa (الفلسفة) Esse processo retórico permitiu que sua obra De occulta philosophia libri tres tornasse a magia em um conhecimento legítimo estruturado por padrões e conceitos filosóficos, com o intuito de beneficiar a humanidade. O problema dessa intenção transformadora do mundo sustentada por Agrippa é que ela transmite a ideia de que o conhecimento das ciências ocultas é um poder potencialmente perigoso e não pode cair nas mãos de indivíduos moralmente questionáveis. Por essa razão, Agrippa recorreu a enigmas e linguagens cifradas para elaborar o seu texto, uma espécie de "dispersa intentio" (sentido disperso), que somente um homem sábio poderia alcançar. Nesse caso, a incerteza foi utilizada como uma ferramenta retórica para restringir o acesso à magia, e, portanto, aos poderes circunscritos a um autêntico scaltrito das letras.

A lógica argumentativa das ciências ocultas de Agrippa se fundamenta em uma visão hierárquica do mundo, organizado em domínios distintos como o elementar (material), o celestial (matemático-astrológico) e o intelectual (espiritual, de criaturas mágico-religiosas). Para ele, a conexão entre esses três domínios garante a harmonia do mundo e o espaço conjunto em que Deus atua e exerce o seu poder a partir do domínio mais elevado (o intelectual) em direção ao menos considerado (o elementar).

Um dos pontos de inter-relação entre essas três ordens do mundo é a presença comum dos quatro elementos da ciência antiga: água, fogo, terra e ar. Parte dessa crença

\footnotetext{
12 "Agrippa aimed to bring about a renewal of religion, culture, and society through rejection of false, oppressive medieval traditions and authorities and through recovery of a heritage of (supposedly) ancient wisdom that included occult texts not much emphasized in the early Italian Renaissance but increasingly influential from the beginning of Marsilio Ficino's work as a translator in the 1460's. This goal is evident in both the early manuscript (1510) and the vastly expanded printed edition (1533) of De occulta philosophia. Yet it is also evident in shorter works like De triplici ratione cognoscendi Deum / On Three Ways of Knowing God, De originali peccato/ On Original Sin, and Dialogus de homine/ A Dialogue on Man, all of them composed in Italy about 1515-16, and in various lectures, most of which also come from his years in Italy (1511-18). These works reflect influence by the Florentine philosophers Marsilio Ficino (1433-99) and Giovanni Pico della Mirandola (1464-94), as well as by the Hermetic treatises first translated from Greek by Ficino and the supposedly ancient (but largely medieval) tracts of Jewish Cabala, especially as interpreted in the Christianized Cabala of the German humanist Johann Reuchlin." Charles Nauert. Op. cit.

13 "Foi a falsafa que se encarregou de fazer com que os princípios filosóficos se deparassem, pela primeira vez, com os dogmas da religião islâmica, o que foi sem dúvida um novo desafio para ambas. A falsafa foi a responsável não só pela imersão do pensamento da filosofia grega entre os árabes mas também pela transmissão da filosofia grega para o Ocidente." Miguel Attie Filho. Falsafa: a filosofia entre os árabes - uma herança esquecida. São Paulo: Palas Athena, 2002. p. 33.
} 
de Agrippa na composição natural do mundo pelos quatro elementos é uma herança da Antiguidade Clássica e do pensamento medieval árabe-islâmico, principalmente das teorias médicas de Hipócrates, Aristóteles, Galeno de Pérgamo, al-Rāzi e Avicena. Em poucas palavras, essa tradição médica defendia que a composição física do corpo humano era formada por partes que apresentavam porções distintas desses quatro elementos, e a cada um deles correspondia uma das quatro propriedades naturais: à água pertencia o frio; ao fogo o calor, à terra a secura, e ao ar a umidade. A relação entre os componentes elementares da matéria e suas propriedades estava também conectada aos quatro humores da teoria médica de Hipócrates: a linfa, a bílis amarela, a bílis negra e o sangue, e, a cada humor, correspondia um órgão humano ${ }^{14}$ :

Os quatro elementos na medicina humoral:

\begin{tabular}{|c|c|c|c|c|}
\hline & Água & Fogo & Terra & Ar \\
\hline Propriedades & Frio & Calor & Aridez & Umidade \\
\hline Humores & $\begin{array}{c}\text { Linfa ou } \\
\text { fleuma }\end{array}$ & Bílis amarela & Bílis negra & Sangue \\
\hline $\begin{array}{c}\text { Órgão } \\
\text { humano }\end{array}$ & Cérebro & Fígado & Baço & Coração \\
\hline
\end{tabular}

A importância da teoria médica dos humores e do conhecimento relacionado aos quatro elementos era um dos pontos de aproximação da medicina com a astrologia e as ciências ocultas no texto de Agrippa. As proporções harmoniosas entre água, fogo, terra e ar esclareciam grande parte dos fenômenos naturais e retoricamente serviam para a análise do movimento e organização dos astros, formando uma base de informações que estruturavam a narrativa sobre o mundo celeste. Entretanto, a magia como conhecimento baseado na experiência necessitava de um quinto elemento capaz de elucidar as propriedades naturais ainda desconhecidas pelo homem do século XVI. Esses fenômenos de explicação oculta precisavam desse quinto elemento, ou spiritus mundi, para serem justificados, já que a razão humana não era capaz de alcançar diretamente o entendimento dessas questões. O ofício do alquimista se fundamentava no controle desse conhecimento oculto e inalcançável aos demais estudiosos.

\footnotetext{
${ }^{14}$ De acordo com a teoria humoral de Hipócrates e Galeno, para o predomínio de cada humor em um indivíduo correspondia um tipo fisiológico: fleumático, colérico, melancólico e sanguíneo.
} 
A virada no argumento de Agrippa após o colapso pessoal e financeiro vivido nos anos de crise na França se firma na perspectiva de radicalização de seu conceito de incerteza. Para ele, todos os sistemas de pensamento produzidos pelo homem são imprecisos, e sua obra De incertitudine et vanitate scientiarum et artium é a defesa pública dessa posição. Como é possível justificar uma mudança tão profunda de posicionamento filosófico? Acreditar em uma recusa contumaz motivada pela desesperança individual do autor é uma saída ilusória. A constatação de que Agrippa não abandonou as leituras e estudos de tratados mágicos após a publicação da obra $D e$ incertitudine et vanitate scientiarum et artium impõe a necessidade de se encontrar outra explicação que torne compatível a produção de ambos os textos citados ${ }^{15}$.

A alternativa mais razoável é a de que a refutação de seu texto sobre as ciências ocultas foi uma imposição das circunstâncias sociais, não necessariamente movida pela crise financeira, mas, em especial, pela perseguição e recusa que inquisidores e membros influentes da Igreja Católica destinavam à magia de Agrippa. Um argumento que reforça essa possibilidade é o fato de que a ordem de publicação dos dois textos é inversa à elaboração, já que De occulta philosophia libri tres foi concluído em torno de 1510 e publicado em 1533, enquanto que a obra crítica De incertitudine et vanitate scientiarum et artium foi finalizada em 1526 e publicada em 1530.

A possível contradição entre a defesa da magia e a defesa do ceticismo em duas obras distintas se justifica, assim, por força das circunstâncias. Agrippa não deixa de ser o alquimista incisivo revelado em sua De occulta philosophia libri tres; por questões de sobrevivência social, permitiu-se publicar a refutação antes da afirmação de suas ideias, como um astuto homem do século XVI que utilizava a incerteza e a imprecisão como parte de sua condição de scaltrito.

As ciências ocultas podiam até sugerir, por seu caráter científico marginal, no século XVI, uma propensão de seus estudos ao estilo de pensamento astuto que se identificou nas obras de Agrippa, mas, mesmo na matemática, especificamente no conhecimento algébrico, o manejo sistemático de operações numéricas para revelar resultados incógnitos também admite uma organização do pensamento dependente das

\footnotetext{
15 "The apparent incompatibility between these two major books- that is, the problem of the unity of Agrippa's thought — cannot be solved by assuming that he simply changed his mind about occult sciences, since he not only continued to study and seek out books on the occult arts at every stage of his life, including the years (1526-30) when he wrote and revised De vanitate, but also continued to rework De occulta philosophia right down to publication of the revised version in 1533. De vanitate, the book that seems to retract his work on occult philosophy, was written second but published first (1530); and then, three years later, the book on magic came out, after a fierce struggle by Agrippa to overcome the attempt of a Dominican inquisitor to block its publication." Charles Nauert. Op. cit.
} 
noções de incerteza e imprecisão. Dentre os trabalhos sobre álgebra que se enquadram nesse contexto do século XVI está Artis Magnae Sive de Regulis Algebraicis (A grande arte, ou as regras da álgebra), de Girolamo Cardano, nova obra aqui relacionada para ilustrar a perspectiva astuta garantidora da sobrevivencia dos autores em momentos de crise social.

Assim como no caso de Agrippa, a biografia de Cardano é significativa para se compreender o sentido scaltrito de sua principal obra. Nascido em 1501 e filho de uma relação socialmente renegada entre Chiara Micheri, uma viúva que engravidou por acidente, e Fazio Cardano, médico, ocultista e matemático de porte físico caracterizado pelos ombros curvados e pela gagueira, Girolamo Cardano nasceu quase morto, e teve que ser submetido ao inusitado procedimento médico de ser lavado com vinho quente para sobreviver. Ao longo de sua infância, outros banhos "curadores" garantiram a saúde do pequeno Cardano, como, por exemplo, o banho de vinagre quente a que foi submetido durante uma epidemia de peste que afligiu parte da Itália, matando alguns de seus irmãos e sua ama de leite.

A infância de Cardano foi difícil, não somente porque os recursos financeiros da família eram escassos, mas também porque a saúde frágil colocava sua vida frequentemente em risco. Os estigmas que lhe foram atribuídos na infância, por ser fruto de uma relação originalmente ilegítima e de saúde frágil, somente começaram a ser revistos no momento em que Cardano passou a estudar medicina, aos 19 anos. Quando as doenças já eram uma questão superada, a Guerra dos Quatro Anos ${ }^{16}$ trouxe $^{2}$ novamente a instabilidade que se pensava vencida. A família Cardano parecia marcada pela penúria, já que mesmo mudando-se de Pávia para Veneza e assumindo importantes cargos universitários, sua situação econômica não era compatível com os gastos inerentes à posição social exigida de um acadêmico. A saída encontrada por Cardano foi a prática de uma atividade muito pertinente a um scaltrito: a jogatina em mesas de apostas com baralhos e toda a sorte de jogos de azar. ${ }^{17}$

É evidente que esse estilo de vida inzoneiro era resultado de certo flerte de Cardano com as questões incógnitas da ação do acaso e das viradas de sorte que a

\footnotetext{
${ }^{16}$ Ver nota 10.

17 "Para sustentar-se, Cardano lançou mão de uma paixão antiga e irrefreável: o jogo de azar. Baralho, dados, xadrez foram, durante um período, sua maior fonte de renda, mas, ao longo dos anos - de muitos anos -, tudo isso se tornaria, na realidade, a causa de muitos reveses patrimoniais: 'Assim dilapidei ao mesmo tempo minha reputação, meu tempo e meu dinheiro', lamentaria mais tarde, com amargura, o próprio Gerolamo, já no outono de sua vida." A fórmula secreta: Tartaglia, Cardano e o duelo matemático que inflamou a Itália da Renascença. Campinas: Editora UNICAMP, 2012. p. 117.
} 
trajetória de um indivíduo pode experimentar. Nesse aspecto, Cardano dedicou parte considerável de sua vida à tentativa de controlar as forças ocultas e adivinhatórias que pensava existir, e de ser uma espécie de intérprete das mesmas. Cardano acreditava ter a capacidade de prever o futuro por meio de sonhos e de se comunicar com demônios, algo normal para uma época em que as fronteiras entre ciência e magia ainda estavam sendo construídas.

Do ponto de vista prático, a excentricidade de Cardano não garantia a solução de seus problemas mais imediatos, o que o obrigou a retomar com seriedade sua carreira de médico. Aproximou-se do diplomata milanês Filippo Archinto e, por seu intermédio, conseguiu boa remuneração e prestígio como professor de astronomia e matemática, além do exercício da medicina.

A ascensão social conquistada por Cardano com a propagação de seus méritos como médico lhe garantiu algumas inimizades. Ele chegou a escrever um polêmico tratado crítico sobre a atuação dos médicos de sua época, em 1536, o De malo recentiorum medicorum usu medendi libellus (Panfleto sobre o mau uso da medicina por parte dos médicos de hoje), provocando a ira de alguns colegas de profissão diretamente afetados pelo texto e, em contrapartida, o aumento de sua reputação.

Porém, o reconhecimento pelo trabalho reflexivo de Cardano foi causado por sua obra de 1545, a Artis Magna Sive de Regulis Algebraicis. Esse texto começou a ser escrito em fins da década de 1530, com o propóstio de ser um grande tratado sobre a teoria das equações algébricas de primeiro e segundo graus; mas, após entrar em contato com outros matemáticos de sua época que também se preocupavam com as questões da álgebra, Cardano reuniu o conhecimento produzido por diferentes estudiosos, aperfeiçoou esses cálculos e publicou capítulos sobre a resolução de equações cúbicas e quadráticas em sua obra.

A solução de equações cúbicas era o grande tema a ser desvendado pela álgebra do século XVI. A fórmula secreta para se resolverem esses problemas não foi fruto do empenho exclusivo de um único matemático. Ao longo da segunda metade do século XV e a primeira metade do século XVI, alguns matemáticos dedicavam seu tempo ao desafio de encontrar uma fórmula geral para a solução de equações cúbicas, e, antes de Cardano, esse esforço envolveu homens como Scipione del Ferro, Antonio Maria Fior e Niccolò Tartaglia.

A quantidade variada de homens que se concentraram no estudo da álgebra mostra a grande receptividade que esse tipo de pensamento possuía no século XVI. A 
reflexão filosófica sobre modos operativos de se lidar com a incerteza e a imprecisão favoreceu o desenvolvimento da resolução de incógnitas matemáticas pela álgebra e também transferiu esse trato técnico-analógico próprio do mundo das equações matemáticas para o mundo das ideias.

Em poucas palavras, a corrida pelo mérito de ser o matemático responsável pela elaboração de uma fórmula geral para equações de terceiro grau envolveu diretamente Cardano e Tartaglia ${ }^{18}$. Entre acusações de traição e plágio, já que teria sido Tartaglia quem ensinou a Cardano a "fórmula secreta", o método de resolução das equações de terceiro grau foi publicado em Artis Magna Sive de Regulis Algebraicis, e os méritos da façanha matemática foram atribuídos inicialmente a Cardano.

O que se pode aprender com a vida e as ideias desse scaltrito matemático chamado Girolamo Cardano é que a roda da Fortuna sempre reserva imprevistos e incertezas a quem a desafia. Os reconhecimentos por seu trabalho não garantiram a Cardano a estabilidade que tanto buscou ao longo de sua vida. Foi preciso um pouco mais de astúcia para que o algebrista scaltrito não tivesse suas expectativas reduzidas à infâmia. O motivo que levou Cardano ao infortúnio está contido em uma tela do pintor espanhol Luis de Morales, intitulada La Sagrada Familia:

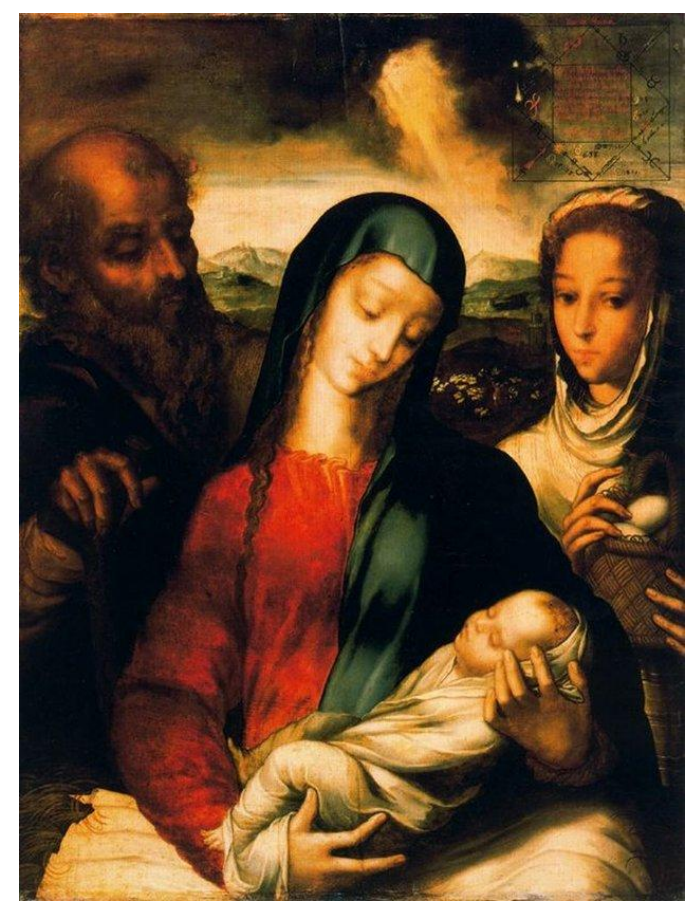

\footnotetext{
${ }^{18}$ Para informações sobre essa disputa ver o capítulo 3 deste trabalho.
} 
Essa tela foi elaborada entre 1562 e 1569 e possui uma curiosidade que trouxe problemas a Cardano em uma época em que a Contrarreforma ja havia traçado suas diretrizes religiosas conservadoras, após o Concílio de Trento. Em seu canto direito superior, a tela de Morales apresenta um diagrama semelhante ao horóscopo de Jesus Cristo elaborado por Cardano, em 1554. A perigosa junção entre arte devota e astrologia em uma época de perseguição a traços de reforma e inovação da fé católica colocou sob suspeita as atividades do autor de uma espécie de mapa astral de Jesus. A comparação entre o diagrama da tela de Luis de Morales e a publicação de Cardano não deixa dúvidas:
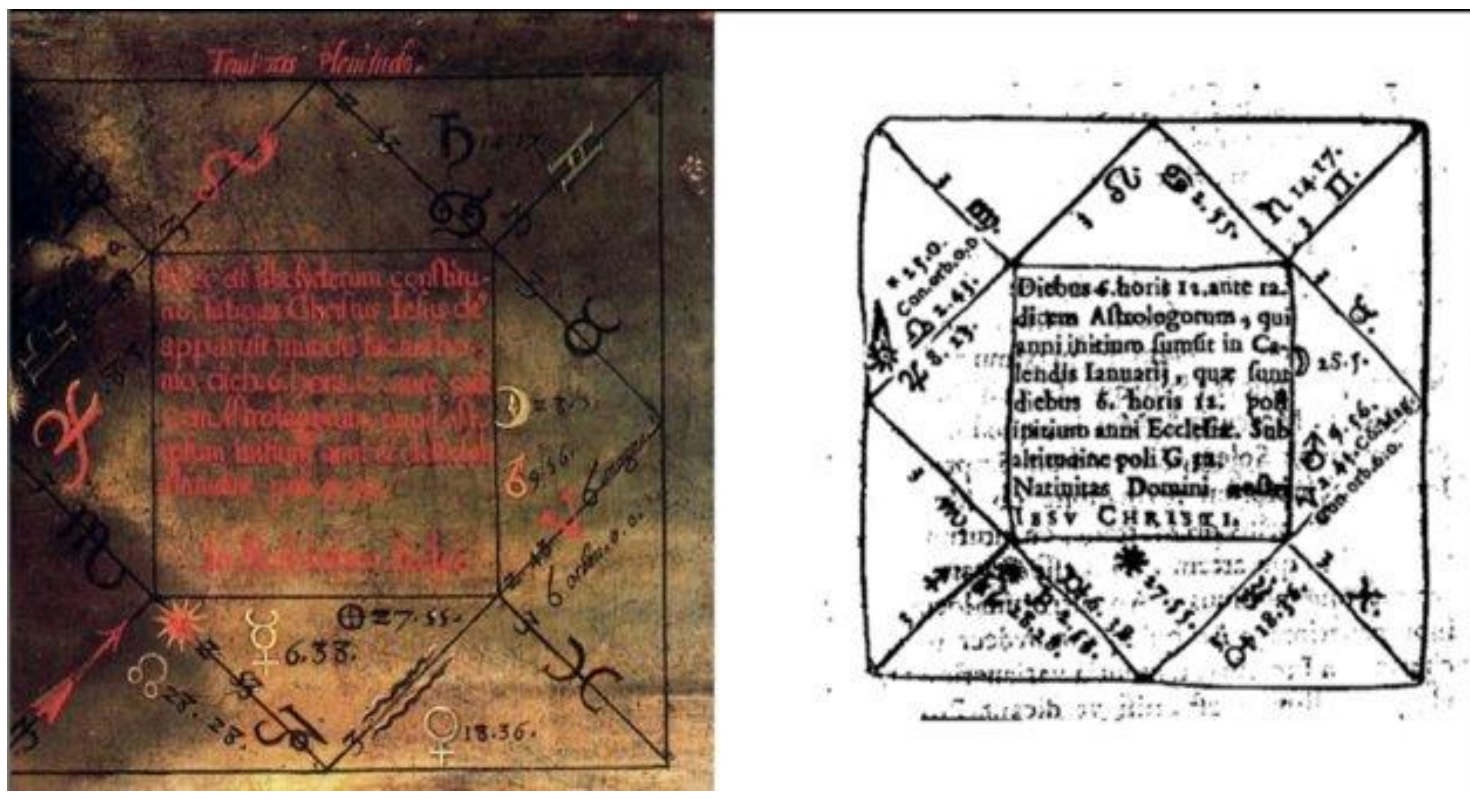

O resultado dessa aproximação suspeita deu visibilidade à face de Cardano considerada inapropriada a um grande mestre da álgebra. Em 1570, o Tribunal da Santa Inquisição de Bolonha o condenou à prisão, retirando seu direito de publicar novos trabalhos ${ }^{19}$.

O caráter astuto de valorização da perspectiva reflexiva da incógnita mostrou-se mais evidente no obra de Cardano destinada à álgebra, Artis Magnce Sive de Regulis Algebraicis. Os anos de dedicação à tarefa de encontrar a fórmula geral de resolução das equações cúbicas permitiram que a habilidade de organizar e encontrar resultados fosse

\footnotetext{
19 "A vida não era fácil para Cardano. Seu filho favorito foi executado em 1560 por ter envenenado a esposa. Em 1570, Cardano foi acusado de heresia e ficou preso por vários meses por calcular o horóscopo de Jesus Cristo. Como consequência, ele perdeu sua cadeira de professor em Bolonha e o direito de publicar livros. Ele morreu no dia em que havia previsto, mas ele pode ter ajudado a profecia a se cumprir cometendo suicídio." Anne Rooney. A História da matemática: desde a criação das pirâmides até a exploração do infinito. São Paulo: M. Books, 2012. p. 137.
} 
transposta para a maneira como ele decidia as vicissitudes da vida e para a disposição reflexiva de buscar variáveis resolutivas em situações de crise, imprecisão e incerteza. Nesse sentido, o tratado sobre a álgebra foi também um esboço da estruturação do pensamento filosófico de Cardano, tentando desvendar aquilo que é oculto na vida, dando visibilidade ao incerto.

A última obra do século XVI aqui exposta, que delimita a forma de agir e pensar sobre o mundo por meio da condição de scaltrito é Della descrittione dell'Africa et delle cose notabli che ivi sono, ou, simplesmente, Descrittione dell'Africa, de João Leão Africano $^{20}$. A vida desse viajante foi cercada de reveses que o fizeram assumir distintos papeis sociais, negociando sua sobrevivência no interior das conturbadas relações políticas e econômicas da região do Mediterrâneo nesse período.

A narrativa sobre a vida de João Leão Africano favoreceu sua mitificação como uma espécie de homem do seu tempo. Nascido al-Hasan ibn Muhammad al-Wazzan alFasi (حسن ابن محمد الوزان الفاسي), o viajante granadino mudou-se para a região do Marrocos por decisão de seus pais, que fugiam da situação perigosa em que viviam os muçulmanos de Granada após a invasão cristã espanhola de 1492. O próprio governador muçulmano da cidade, Boabdil, imigrou em 1493, o que reforça a impressão de que a família de al-Hasan ibn Muhammad al-Wazzan al-Fasi seguiu o exemplo de outras famílias importantes de Granada.

Ainda que inicialmente os governantes cristãos tivessem prometido tolerar a fé islâmica na cidade, a nova conjuntura social e o medo de uma onda de apostasia levaram muitos muçulmanos a deixar a Península Ibérica em fins do século XV. A pressão para a conversão forçada em Granada somente ganhou força em 1499, quando Francisco Jiménez de Cisneros (Confessor Real, Arcebispo de Toledo, Cardeal e Primado de España) passou a interferir na cidade. Jiménez de Cisneros foi imprescindível para a aplicação da Pragmática de 11 de fevereiro de 1502, em que os reis espanhóis instituíam a obrigatoriedade do batismo aos muçulmanos ou a sua expulsão.

\footnotetext{
${ }^{20}$ Giovan Lioni Africano, o autor de Della descrittione dell'Africa et delle cose notabli che ivi sono. Existem outros registros possíveis para referir-se a essa figura, tais como a versão em latim Leo Africanus, ou seu nome em árabe antes da conversão ao catolicismo: al-Hasan ibn Muhammad al-Wazzan al-Fasi. Neste trabalho ele será citado como al-Hasan ibn Muhammad al-Wazzan al-Fasi até sua conversão ao cristianismo; João Leão de Medici, nome de batismo (ver nota 24); João Leão Africano, ou apenas Leão Africano, como ele ficou conhecido após a publicação da referida obra por Giambattista Ramusio.
} 
Já estabelecido em Fez no nascer do século XVI, al-Hasan ibn Muhammad alWazzan al-Fasi recebeu uma sólida educação na Universidade Islâmica de alQarawiyyin, embora os registros de egressos de al-Qarawiyyin não mostrem o seu nome. A partir desse momento, João Leão Africano realizou várias missões comerciais e diplomáticas para o soberano de Fez, dentre outros soberanos locais, além de viagens pessoais por grande parte do mundo islâmico moderno. Uma das mais importantes teria sido a longa jornada que empreendeu para Constantinopla, Beirute e Bagdá entre 1507 e 1508, possivelmente com 14 anos de idade ${ }^{21}$.

Em 1518, quando voltava de uma peregrinação à Meca, foi capturado no mar Mediterrâneo por piratas sicilianos, possivelmente nas proximidades de Djerba, uma ilha no Sul da costa da atual Tunísia ${ }^{22}$. Levado à Nápoles para ser vendido como escravo, a Fortuna o conduziu para Roma, e foi entregue como presente ao Papa Leão X, Giovanni di Lorenzo de Medici.

No período em que viveu em Roma, foi mantido prisioneiro no Castelo de Santo Ângelo, e uma das regalias que lhe foram confiadas foi a de ter acesso ao acervo em árabe da Biblioteca Apostólica Vaticana, o que permitiu a al-Hasan ibn Muhammad alWazzan al-Fasi circular pelo castelo e conversar com funcionários, soldados e outros prisioneiros, melhorando rotineiramente sua capacidade de comunicação em italiano vulgar e latim. Não tardou muito para que o ilustre cativo adquirisse importantes interlocutores, como os clérigos e o próprio Papa Leão X, mesmo porque o acesso à uma figura cuja família era reconhecida pelas generosas práticas de mecenato não seria um desafio intransponível para o scaltrito al-Hasan ibn Muhammad al-Wazzan al-Fasi.

A política do Papa frente ao Islã era notória. Leão X não media esforços para oficializar o velho plano de conversão de todos os muçulmanos ao cristianismo, inclusive pela força das armas e das negociações diplomáticas. No mesmo ano da captura e chegada de al-Hasan ibn Muhammad al-Wazzan al-Fasi à Roma, o Papa enviou quatro cardeais às cortes da Inglaterra, França, Espanha e do Sacro Império

\footnotetext{
21 "In 1507-1508, al-Hasan b. Muhammas, who was then perhaps merely fourteen years old, is said to have performed the first of his great voyages, visiting Constantinople, Beirut and Baghdad. We do not know his reason for undertaking such a long journey to the eastern Mediterranean and the Middle East if he ever did. The historicity of this adventure rests on Leo's obscure remark in his work." Idem, ibidem, p. 118.

22 "His editor Ramusio and Orientalist scholars later said that it had been off the Tunisian island Djerba, a reasonable stop in an itinerary from Cairo to Fez; a papal secretary said it had been hundreds of miles farther east near Rhodes. Venetian observers reported that Boabdilla had taken over a Ragusan ship with '60 turks' on board in June 1518, and perhaps al-Wazzan was one of the 'Turks". Natalie Zemon Davis. Trickster Travels: A Sixteenth-Century Muslim between Worlds. New York: Hill and Wang, 2006. p. 55.
} 
Romano Germânico ${ }^{23}$, solicitando uma trégua de cinco anos entre os reinos cristãos para a efetivação de uma cruzada contra os turcos.

O enfrentamento direto entre os reinos europeus unidos e o Império otomano jamais ocorreu, mas, se não havia como suscitar a conversão generalizada dos muçulmanos ao cristianismo, o Papa Leão X pôde ao menos promovê-la em sua própria corte, quando, entre 1519 e 1520, levou al-Hasan ibn Muhammad al-Wazzan al-Fasi ao batismo e ao catecismo, envolvendo nesse processo homens de confiança como Paride Grassi (mestre de cerimônias e bispo de Pesaro), Gabriel Fosco (arcebispo de Durazzo), e Giovanni Battista Bonciani (bispo de Caserta).

Não há dúvidas de que al-Hasan ibn Muhammad al-Wazzan al-Fasi foi batizado à força. Sobre esse episódio, Natalie Zemon Davis afirma que "al-Wazzan `s eventual decision to say that he believed the articles of the Christian Faith was in part coerced: continued imprisonment and/or enslavement would have been his destiny otherwise. ${ }^{24,}$ Os padrinhos de batismo não poderiam ser mais representativos sobre como seria a vida desse scaltrito e suas missões futuras, não mais como al-Hasan ibn Muhammad alWazzan al-Fasi, mas a partir de então como Joannes Leo de Medicis, seu nome "cristão ${ }^{25 ": ~ B e r n a r d i n o ~ L o p e z ~ C a r v a j a l ~(P a t r i a r c a ~ d e ~ J e r u s a l e ́ m), ~ L o r e n z o ~ P u c c i ~}$ (Cardeal e conhecido como negociador de indulgências), e Egidio Viterbo (Cardeal e filósofo humanista).

Os anos seguintes à conversão foram marcados por intensos trabalhos como erudito, tradutor e professor de árabe. Os dados sobre a vida do então João Leão de Medici são escassos. Não existem muitas fontes que documentam fielmente os seus passos como um cristão livre na corte do Papa Leão X. O que se pode afirmar é que o projeto de ampliação da fé católica nos territórios muçulmanos do sultão otomano transformou João Leão de Medici em uma fonte de informação preciosa para o Papa.

De maneira indiciária, pode-se considerar que sua obra Della descrittione dell'Africa et delle cose notabli che ivi sono foi fruto desse projeto papal, já que, mesmo antes do término desse texto, o converso granadino serviu como informante do Papa sobre territórios africanos. Um exemplo dessa função de João Leão de Medici aparece quando Natalie Zemon Davis sugere que o mesmo foi consultado pelo Papa sobre a

\footnotetext{
${ }^{23}$ Em 1518, o Sacro Império Romano Germânico e a Espanha ainda não tinham sido unificados. Essa integração dinástica ocorreu no ano seguinte, com a morte de Maximiliano I e a reunião dos tronos em favor de Carlos I da Espanha (posteriormente Carlos V do Sacro Império).

${ }^{24}$ Natalie Zemon Davis. Op.cit. p. 63.

${ }^{25} \mathrm{O}$ granadino batizado nunca utilizou o sobrenome "Medici". Sempre privilegiou o uso do nome "João Leão"; posteriormente, receberia o apodo "Africano".
} 
Etiópia, já que em 1521 chegou ao Vaticano uma carta do rei de Portugal, D. Manuel I, com noticias sobre a ida dos lusitanos ao reino cristão de Prestes João, nessa localidade ${ }^{26}$. Como não existem registros exatos de quando a citada obra começou a ser escrita, pode-se deduzir que esse tipo de documento informativo servia aos interesses políticos, religiosos, culturais e comerciais do Papa Leão X.

A data de comprometimento de João Leão de Medici com esse projeto papal pode ser relacionada ao ano de 1521, tanto pelo uso de informações sobre a Etiópia quanto pelo fato de que dezembro desse ano é a data de morte do Papa Leão X. O que se passou com João Leão de Medici após a morte de seu protetor, pouco se sabe. Circulou por Bolonha e Roma nos anos seguintes, dedicando-se à produção de diversas obras. Nesse período, seu relato sobre a África foi sendo elaborado, até que, entre 1526 e 1528, Della descrittione dell'Africa et delle cose notabli che ivi sono foi finalizado.

Sobre a trajetória do autor, sabe-se que exerceu também sua condição de viajante, até que, de acordo com Egidio de Viterbo e alguns analistas de sua vida, conseguiu voltar à África, retomando a fé muçulmana e vivendo seus últimos dias na região da Tunísia ${ }^{27}$.

O produto da astúcia de uma vida cambaleante entre mundos, religiões, continentes, idiomas e linguagens foi a obra Della descrittione dell'Africa et delle cose notabli che ivi sono, em suas mais variadas formas, publicações, republicações e traduções. Na tese a ser apresentada aqui, a base do texto analisado e traduzido foi a que se encontra disponível na Biblioteca Italiana Università degli Studi di Roma "La Sapienza ${ }^{28,}$, sempre em comparação com a obra editada em italiano pelo geógrafo veneziano Giovanni Battista Ramusio, em 1550, no interior de uma recopilação de textos geográficos intitulada Delle Navigationi et viaggi. É a partir da versão de Ramusio que o João Leão de Medici passa a ser identificado como João Leão Africano,

\footnotetext{
26، In the summer of 1521, Leo X may also have turned to Giovanni Leone for information about Ethiopia. A letter had arrived from King Manuel of Portugal with the triumphant news that the Christian kingdom of the wondrous Prester John, which Europeans had sought for centuries in the East, had been found by Portuguese captains in Ethiopia." Natalie Zemon Davis. Op. cit. p. 68.

27 "Al final del Libro VIII desvela su intención de regresar al África donde espera rematar la redacción del relato de sus viajes. No obstante, en el prefacio de la edición italiana de 1588 se asegura que León habría fallecido poco antes de 1550 en Roma, información no corroborada por otras fuentes, ni presente en las primeras ediciones de Ramusio, cuando éste vivía. J. A. Widmanstatter en su prólogo a los Evangelia syriaca atestigua que retornó a Túnez, donde se habría reintegrado a la fe islámica y cita como informador a Egidio de Viterbo. Este solo testimonio basta a O. Zhiri para afirmar de modo contundente que regresó al África, aunque sí podamos convenir en que con posterioridad a esa fecha ya no haya más noticias sobre él." Serafin Fanjul (tradutor). Descripción General del África y de las Cosas Peregrinas que allí hay. Granada: Fundación El Legado Andalusí. 2004. p. 57.

${ }^{28} \mathrm{http}: / /$ www.bibliotecaitaliana.it/xtf/view?docId=bibit001323/bibit001323.xml\&chunk.id=d6313e120\&t oc.id=d6313e120\&brand=default
} 
o nome mais frequentemente atribuído ao autor do texto Della descrittione dell'Africa et delle cose notabli che ivi sono.

O exemplar da obra de Ramusio aqui trabalhado é um fac-símile de uma edição de 1837, com algumas variações em comparação ao texto da Biblioteca Italiana. Na tradução apresentada ao final desta tese, em caso de disparidade entre as duas versões trabalhadas, buscou-se o cotejo com outras traduções elaboradas em outras línguas, como a versão espanhola de Serafin Fanjul, e a variante em francês disponível na Biblioteca Nacional Francesa.

O conteúdo do material traduzido nessa tese foi o "primeiro livro" da obra Della descrittione dell'Africa et delle cose notabli che ivi sono, que aborda os aspectos gerais do continente africano. Os outros livros que compõem a obra referem-se respectivamente: a) Sudoeste marroquino, b) Reino de Fez, c) Reino de Tremecen, d) as regiões de Bugia e Tunis, e) Sul dos atuais Marrocos, Argélia, Tunísia e Líbia, f) o chamado "País dos Negros", g) o Egito, e por fim, h) os rios, animais, vegetais e minerais africanos.

A escolha pela tradução do primeiro livro se justifica por diversos fatores. $\mathrm{O}$ mais relevante faz menção ao fato de que esse texto inicial versa sobre generalidades da África, e, por isso, é imprescindível para a definição do continente sustentada por Leão Africano. Além disso, a complexidade das informações apresentadas na obra e o cuidado com a escolha de termos para a tradução exigiram que os esforços dessa tese fossem concentrados nesse primeiro livro, mostrando que os limites epistemológicos de um texto acadêmico, com padrões científicos especificamente voltados a comprovações e análises dos argumentos do texto original, restringiriam a tradução a uma condição complementar à análise histórica, o que seria um descompasso em relação à magnitude da obra de Leão Africano.

Dessa forma, essa tese encontra-se dividida em cinco partes. O capítulo 1, intitulado "O século feito de fogo", apresenta as reflexões iniciais sobre a relação entre Europa latina e Norte da África mediada pelo Islã. O Objetivo desse capítulo é preparar a base contextual dos conflitos e aproximações entre os impérios europeus e os povos islâmicos ao longo do século XVI, com o intuito de inserir a trajetória pessoal de João Leão Africano nessa conjuntura própria da modernidade.

O capítulo 2, intitulado "O homem feito de terra", visa definir a experiência da viagem como um ambiente de interação entre Islã e Cristandade, recorrendo tanto às reflexões historiográficas sobre a literatura de viagem da Idade Moderna, quanto a 
definições teóricas do conceito de "tradução cultural" como experiência de tensão. Assim, a racionalidade humanista latina se faz presente no relato de João Leão Africano pela existência de uma contraposição entre as definições de Virtú e Fortuna próprias da leitura moderna de obras da Antiguidade Clássica que caracterizam o século XVI europeu.

Ao mesmo tempo, a partir do binômio "vergonha-honra", João Leão Africano recorre à sua leitura da tradição islâmica, analisando, pelo pudor, o comportamento dos povos encontrados, e organizando sua lógica de reflexão sobre o mundo a partir do conceito de incerteza presente na tradição islâmica de um "pensamento algébrico" que ganha força no século XVI.

No capítulo 3, intitulado "A África feita de água”, pode-se ver que para melhor justificar seu duplo olhar humanista latino-islâmico da África, João Leão Africano descreve a fluidez civilizacional do continente africano, mostrando como o comércio transforma as terras do Norte da África em ambiente de influência mútua entre o Islã e a Europa cristã. Dessa maneira, o viajante inventa uma visão sobre a África que é construída por uma "moral circulatória", expressa em descrições de mercadorias, peregrinações e atividades corsárias.

Por essa razão, a África passa a ser definida como um espaço de interstício entre Cristandade e Islã, o que reforça no século XVI o papel do comércio como ato constitutivo do trânsito cultural que insere a África na lógica da "colonialidade" do período, recorrendo a um vocabulário específico extraído do italiano vulgar.

Já no anexo 1 encontra-se a tradução inédita para o português ${ }^{29}$ do primeiro livro da obra Della descrittione dell'Africa et delle cose notabli che ivi sono, que trata das questões gerais da África criada por Leão Africano, conforme acima mencionado.

Por fim, o anexo 2 é composto pela versão original do citado livro, para servir como ferramenta de guia e comparação durante a leitura da tradução anteriormente exposta.

A alquimia e a matemática das palavras de Leão Africano começam, a partir daqui, a compor uma fórmula que deve, ao final, revelar que a tradução é uma forma de engano. Como o jogo de acasos que obrigou os homens do século XVI a negociarem a sobrevivência de suas vidas, toda a condição de scaltrito presente no viajante granadino e em sua obra acabam se transferindo para essa tese. Nas palavras de Leão Africano:

\footnotetext{
${ }^{29}$ Até o momento da elaboração dessa tese, as pesquisas não indicaram a existência de traduções da referida obra para a língua portuguesa.
} 
"Quero com isso inferir que, quando o homem vê vantagem para ele, sempre a persegue o quanto pode. Desse modo, onde os africanos sejam ofendidos, direi que nasci em Granada, e não na África; e quando minha terra for vituperada, invocarei a meu favor que fui criado na África, e não em Granada. Mas, agradeçam aos africanos minha atitude favorável de contar somente as coisas que são públicas e evidentes."

Por essa razão, nesta tese-scaltrito, “onde os historiadores sejam ofendidos, direi que me tornei tradutor... E quando a História for afrontada, invocarei a meu favor que fui um tradutor...". 


\section{O século feito de fogo}

Esse é meu polêmico pano de fundo. Não vejo o

Renascimento italiano como a chave para a modernidade e para o capitalismo. Isso me parece uma afirmação de europeus com tendências teleológicas.

(Jack Goody)

\subsection{O Renascimento em chamas}

O que uma pintura do século XVI pode revelar sobre a sua época? Os historiadores da arte e da cultura tentam responder essa questão com análises densas sobre aspectos técnicos da pintura como perspectiva, sombreamento, estilo, entre outros. No interior desse debate especializado, nem sempre acessível aos demais historiadores, encontra-se diluído um aspecto fundamental da pintura: a alma do artista.

Uma pintura não é somente uma referência técnica de um período estilístico; mais importante do que identificar a direção das pinceladas ou os produtos usados para conseguir determinado tom de púrpura, está a capacidade de se detectar as influências culturais que levaram o artista a escolher algo mais evidente: o tema, o cenário, as figuras e os símbolos que fazem dessa obra uma expressão de sua época.

A ideia de que uma tela pode ser, sobretudo, o reflexo das experiências vividas pelo artista permite que seja possível construir uma história cultural menos técnica e mais sensível, valorizando uma pintura pela sua capacidade de ser uma sinédoque das interações culturais de uma época através da vida de um pintor. Nesse sentido, o século XVI serve como inspiração para esse exercício interpretativo. Basta escolher um artista pouco enaltecido pela historiografia da arte canônica e interpretar sua obra maestra.

Esse é o caso de Fernando Yáñez de la Almedina (1475 - 1536). Legítimo representante da pintura renascentista espanhola, Fernando Yáñez não é um total desconhecido, nem, muito menos, um ícone da genialidade da representação pictórica moderna. Sua biografia foi pouco documentada e o que se sabe sobre o artista é que, apesar de ter sido discípulo de Leonardo da Vinci, não se firmou como um artista "cosmopolita" ao estilo de seu preceptor. O pintor espanhol produziu pouco em comparação aos pares de sua época e seu legado artístico manteve-se quase esquecido por muito tempo nos arredores de Valência.

Então, se a biografia de Fernando Yáñez não é tão exuberante como a de grande parte dos artistas renascentistas, torna-se preciso recorrer a sua principal obra para 
melhor compreender como um pintor do século XVI retrata a interação de culturas impressa na alma do homem moderno. A tela de maior destaque de Fernando Yáñez é sua Santa Catalina de Alejandría, datada de por volta de 1510 e adquirida em 1946 pelo Museo del Prado em Madri:

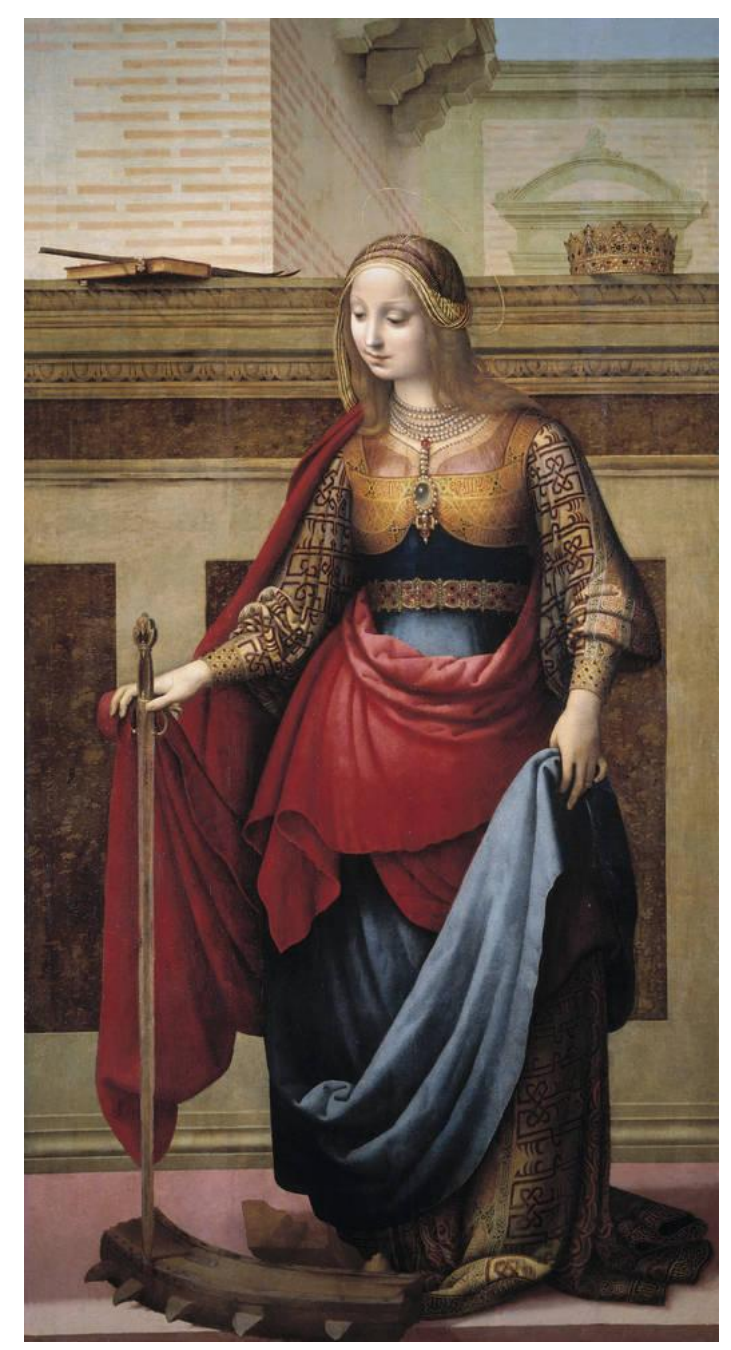

À primeira vista, não há como negar que a Santa Catalina de Alejandría é uma leitura humanista de um clássico tema religioso: a vida dos santos. Ao invés de valorizar o caráter místico da hagiografia de Santa Catarina, Fernando Yáñez alinhou-se com seu aprendizado na Florença do século XVI, preocupada em humanizar o que filosoficamente pertence ao mundo metafísico. Por isso, mais do que uma santa envolta na sobriedade que se espera de uma figura pura, a Santa Catarina de Yáñez é uma nobre dama do século XVI, luxuosamente vestida com sua jóia e com tecidos de cores vivas trazidos pelo próspero comércio oriental. A fidalguia da personagem central não é representada apenas pela coroa que ao fundo sugere relação com a realeza, mas, 
principalmente, pelo fausto do traje e do mármore do cenário, que se integra à candura de seus gestos. Aqueles que se preocupam em condicionar Yáñez a um padrão estético dirão que a feição de Santa Catarina é quase a de Monalisa, o que tornaria evidente a influência de Leonardo da Vinci e da pintura italiana quatrocentista. Mas o que de fato importa é o diálogo que a obra estabelece com o mundo do século XVI, e não necessariamente com um único circuito desse mundo plural.

Por isso, um historiador da arte diria que a doçura do rosto de Santa Catarina é um traço da influência italiana na obra; o cuidado com a vestimenta, uma característica flamenca, mas fatalmente poderia diminuir a importância de pequenos detalhes que conferem singularidade à obra, como, por exemplo, a geometria "arabesca" do vestido de Santa Catarina. Se essa característica não fosse tão central para o pintor, não estaria abertamente exposta nas mangas do vestido, nem tampouco revelada sutilmente por baixo da saia azul que, erguida pela mão esquerda, realça, pela graciosidade do gesto, a existência dessa geometria.

É evidente que o livro ao fundo representa a sabedoria da personagem, a palma o martírio cristão, consistindo a roda quebrada no próprio instrumento de tortura e a espada num indício de sua decapitação. Entretanto, se uma das questões centrais da arte renascentista é a subordinação do universo místico pela ação humana, o reconhecimento da cultura árabe como camada que "veste" a figura venerável merece mais destaque do que os símbolos óbvios da hagiografia de uma santa que, antes de ser cristã, pura e nobre, é principalmente "alexandrina". Desse modo, a Alexandria retratada por Fernando Yáñez não é a província romana do século IV vivida pela santa, mas a Alexandria árabe do século XVI que dialoga com a cultura mourisca ainda presente na Espanha formadora da consciência do pintor. A definição de Renascimento experimentada na obra Santa Catalina de Alejandría está além das acepções clássicas que criam uma Idade Moderna essencialmente voltada para a Europa, negligenciando o que Fernando Yáñez escancara em sua obra: a idéia de que o Renascimento é plural e se desenvolveu pela interação de culturas não somente cristãs e européias.

Alguém poderia alegar que o desenho árabe do vestido de Santa Catarina não é algo tão destacável na pintura de Fernando Yáñez. A composição pictórica do quadro estaria mais preocupada em relacionar-se com as influências italianas e flamencas da maneira de se conceber a arte do que voltada a exaltação da simbiose civilizacional do século XVI. Ainda que esse argumento crítico pareça plausível, ele não se mantém vivo ao se comparar a representação de Santa Catarina feita por Fernando Yáñez com outras 
obras do período que tiveram a vida dessa mesma santa como tema. Assim, torna-se preciso fazer uma análise direta de uma obra coetânea, como a Santa Catalina atribuída a Vecellio di Gregorio Tiziano (1473/1490 - 1576):

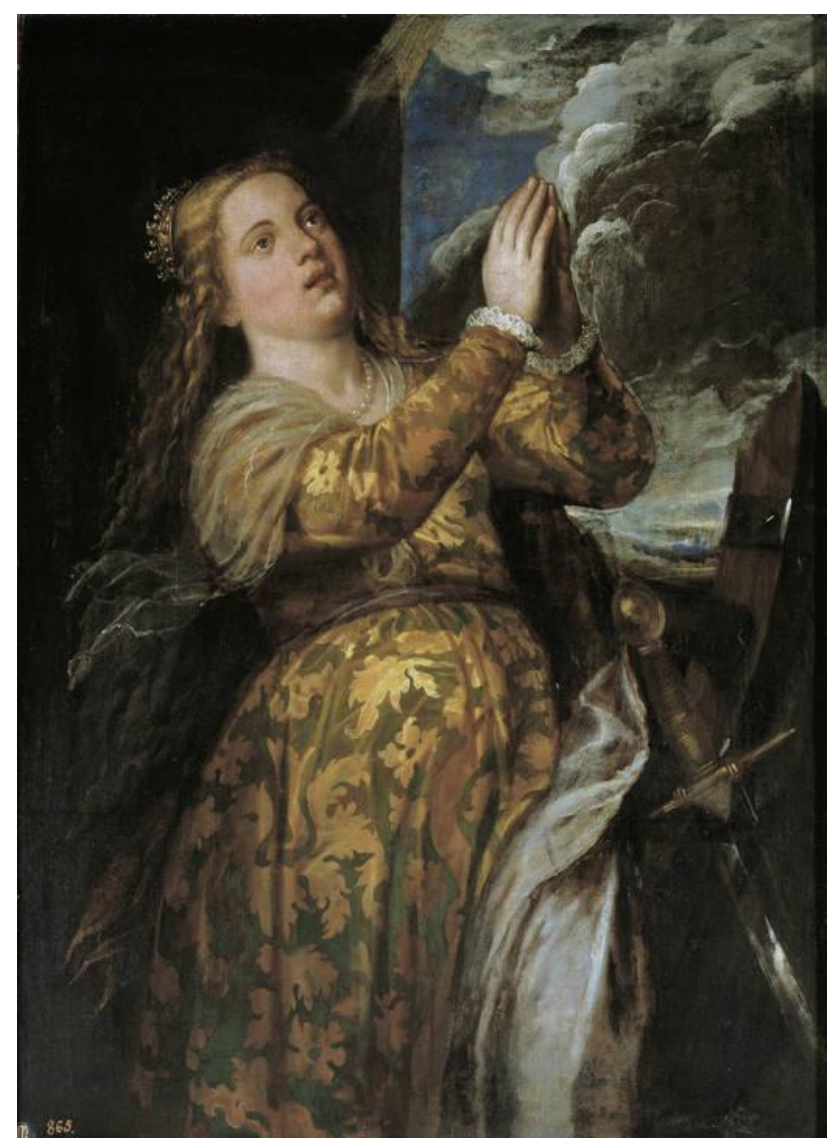

$\mathrm{Na}$ comparação entre as duas representações de Santa Catarina, vê-se que os principais símbolos hagiográficos são mantidos: espada, coroa e roda quebrada. Certamente, o que diferencia as duas obras é, juntamente com o fundo, a concepção da vestimenta da santa. A geometria arabesca de Yáñez não é referência para Tiziano, que opta por dissolver o esplendor do tecido oriental diante da dramaticidade do gesto, que nele é menos sutil, de sua Santa Catarina.

Ainda que diferentes, as obras de Fernando Yáñez e Tiziano são legítimas representantes da arte renascentista, com concepções distintas de Renascimento. O olhar de Tiziano para a sua época é mais fiel ao esplendor italiano, relacionando-se com a influência de Leonardo da Vinci a partir do uso intenso do chiaroscuro. Já em Yáñez, trata-se de uma visão do Renascimento mais simbiótica, combinando em sua Santa Catarina o sorriso sutil da Monalisa de Leonardo da Vinci com a referência simbólica à cultura árabe revelada como camada interna da personagem. 
De maneira menos intencional, o que fica manifesto na concepção de Renascimento de cada obra é que o homem moderno vive a quebra do monopólio explicativo sobre a experiência humana, possibilitando que o conceito central da obra de Fernando Yáñez seja a idéia de simbiose, enquanto o de Tiziano é o conflito. Na Santa Catarina do pintor espanhol nada é contrastante. A sutileza dos movimentos corporais da imagem central se alinha aos símbolos de nobreza e à quase inexistência de sombra na obra. Já em Tiziano, o confronto entre luz e sombra, brilho e opacidade é a expressão de uma subversão filosófica que humaniza o que é santo, e santifica o que é humano em Santa Catarina.

Certamente, a característica mais atraente do século XVI é a possibilidade de que coexistam nesse momento maneiras tão epistemologicamente distintas de conceber o presente. No século XVI, simbiose e conflito não significam conceitos antagônicos, mas, sim, são apenas partes de um modo dessacralizado de olhar para o antigo e para o moderno, identificando no mundo certa fluidez que permite ao homem negociar e combater as influências de culturas adventícias postas em contato pelo comércio, pela guerra, e, por que não?, pela arte.

Se, do ponto de vista artístico, as obras de Fernando Yáñez e Tiziano revelam concepções distintas de definição do conceito de Renascimento, na historiografia o olhar sobre esse período histórico também será controverso. Desde o século XIX, os historiadores se debruçam sobre o desafio de nomear e refletir sobre o legado histórico deixado pelo homem europeu dos séculos XV e XVI. Nessa perspectiva, o principal responsável por destacar a importância desse período como uma fase histórica ímpar foi Jules Michelet, que, ao compreender as contribuições culturais do Renascimento em oposição ao "obscurantismo" da Idade Média, alimentou uma polêmica historiográfica seguida por sucessivos autores como Jacob Burckhardt, Walter Pater, Johan Huizinga, Arnold Hauser e Erwin Panofsky ${ }^{30}$. Apesar de apresentarem argumentos diversos para redefinir o olhar do historiador para os séculos XV e XVI, esses autores possuem um ponto de convergência em seus argumentos: seja destacando nesse período histórico a importância da França, da Itália, de Flandres, da cultura pagã ou da cultura gótica, o Renascimento era uma experiência reconhecidamente europeia.

\footnotetext{
${ }^{30}$ Não se pretende aqui realizar um balanço historiográfico sobre o conceito de Renascimento. Existe uma vastíssima bibliografia que discute, de maneira pertinente, como a tradição historiográfica europeia relacionou-se com a compreensão do Renascimento como uma "fase histórica", definindo as transformações culturais, políticas e econômicas dos séculos XV e XVI como um fenômeno exclusivamente europeu.
} 
Somente nas décadas finais do século $\mathrm{XX}$ alguns historiadores deram início a um processo de relativização do "monopólio europeu" do Renascimento. Cabe citar aqui, como referência central desse novo olhar historiográfico, as discussões de Natalie Zemon Davis $^{31}$, mais preocupada com uma visão abrangente da experiência renascentista ao tratar de um homem moderno plural, que vivencia os séculos XV e XVI não somente nas artes, mas, sobretudo, no campo, no comércio e até mesmo na margem da sociedade de sua época.

Se o homem renascentista não é apenas um artista obcecado pela Antiguidade Clássica, ele também não pode ser definido por sua relação exclusiva com a cultura europeia. O Renascimento é uma experiência histórica que só foi possível porque as fronteiras do mundo moderno, principalmente no Mediterrâneo, estavam cada vez mais porosas. Ao mesmo tempo em que seus olhos se voltavam para o continente americano recém alcançado pelos navegantes, os homens renascentistas firmavam seus pés em um solo europeu movediço, impregnado de referências culturais provenientes da África e da Ásia. Em seu recente trabalho sobre a formação "global" do Renascimento, Jerry Brotton afirma que "um dos problemas com as definições clássicas do Renascimento é que elas celebram as conquistas da civilização europeia num movimento de exclusão de todas as outras" ${ }^{, 32}$. A proposta de Brotton é romper com a concepção monolítica de que a humanidade moderna foi construída na Europa renascentista centrada em si mesma, ressaltando as trocas culturais e comerciais entre o continente europeu e os povos orientais. Citando obras artísticas incontestáveis como a Comédia dos erros de Shakespeare, ou a tela Os embaixadores, de Holbein, Brotton destaca que o berço do Renascimento europeu foi o bazar do Mediterrâneo oriental, já que a cultura europeia construiu-se em relação à riqueza comercial e cultural avistada no contato direto com os orientais. A ideia de um Renascimento global não mitifica a presença do Oriente na Europa dos séculos XV e XVI, apenas relativiza as interpretações eurocêntricas de que o continente europeu está sozinho na elaboração da consciência do homem moderno.

A proposta de Brotton cria uma polêmica recente sustentada, sobretudo, pelo antropólogo britânico Jack Goody: Pode-se falar em um Renascimento de múltiplas influências no século XVI ou culturas de todo o mundo viveram diversos

\footnotetext{
${ }^{31}$ A importância de Natalie Zemon Davis é central no presente trabalho porque, para além de sua obra clássica Society and Culture in Early Modern France, a autora também escreveu uma das obras mais clássicas sobre a vida de João Leão Africano, Trickster Travels: a Sixteenth-century Muslim Between Worlds.

${ }^{32}$ Jerry Brotton. O Bazar do Renascimento: da rota da seda a Michelangelo. São Paulo: Grua, 2009, p. 38.
} 
"renascimentos" ao longo da história da humanidade? Para Goody o Renascimento não pode ser entendido como um único evento já que um olhar criador sobre o passado, que caracteriza em linhas gerais o Renascimento italiano, pode ser visto como um movimento transcultural ${ }^{33}$. Os exemplos do autor são numerosos, partindo da própria Europa com a referência a uma "renascença carolíngia" a partir do século VIII, a renovação do comércio veneziano com o Mediterrâneo oriental que resultou na quebra do monopólio dos religiosos sobre o conhecimento, e a chegada de bizantinos na Península Itálica com o Concílio de Florença (1438 - 1445). Da Europa, Goody se estende para a Ásia seguindo os exemplos transculturais como o chamado Renascimento timúrida na Índia islâmica do século XVI, e o retorno a uma antiguidade exemplar na China durante a dinastia Song no século XI.

Por trás da discussão sobre o conceito europeu de Renascimento está, para Goody, a necessidade da Europa em assegurar o monopólio sobre as conquistas da Antiguidade. Há um ímpeto europeu pela defesa da herança cultural greco-romana em nome de uma identidade europeia contemporânea que sequer era admitida pelos homens da Antiguidade. O mundo civilizado dos gregos e romanos concentrava-se no Mediterrâneo e se estendia em direção à Ásia Central, excluindo grande parte do norte da Europa que hoje sustenta com veemência o discurso de defensor dos louros do mundo antigo.

Apesar da crítica ao argumento de que a modernidade é exclusiva da Europa no século XVI, Goody não estabele uma controvérsia apenas com os estudiosos canônicos do Renascimento "europeu", mas parte de suas considerações reveem o próprio argumento de Brotton, que tenta dar maior visibilidade à contribuição oriental ao Renascimento italiano. O perigo desse discurso é a glorificação de um único "Renascimento" no século XVI, negligenciando que a florescência cultural por meio de uma valorização cultural do passado é um fenômeno observável em outros lugares e períodos da história.

O debate sobre o as origens do Renascimento não possui uma única resposta. A pergunta sobre o que foi a efervescência cultural do homem do século XVI talvez precise ser reformulada: Seria o Renascimento um conceito historicizável ou um

\footnotetext{
33 "Do ponto de vista histórico, o Renascimento italiano foi único. Sociologicamente, no entanto, devemos vê-lo não apenas como uma experiência europeia, mas como experiência de uma classe maior de eventos que ocorre em todas as culturas letradas e envolve tanto um olhar retrospectivo quanto um salto para a frente, nem sempre combinados num único evento."Jack Goody. Renascimentos: um ou muitos? São Paulo: Editora UNESP, 2011. p. 283.
} 
substantivo plural? O que se pode responder é que não há como pensar o século XVI na Europa, no Mediterrâneo e na África sem considerar duas lógicas distintas e complementares: o confronto e a negociação.

\subsection{Quando o sangue ferve: a Modernidade pelo confronto}

Ao se analisar o contato entre a Europa latina e o norte da África nos séculos XV e XVI, vê-se que o Islã atuou como uma espécie de mediador que oscilava entre a perspectiva do confronto e a aproximação de interesses específicos. O Estado português, que já no século XV chegava aos rincões da Ásia, fez da conquista de Ceuta, em 1415, o símbolo inaugural de sua expansão colonial marítima. A construção do império português moderno nascia com a vitória emblemática sobre possessões islâmicas africanas, o que corroborava um passado de enfrentamento com o Islã, surgido no chamado "milagre de Ouriques"34, de 1139. Seja pelo caráter religioso com que os enfrentamentos entre cristãos e muçulmanos se firmavam, ou pelo apoio aberto que a Igreja Católica dava à luta dos povos ibéricos contra a ameaça islâmica, sabe-se que a conquista de Ceuta não representou apenas a supremacia da Europa cristã sobre a África islâmica; tratou-se, isto sim, do estabelecimento do projeto de exploração comercial da costa africana por Portugal. A historiadora Jacqueline Hermann salienta que os tratados papais emitidos nos anos finais do século XV foram medidas reguladas pela Igreja Católica para garantir que as Américas ficassem sob domínio espanhol e a costa africana permanecesse como monopólio português. ${ }^{35}$ Assim como os tratados não foram respeitados, a história da presença portuguesa no Norte da África no século XVI também não pode ser vista como uma experiência totalmente bem-sucedida. Em 1515, por exemplo, já no reinado de D. Manuel I, Portugal viu seus planos de expansão

\footnotetext{
${ }^{34} \mathrm{O}$ "milagre de Ouriques foi uma batalha medieval ocorrida na região sul de Portugal entre cristãos e muçulmanos. O mito de Ouriques afirma que Jesus Cristo teria aparecido a D. Afonso Henriques antes do confronto como sinal do destino natural de supremacia do cristianismo frente o Islã. A batalha teria ocorrido no dia 25 de julho, data consagrada a Santiago, patrono da luta contra os mouros em toda a Península Ibérica. A primeira aparição de Santiago em uma batalha cristã contra os mouros teria ocorrido na Espanha em 844, na batalha de Clavijo.

35 "Partindo das Canárias em 1492 e chegando a terras que julgara serem grandes ilhas do mar da China, na verdade as Antilhas, a descoberta de Colombo acabou por levar o papa, sob influência espanhola, a lançar a bula Inter coetera, em 1493. Por essa bula foi definida uma linha imaginária cem léguas a oeste de Açores ou Cabo Verde, e tudo que ficasse além desse marco seria de Espanha, e aquém, de Portugal, o que rompia o estabelecido no Tratado de Alcáçovas, que punha termo à concorrência espanhola na costa africana e dividia o mundo a partir do paralelo das Canárias, ficando as terras ao norte para a Espanha e ao sul para Portugal". Jacqueline Hermann. No Reino do Desejado: a construção do sebastianismo em Portugal - séculos XVI e XVII. São Paulo: Cia das Letras, 1998, p. 26.
} 
territorial sobre a atual região do Marrocos sofrerem um revés com a destruição de sua armada pelos muçulmanos. O rei português, que já se intitulava "senhor da África", viu naufragar junto as suas naus o projeto de construção de duas fortalezas (Mamora e Anafé) nas cercanias da atual Casablanca marroquina.

O avanço do século XVI mostrou a Portugal que era mais vantajoso concentrar seus esforços nas rentáveis colônias da Ásia e do Brasil, retrocedendo na ambição imperial lusitana sobre as terras do Islã mais fronteiriças ao reino. ${ }^{36}$ Entretanto, a dilatação imperial portuguesa em direção ao Oriente criou no período manuelino um Estado inchado por uma burocracia pesada e custosa. Por isso, já na segunda metade do século XVI, as intenções de dirigir a expansão colonial lusitana para a África foram novamente consideradas quando, em 1578, “... com 24 anos e mais de 15 mil homens, dentre os quais 5 mil mercenários, D. Sebastião partiu para a África, recusando-se a ouvir os capitães experimentados em guerras africanas". 37 O resultado desse equívoco estratégico da coroa portuguesa foi o desaparecimento de D. Sebastião e a transformação de sua figura em um mito messiânico que seguiu vivendo no imaginário popular em distintas temporalidades por múltiplas regiões do antigo império português.

Se a imagem do confronto com a África islâmica sobreviveu na história de Portugal, em relação à Espanha ela não foi diferente. A experiência espanhola cristã do processo de Reconquista da Península Ibérica formou do século XI até finais do século XV um imaginário coletivo que alimentava o confronto contra o Islã. O historiador Roberto Marín Guzmán destaca como, por exemplo, a figura religiosa de Santiago de Compostela foi sendo forjada para representar o espírito bélico dessa época. A busca pela maior unidade entre os membros da Igreja Católica na região deu início a um movimento social, político e religioso que transformou o clássico São Tiago Maior,

\footnotetext{
36 "Ainda durante o reinado de d. Manuel, a tragédia de Mamora foi o primeiro grande desastre da primeira fase da expansão portuguesa no Norte da África. Nesse episódio, cerca de 4 mil homens, cem navios e toda a artilharia foram perdidos, além de a população destinada a colonizar ter sido vendida como escrava, depois de uma tentativa fracassada de construir duas fortalezas em Mamora e Anafé. (...) Em 1541, Portugal perdeu o domínio de sua posição mais meridional na região: Santa Cruz do Cabo da Gué, feito ruidosamente comemorado pelos mouros como a maior vitória alcançada contra os portugueses. No ano seguinte, ou em dezembro do mesmo ano, para alguns historiadores, D. Joao III mandou abandonar Safim, considerada base necessária para uma tentativa de ataque ao Marrocos, que chegou a ser sede de um bispado. Em 1549 e 1550, abandonou Alcácer Ceguer e Arzila". Idem, ibidem, p. 29.

${ }^{37}$ Idem, ibidem, p. 32.
} 
apóstolo da paz, em um santo guerreiro preparado para proteger os cristãos de seu inimigo comum: o Islã $\tilde{a}^{38}$.

Nesse projeto de expansão cristã no território muçulmano da Península Ibérica, a participação do Papado foi decisiva, principalmente na afirmação da imagem de Santiago como protetor dos que guerreavam contra os muçulmanos. Ao papa Calixto III foi atribuída uma obra que especificamente incentivava a devoção e a peregrinação a Santiago de Compostela, o Liber Sancti Jacobi, Codex Calixtius. Essas ações de popularização da figura de Santiago na Espanha podem ser entendidas como parte de uma estratégia de união e autodefesa cristã em uma região de fronteira com territórios islâmicos. O confronto militar e a dominação política da Espanha Islâmica necessitava, aos olhos de Roma, da integração total dos cristãos da região em uma única frente militar de combate. O papel da Igreja Católica seria o de preparar a integração dos cristãos da Espanha entre si e com o resto da Cristandade européia, para que o fortalecimento da comunidade cristã europeia favorecesse a ampliação dos exércitos dos reis católicos espanhóis.

No interior desse projeto de unificação cristã, os mosteiros e as ordens religiosas tiveram uma atuação fundamental desde o século XI. A ação das Ordens de Cluny e de Cister na Espanha teve como propósito levar à região a influência cultural e artística que se estabelecera no resto do continente europeu cristão, permitindo maior integração entre os espanhóis e toda a Cristandade que se submetia mais fortemente a Roma. As reformas trazidas por essas ordens ao cotidiano e ao imaginário da população local serviam claramente aos interesses expansionistas dos reis cristãos da Península Ibérica, que, cada vez mais, designavam privilégios aos monges em troca de favorecimento a seus objetivos políticos. ${ }^{39}$ Assim, é notório que os monastérios espanhóis atuaram diretamente no processo de Reconquista, sendo simultaneamente instrumento religioso dos reis cristãos e político da Igreja Católica. Uma das maneiras dessas ordens atuarem

\footnotetext{
38 "El camino de Santiago de Compostela y la peregrinación que se practicó hacia la tumba del Apóstol, fueron importantes elementos para la formación de la Reconquista como ideología, sobre todo porque desarrolló un sentido de unidad de la Iglesia y de los cristianos contra el Islam, el enemigo común. La transformación en el carácter del santo, de un Apóstol de paz a un guerrero que daba muerte a los enemigos y que estaba listo para luchar al lado de los cristianos contra los musulmanes, muestra también los cambios ideológicos de la Iglesia a favor de una misión universal, que se involucraba directamente en el proceso de Reconquista de España”. Roberto Marín Guzmán. Sociedad, política y protesta popular en la España Musulmana. San José: Editorial UCR, 2006, p. 489.

39 "Es oportuno llamar la atención sobre el importante papel socio-económico que jugaron los monasterios en España en la colonización de las diversas regiones ganadas a los musulmanes. Tanto los monasterios de Cluny como los de la Orden del Císter, se convirtieron en plazas fuertes en el proceso de Reconquista y colonización de las tierras reconquistadas a los musulmanes". Idem, ibidem, p. 494.
} 
de modo favorável aos interesses do Papado e dos reis locais foi através da luta aberta contra os muçulmanos de al-Andaluz. A circulação desses monges pelo território espanhol permitiu a rápida divulgação dos resultados do Primeiro Concílio de Latrão, que em 1123 já afirmava que a Reconquista da Espanha equivaleria à Cruzada direcionada à Terra Santa.

Quanto maior era o avanço islâmico em direção aos territórios cristãos do Oriente Médio, mais forte se alimentava o espírito de Reconquista na Espanha, o que mostrava que o trabalho dos monges na região estava sendo muito bem executado. Quando em 1187 Jerusalém foi recapturada por Saladino (صلاح الدين يوسف الأيوبي), o projeto de expulsão dos muçulmanos da Península Ibérica se transformou em objetivo prioritário, não somente por questões religiosas, mas, sobretudo, por duas razões menos nobres ainda: a necessidade de expandir a atividade econômica na região e de resolver o problema crescente do aumento populacional nos reinos cristãos do Norte da Espanha. ${ }^{40}$

Mas o avanço experimentado pelos cristãos nesse momento não se manteve com a mesma presteza. A ascensão de duas dinastias islâmicas e berberes na região (Almorávida e Almoada) deteve o processo de Reconquista até a formação de um exército conjunto dos reinos cristãos em princípios do século XIII. Castelhanos, aragoneses, navarros, leoneses, portugueses e franceses uniram-se no objetivo comum de aniquilar a dinastia Almôada na Batalha de Las Navas de Tolosa em 1212.

Dentre os casos de confronto entre as "Espanhas" islâmica e cristã, aquele que melhor repercute no Norte da África é a disputa pelo último reduto muçulmano da Península Ibérica, o Reino de Granada de finais do século XV. É nesse momento que ocorrem os maiores enfrentamentos entre os muçulmanos de Granada e os cristãos dos reinos circunvizinhos, principalmente após o casamento de Fernando II de Aragão ${ }^{41}$ com Isabel I de Castela. Com o matrimônio de Fernando e Isabel (chamados de "Reis Católicos"), a histórica rivalidade de aragoneses e castelhanos foi diluída, o que dificultava qualquer resistência do Reino de Granada ao ataque das tropas cristãs, pois tal resistência sempre se baseara na exploração da rivalidade entre os nobres cristãos da região.

\footnotetext{
40 "Aparte de las razones religiosas e ideológicas y la ayuda internacional, otro factor que también contribuyó al éxito del proceso de la Reconquista fue el más rápido crecimiento de la población en los reinos cristianos del norte de la Península que en al-Andalus, en especial a partir del siglo XI. (...) La Reconquista no fue solo un acontecimiento político y militar, sino también un asunto económico y social: la expansión cristiana hacia el sur de la Península asimismo demandó el arduo trabajo de colonizar las regiones reconquistadas". Idem, ibidem, pp. 496-497.

${ }^{41}$ Fernando II de Aragão, o Católico, também chamado Fernando V de Aragão e Castela após o casamento com Isabel I de Castela.
} 
Entre 1482 e 1492, o espírito cruzadístico que sustentou por séculos a Reconquista da Península Ibérica ganhou um impulso econômico que foi rapidamente transformado em armas e tropas voltadas para a captura de Granada ${ }^{42}$. Assim, entre janeiro e março de 1492, Granada se entregou aos cristãos, negociando condições para a sua rendição imediata, tais como a garantia de que os muçulmanos poderiam seguir professando sua fé, que suas propriedades seriam preservadas, bem como a língua árabe e os costumes locais. Evidentemente, muitas das promessas firmadas durante a rendição granadina não foram cumpridas.

Como medida complementar à tomada de Granada e ao desmoronamento da influência islâmica na Península Ibérica, os cristãos estimularam a emigração dos muçulmanos para o Norte da África, especialmente para a região do Marrocos. O arabista espanhol Serafín Fanjul afirma que “... ya en 1493 salieron unos seis mil moros en compañía de Boabdil, sobre todo gente de la aristocracia nazarî. ${ }^{43} \mathrm{O}$ fluxo crescente de exilados em direção ao Marrocos afetou diretamente a estabilidade social da Península Ibérica. O apoio que essa população emigrada dava às rebeliões dos mouros que permaneciam em terras espanholas fez com que o equilíbrio interno do reino espanhol dependesse da continuação do projeto castelhano de expandir seus domínios à costa africana. A discussão sobre o avanço na África expunha a existência de dois projetos imperiais distintos no interior da política espanhola: a idéia de que a Espanha deveria concentrar sua força militar na manutenção de seu poder reconquistado na Península Ibérica (engendrada pelo rei Fernando), e o intento de se criar um império espanhol na África que se aproximasse das fronteiras do deserto do Saara (encabeçado pelo cardeal Francisco Jimenez de Cisneros). A vitória do projeto do rei Fernando criou alguns problemas para a supremacia dos reinos cristãos ocidentais no mar Mediterrâneo. O estancamento da expansão espanhola na África permitiu o fortalecimento da presença muçulmana na região. Ainda que a Espanha tivesse conquistado pequenos enclaves na

\footnotetext{
42 "Así, por ejemplo, en los últimos diez años de estas acciones militares contra el Reino Nasrí de Granada, los Reyes Católicos lograron la predicación de la Cruzada en cinco ocasiones entre 1482 y 1492. De esta forma, con el propósito de obtener indulgencias, la gente contribuyó dadivosamente con fondos para la Cruzada. Se ha calculado que se recaudaron 650.000.000 de maravedíes en Castilla, Aragón y Navarra. Castilla fue la que más proporcionó, cerca del $85 \%$ de esa cantidad. Junto a la predicación de la Cruzada y la recaudación de los subsidios de la Cruzada, los eclesiásticos también aportaron de sus propias rentas institucionales, lo que se ha calculado que alcanzó la suma de otros 160.000.000 de maravedíes". Idem, ibídem, p. 528.

${ }^{43}$ Serafín Fanjul. Descripción General del África y de las Cosas Peregrinas que allí hay. Granada: Fundación El Legado Andalusí. 2004, p. 20.
} 
costa africana, como Orã, Mazalquivir e Melilla, a maior parte dos territórios do Magreb firmou-se como possessões islâmicas.

Ao longo do século XVI, a Espanha pagaria um alto preço por ter escolhido diminuir sua dilatação no Mediterrâneo. O sucessor de Fernando na coroa espanhola, Carlos V, seguiu confrontando-se com os povos muçulmanos que ameaçavam sua tentativa de união de toda a Cristandade sob sua coroa e de controle absoluto da navegação no mar Mediterrâneo. Entre alianças com o Império Persa e confrontos com o Império turco-otomano na Europa Oriental e no Mediterrâneo, o século XVI não permitiu que os reinos da Península Ibérica vivessem sem o desafio de conviver com os avanços do poder islâmico sobre regiões fronteiriças, como a África e sua costa.

Enquanto Portugal e Espanha mantinham certa dualidade nas relações com os territórios islâmicos, a Península Itálica também sofria certa instabilidade interna provocada pela relação cada vez mais inevitável com os interesses dos impérios islâmicos no Mediterrâneo. A “Itália" do século XVI é uma região ainda retalhada em pequenas repúblicas, condados e ducados rivais como Florença, Gênova, Veneza, Milão, Nápoles, Sabóia, entre outros. Além dessas importantes cidades, a região também contava com os chamados "Estados Pontifícios", um conjunto de territórios no centro da península que tinham Roma como capital e o Papa como soberano.

Quando se tomam os Estados Pontifícios como referência do conflito entre Islã, Cristandade e Humanismo na Idade Moderna, vê-se que não há como separar a atuação do Papa frente ao Islã das questões políticas que o papado sofria no interior de sua própria concepção universalista de "Igreja". O litígio entre papado e igreja que caracteriza o Renascimento europeu coloca sob tensão a ideia de universalismo eclesiástico próprio da Cristandade medieval. Essa crise doutrinal afetou não somente o comportamento do papado frente aos impérios europeus na modernidade, como também a relação dos Estados Pontifícios com o crescente poder político do Islã em todo o Mediterrâneo. ${ }^{44}$ Ao longo dos séculos XV e XVI, a Igreja Católica seguiu perdendo sua concepção universalista de ecclesia, principalmente a partir das repercussões críticas a

\footnotetext{
44 "Nesse sentido, a tensão universalista da Idade Média no plano político contrasta, no Renascimento, com uma Realpolitik que, mesmo justificada pelas condições históricas de toda a Europa, sem dúvida alguma possui uma motivação intrínseca à vida da igreja, ou melhor, ao seu paradigma teológico hierárquico. O evento novo, na concepção eclesiológica do Renascimento, é representado pelo divórcio entre papado e igreja". Giuseppe Roccaro. Humanismo e Islã: Consummatio Modernitatis e Contemporaneidade. Nos rastros de um ato ideológico. (IN): Arno Dal Ri Junior e Ari Pedro Oro (orgs.). Islamismo e Humanismo Latino: Diálogos e desafios. Petrópolis: Editora Vozes, 2004, p. 52.
} 
Roma surgidas a partir do Cisma de 1378, em que a Igreja Católica contou, em um curto período, com três sedes pontifícias: Roma, Avignon e Pisa.

Esse cenário de desagregação da unidade mandatária refletiu diretamente no pensamento filosófico e teológico da chamada "Escolástica Tardia", mais especificamente no momento de florescimento e consolidação do Humanismo latino. De acordo com Giuseppe Roccaro, "a eclesiologia foi o tema de fundo da teologia da tarda escolástica, ou seja, no momento de passagem ao Humanismo. Efetivamente, se os temas mais quentes do debate teológico são os da plenitudo potestatis e das relações entre poder temporal e espiritual, certamente permanece como questão fundamental a de natura ecclesia". ${ }^{45}$

Se até mesmo no campo doutrinal via-se a perda da força unitária da Igreja Católica, no campo político era inevitável que o poder papal sofresse uma paulatina fragmentação ao raiar da modernidade. Ainda que o Concílio de Constança em 1414 e o Concílio de Basiléia-Ferrara-Florença entre 1431 e 1445, tenham tentado resgatar o poder do Papa sob a universalidade da Igreja, as consequências políticas dessa perda de autoridade já se mostravam irrefreáveis não somente pela afirmação dos poderes temporais na Europa Ocidental, como também pela quebra do universalismo religioso do Cristianismo com a chegada da chamada "questão turca" no Ocidente. A ameaça representada pelos enfrentamentos cada vez mais constantes dos reinos europeus com o Império Otomano mostrava que, à revelia do Cristianismo, existia outra realidade universal que ameaçava a unidade da Europa: o Islã. Enquanto os reinos cristãos europeus comemoravam as sucessivas vitórias de Portugal e Espanha frente aos povos islâmicos da Península Ibérica, a Cristandade lamentava a perda de Constantinopla para os turcos em 1453. O resultado desses tempos sombrios para o Papado foi o já citado renascer de um espírito cruzadístico na Europa, que cada vez mais, não somente combatia, mas também concorria e negociava com as lideranças islâmicas da época.

Entretanto, no interior da Igreja Católica havia pequenos focos de resistência ao ambiente de Cruzada que se instaurava. Alguns pensadores do século XV, como Juan de Segóvia e Nicolau de Cusa, defendiam a possibilidade de uma aproximação teológica com o Islã, substituindo a belicosidade por uma possibilidade de negociação com o inimigo através da reflexão inter-religiosa. A base do pensamento desses religiosos era a dúvida sobre a possibilidade de conversão direta dos muçulmanos ao Cristianismo, o

\footnotetext{
${ }^{45}$ Idem, Ibidem, p. 53.
} 
que reforçava a necessidade de se estabelecerem pontos em comum entre a doutrina católica e a islâmica. Com esse intuito, Juan de Segóvia produziu uma tradução do Alcorão partindo do castelhano para o latim, já traduzido do árabe ao castelhano. Essa edição é conhecida como Alchoranus trilinguis. Além dessa versão corânica, Juan de Segóvia também escreveu a obra De mittendo gladio Divini Spiritus in cordia sarracenorum, em que propõe a conversão dos muçulmanos pela via da paz. ${ }^{46}$ Já Nicolau de Cusa buscou a reflexão sobre formas de dialogar com o Islã em duas obras: De pace fidei e Cribatio Alchorani.

Em todas essas obras, e com maior intensidade em De pace fidei, vê-se que as impressões desses autores sobre o Islã são mediadas por textos latinos anteriores que se debruçaram sobre os princípios “maometanos”. Juan de Segóvia e Nicolau de Cusa não inauguraram a curiosidade da Igreja Católica pelo Islã, mas propuseram um apaziguamento engajado das relações entre essas duas concepções religiosas universalistas que se enfrentavam política e militarmente. Assim, a postura crítica a uma trajetória medieval de confronto inevitável com o Islã é substituída por uma transferência do confronto para o campo do intelecto, atitude própria de uma mudança de posicionamento sobre o mundo que caracteriza o homem humanista latino. A posição de Juan de Segóvia e Nicolau de Cusa não anula a possibilidade de conflito entre Islã e Cristandade, mas propõe um modelo alternativo de se relacionar com o universalismo concorrente da civilização islâmica. Para ambos os autores, não se discute a segura superioridade da mensagem cristã sobre a islâmica; o que se aventa é se essa superioridade deve mostrar-se pelas armas ou pela palavra reflexiva.

É nesse ambiente de curiosidade sobre o Islã e de ponderação sobre como enfrentar o inimigo crescente que a cultura islâmica moderna entra em contato com o humanismo latino, a resistência do universalismo católico e com o ambiente intelectual favorecido pelo mecenato vigente no Ocidente cristão. Não só de conflito viveu o contato entre Islã e Cristandade, seja na Europa, na Ásia ou, sobretudo, no Norte da África a ser desvendado.

\footnotetext{
46 "El núcleo esencial del método está, pues, bien claro, pero con no menor claridad se subraya que la finalidad no es otra que la conversión de los musulmanes, intención que se pone de manifiesto en el prólogo mencionado, así como en la carta de Nicolás de Cusa y en la obra De mittendo gladio Divini Spiritus in corda sarracenorum, cuyo sumario comienza afirmando que por la exposición de la palabra divina se ha de tender a la conversión de los sarracenos. En resumen y empleando sus propias palabras, el principio, el medio y el fin de esa obra no es otro que emprender la vía de la paz más que la de la guerra para lograr la conversión de los sarracenos". Víctor Sanz Santacruz. Juan de Segovia y Nicolás de Cusa frente al Islam: su comprensión intelectualista de la fe cristiana. Anuario de Historia de la Iglesia (2007), p. 187.
} 


\subsection{Onde há fumaça, nem sempre há fogo: a Modernidade pela negociação}

As relações entre reinos cristãos ocidentais e povos muçulmanos floresceram ao nascer do século XV e ao longo de todo o século XVI, mas não somente em territórios próximos como a África. A expansão dos impérios marítimos europeus em direção à Ásia fez do Oriente Médio outro espaço fronteiriço de confronto e negociação com regiões administradas por líderes muçulmanos.

Antes mesmo do fortalecimento da presença colonial européia no continente asiático, os Reinos de Espanha e Portugal já mostravam interesse sobre o que acontecia na região do Oriente Médio, principalmente no que se referia ao destino do último império cristão oriental, sediado em Bizâncio. Em 1453, a invasão turco-otomana de Constantinopla, capital do Império Bizantino, aguçou as intenções dos ibéricos em se expandirem em direção ao Oriente que mais os cercava. Alguns historiadores como José Francisco Cutillas Ferrer chegam a citar a presença de viajantes espanhóis na Pérsia desde 1404, o que resultou numa embrionária troca de embaixadores entre os dois impérios $^{47}$.

Mas, para destacar o momento em que as relações entre os impérios ibéricos e, mais especificamente, a Pérsia passaram a render frutos políticos e comerciais, não há como escapar da ressonância que a queda de Constantinopla teve nas cortes ocidentais. A destruição do último bastião de resistência do cristianismo no Oriente Médio fez com que a Europa vivesse a necessidade de coexistir com uma nova potência imperial que apresentava ambições comerciais no Mediterrâneo, os otomanos. A Espanha cristã, que já vivia o supracitado enfrentamento com líderes islâmicos na Península Ibérica, passou a ter de se preocupar com uma possível nova frente de combate contra os seguidores turcos do Profeta Muhammad. Desse modo, a ameaça otomana uniu em condição de potenciais aliados os distantes imperadores das nações ibéricas e da Pérsia. Se aos espanhóis parecia óbvio o rechaço à ameaça comercial dos turcos otomanos, os persas possuíam seus próprios motivos para considerá-los inimigos mortais. As relações do Xá

\footnotetext{
${ }^{47}$ De acordo com José Francisco Cutillas Ferrer, Enrique III de Castela e Leão teria enviado uma expedição amistosa à Pérsia integrada principalmente por Pelayo de Sotomayor, Fernando de Palazuelos e o escritor Ruy Gonzáles de Clavijo, relator da viagem. José Francisco Cutillas Ferrer. El siglo XVI y El comienzo de las relaciones diplomáticas con Persia: Carlos V y Sha Ismail. (IN): Maria Jesus Rubiera Mata. Carlos V, los moriscos y El Islam. Madrid: Editora Museo del Prado, 2000, s/p.
} 
Ismail com o Sultão otomano Selim ficavam cada vez mais tensas pela disputa de poder religioso e territorial entre esses dois impérios no Oriente Médio.

Ainda que a Espanha fosse o primeiro império ocidental a estabelecer relações diplomáticas com a Pérsia, não há dúvida de que foi o expansionismo marítimo do Império português que inaugurou o contato permanente entre Oriente e Ocidente na Era Moderna. Ao cruzar pela primeira vez o Mar Vermelho partindo do Egito em direção às Índias, Portugal preocupou-se em constituir uma feitoria na ilha de Ormuz, em pleno território persa. Em 1507 houve o primeiro contato direto entre portugueses enviados por Dom Manuel I e o Xá Ismail. Já em 1513, após uma derrota significativa das tropas persas diante do exército otomano, o Xá firmou um acordo com Afonso de Albuquerque $^{48}$, que outorgava aos portugueses a posse de Ormuz, o que fazia com que o rei de Ormuz renunciasse a sua lealdade direta à Pérsia e passasse à condição de vassalo português. Dessas negociações diplomáticas nascia um dos primeiros acordos de cooperação militar entre a Pérsia e o Ocidente. O sucesso dos pactos militares com Portugal fez com que o Xá Ismail almejasse estender esse benefício a outros reinos europeus. Motivada pelo rechaço à ameaça turco-otomana, a Pérsia buscou manter relações amistosas com a Espanha de Carlos V e a Hungria de Luís II, tentando constituir uma frente europeia de contenção às ambições expansionistas do Sultão otomano.

Enquanto a Pérsia organizava uma rede de alianças contra os turcos, o Império otomano também procurava possíveis aliados no Ocidente europeu. Há inúmeros estudos sobre as relações diplomáticas entre a França de Francisco I e o império otomano de Solimão, o Magnífico ${ }^{49}$, ambos desejosos de sobrepujar a ampliação territorial de Carlos V. Uma das fontes mais ricas usadas pelos historiadores para compreender a dinâmica dessas alianças entre impérios islâmicos e cristãos é a correspondência trocada entre esses governantes. Em seus estudos sobre a rivalidade entre Carlos V e Solimão II, a historiadora turca Ozlem Kumrular ${ }^{50}$ recorreu aos

\footnotetext{
${ }^{48}$ Afonso de Albuquerque: militar de origem nobre foi nomeado governador da Índia portuguesa. Fez sua carreira militar no Norte da África e, depois, transferiu-se para o Oriente. Antes de morrer, ganhou de D. Manuel I os títulos de vice-rei e Duque de Goa. A importância das ações militares e políticas de Afonso de Albuquerque foi reconhecida rapidamente por Portugal, que conferiu a um nobre não pertencente à família real, pela primeira vez, o título de Duque.

${ }^{49}$ Respeitando a nomenclatura historiográfica turca, passo a chamar Solimão, o Magnífico de "Solimão II".

${ }^{50}$ Destaco, aqui, duas obras: Ozlem Kumrular, Las relaciones entre El Imperio otomano y la monarquía católica entre los años 1520-1535 y el papel de los Estados satélites. Istambul: Editorial Isis. 2003; e também: Ozlem Kumrular. El duelo entre Carlos V y Soliman El Magnífico (1520-1535).
} 
arquivos epistolares para discutir o conflito expansionista que transformou a Europa e a Ásia em pleno século XVI. Kumrular garante que as hostilidades entre os grandes impérios da época não se davam somente no campo militar, já que, para além dos enfrentamentos bélicos, os antagonistas apelavam às armas retóricas da ridicularização e da provocação. Em carta a Fernando, irmão de Carlos V, por exemplo, Solimão II teria dito: "Há muito tempo se duvida de tua virilidade. Falta-te palavra de compromisso! E a teu irmão também! Se és varão, vem ao meu encontro".

Mesmo que geograficamente o império persa do século XVI estivesse distante dos reinos europeus, no campo estratégico-militar encontrava-se entre dois gigantes imperiais: o Sacro Império de Carlos V e a "Sublime Porta" de Solimão II. A Pérsia safávida, aliada de Carlos V, não ficou imune às ações otomanas. Em disputa, estavam colocadas à prova mais do que a honra dos imperadores orientais. O que se pleiteava também era o mando de um único líder em terras islâmicas e o controle econômico e militar do Oriente Médio. À revelia das consideráveis derrotas infligidas ao Xá Ismail e a seu sucessor Tahmasp I, o Império Otomano não concretizou seu velho projeto de controle exclusivo dos principais centros islâmicos, o que colocava a Pérsia em confluência de interesses com os impérios ibéricos na Ásia. As permanentes batalhas entre persas e turcos otomanos ao longo do século XVI favoreceram a permanência de Portugal em Ormuz, pois tornavam ainda mais distante a possibilidade de uma intervenção armada dos turcos nas possessões portuguesas da região.

Para a Pérsia, a presença dos portugueses em Ormuz também era uma garantia de que os turcos tivessem pudores em empreender uma ação militar incisiva em seus territórios. O domínio português sobre Ormuz não se caracterizava como uma colônia prioritária, mas apenas como um entreposto comercial, o que garantiria a necessidade de Portugal manter relações cordiais com a Pérsia para a defesa de sua feitoria. Na primeira metade do século XVI, Portugal, como demonstração de sua cordialidade para com a Pérsia, manteve nominalmente a soberania das lideranças locais persas em Ormuz, concedendo-lhes direitos de sucessão de poder. Com o tempo, apoiando-se na aliança com a dinastia safávida, os portugueses se beneficiaram das rendas econômicas extraídas de sua feitoria persa, que se transformava em ponto de intermediação entre o comércio com outras regiões da Ásia, como a Armênia, a Arábia e as terras tártaras. Foi dessa maneira que Portugal assegurou o fluxo crescente de caviar do Mar Cáspio, de pérolas do Bahrein, de cavalos da Península Arábica e de especiarias da Índia. 
Mesmo com tantas riquezas, manter uma linha de defesa em Ormuz mostrava-se uma tarefa penosa e dispendiosa para Portugal. A situação geográfica, os altos valores perdidos pelos portugueses com a corrupção e a constituição geológica da ilha impediam um plano exclusivo de Lisboa para a conservação de tão importante fonte de divisas. O historiador Luis Gil Fernández assegura que, diferentemente de outras regiões comerciais do Oriente Médio, como a costa da Arábia, habitada por "mouros árabes" e judeus, e guarnecida de fortes eficientes que resguardavam seus portos, Ormuz não contava com todos esses recursos de proteção. Apesar das diversas ampliações sofridas pelo forte português da ilha, sua defesa não podia ser garantida sem o estabelecimento de relações cordiais com a população local acostumada à autoridade (ainda que nominal) das lideranças persas. Outro problema comum em Ormuz era a falta de água potável. Para garantir o abastecimento da ilha era necessário recorrer às reservas de água da Pérsia continental, reforçando os vínculos de Portugal com os poderes locais. ${ }^{51}$

Se do ponto de vista político, material e militar as bases para a influência estrangeira estavam firmadas na Pérsia, o mesmo ocorreu com os fundamentos religiosos islâmicos incorporados durante a dinastia safávida. Desde a ascensão do já citado Xá Ismail, a Pérsia foi forçosamente convertida ao xiismo duodécimo. A autora Nikki R. Keddie afirma que a fé instituída pelos primeiros governantes safávidas era de origem exterior à Pérsia, sendo uma apropriação feita pelos membros desse clã quando tiveram contato com tribos nômades da região da Anatólia. ${ }^{52}$ Independentemente da origem do contato da Pérsia com o xiismo duodécimo, o que merece destaque é a condição adventícia dessa matriz religiosa.

A opção do Xá Ismail pela transformação do xiismo duodécimo em religião oficial do seu império pode ser explicada pela capacidade de adequação que a doutrina duodécima apresentava em relação aos interesses safávidas. Para uma dinastia que acabava de chegar ao poder, contar com o apoio de fundamentos religiosos é uma maneira eficaz de construir legitimidade política. A grande estratégia de dominação erguida pelos primeiros imperadores safávidas para garantir sua supremacia sobre o trono persa foi combinar às alianças militares com a Europa, a absorção da antiga burocracia persa e a importação de religiosos xiitas duodécimos de terras vizinhas como

\footnotetext{
${ }^{51}$ Luis Gil Fernández. El Imperio luso-español y la Persia safávida. Tomo I (1582-1605). Madrid: Fundación Universitaria Española, 2006.

52 Nikki R. Keddie. Las raíces del Iran Moderno. Barcelona: Belacqua, 2006.
} 
os atuais Bahrein e Síria. Como tradicionalmente os habitantes da Pérsia não eram praticantes do xiismo duodécimo, era preciso institucionalizar a fé do Xá, e para isso o império necessitou de mão de obra religiosa estrangeira. De forma mais contundente do que outras dinastias islâmicas, os safávidas buscaram a difusão de sua matriz islâmica oficial, moldando os preceitos religiosos aos seus próprios interesses. Essa adaptação do xiismo duodécimo ao projeto de poder dos safávidas era perceptível em dois aspectos: a defesa das diferenças entre Islã xiita e Islã sunita; e a crença na sacralidade dos Imames (A'imma: الأئمة, no singular, Imam: الإمام (1)

O Xá Ismail, por exemplo, exigia que os religiosos xiitas trazidos de terras vizinhas divulgassem a idéia de que os muçulmanos sunitas eram hereges. Essa estratégia de ataque doutrinário aos sunitas era conseqüência da necessidade de conversão rápida dos súditos persas ao xiismo duodécimo, e, principalmente, da urgência em transformar o Império turco otomano (predominantemente sunita) em rival legítimo no jogo político internacional dessa época. Em pleno século XVI, fazia mais sentido a um súdito persa lutar contra um herege do que contra um irmão de fé, impondo-se, desta maneira, a necessidade de se fazer com que os otomanos fossem mais reconhecidos como um império sunita do que como um governo vizinho de predicação islâmica. No interior dessa lógica de combate à ameaça militar e religiosa da Pérsia, os safávidas conseguiram justificar suas alianças com os cristãos europeus contra um império islâmico concorrente. Além do reforço ao sectarismo xiismo/sunismo, os safávidas souberam adaptar de modo eficaz algumas concepções duodécimas à legitimidade política de sua dinastia. Os primeiros governantes safávidas, Ismail e Tahmasp I diziam-se descendentes do sétimo Imam, o que lhes conferia uma respeitabilidade simbólica baseada na idéia de encarnação sagrada presente em algumas leituras xiitas. Assim, a observância desses preceitos pela atuação dos religiosos xiitas a serviço do Xá permitia ao Império Persa uma originalidade ideológica e uma identidade própria que o tornava capaz de concorrer com seus principais inimigos militares sunitas, o Império otomano e os Uzbeques da Ásia Central.

A postura anti-otomana da dinastia safávida fez com que o Império Persa também extraísse benefícios econômicos de sua relação com os Estados europeus aliados. Na segunda metade do século XVI, principalmente durante o governo do Xá

\footnotetext{
53 الإماد (Imam): guia ou chefe. A autoridade e o poder atribuídos ao Imam, chefe da comunidade muçulmana. Sua condição de sacralidade varia de acordo com a interpretação do grupo religioso islâmico que se utiliza desse conceito.
} 
Abbas I, a atividade comercial da Pérsia foi incrementada com a construção de estradas e grandes oficinas. Esses investimentos estruturais do Xá visavam a satisfação da demanda européia por produtos orientais, principalmente por tecidos, especiarias e produtos manufaturados como a cerâmica. Ainda que a Europa já começasse a constituir suas primeiras colônias na Ásia (como no caso de Ormuz), o fluxo de mercadorias orientais para lá necessitava da participação persa, até que paulatinamente, as rotas comerciais marítimas dominadas pelos impérios europeus fossem autossuficientes. Mesmo com o desenvolvimento gradual da presença marítima europeia nos mares orientais, a Pérsia assegurava às embarcações portuguesas e espanholas (principalmente) um entreposto para tornar a viagem até a Índia mais segura. A proximidade com os safávidas permitia aos navegadores contar com uma base estratégica ao longo do percurso, garantindo maior assistência à frota. A fortaleza de Ormuz e a Pérsia converteram-se em peças estratégicas do interesse econômico europeu pelo Oriente. Portugal, por exemplo, sabia que controlar essa colônia era a maneira mais rápida e eficaz de interferir na circulação de mercadorias orientais para a Europa, seja pelas rotas terrestres, seja, principalmente, por via marítima.

Não tardou para que Ormuz se transformasse em objeto de desejo dos impérios europeus que concorriam com Portugal pelo monopólio do comércio de especiarias. A historiadora Marta da Graça Borges chega a mencionar que, em fins do século XVI, Ormuz se convertera em um "estreito globalizado", já que, após o êxito da aliança com portugueses e espanhóis, os Xás safávidas estabeleceram laços diplomáticos com a Inglaterra e a Holanda. ${ }^{54}$ As disputas por Ormuz e pelas rotas marítimas às Índias fizeram com que o Império Persa se incorporasse ao jogo europeu das relações internacionais na Idade Moderna. Ao longo do século XVII, as rivalidades européias foram trazidas para a Ásia, o que nas palavras de Marta Borges seria a "dimensão ultramarina" dos conflitos de poder entre as potências ocidentais.

Assim, para além do mundo mediterrânico, a modernidade se apresenta pela ambivalência da negociação política. As fronteiras entre Leste/Oeste, Islã/Cristandade, senhor/vassalo e viajante/soldado se perdem na liquidez dos limites marítimos que, devido à sua porosidade política, econômica e cultural, também tornam ambivalente qualquer separação entre negociação e conflito no século XVI.

\footnotetext{
${ }^{54}$ Marta da Graça Burnay Pereira de Almeida Borges. Um Estreito Globalizado: a luta por Ormuz (1622) e a globalização das relações internacionais no período moderno. Dissertação de Mestrado. Instituto Superior de Ciências do trabalho e da Empresa. Lisboa, 2008. 127 pgs.
} 


\subsection{A Modernidade simbiótica: o Norte da África}

A fronteira natural entre o Norte da África e o Sul da Europa não passou de mero obstáculo facilmente superável pela formação de uma cultura religiosa islâmica que, apesar de pequenas diferenças doutrinais, mantinha-se coesa em razão do fluxo migratório constante entre os povos dessas duas regiões. A porção ocidental do Mar Mediterrâneo jamais foi considerada um impedimento natural para que os califados e reinos islâmicos da região se relacionassem ou mesmo se fundissem sob o domínio de uma única dinastia. Essa relação intensa entre Europa e África islâmicas foi favorecida, sobretudo, pela constante atividade de viajantes árabes que circularam por esses territórios, registrando suas experiências em relatos preservados pela tradição cultural islâmica. A grande contribuição desses textos de viagens está no fato de que dificilmente eles sustentam uma condição narrativa única. Se no jogo político mediterrâneo as fronteiras entre os reinos e califados são porosas, a distinção entre narrativa histórica, geográfica e literária também não se sustenta nos relatos deixados pelos árabes sobre o Norte da África.

O que impressiona nesse contexto político e cultural do mediterrâneo islâmico é a constância com que, desde o século IX, os árabes produziram registros sobre viagens feitas ao e no continente africano. Para citar os mais emblemáticos, al-Ya'qubi, no século IX; al-Mas‘udi e Ibn Hawqal, no século X; al-Bakri, no século XI; al-Idrisi e alGarnati no século XII; Yaqut, Ibn Shahid, Ibn al-Wardi e Ibn Jubayr, no século XIII; Abu al-Fida (Abulfeda), al-Umari, Ibn Battuta e Ibn Khaldun, no século XIV.

A discussão sobre a classificação desses relatos tem desafiado os historiadores que se debruçam sobre as narrativas de viagens dos árabes. Ao invés de considerá-las a partir de uma divisão entre categorias disciplinares como "história", "geografia" e "literatura", muitos analistas preferem manter o termo árabe "riḥla" (رحلة), em uma definição próxima de "relato de viagem". O conceito de "riḥla" é retirado do Alcorão para nomear um tipo de produção literária específica que ressalta a descrição do itinerário que um viajante faz, acompanhado de comentários políticos, econômicos, históricos, sociológicos, ou de qualquer natureza, enfim, desde que constatável pela observação humana. ${ }^{55}$ Partes consideráveis desses relatos sobre terras estrangeiras

\footnotetext{
55 "Un genre littéraire naquit des voyages qu'accomplirent ces Occidentaux andalous et maghrébins : la riḥla, journal de voyage avec descriptif de l'itinéraire poursuivi, aller et retour, accompagné d`observations politiques, économiques, historiques, sociologiques... ». Paule Charles Dominique (trad.).
} 
possuem um caráter "enciclopédico" justamente por serem pautados por uma definição de conhecimento geográfico que não se limita à descrição do espaço físico, mas se afirmam como recapitulação de conhecimentos teóricos adquiridos tanto por viajantes predecessores, quanto pelo olhar do próprio autor.

Como o território africano era uma região de constante expansão das pretensões políticas, econômicas e culturais dos árabes, a rị̣la se desenvolveu com grande força nos textos dos viajantes árabes que percorreram desde a Idade Média as terras do continente. O caminho seguido por esses viajantes foi marcado pela tensão política que, até a chegada dos otomanos à região no século XVI, manteve o Norte da África como espaço de ascensão e decadência de dinastias regionais que tentavam equilibrar as influências culturais islâmicas e berberes. Nesse contexto, o "Magreb" (المغرب) teve a presença árabe e berbere combinadas já no século XI com a formação da dinastia almorávida, que se originou como um movimento de reforma religiosa no atual território do Saara Ocidental, expandindo-se rapidamente até conquistar grande parte da Península Ibérica. Com a mesma ligeireza com que se estendeu, porém, a dinastia almorávida se desintegrou, não conseguindo manter-se por um século completo. $\mathrm{O}$ rigorismo religioso que levou os almorávidas ao poder não pôde ser escorado pela dinastia, que crescia em uma velocidade maior do que sua capacidade de sustentar-se. Dessa forma, já no século XII a junção de berberes das montanhas Atlas com árabes muçulmanos descontentes com o afrouxamento da aspereza religiosa dos almorávidas levou à ascensão de uma nova dinastia na região, os almoadas, que se mantiveram no poder entre 1130 e 1269.

Na Península Ibérica, a desagregação do domínio almoada teve início com a vitória dos cristãos da Espanha, na já citada batalha de Las Navas de Tolosa, em 1212. De acordo com Ivan Hrbek, "a desintegração do império começou lentamente logo após a batalha, ganhando, em seguida, rapidez e intensidade crescentes: o território controlado efetivamente pelos soberanos almoadas tornava-se cada vez mais reduzido,

Voyageurs arabes: Ibn Fadlan, Ibn Jubayr, Ibn Battuta et un auteur anonyme. Paris : Éditions Gallimard, 1995, p. XXII.

${ }^{56}$ Magreb ou Magrebe: palavra árabe para definir no interior do império islâmica sua porção ocidental. O Magreb (e sua versão estendida, o Grande Magreb) corresponde aos atuais territórios de Marrocos, Saara Ocidental, Mauritânia, Argélia, Tunísia e Líbia. O termo foi incorporado ao vocabulário científico pelos franceses após a presença colonial dos mesmos na região. Na língua árabe contemporânea, a palavra alMagreb é utilizada para nomear o atual Reino do Marrocos. 
processo este que teve origem na parte ocidental do Magreb (Ifrikiya) ao mesmo tempo que em al-Andaluz (Espanha muçulmana)...". 57

Se externamente a pressão sobre a dinastia almoada era crescente, na política interna o cenário era também instável. A iminente insurreição de grupos internos descontentes com o poder almoada minava a já frágil coesão política dessa dinastia. Os árabes, berberes, e até os habitantes de cidades fortes como Marrakesh pressionavam os almoadas por reformas sociais profundas, ao que estes respondiam com uma repressão militar constante. A necessidade de manter um exército atuante interna e externamente fez com que os almoadas passassem a depender de soldados mercenários, destruindo o espírito de luta militante que sempre caracterizou as tropas religiosas dessa dinastia. Sem apoio interno, sofrendo pressão dos cristãos da Espanha e sem legitimidade religiosa, a dinastia almoada foi minguando até a queda de seu último califa, al-Wathik, em 1269.

O fim da dinastia almoada levou o Magreb a uma espécie de fragmentação política, que constituiu na região três reinos independentes e adversários entre si. Ainda que cada um desses reinos tivesse uma trajetória própria, enfrentaram a pressão crescente dos reinos cristãos europeus que, nos planos militar, econômico e político, rivalizavam no Mediterrâneo com as dinastias islâmicas recém instauradas no Norte da África. Essas dinastias que surgiram com a desintegração dos almoadas foram: os Hafsidas (الحفصيون), os Marínidas (مرينيون), e os Zaiânidas (زيانيون).

Os Hafsidas, apesar de romperem com a dinastia almoada, não renegaram completamente sua doutrina. $\mathrm{O}$ argumento principal de ascensão dessa nova dinastia era justamente a restauração da ortodoxia religiosa abandonada pelos almoadas com o tempo. O território dessa dinastia era formado pela região meridional do Magreb, e caminhou em direção à Tripolitânia (entre os atuais territórios da Tunísia e da Líbia).

Com a estabilidade política conquistada depois da desagregação da dinastia almoada, os Hafsidas experimentaram um crescimento econômico que transformou sua capital, Túnis, em um porto mediterrâneo estratégico para mercadores estrangeiros, inclusive cristãos. A prosperidade econômica da dinastia não garantiu, com o tempo, o fim das querelas internas. Mesmo sedimentando sua soberania sobre a África setentrional, aos poucos a dinastia Hafsida teve que aprender a conviver com um foco crescente de instabilidade interna: a chegada de imigrantes e refugiados islâmicos da

\footnotetext{
${ }^{57}$ Ivan Hrbek. A desintegração da unidade política do Magreb. (IN) Djibril Tamsin Niane (ed.). História Geral da África IV: África dos séculos XIII ao XVI. UNESCO/MEC - Brasil, 2010, p. 97.
} 
Península Ibérica expulsos da região pelos reinos cristãos. A rivalidade entre líderes vinculados aos antigos almoadas e os recém-chegados de al-Andaluz começou a manifestar-se no reinado de al-Mustansir (1249 e 1277), o que fez com que esse período marcasse, ao mesmo tempo, o apogeu econômico dos Hafsidas pelo comércio com a Europa cristã e o início de contendas entre os grupos que formavam a sua sociedade.

O principal desafio de al-Mustansir ocorreu em 1270, quando Luís IX, rei da França, empreendeu uma cruzada contra Túnis. As hipóteses sobre os motivos que levaram os franceses a esse ataque não são claras, mas os resultados da cruzada são incontestáveis: ao final, o despreparo dos franceses e uma epidemia contraída em Cartago deram a vitória incontestável aos Hafsidas ${ }^{58}$. A despeito de todos os transtornos gerados pela cruzada francesa de 1270, as relações comerciais entre os Hafsidas e a Europa cristã se mantiveram florescentes. Somente com a morte de al-Mustansir é que a estabilidade dos Hafsidas começou a se deteriorar, principalmente porque, sem uma força política de prestígio, lutas internas entre os membros da dinastia, revoltas árabes e dissidência de líderes locais, a unidade territorial e o apogeu econômico dos Hafsidas foram minados.

A partir do século XIV a história da dinastia Hafsida variou entre momentos de restauração da unidade da dinastia e a fragmentação de seu poder em pequenos reinos locais independentes. O grande desafio dos líderes políticos Hafsidas era tentar equilibrar os interesses dos três principais grupos que compunham a sociedade Hafsida: árabes, almoadas e andaluzes. Com certa fragilidade, a dinastia Hafsida manteve-se ativa até o início do século XVI, quando a disputa entre Espanha cristã e Império Otomano pela hegemonia no Mediterrâneo não permitiu a manutenção de sua independência política e econômica. O mundo mediterrânico se transformava em uma velocidade impossível de ser acompanhada por uma fraca dinastia incrustada entre dois gigantes imperiais que reivindicavam o domínio sobre o comércio marítimo do Mediterrâneo. O mundo parecia grande demais para a pequena dinastia de Túnis.

\footnotetext{
58 "Alguns anos mais tarde, al-Mustansir teve a oportunidade de aumentar sua reputação no mundo muçulmano, graças aos efeitos da Cruzada conduzida contra Túnis por Luís IX, rei da França, em 1270. Não são muito claras as razões para essa Cruzada tardia, e existem numerosas interpretações a respeito. Aventou-se a hipótese de que os franceses teriam sido atraídos pela prosperidade da Ifrikiya, ou ainda, conforme relata Ibn Khaldun, de que comerciantes da Provença, diante da dificuldade de obterem o retorno do dinheiro que haviam emprestado aos tunisianos, teriam insistido para que se fizesse a expedição. Por sua vez, São Luís (Luís IX) acreditava que al-Mustansir queria se converter ao cristianismo; ademais, tencionava usar a Ifrikiya como base para futura campanha contra o Egito. A expedição foi mal preparada - até mesmo Carlos de Anjou, rei da Sicília, irmão de São Luís, só foi informado da empresa no último instante. Os cruzados desembarcaram em Cartago, mas, passadas poucas semanas, uma epidemia devastou seu campo, matando o próprio rei”. Idem, ibidem, pp. 101-102.
} 
Simultaneamente aos Hafsidas surgiu na região do atual Marrocos uma dinastia favorecida pelo enfraquecimento dos almoadas: os Marínidas. Sua expansão rápida alicerçou-se na imposição de sua hegemonia política sobre agricultores locais e até mesmo, sobre cidades importantes, como Fez, Marrakesh e Rabat. Entretanto, ao contrário de outras dinastias que se instauraram no Magreb, os Marínidas não tinham uma motivação religiosa para a sua expansão, o que tornou mais lenta sua conquista territorial sobre a região. Mesmo sem uma base religiosa que os legitimasse, os Marínidas foram rapidamente identificados como sucessores dos almoadas, principalmente por repetirem o feito de chegar até a Península Ibérica.

A principal característica que separava os Marínidas das demais dinastias do Magreb era o fato de que esse reino sofreu mais fortemente o impacto da chegada de árabes nômades em suas terras, perdendo o caráter berbere comum a grupos como os almorávidas e almoadas. Assim, absorvendo o fluxo de árabes nômades, a estrutura social da dinastia Marínida foi profundamente alterada, já que cada vez mais a sociedade local se dividia em nômades, citadinos e montanheses. ${ }^{59} \mathrm{Um}$ dos desafios de se manter uma estrutura social predominantemente nômade era como fazê-los abrir mão do nomadismo para engrossar as fileiras do exército dinástico. Com os nômades árabes gozando de certa autonomia política, ainda que submetidos nominalmente aos Marínidas, restava ao exército depender de mercenários não necessariamente fieis aos seus comandantes.

Outro fator social que desestabilizou a sociedade Marínida foi a vinda regular de imigrantes andaluzes expulsos pelos cristãos espanhóis. O estilo de vida mais sofisticado dos membros das cortes de al-Andaluz afetou as grandes cidades Marínidas, introduzindo aspectos arquitetônicos, literários e artísticos inovadores às rústicas regiões do Marrocos. ${ }^{60}$ Nesse contexto de esplendor cultural, a cidade de Fez foi mais diretamente envolvida pelas mudanças trazidas pelos imigrantes árabes, fazendo com que a cidade se transformasse no principal centro cultural do Marrocos, em substituição

\footnotetext{
59 "Esse processo de expansão dos árabes nômades também teve aspectos negativos: enquanto o domínio dos nômades crescia incessantemente, diminuía o dos agricultores: campos, jardins e florestas eram transformados pelos nômades em áreas de pastagem. O desenvolvimento do nomadismo contribuiu, em grande parte, para cristalizar a estrutura social que iria caracterizar o Marrocos nos séculos seguintes: a divisão da população em nômades, citadinos e montanheses". Idem, Ibidem, p. 108.

${ }^{60} \mathrm{O}$ afluxo de imigrantes árabes de al-Andaluz ao Norte da África permaneceu intenso mesmo após a queda da dinastia Marínida; fato que será importante para o contexto histórico do principal personagem desse trabalho: João Leão, o Africano, que será melhor discutido no próximo capítulo.
} 
a Marrakesh, já em franca decadência. Esse é um momento em que as cidades da região passaram a se organizar em torno de uma universidade ou madrasa (مدرسة)

A já citada vinda de imigrantes árabes andaluzes ao território Marínida impunha a necessidade dos mesmos encararem o desafio de conter a expansão cristã na Península Ibérica. Uma reação ao avanço cristão espanhol no Sul da Península Ibérica parecia ser uma oportunidade para o alargamento das fronteiras do reino Marínida. Por isso, já em fins do século XIII, os Marínidas iniciaram uma série de campanhas ao território europeu com o intuito de frear o progresso militar dos cristãos. As vitórias dos Marínidas na Península Ibérica garantiram uma sobrevida maior ao reino de Granada, que passou a servir de escudo para a chegada dos cristãos espanhóis ao Norte da África. O confronto desses dois reinos pelo domínio do Sul da Península Ibérica chegou até ao embate marítimo, com a vitória Marínida sobre a esquadra espanhola em 1279.

Após o momento de apogeu da dinastia em fins do século XIII, os Marínidas experimentaram um período de decadência devido a disputas políticas internas. A região sahariana do reino foi reivindicada por membros dissidentes da família dominante que controlavam o comércio do Sul do Marrocos. A rebelião familiar somente cessou com a ascensão ao poder de Abu al-Hassan, em 1331, responsável por nova coesão interna na elite política Marínida. A consequência central desses anos de lutas intestinas fora a impossibilidade dos Marínidas manterem uma política agressiva frente aos europeus cristãos na Península Ibérica, que só pôde ser retomada com Abu al-Hassan. ${ }^{62}$ Sob o controle do novo soberano, a dinastia Marínida uniu forças com o Reino de Granada com o intuito de eliminar definitivamente as pretensões cristãs espanholas em alAndaluz. Apesar das intenções dos Marínidas de não permitirem qualquer avanço cristão, uma sucessão de derrotas militares levou o soberano islâmico a desistir de seu projeto de permanência em terras andaluzas. Sem possibilidade de se expandirem ao Norte, os Marínidas direcionaram suas forças militares contra os Hafsidas, até a conquista de Túnis, em 1347.

Entretanto, as conquistas de Abu al-Hassan na Tunísia foram seguidas de seu declínio no poder. Os esforços empreendidos para deslocar tantos recursos militares e

\footnotetext{
${ }^{61}$ Espécie de escolas islâmicas voltadas, sobretudo, para o ensino do conhecimento religioso.

62 "Abu al-Hasan foi, sem dúvida, o maior dos sultões marínidas. Pouco após sua ascensão ao poder, reafirmou a autoridade de Fez sobre o Marrocos meridional, pôs fim aos conflitos internos e retomou a política de conquistas. Durante a primeira metade do reinado, consagrou todos os esforços ao restabelecimento da soberania muçulmana na Espanha, o que se tornava premente, pois em 1337 o rei de Castela retomou as hostilidades contra Granada. Em 1333, o exército marínida atravessou o estreito de Gibraltar e conquistou Algeciras". Idem ibidem, p. 109.
} 
econômicos do Norte para o Leste levaram a dinastia a um esgotamento inevitável. Somada a essa crise econômica, a falta de habilidade do soberano em equilibrar os interesses de líderes locais em todo o território Marínida minou a união interna que sustentava a própria dinastia. O resultado desse cenário caótico foi a progressiva destruição dos Marínidas até o século XV. Com o tempo, o poder político da dinastia foi fragmentado, cabendo agora a lideranças locais que não souberam se organizar contra uma ameaça conjunta crescente: as incursões portuguesas sobre o Marrocos, tanto na parte mediterrânea como na porção atlântica desse território. $\mathrm{O}$ resultado desse cenário de desagregação do legado político dos Marínidas foi a ascensão gradual dessas lideranças locais conhecidas como Wattásidas. O último sultão Marínida, Abd al-Haqq II, é destronado em 1465 por uma revolta popular e um período de instabilidade política se instaura, permitindo a atuação dos líderes locais acima citados. Enfim, em 1472 o wattásida Mohammed ach-Chaykh concentra poderes no Reino de Fez e funda sua frágil dinastía que perdura até 1554 .

O último reino islâmico com dimensões significativas no Norte da África nesse período foi a dinastia Zaiânida, sediada na atual região da Argélia e que perdurou até 1554. Uma das explicações para a longa sobrevivência desse reino é a de que, desde a sua formação, a dinastia Zaiânida se viu obrigada a defender-se de forças externas vizinhas, principalmente dos Marínidas. Além das constantes incursões de rivais próximos, os Zaiânidas tiveram que enfrentar problemas econômicos profundos motivados pelo fato de que suas terras eram as menos férteis do Norte da África, e de que a maioria da sua população era nômade, sem vinculo com a terra e sem tradição agrícola expressiva. Parte da população nômade exercia o trabalho pastoril e enfrentava pressões dos árabes do Sul, que tomavam rotineiramente suas pastagens. Essa situação de fragilidade política e econômica permitiu que a dinastia Zaiânida fosse, em muitos momentos, uma espécie de reino satélite de poderes adventícios.

O que fazia da dinastia Zaiânida alvo da cobiça estrangeira era a relevância do porto de Tlemcen no comércio marítimo do Mediterrâneo. A localização privilegiada dessa cidade, entre a Europa, o Magreb e o Machreq (مشرق) ${ }^{63}$, fez de seu porto um dos centros econômicos do período, competindo com outras cidades importantes como Orã, Bidjaya e Túnis. Na segunda metade do século XIV, o território dos Zaiânidas chegou a ser ocupado pelos Marínidas e sofreu invasões promovidas pelos árabes do Sul. Nesse

\footnotetext{
${ }^{63}$ Palavra árabe para definir no interior do império islâmico sua porção oriental.
} 
momento, a necessidade de se instituirem negociadores entre os árabes invasores e o soberano Zaiânida fez com que os imigrantes andaluzes que habitavam Tlemcen assumissem um papel decisivo na trajetória histórica da dinastia. Devido a querelas com os reinos cristãos ou mesmo a embates internos em seus reinos de origem, os refugiados políticos islâmicos de al-Andaluz chegavam ao Norte da África dispostos a servir ao soberano local em troca de proteção social. Muitos viajantes árabes tiveram esse destino, entrando em contato com a sociedade magrebina mediante a ação imponderável do cenário político do Mediterrâneo, que contribuiu para a formação de uma visão cultural simbiótica sobre o mundo moderno nesses "viajantes-imigrantes-refugiados". Ainda que o objetivo central desse trabalho seja, entre outras coisas, analisar o ambiente cultural ambivalente do Mediterrâneo no século XVI, cabe mencionar casos anteriores que se assemelharam em alguns pontos ao de João Leão Africano. Dentre os viajantes árabes que tiveram a África como cenário de seus relatos e utilizaram essa experiência para refletir sobre o contexto cultural de sua época, encontra-se o historiador Abū Zayd 'Abdu ar-Raḥman bin Muḥammad bin Ḩaldūn Al-Ḥaḍramī, ou, em transcrição simplificada, Ibn Khaldun. ${ }^{64}$

\subsection{As cinzas do conhecimento: Ibn Khaldun, João Leão Africano e a história árabe simbiótica}

Nascido na atual região da Tunísia, Ibn Khaldun era de origem andaluza, pois sua família teve que fugir de Sevilha quando o Reino de Castela invadiu a cidade em meados do século XIII. Como o conflito entre reinos cristãos e muçulmanos no Mediterrâneo se arrastou por séculos, Ibn Khaldun pode ser entendido como um homem marcado pelo contexto de enfrentamento por supremacia político-comercial e de simbiose cultural que envolvia toda a Europa meridional, o Norte da África e a costa do Levante na Ásia.

É nesse cenário de intercâmbio cultural somado a alianças e rivalidades militares entre povos distintos que Ibn Khaldun começou a construir suas reflexões sobre o mundo. Em um momento em que fidelidades religiosas perdem espaço para interesses comerciais, o fluxo de informação produzido pelo contato entre Islã e Cristandade

\footnotetext{
أبو زيد عبد الرحمن بن محمد بن خلدون Em árabe
} 
construía a necessidade de se refletir sobre uma história mais completa, que não abandonasse padrões religiosos de se conceber o tempo histórico, porém reforçando o papel da ação humana. Alguns autores, como Miguel Cruz Hernández, afirmam que essa construção de uma reflexão histórica e filosófica do mundo é própria do ambiente de circulação cultural alimentada pelo contexto mediterrânico já no século XIV, pois "esto ha hecho que se haya comparado la actitud de Ibn Jaldun con la del hombre occidental renacentista, aunque sin razón suficiente, ya que Ibn Jaldun sigue siendo el tipo clásico del 'sábio’ musulmán...". ${ }^{65} \mathrm{O}$ que Miguel Cruz Hernández ressalta não é um vínculo efetivo de Ibn Khaldun com o pensamento ocidental renascentista, mas o impacto com que as relações entre Europa e Norte da África atingiam os pensadores islâmicos.

No interior da dinastia Hafsida em pleno século XIV, Ibn Khaldun teve uma educação esmerada, que mesclava estudos do Alcorão com conhecimentos variados como matemática, lógica, jurisprudência islâmica (fiqh, فقه), poesia e filosofia. Uma formação intelectual tão abrangente permitiu que Ibn Khaldun atuasse como funcionário de diversos governantes, revivendo uma tradição familiar de servir a líderes locais e de fazer parte de uma elite burocrática. Após conquistar certa tranquilidade econômica como funcionário dos soberanos Hafsidas, Ibn Khaldun viajou para al-Andaluz tentando, entre outras coisas, aproximar-se de suas origens. Ao chegar à Espanha Islâmica em pleno século XIV, a Sevilha de seus antepassados já se encontrava sob o domínio consolidado do reino cristão de Castela, o que o levou a fixar-se em Granada. A educação apurada de Ibn Khaldun permitiu que, ao se estabelecer em Granada, o jovem pensador árabe se aproximasse do líder granadino Ibn al-Khatib, que assim como Ibn Khaldun foi político, historiador, poeta e filósofo. Por essas relações de proximidade com figuras políticas locais, o imigrado africano não encontrou resistência para fazer parte da elite administrativa de Granada. Ibn Khaldun chegou a exercer funções importantes no governo do reino, ficando responsável até mesmo por missões diplomáticas a reinos cristãos fronteiriços.

Porém, uma ascensão social rápida como essa não deixaria de suscitar intrigas palacianas. Por inimizades próprias de um circuito de prestígio como o da corte de Granada, Ibn Khaldun volta ao Norte da África tentando se encontrar em um mundo cada vez mais marcado por disputas políticas que não interessavam a quem dedicava

\footnotetext{
${ }^{65}$ Miguel Cruz Hernández. La Filosofía Árabe. Madri: Revista de Occidente. s/d. p. 380.
} 
parte de sua vida à reflexão filosófica. Por isso, entre 1375 e 1379, Ibn Khaldun retirouse para Qalaat Ibn Salama, uma pequena vila na atual região argelina de Tiaret. Esse é o período em que o autor começa a redigir a primeira parte (al-Muqaddima, المقدمه ) de sua principal obra, a volumosa "História Universal" ou, em tradução literal, "Livro das lições e registro do sujeito e do predicado a respeito dos dias dos árabes, dos persas e dos berberes e de quem lhes foi contemporâneo dentre aqueles que detiveram o poder maior" ( كتاب العبر وديوان المبتدا والخبر في ايام العرب والعجم والبربر ومن عاصرهم من ذوي السلطان (الاكبر).

Em seguida, na etapa final de sua vida, Ibn Khaldun viveu no Cairo, onde concentrou seus esforços em adquirir reconhecimento intelectual. Deixou de esforçar-se por cargos de relevância política para buscar a fama atrelada ao cargo de juiz supremo ou de professor de diferentes universidades. No Cairo, vê-se um Ibn Khaldun mais "contemplativo"; dedicando parte considerável do seu tempo a leituras e à redação de textos científicos que eram expostos em suas aulas na Universidade de al-Azhar, ${ }^{66}$ a primeira do Cairo.

Os pesquisadores árabes que estudam a vida e a obra de Ibn Khaldun, como por exemplo Mahdi Mohamed-Saleh Rashid, ${ }^{67}$ detalham sua vida e seu desenvolvimento intelectual a partir de quatro etapas distintas: 1) os estudos do jovem Ibn Khaldun no Norte da África; 2) suas aventuras políticas na mesma região; 3) etapa de solidão e dedicação exclusiva à sua obra; e 4) etapa final em que leciona, atua como juiz supremo no Egito e dedica-se a complementar sua obra "História Universal".

A forte personalidade e a erudição de Ibn Khaldun permitiram seu convívio com distintos interlocutores de todo o mundo islâmico, o que garantiu em suas obras uma interpretação pluralista da experiência humana. Essa visão aberta da história, da política e da sociedade de sua época foi construída a partir de uma formação intelectual influenciada por professores de al-Andaluz, que incorporavam em seus ensinamentos a experiência cultural heterogênea própria da Península Ibérica dominada pelos árabes. Isso não significa que em al-Andaluz não houvesse tensões entre as diferentes matrizes culturais daquele momento, mas apenas reforça que até mesmo as crises de convivência

\footnotetext{
66 - Universidade de al-Azhar, fundada como escola xiita de teologia no século X, pelos califas fatímidas, e transformada em instituição sunita no século XII. É considerada atualmente uma das universidades mais importantes do mundo islâmico.

${ }^{67}$ Ver Mahdi Mohamed-Saleh Rashid. Fundamentos y Análisis Del pensamiento histórico, social y político de Ibn Jaldún. Tese de doutorado. Universidad Pontifica de Salamanca, 2009.
} 
entre povos distintos se refletiram diretamente na personalidade e, sobretudo, no pensamento de Ibn Khaldun.

A partir dessas características da vida de Ibn Khaldun, pode-se melhor compreender o tipo de conhecimento e de "ciência" elaborados pelo pensador norteafricano. Mais do que descrever uma espécie de teoria epistemológica, o que se pretende é encontrar certa unidade nas concepções historiográficas de Ibn Khaldun, reconstruindo as inquietações do autor e suas questões de ordem cognitiva que tanto refletem a cultura simbiótica do Mediterrâneo. Nessa perspectiva, há um conceito no pensamento de Ibn Khaldun que melhor sintetiza o caráter inovador de seu olhar sobre a História: a idéia de "Umrān" (عمران), palavra que na raiz possui o semantema de "construir", inicialmente traduzida como "cultura" ou "civilização". Ao contrário da concepção recorrente de "civilização" como contraposição à "barbárie", o conceito islâmico de "Umrān" refere-se à existência mesma do ser humano no mundo, ressaltando a ordem instituída por Deus para a sua sobrevivência. Destaca-se, portanto, uma definição de "civilização" como o conjunto das manifestações dessa ordem humana ou sócio-política, vivida principalmente no espaço urbano, ainda que haja uma civilização primordial ligada à vida nômade do deserto. ${ }^{68}$ A História teria por finalidade conhecer o estado social do homem e sua dimensão humana, somente passível de ser detectada pela natureza do "Umrān" de determinado povo. Por isso, para Ibn Khaldun, a História é, acima de tudo, a ciência da civilização.

No interior das considerações de Ibn Khaldun sobre o conceito de "Umrān" e sua relação com uma espécie de "ciência histórica", está presente uma discussão epistemológica própria do todo o pensamento árabe-islâmico. Os gramáticos árabes anteriores ao século XIV incorporaram em seus textos uma crítica ao conhecimento que produziam, elaborando obras próximas a um tipo de "filosofia da sintaxe" que refletiam uma preocupação constante com os fundamentos científicos dos seus trabalhos. Nesse mesmo caminho, os juristas e filósofos islâmicos também seguiram essa tendência, o que mostrava a Ibn Khaldun que sua inquietação epistemológica deveria produzir uma

\footnotetext{
68 "Desde este punto de vista, el discurso epistemológico jalduniano habrá de ser, por fuerza, un discurso ambivalente que aborde a través de su objeto particular e inmediato otro más amplio, tomando de este último sus principios y presupuestos. Esto explica el que, una vez tratada la cuestión de 'los tipos de hombres dotados de la percepción de lo invisible' y de 'las ciencias y sus géneros' en cuanto que 'manifestaciones de la civilización' (es decir, como fenómenos sociales), Abenjaldún aborde la relación entre la tradición y la razón, entre la filosofía y la religión, tomando de esta relación, tal como él la concibe, los principios gnoseológicos de los que parte al estudiar los aspectos espiritual e intelectual de la civilización humana". Mohamed Ábed Yabri. El legado filosófico árabe: Alfarabi, Avicena, Avempace, Averroes, Abenjaldún - Lecturas contemporáneas. Madri: Editorial Trotta, 2006. $2^{\text {a }}$. Edição, pp. 330-331.
} 
definição científica de História alicerçada em um conceito explicativo como o de "Umrān”. A partir dessa relação entre a ciência e sua justificativa epistemológica, Ibn Khaldun moldou uma maneira moderna de se conceber a História, apresentando-a tanto vinculada a uma filosofia reflexiva da experiência humana no tempo quanto como uma forma de conhecimento específica.

O caráter inovador do pensamento histórico de Ibn Khaldun se mostra pelo fato de que, em plena passagem do século XIV para o XV, o autor norte-africano já expunha sua intenção de fundar uma nova "ciência", fazendo da História uma verdadeira área moderna de conhecimento. Nas palavras de Mohamed Ábed al-Jabri:

“La Introducción a la historia universal de Abenjaldún se distingue de todas las demás, por tanto, en que no pretende fundamentar un punto de vista parcial o exponer un método. Se trata de algo más. Se trata de fundar una ciencia nueva; de hacer que la Historia pase de ser un arte a convertirse en una verdadera disciplina científica". 69

Para Ibn Khaldun, destarte, se a História fosse apenas arte estaria limitada à condição de simples relato épico ou lendário de grandes feitos, sem zelar pela objetividade e racionalidade próprias de um conhecimento científico. Para não ser reduzida a um estilo artístico-literário, a História deve partir do exame, da averiguação e da análise minuciosa das causas para poder explicar a maneira como se estabelecem os Estados e nações, por exemplo, bem como as artes, as ciências e tudo o que deriva da existência da organização política humana. Por isso, a História deve explicar o surgimento, retrocesso e desaparecimento das "civilizações". Para Ibn Khaldun, a História como conhecimento é, sobretudo, o estudo atento dos eventos históricos fundamentais, assim como dos elementos políticos, econômicos, culturais e sociais atrelados a tais eventos.

A proposta dessa nova concepção de conhecimento histórico pode ser entendida como ampliadora do objeto de análise da História, pois exige do historiador certa sensibilidade e capacidade de observação para mapear princípios específicos das experiências humanas, começando pela organização política e estendendo o olhar do pesquisador para diferenças de usos, costumes, religiosidades e qualquer outra forma de manifestação do princípio civilizador do homem.

\footnotetext{
${ }^{69}$ Idem ibidem, p. 333.
} 
Se para Ibn Khaldun a História não é arte, ela também não se fundamenta no mesmo tipo de princípio que constitui o pensamento religioso, ou "kalām" (كلام). ${ }^{70}$ No interior dessa discussão sobre a raiz epistemológica do pensamento religioso, Ibn Khaldun afasta-se da História para definir dois padrões distintos de ciências relacionadas à religião: o "kalām", submetido ao papel ativo do intelecto humano; e a mística e a interpretação dos sonhos, submetidas à função da alma na construção desse conhecimento. $^{71}$

Sobre o "kalām", Mohamed Ábed al-Jabri afirma que Ibn Khaldun o define como “... la ciencia que suministra los medios para probar las creencias religiosas mediante argumentos racionales y refutar las innovaciones que se apartan de la doctrina seguida por los primeros musulmanes y los observantes de la Sunna" ${ }^{\text {"72 }}$. Desse modo, o intelecto constitui a principal ferramenta interpretativa do "kalām", que metodologicamente deve separar a tradição ortodoxa religiosa daquilo que no Islã sunita é conhecido como "inovação", ou "bid"a" (بدعة). Para a Sunna, “inovação" é tudo aquilo que não se encontra atestado no Alcorão e no Hadith $^{73}$. Rotineiramente, as inovações são consideradas adaptações de uma crença ou prática islâmica original que, por afastar-se da mensagem original do Profeta são vistas como uma corrupção dos princípios religiosos. Para Ibn Khaldun, a refutação racional dessas inovações é uma atividade intelectual específica do conhecimento religioso, que pelo uso de sua razão particular confere ao "kalām" uma distinção metodológica e epistemológica em relação às demais ciências como a jurisprudência islâmica, e principalmente, a História.

Mas as distinções entre História e pensamento religioso não se esgotam nessas características. Enquanto a História tem como objetivo detectar o caráter civilizador da ação humana, o "kalām" prioriza a afirmação da unicidade de Deus, que ao contrário do

\footnotetext{
${ }^{70} \mathrm{O}$ que se entende no Islã como conhecimento religioso (كلام) não pode ser traduzido diretamente como "teologia", ainda que muitos tradutores o façam. "Kalām" é um tipo de ciência especulativa que inicialmente se fundamentava em interpretações não literais da doutrina corânica. Trata-se de uma argumentação que confere caráter científico-racional aos temas relacionados a Deus e às verdades reveladas. Assim, o "kalām" forma parte do arcabouço científico islâmico e se difere da filosofia e da História em relação à maneira como essas ciências são abordadas, já que ao contrário das demais ciências, o "kalām" é mais doutrinal (o que não deixa de caracterizá-lo como racional). Para mais definições sobre “kalām”, ver Luz Gómez García. Diccionario de Islam e Islamismo. Madri: Espasa Calpe, 2009. pp. 184185.

${ }^{71}$ A discussão sobre a mística e a interpretação dos sonhos necessita de uma reflexão apurada sobre as percepções sensíveis da alma humana, o que ultrapassa os limites conceituais da proposta original desse trabalho.

${ }_{73}^{72}$ Mohamed Ábed al-Jabri, op.cit. pp. 343-344.

73 Relato que faz menção às palavras, gestos e comportamentos do Profeta Muhammad em diversas circunstâncias. O estudo dessas práticas do Profeta é considerado uma forma de conhecimento religioso. Para mais definições sobre "Hadith”, ver Luiz Gómez García. op. cit. pp. 125-127.
} 
conceito de "civilização" não pode ser empiricamente comprovado pelo homem. A questão fundamental sobre a unicidade divina em Ibn Khaldun é que essa premissa do conhecimento religioso não pode ser apreendida inicialmente pelo intelecto. Então, o "kalām" parte de um pressuposto não determinado pela percepção sensível do homem, para, a partir dessa premissa, recorrer ao intelecto com o intuito de comprová-la ${ }^{74}$. O intelecto, voltado ao exterior, diz respeito ao ordenamento da sucessão de eventos ou dos seres sob seu domínio, sem conseguir chegar ao entendimento da Causa Primeira da experiência humana, que só pode ser apreendida pela alma. Por isso, compete à alma expressar e entender a essência mesma da fé no Deus único.

De todo modo, independentemente da natureza de cada conhecimento produzido pelo homem, Ibn Khaldun defendeu a existência de uma dimensão sócio-histórica do pensamento científico, entendendo a ação reflexiva como um fenômeno ou manifestação da vida humana. O surgimento e o desenvolvimento de uma dada ciência são determinados pela trajetória histórica da sociedade, a natureza do poder político e a ideologia dominante. Assim, como fatores condicionantes ao nascimento da reflexão científica em uma sociedade encontram-se elementos materiais como o Estado, cuja ação garante a resolução das necessidades básicas dos homens, permitindo, portanto, que seus integrantes reservem parte de seu tempo para questões críticas como a atividade intelectual. A conexão entre ciência, Estado, e o florescimento da civilização é indissociável, e comprova a existência de uma relação entre o conhecimento especulativo e a formação de uma classe social que se mantenha por meio das riquezas do Estado, dedicando-se ao pensamento reflexivo tanto a serviço da ordem política quanto para atender suas necessidades de informação. Por trás dessa conclusão sobre o desenvolvimento do pensamento científico humano encontram-se combinadas a crença de Ibn Khaldun nas circunstâncias econômicas, como fatores determinantes do desenvolvimento da História, e sua própria trajetória pessoal, já que, como funcionário de Estados islâmicos, ele pôde dedicar-se à atividade intelectual sistemática.

É claro que não se pode atribuir a um homem do mundo "medieval-moderno" como Ibn Khaldun uma definição clara do conceito de "ciência". Entretanto, não há

\footnotetext{
74 "Para ello, nuestro autor parte del objetivo fundamental de la teología, es decir, de la afirmación de la unicidad divina, aunque el concepto tiene para Abenjaldún un sentido inédito. Para él, la confesión de la unicidad de Dios consiste en "confesar nuestra incapacidad para conocer las causas de las cosas y su modo de operar, delegando la comprensión de ello en su Creador, cuya inteligencia las abarca por completo`. De este modo, mientras Algazel negaba el principio de causalidad para hacer posibles los milagros, Abenjaldún, en cambio, parte de la incapacidad del intelecto para comprender las causas - todas las causas $-\mathrm{y}$, por consiguiente, hace de la confesión de la unicidad una opción obligada." Mohamed Ábed al-Jabri. Op.cit. p. 344.
} 
como negar que para ele a História é um ramo específico e novo do conhecimento humano, mesmo em uma época muitas vezes definida pela condição estática em que as ciências se apresentavam. Isso não significa que sua época deve ser reconhecida como um momento carente de racionalidade e totalmente desprovido de desenvolvimento intelectual. O que se torna preciso considerar é que, seja no mundo islâmico, seja na cristandade, os séculos XIV e XV representaram uma ocasião de estancamento intelectual, ainda que a História de Ibn Khaldun seja a expressão mais evidente de que, mesmo em decadência política, o Islã não se entregou ao dogmatismo $\operatorname{cego}^{75}$. A circulação cultural que caracterizou esse período do mundo mediterrânico teve em Ibn Khaldun um dos primeiros sinais de que, nos séculos vindouros, a decadência política e econômica marcante em sua época não seria obstáculo para que o contato cultural entre Islã e Cristandade no Norte da África produzisse relatos sobre o mundo preocupados tanto com a opulência econômica quanto com a riqueza cultural do homem moderno.

No século XVI, a cultura simbiótica do Mediterrâneo também foi alimentada pelo fluxo de imigrantes e viajantes árabes que, flertando com a riḥla e com a História, traduziram o "Umrān" do norte da África aos cristãos ocidentais. Entre línguas, jargões e olhares, o século XVI reapresentou a África aos reinos cristãos da Europa; e coube aos árabes islâmicos o papel de cicerones dessa apresentação.

\footnotetext{
75 "En conclusion, l'Histoire, telle que la comprend Ibn Khaldoun, est bien une science; elles a les caractères qui distinguent une science d’un art ou de toute autres création de l'esprit. La brève apparition de la science historique, dans le milieu du XIVe. siècle, époque de stagnation intellectuelle, sinon de déclin, constitue un fait véritablement extraordinaire. Il importe donc de rechercher les causes de cet événement. » Yves Lacoste. Ibn Khaldoun : naissance de l'histoire passé du tiers monde. Paris : François Maspero, 1973.
} 


\section{O homem feito de terra}

De minha boca você ouvirá o árabe, o turco, o castelhano, o berbere, o hebraico,

o latim e o italiano vulgar, pois todas as línguas, todas as orações me pertencem.

Porém, não pertenço a nenhuma.

Sou apenas de Deus e da terra, e é a eles que retornarei brevemente.

(Amin Maalouf)

\subsection{O que veio do pó: Leão Africano como um homem de sua época}

O capítulo anterior teve início levantando uma questão sobre a relação entre uma pintura e sua época. As figuras retratadas nas obras eram a mesma Santa Catarina de Alexandria composta por artistas com concepções distintas de compreensão de seu tempo histórico. Nessa segunda parte do trabalho, a pergunta se desdobra em outra reflexão oportuna: O que uma pintura do século XVI pode revelar sobre os homens de sua época? Para responder esse desafio, ao invés de comparar duas telas com o mesmo tema, a melhor estratégia será concentrar-se em duas obras de um mesmo pintor que retratam personagens de época, já que o homem renascentista sintetiza, em si, a multiplicidade da experiência histórica desse período.

Em pleno século XVI, artistas, comerciantes, religiosos, e praticamente toda a sociedade mediterrânea já havia percebido que não poderia viver isolada em suas idiossincrasias. Evidentemente, as diferenças culturais entre os homens do século XVI mantiveram-se como em outros séculos, mas parecia que, com a constituição do mundo moderno (forjado por experiências como o Mercantilismo, o Humanismo, o Renascimento, a Expansão Marítima, as Reformas Religiosas, etc.), o homem desse século podia despejar suas idiossincrasias em uma constatação universal de que o comércio e a cultura transformavam figuras diacrônicas, como cristãos e muçulmanos, espanhóis e franceses, nobres e mercadores, amantes e santas, em figuras sincrônicas.

A partir dessas considerações pode-se melhor analisar as obras Ritratto di giovane romana con cesto di frutta, também conhecida como La Dorotea, e Ritratto di umanista, ambas de Sebastiano del Piombo.

A tela Ritratto di giovane romana con cesto di frutta é uma pintura a óleo sobre tela, datada aproximadamente de 1512: 


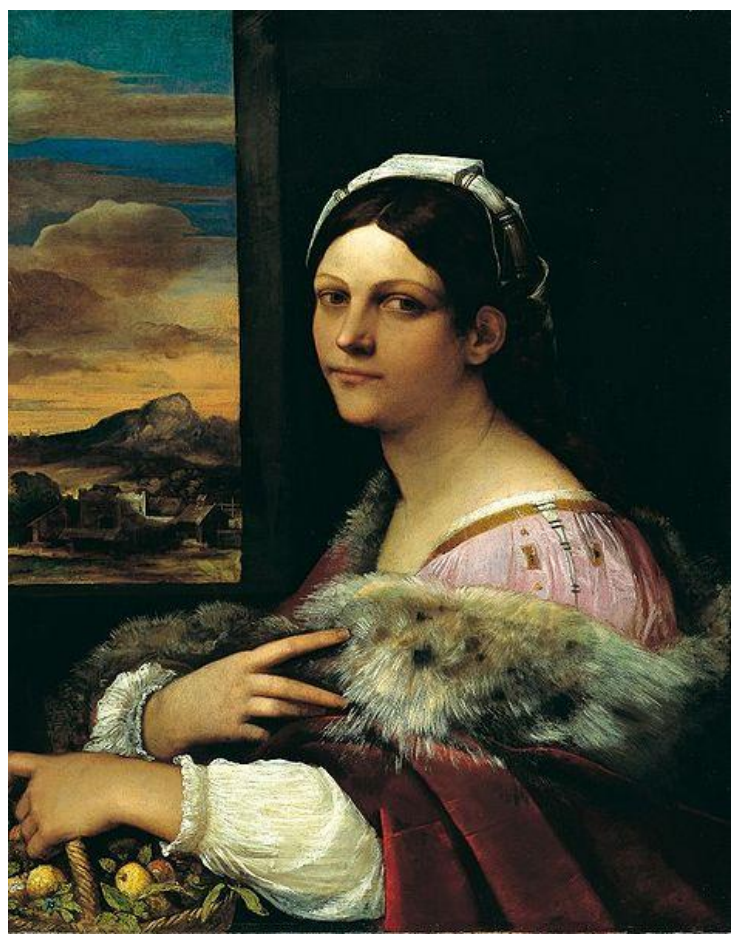

O quadro retrata uma moça pela metade de seu comprimento, com a face voltada para o espectador da tela. O nome e a origem da retratada são inicialmente desconhecidos, mas detalhes da obra, quando relacionados ao círculo cultural e comercial da Península Itálica do século XVI, podem indicar respostas que explicam tanto a identidade da personagem quanto elementos constitutivos do homem do século XVI submersos nos símbolos que a obra oculta.

Um primeiro ponto que chama a atenção de quem vislumbra a tela é a mão direita da retratada. Ela segura uma estola de pele (possivelmente de raposa ou de lince) sobre um tecido vermelho, e seus dedos médio e indicador formam sutilmente uma letra "V". Não há certeza alguma que confira um significado para a posição desses dedos. Para alguns, a letra delicadamente formada pode representar um entre dois conceitos da Antiguidade Clássica e muito populares no século XVI: "volupta" ou "virtus".

Na mitologia romana, Volupta ou Voluptas era uma das três Gratiae, ao lado de Castitas (castidade) e Pulchritude (beleza). A Volupta como personagem mitológica latina era uma figura que representava a voluptuosidade, os prazeres sensuais, o que parece indicar que a retratada na obra de Sebastiano del Piombo seja a amante de um de seus mecenas, possivelmente do banqueiro Agostino Chigi. Em contrapartida, a figura mitológica feminina da virtus remete à valentia e à coragem, e, quando negociada com 
os valores cristãos da Europa do século XVI, essa figura se define em oposição à voluptuosidade/amante, aproximando-se das concepções de virtuosidade feminina atribuídas socialmente às esposas. Desse modo, o simbolismo da letra $\mathrm{V}$ formada pelos dedos da mão direita da retratada coloca em questão o papel social dessa figura: para os partidários de Volupta, trata-se de uma amante; já os favoráveis à definição de virtus defendem a condição de esposa da personagem.

A análise da mão esquerda da retratada parece conceder certa vantagem ao argumento de que se trata não de uma esposa, mas de uma mulher virtuosa por excelência. Assomando debaixo do tecido vermelho, a mão esquerda segura uma cesta com frutas e flores, possivelmente marmelos e rosas. A cena de uma mulher portando uma cesta com esses itens é tradicionalmente atribuída à Santa Doroteia da Capadócia, uma jovem do século IV martirizada por consagrar sua castidade à Cristo. De acordo com a sua hagiografia, Santa Doroteia foi condenada à decapitação pela espada e antes da execução teria dito aos seus algozes que iria para o Paraíso, "onde sempre era primavera". Um de seus executores, Teófilo, teria ridicularizado Doroteia pedindo a ela que lhe enviasse frutas e flores do Paraíso. Após a decapitação um anjo teria aparecido a Teófilo, apresentando-se como enviado de Doroteia e trazendo-lhe frutos e flores. Ao final, o executor teria se convertido ao cristianismo, pedindo perdão a Deus e a Doroteia, sendo também decapitado posteriormente.

Com relação à obra Ritratto di giovane romana con cesto di frutta de Sebastiano del Piombo, o mais importante não é a verdadeira identidade da retratada, mas as conjecturas que revelam as múltiplas possibilidades de se definir o homem do século XVI, principalmente levando-se em consideração o seu circuito cultural e comercial, já que, por relações diversas, artistas como del Piombo, mecenas como Agostino Chigi, religiosos influentes como o Papa Leão $\mathrm{X}$ e os eruditos dos primórdios da Europa moderna estão conectados socialmente e interpretam de formas distintas a pluralidade simbólica dessa época.

Alguns anos após o término de Ritratto di giovane romana con cesto di frutta, Sebastiano del Piombo finaliza outra obra relevante: Ritratto di umanista: 


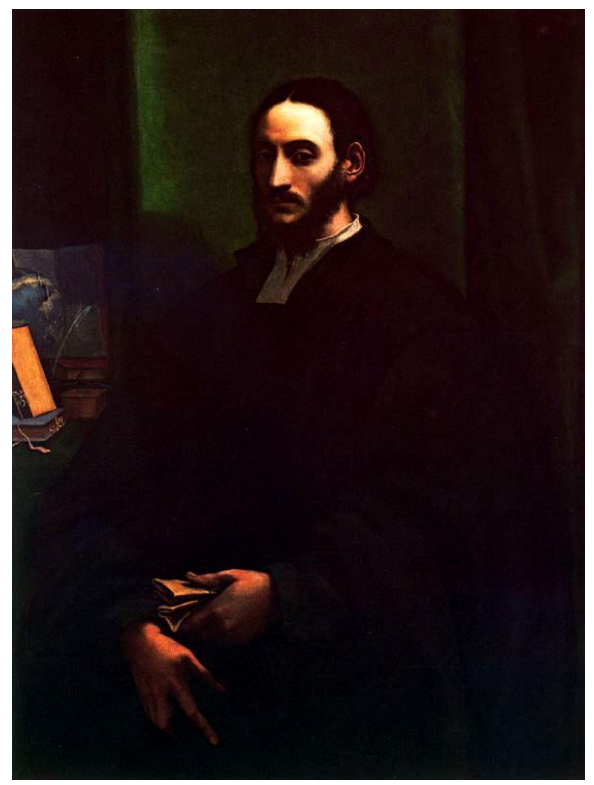

Terminada em 1519, a obra continua sendo interpretada de maneira controversa até os dias de hoje. Ao se comparar essa tela com outros importantes retratos produzidos pelo mesmo pintor, vê-se que o cenário de fundo se relaciona integralmente com o personagem retratado. Em muitas outras obras que eram definidas como retratos, Sebastiano del Piombo centralizava a figura por meio de um cenário ao fundo composto por uma janela aberta, como na já referida tela Ritratto di giovane romana con cesto di frutta.

Em Ritratto di umanista, o pintor retirou intencionalmente a marcação de fundo representada pela janela, criando uma sensação de sobriedade que serve como metáfora de um espaço voltado para a concentração, como uma espécie de quarto de estudos. Essa interpretação pode ser reforçada pela escolha do traje do personagem, já que o manto austero sugere tratar-se de um personagem erudito. Para além dessas referências percebe-se que o fundo da tela e o próprio personagem são marcados por um tom mais escuro em relação ao pequeno arranjo do lado esquerdo, única área iluminada na composição. Os olhos de quem contempla a obra são imediatamente atraídos para o arranjo, reforçando a necessidade de se exaltarem os principais objetos expostos: um globo e um livro.

A primeira pista que o pintor deixou transparecer sobre a identidade do personagem é justamente a condição ilustrada do retratado. Alguns intérpretes acreditam tratar-se de um amigo do pintor, Marcantonio Flaminio, importante poeta humanista de Serravalle, vilarejo próximo a Veneza. Entretanto, considera-se também que esse possa ser o único retrato existente de João Leão Africano, pois a obra foi 
pintada quando Sebastiano del Piombo já vivia em Roma, próximo à corte papal, e, portanto, em contato com o sábio mouro que circulava no séquito do Papa Leão $\mathrm{X}$, e, posteriormente, de Clemente $\mathrm{VII}^{76}$.

A fase "romana" de Sebastiano del Piombo é a mais produtiva de sua trajetória como pintor. Seu nome original é Sebastiano Luciani, e, somente após 1531, quando ocupou o cargo de Protetor do selo da Cúria, passou a ser chamado de "Piombo"77. Ainda que seu estilo mantivesse padrões de pintura próprios de sua formação veneziana, as influências da arte pictórica que se fazia em Roma são visíveis pela maneira como o artista utiliza a luminosidade na tela, enfatizando os contornos da figura pintada.

Mas, a questão principal que se debate sobre a tela é a identidade real do retratado. $\mathrm{O}$ argumento de que se trata de Marcantonio Flaminio é plausível, porém, não pode ser considerado totalmente adequado, devido à existência de um detalhe da obra: o globo terrestre. Se a proposta do pintor fosse apenas ressaltar o caráter erudito do homem renascentista, o livro e manto poderiam ser suficientes. Se o personagem se referisse exclusivamente a um único homem como Marcantonio Flaminio, mais de um símbolo relacionado à poesia estaria presente na tela, tais como um pergaminho ou uma coroa de louros, como tradicionalmente é retratada Calíope, musa da poesia épica e da ciência. Ao invés de destacar alguns símbolos ligados diretamente à poesia, Sebastiano del Piombo preferiu compor a representação do homem humanista por meio de um livro e um globo terrestre, o que pode ser interpretado como uma relação alegórica entre a erudição literária e o conhecimento do mundo. Por isso, pode-se ponderar que a referência do homem humanista como uma espécie de "viajante" se sobrepõe ao mero literato.

A possibilidade de se considerar o retratado como João Leão Africano se justifica melhor pela interpretação dos emblemas presentes na tela. Pekka Masonen admite que, apesar de não ser uma unanimidade, existem elementos que sugerem que essa hipótese seja plausível, já que a obra corresponde ao período em que o artista frequentou a corte papal $^{78}$. Em contrapartida ao argumento de que o humanista da tela

\footnotetext{
${ }^{76}$ Ambos os papas originários da influente família florentina dos Medicis: reconhecidos historicamente pelo mecenato e vínculo com atividades mercantis.

77 "Piombo" significa chumbo em italiano. O termo é destinado aos Protetores do selo da Cúria pelo fato de que esse selo também era conhecido como "selo de chumbo".

78 "Modern historians of the popes, for instance, have hardly noticed his presence in Rome at all. Nevertheless, it has recently been suggested that the painting entitled 'Portrait of a Humanist' by the Venetian artist Sebastiano del Piombo (Sebastiano Luciani, c. 1485-1547) might depict Leo Africanus. This painting is dated to c. 1520, when Piombo was working in Rome, and it now belongs to the National Gallery of Art in Washington DC. An alternative identification of the portrait is Marcantonio Flaminio
} 
de Sebastiano del Piombo era o viajante granadino, Natalie Zemon Davis considera essa hipótese pouco provável, pois:

\begin{abstract}
"The book at the scholar's arm is not written in Arabic. The globe, like the map, is a frequent object in a pointing of a scholar in Italy - and this one seems not to be displaying Africa. There are none of the conventional indications found in early sixteenth-century Italian painting that the man has a nonEuropean origin and Muslim origin: no distinctive headdress, no cloak or mustache. There is not even an Ottoman carpet covering the table at the scholar's elbow, a motif introduced earlier by Sebastiano in Italian portraiture; nor are there the accoutrements of an ambassador from the Muslim world ${ }^{79}$."
\end{abstract}

De fato, o que realmente importa nessa discussão não é a revelação da identidade do retratado, mas sim o fato de que é crível supor que o "homem humanista" do século XVI corresponde a João Leão Africano, àquele que sintetiza em si mesmo a concepção pluralista do homem moderno.

A ideia de que se construiu uma imagem moderna da figura de João Leão Africano pode ser reforçada pela própria trajetória de vida do viajante granadino e sua posterior inserção na corte papal de Leão X. Além disso, a importância de João Leão Africano para a formação da modernidade europeia é ressaltada também pelo fato de que ele foi respeitado em todo o continente como uma das fontes mais confiáveis sobre a África até a exploração sistemática das terras africanas pelos europeus. Desse modo, o percurso de vida do viajante granadino pode ser tomado como expressão concreta de um homem moderno voltado para o mundo, transpondo suas fronteiras territoriais e individuais. O relato sobre o "desconhecido" se realiza na própria trajetória do viajante, que depende da ação do imponderável para situar-se em sua época. Este é o século XVI, marcado pelos descobrimentos marítimos e pelos primeiros indícios de que aos poucos o histórico Mar Mediterrâneo foi se estendendo para o incógnito Oceano Atlântico ${ }^{80}$.

De fato, muito pouco se sabe e se pode comprovar sobre a vida de João Leão Africano, mas esse silêncio foi paulatinamente sendo substituído por uma notoriedade de sua figura que circulou por toda a Europa moderna. Autores, como Pekka Masonen, atestam a escassez de informação sobre a vida do citado viajante, mas reforçam que,

(1498-1550), a noted scholar and poet who was a friend of the artist." Pekka Masonen. Leo Africanus: The Man with Many Names. Al-Andaluz-Magreb. 2000/01, v. 1, n. 8-9- p. 125.

${ }^{79}$ Natalie Zemon Davis. Trickster Travels: a Sixteenth-Century Muslim between worlds. New York: Hill and Wang, 2006. p. 302, nota 55.

80 "Entre os séculos XV-XVI e o século XVIII, o desenvolvimento do capital comercial pode ser resumido em termos da formação/expansão de dois grandes circuitos ou complexos de rotas e trocas comerciais: o intra-europeu e o extra-europeu.

O circuito intra-europeu dominou até por volta de 1750 e compreendia quatro complexos regionais: do Mediterrâneo, do Atlântico, Do Báltico, e da Europa Centro-Oriental." Francisco Falcon et Antonio Edmilson Rodrigues. A formação do mundo moderno: a construção do Ocidente dos séculos XIV ao XVIII. Rio de Janeiro: Elsevier, 2006. p. 13. 
apesar da dúvida de que efetivamente João Leão Africano tenha existido, o que se mostra relevante é a própria difusão do personagem como um homem imaginável em pleno século $\mathrm{XVI}^{81}$.

Se por um lado João Leão Africano é um homem moderno devido à sua trajetória como viajante e erudito, pode-se também afirmar que a já citada notoriedade conquistada por ele em toda a Europa do século XVI permitiu que sua condição de "mouro" letrado causasse fascínio no circuito intelectual e artístico do Humanismo renascentista. Em um antigo trabalho de 1922, Lois Whitney ${ }^{82}$ fez a seguinte pergunta: William Shakespeare foi influenciado por Leão Africano? A ideia central do texto de Whitney era discutir a possibilidade de o personagem "Otelo" ter sido inspirado na popularidade do viajante granadino. O famoso "mouro de Veneza", criado por Shakespeare nos primeiros anos do século XVII, continua sendo a representação clássica do ciúme como drama tradicional da experiência humana. A caracterização inicial do personagem coincide com a de Leão Africano: o mouro por excelência que, dotado de certa nobreza, vive em uma corte italiana.

Muitos estudiosos sobre a obra de Shakespeare concentram-se na figura de Otelo como um repósito de contradições, principalmente por representar no mesmo personagem a figura marginal do mouro na Europa cristã, com a grandeza de um general fiel ao Estado e reconhecido por sua bravura. Outros analistas consideram que, independente da sua condição "racial", Otelo é apenas um homem perturbado pela discórdia semeada por Iago, o grande conhecedor dos perigos que o ciúme pode causar à alma. Assim, Otelo não poderia ser definido por sua condição de mouro, já que a origem desse personagem não seria um elemento fundamental para a constituição do seu caráter.

A resposta para essa polêmica não pode ser encontrada diretamente na tragédia shakespeariana, e, certamente, não é uma questão central para a análise da popularidade de João Leão Africano no século XVI. Na construção do personagem Otelo, mais do que sua origem moura, o que o vincula ao viajante granadino são determinadas

\footnotetext{
81 "Very little is known about the actual life of Leo Africanus, in spite of his well-established posthumous fame. He did not leave many marks in contemporary documents. Most information of his life is based on the autobiographical notes in his own work and on the few remarks in other sixteenth-century European texts. Therefore, it has been suggested that the man never existed and that his celebrated description of African geography was actually composed by a Venetian ghostwriter on the basis of contemporary Italian reports on Northern Africa. (...) Leo Africanus is somewhat a legendary character and much of our conventional knowledge of his life rests on speculations made by his enthusiastic admirers." Pekka Masonen. Op cit, pp. 115-116.

${ }^{82}$ Lois Whitney. Did Shakespeare know Leo Africanus? PMLA, Vol. 37, no. 3 (set. 1922)
} 
referências ao seu passado, já que, assim como Leão Africano, Otelo mantinha relações com italianos de origem nobre, viajou por diversos países e popularizou-se pela exposição de uma espécie de psicologia individual ${ }^{83}$. Entretanto, mesmo que seja possível traçar certa paridade entre Otelo e João Leão Africano, é preciso considerar que não existem indícios evidentes de que Shakespeare teve contato com a obra Della descrittione dell Affrica e delle cose notabili che ivi sono; tampouco se pode afirmar que a notoriedade da obra não tenha alcançado o autor inglês e influenciado sua construção de um personagem nobre, valente e mouro, com uma reputação de viajante que, feito cativo, converteu-se ao cristianismo ${ }^{84}$. As trajetórias de João Leão Africano e Otelo são possivelmente coincidentes, mas não apenas porque mito e personagem se combinam em ambos, e sim porque o valente shakespeariano e o viajante granadino são produtos de um contexto cultural que se estende da Europa para a África e da África para a Europa pela mediação dos árabes.

\subsection{O que se molda como barro: a tradução cultural}

O relato de João Leão Africano expressa um intercâmbio cultural entre o Norte da África e a Europa latina mediado pelo "Islã ibérico" do autor. A experiência política da Espanha muçulmana foi, por séculos, uma vivência simbiótica que alimentou uma produção cultural integrada pelos legados históricos de judeus, cristãos e muçulmanos, e que, entre assimilações e conflitos, fez da tradução cultural uma prática particular. A escolha do Papa Leão $\mathrm{X}$ pela mediação cultural de um granadino exilado reafirma $\mathrm{o}$ lugar de al-Andaluz no intercâmbio de ideias entre África, Islã e Cristandade, em um cenário que fez das viagens marítimas o espaço de tradução e significação de conceitos e experiências.

\footnotetext{
83 "We have still to explain not only the simplicity, frankness, and nobility of the character of Othello in spite of his sudden fit of passionate jealousy, but the whole colorful background of Othello's past: his connection with 'men of Royal siege,' his wanderings from country to country that made it possible for Roderigo to describe him as 'an extravagant and wheeling stranger of here and everywhere;' his conversion to Christianity; and his captivity and 'most disastrous chances'." Lois Whitney. Did Shakespeare know Leo Africanus? PMLA, Vol. 37, no. 3 (set. 1922) pp. 473.

84 "More vital than these resemblances in the career of Leo Africanus and Othello is the similarity in traits of character between the Moor, as described by Leo, and Othello. Othello is continually commended for his soldiership. 'The man commands Like a full soldier', says Montano (II, I, 35-6) and even Iago is forced to admit that "Another of his fathom they have none To lead their business (I, i, 142). Over and over again he is given the epithet of brave and valiant. Montano calls him "brave Othello' (II, I, 38), a Senator, 'brave Moor' (I, iii, 48). He is announced at the council chamber as 'the valiant Moor' and the Duke greets him as 'valiant Othello' (I, iii, 47, 48).” Idem ibidem, p. 480.
} 
Por isso, a ideia de tradução na modernidade não pode ser resumida a uma atividade intelectual linguística, pois ela pressupõe um processo que faz da interpretação de culturas uma negociação que transcende os mundos do comércio e da diplomacia, que também são característicos dessa mesma modernidade europeia. Nas palavras de Burke: a tradução “... deve ser considerada menos uma solução definitiva para um problema do que um caótico meio-termo, envolvendo perdas ou renúncias e deixando o caminho aberto para uma renegociação ${ }^{85}$."

Muitos trabalhos historiográficos, ressaltam a ideia de tradução negociada na Idade Moderna a partir das missões religiosas cristãs em territórios coloniais. As adaptações do catecismo católico às culturas africanas, americanas e asiáticas, por exemplo, servem como modelos de descontextualização e recontextualização dos dogmas religiosos do colonizador elaborados para transmitir seus valores culturais aos povos colonizados ${ }^{86}$.

O que se observa a partir da experiência de tradução cultural do século XVI é que essa atividade não se limitou à ação missionária, mas também foi utilizada como um instrumento político-cultural exercido por outros agentes, como os viajantes que não eram especificamente sacerdotes. Se a modernidade europeia apresenta um processo gradual de quebra do monopólio das explicações mágico-religiosas do mundo, pode-se dizer que o relato de viagem de João Leão Africano também é resultado dessa prerrogativa, como se vê em textos de viajantes islâmicos e cristãos que não eram missionários, tais como os de Marco Polo e Ibn Battuta. É claro que o viajante granadino teve o Islã como elemento fundamental de sua formação cultural, mas não se trata de um sacerdote que elabora ajustes dos fundamentos teológicos de sua fé para nativos não integrantes da sua comunidade religiosa.

Dessa forma, no caso de João Leão Africano e sua Della descrittione dell'Africa et delle cose notabli che ivi sono, há uma sutil peculiaridade entre sua tradução de mundos e aquelas elaboradas por profissionais da tradução textual encomendada, como no caso dos membros de academias de tradução modernas: enquanto os "acadêmicos" exerciam uma atividade "profissional" de tradução, adaptando estritamente os interesses de seus impérios à cultura dos não-europeus, outros integrantes da sociedade europeia

\footnotetext{
${ }^{85}$ Peter Burke e R. Po-chia Hsia. A tradução cultural nos primórdios da Europa Moderna. São Paulo: Editora UNESP, 2008. p. 15

${ }^{86}$ Dentre as diversas obras que contemplam a negociação de valores e símbolos religiosos entre missionários cristãos e populações coloniais destaca-se aqui o trabalho de Charles Boxer. A Igreja militante e a expansão ibérica:1440-1770. São Paulo: Companhia das Letras, 2007.
} 
moderna, como devotos cristãos, médicos ${ }^{87}$, historiadores e viajantes, realizavam leituras mais "amadoras" das diferenças culturais do período ${ }^{88}$.

Como João Leão Africano tornou-se viajante pela ação imponderável da sua condição de exilado, não pode ser visto como um "tradutor profissional", já que, mesmo que seu relato de viagem à África tenha sido "encomendado" pelo Papa Leão X, essa obra não apresenta qualquer preocupação exclusiva com as condições técnicas de melhor tradução e transliteração linguísticas dos idiomas africanos. Nem mesmo em outras obras de João Leão Africano, como sua tradução ao árabe das Cartas de São Paulo e seu dicionário árabe-latim-hebraico, pode-se considerar que o "tradutor" exerceu uma atividade estritamente "profissional", pois a formação simbiótica de sua individualidade não se relaciona com uma formação acadêmico-universalista, senão com o desejo do seu senhor em submeter o conhecimento de seu subalterno à grandiosidade cultural de um projeto colonial forjado.

A prova mais contundente desse caráter circunstancial da produção cultural de João Leão Africano e sua submissão aos interesses do Papa Leão X é o fato de que ao voltar a viver na África no fim da vida, o viajante granadino se "reconverte" ao Islã, o que mostra que sua atividade de tradutor de mundos sob a tutela do sumo pontífice foi resultado de uma estratégia de sobrevivência e negociação cultural particular diante da conversão ao cristianismo imposta pelos seus senhores eclesiásticos. Aos olhos de Peter Burke, os exilados como João Leão Africano podem ser classificados como "semiprofissionais", já que eram homens que tiveram sua carreira de mediadores de mundos imposta pelas circunstâncias ${ }^{89}$.

\footnotetext{
${ }^{87}$ Sobre a relação entre narrativas de viagem e saberes médico-terapêuticos ver: Maria Cristina Cortez Wissenbach. Narrativas de viagem, comércio de escravos e saberes médico-terapêuticos entre cirurgiões embarcadiços (séculos XVII - XIX). $8^{\circ}$ Congreso Ibérico de Estudios Africanos: Encounters of Medicine in Africa between the local and the global: historical and contemporary perspectives. Madri, 14 a 16 de junho de 2012; e Cirurgiões do Atlântico Sul - conhecimento médico e terapêutico nos circuitos do tráfico e da escravidão (séculos XVII - XIX). Anais do XVII Encontro Regional de História - O lugar da História. ANPUH/SPUNICAMP. Campinas, 6 a 10 de setembro de 2004.

88 "Outra distinção útil entre tradutores divide os amadores dos profissionais. A vasta maioria dos tradutores se envolvia nessa atividade apenas uma ou duas vezes na vida. Os amadores incluem uma série de governantes ou futuros governantes, entre os quais a rainha Elizabeth, Jaime I, Filipe IV e Filipe V da Espanha e Ludwig, príncipe de Anhalt. Autores devotos com frequência traduziam outros autores devotos (tanto Luis de Granada como o jesuíta Emmanuel Nieremberg, por exemplo, traduziram Thomas Kempis). Médicos traduziam herbários e obras de anatomia (Annibale Briganti, por exemplo, traduziu os herbários de García de Horta e de Monardes para o italiano)...”. Peter Burke e R. Po-chia Hsia. op.cit. p. 18.

89 "Dois grupos semiprofissionais se destacam do resto. O primeiro, previsivelmente, é o dos emigrados, 'anfíbios' incomunmente bem qualificados para sua tarefa e que, com frequência, faziam carreira da mediação entre seus dois países. Esses mediadores europeus, como os intérpretes profissionais da época, não foram estudados de modo tão intenso como seus equivalentes nas Américas, no império português e
} 
A tradução de culturas elaborada por João Leão Africano revela ao historiador a curiosidade de uma dada cultura por outra. Essa atenção proposital expõe de maneira indiscreta interesses, preconceitos e relações de poder que se expressam também no tema escolhido para esse tipo de tradução. Mais do que explicitar verdades observadas na cultura analisada, a tradução de mundos reforça as premissas da cultura do observador, o que, no caso de João Leão Africano, deixa claro a popularidade das viagens na Europa moderna, bem como o papel da razão islâmica e da razão humanista latina em sua maneira de observar o mundo.

Entretanto, a partir das motivações que levaram à elaboração da obra Della descrittione dell'Africa et delle cose notabli che ivi sono e de seu resultado final cabe questionar se, de fato, o que Leão Africano faz é algum tipo de tradução. Para Oumelbanine Zhiri, por exemplo, há limites para considerá-lo um tradutor stricto sensu. Ainda que em alguns momentos Leão Africano assuma a tarefa de traduzir palavras e sentenças, as conjunturas particulares de sua escrita e do contexto que o forçou ao exercício desse ofício estabelecem limites ao enquadramento do viajante granadino à condição de "tradutor". Ao falar de um espaço, de povos e produtos culturalmente distantes do seu público leitor, Leão Africano assume a condição de uma espécie de "tradutor cultural", principalmente por traduzir os testemunhos e invenções de seus pensamentos, forjados em árabe, para uma língua não materna como o italiano vulgar ${ }^{90}$.

Porém, é inegável que pelo menos um aspecto da atividade tradutória formal tenha sobrevivido em Leão Africano: o caráter interativo que a tradução, em suas variadas formas, produz entre culturas e cenários distintos. Nesse sentido, Sabine Gorovitz ressalta a condição ambivalente do tradutor, responsável por tornar inteligível uma situação de passagem entre duas línguas, culturas ou realidades que se encontram em situação dialética ${ }^{91}$. Todas essas características de passagem e ambivalência se

em outras partes. No Império otomano, por exemplo, os intérpretes eram amiúde 'renegados' - em outras palavras, convertidos do cristianismo ao islã, enquanto os intérpretes portugueses na Î́ndia eram amiúde 'cristãos novos', geralmente de origem judaica." Idem, p. 20.

90 "Though his work is not, as we shall see, strictly speaking a translation, it cannot be properly understood without taking into account the challenges of transcribing meanings in another language. The particular circumstances of his writing, its context, offer a striking magnification of the powers and limits of translation - the powers to open new routes for readers to approach what was previously beyond their knowledge or imagination, and the limits reached by a translator as he struggles with his task, with his own ignorance, but also with his own knowledge, too vast to be conveyed in an adequate form." Oumelbanine Zhiri. Leo Africanus and the limits of translation. (IN). Carmine G. di Biase. (Ed.). Travel and Translation in the Early Modern Period. Amsterdã: Rodopi, 2006. p. 175.

91 "A reescritura que o ato pressupõe ganha sentido a partir da visada interativa. A tradução (do grego traductio: passar de um estado para outro) promove, assim, uma condição de interação, podendo ser abordada como situação de passagem: passagem entre línguas, entre culturas e realidades, passagem entre 
adéquam perfeitamente ao contexto de formação de projetos coloniais entre Europa e África no século XVI. A experiência de conquista comercial do mundo promovida especialmente pelas principais instituições econômicas e culturais da modernidade formalizou nesse momento uma espécie de conjuntura histórica tradutória. $\mathrm{O}$ aumento do interesse dos cristãos europeus pelas terras e produtos que estavam além de seus limites territoriais criava espaços e figuras que encarnavam em si a própria condição transitória do ato tradutório, o que fez com que o Mar Mediterrâneo fosse um espaçointérprete de mundos, e Leão Africano fosse um agente-intérprete de culturas.

No caso específico de Leão Africano, a condição migrante de sua experiência como cativo e viajante pode ser encarada como o que Homi Bhabha chamou de fenômeno tradutório. Mais do que a atividade da tradução linguística em si, a ambivalência e transitoriedade de sua característica de migrante constituía um sujeito da diferença cultural que, por sua formação híbrida, transformava o ajuste cultural da sobrevivência em ato tradutório performático ${ }^{92}$.

Se o sujeito forjado pela diferença cultural produz uma tradução cultural que é a própria negociação dessa mesma diferença, essa perspectiva híbrida do sujeito deve aparecer também no texto produzido por esse agente-intérprete de culturas. Por essa razão, a obra Della descrittione dell'Africa et delle cose notabli che ivi sono não deve ser encarada apenas por sua representação exterior, mas, sobretudo, deve ser percebida como um processo produtivo de significados que sustentam “... referências e diferenças em relação a outros discursos ideológica e historicamente construídos ${ }^{93}$ ". Nesse sentido, há uma relação intrínseca entre o discurso do colonizador e o discurso do colonizado (e vice-versa) no interior de um texto produzido sob os auspícios de certa lógica assimétrica de poder entre o escritor e seu senhor. Essa conexão interna entre colonizador e colonizado mostra-se sempre híbrida pelo fato de que se encontra submersa em um conjunto de referências e diferenças constantemente negociadas.

leitores e autores. (...) Nessa dialética, na qual o tradutor lê a obra do outro, em uma língua outra para escrever a sua obra, a sua posição é ambivalente." Sabine Gorovitz. A tradução enquanto situação de passagem. (IN): Cynthia Ann Bell-Santos et ali. (orgs.). Tradução e Cultura. Rio de Janeiro: 7 letras, 2011. p. 13.

92 “O novo da tradução cultural é semelhante ao que Walter Benjamim descreve como a 'estrangeiridade das línguas' - aquele problema de representação inato à própria representação. (...) Com o conceito de 'estrangeiridade', Benjamim se aproxima de uma descrição da performatividade da tradução como encenação da diferença cultural. A argumentação começa com a sugestão de que, embora Brot e pain se refiram ao mesmo objeto, o pão, seus modos de significação discursivos e culturais estão em conflito uns com os outros, lutando para excluir um ao outro.

${ }^{93}$ Lynn Mario T. Menezes de Souza. Hibridismo e tradução cultural em Bhabha. In: Benjamim Abdala Junior (Org.). Margens da cultura: mestiçagem, hibridismo e outras misturas. São Paulo: Boitempo, 2004. p. 113-134. 
O texto, como expressão máxima da tradução cultural, não se separa da vida do escritor e do contexto sócio-histórico vivido pelo mesmo. Se a obra de Leão Africano pode ser vista como um processo produtivo, torna-se preciso encontrar no espaço intersticial entre palavras e conceitos o lugar que esse "autor-tradutor cultural" ocupa na proposta simbiótica do Renascimento em sua época. Para tanto, basta utilizar duas chaves interpretativas próprias do processo produtivo de significação amalgamadas no relato de viagem: a) as referências do contexto assimétrico de poder da lógica colonial católica papal; e b) a "mediação-diferença cultural” construída pelo viajante no processo de negociação de significados.

Com relação aos aspectos do texto que evidenciam a presença das referências do poder colonial papal sobre Leão Africano, a substituição de conceitos religiosos islâmicos por signos católicos é uma prática que garante ao autor a adequação de seu texto ao público-leitor a que esse material se destina. Quando se refere, por exemplo, aos muçulmanos ou à fé islâmica, o viajante granadino afirma:

"Vedesi adunque come ciascuno dei cinque popoli sono stati in travagli e hanno avuto che fare in quelle regioni. Vero è che 'l popolo di Gumera e di Haoara non ebbe mai titolo di dominio, quantunque esso abbia pure signoreggiato in alcune parti particolari, come nelle croniche degli Africani si legge, e il tempo che questo signoreggiò fu dapoi che egli entrò nella setta di Maumetto. ${ }^{94,}$

"È vero che gli Africani di Numidia e di Libia adoravano i pianeti e a quelli sacrificavano; e alcuni degli Africani negri ebbero in venerazion Guighimo, che nella lor lingua significa il Signor del cielo: e questa buona mente ebbero senza essere informati né da profeta né da dottore alcuno. E d'indi a certo tempo furono introdotti nella legge giudaica, nella quale vi stettero molti anni, in fin tanto che alcuni regni de negri si fecero cristiani, e tanto rimasero nella fede di Cristo che si sollevò la setta di Maumetto, 268 di legira. Allora, andati a predicare in quelle parti alcuni discepoli di Maumetto, con le loro persuasioni tirarono gli animi degli Africani a quella legge... ${ }^{95}$

Nessas duas passagens Leão Africano se refere ao Islã como "a seita de Maomé”. A afirmação de que o Islã é uma seita incute uma condição assimétrica entre a religião/fé de Cristo e a "seita de Maomé". A desproporção entre fé e seita agrega certo caráter de legitimidade à fé como verdade e à seita como dissidência menor e ilícita.

\footnotetext{
94 "Vê-se, pois, como cada um dos cinco povos tem estado envoltos em vicissitudes e tarefas por aquelas regiões. A verdade é que o povo de Gumera e de Aoara nunca teve títulos de domínio, embora estes houvessem também senhoreado em alguns lugares, como se lê nas crônicas dos africanos, e o tempo de seus senhorios foi justo o que fez essa gente entrar na seita de Maomé...”.

95 "É verdade que os africanos da Numidia e da Líbia adoravam os planetas oferecendo sacrifícios. Alguns dos negros africanos veneravam a Guighimo, que na língua deles significa "o senhor do céu". Chegaram a esse bom juízo sem serem informados nem por profeta, nem por douto algum. A partir de certo tempo foram introduzidos na lei judaica, que observaram durante longos anos, tanto que muitos reinos de negros fizeram-se cristãos e permaneceram nesta fé de Cristo até que se levantou certa seita de Maomé, no ano de 268 da Hégira. Foram então a pregar em suas terras, discípulos de Maomé e os converteram a essa fé..."
} 
Nesse momento, Leão Africano se veste do papel social que o Papa Leão X lhe atribuiu após o batismo. A necessidade de operar com os valores do colonizador em seu texto é uma evidência de que o scaltrito Leão Africano é mais fiel à sua sobrevivência do que às verdades religiosas concorrentes no Mediterrâneo do século XVI. De fato, como parece plausível a um homem que se encontra em uma situação de fissura cultural, o autor de Della descrittione dell'Africa et delle cose notabli che ivi sono localiza no ato tradutório dos valores de sua época a astúcia que lhe garantiu resistir e enfrentar padrões ideológicos em um universo moderno de hibridização cultural.

A transformação do relato de viagem em ato tradutório de culturas reaparece em outras passagens que adaptam conceitos islâmicos a valores católicos vigentes no século XVI. Ao explicar, por exemplo, as figuras históricas islâmicas dos califas, o viajante granadino afirma:

\begin{abstract}
"Sempre i pontefici maumettani vietarono agli Arabi di passar con le loro famiglie e con i lor padiglioni il Nilo, fino agli anni 400 di legira, nel quale ebbero licenza da un califa scismatico: e ciò per cagione che uno, che amico e vassallo era del detto califa, si ribellò e regnò nella città del Cairaoan e in tutta quasi la Barberia, doppo la morte del quale rimase per qualche tempo il regno nella casa sua.

Percioché, sì come io ho letto nelle istorie africane, nel tempo d'Elcain califa e pontefice di quella casa essi allargarono i loro regni, e crebbe la setta loro intanto che 'l detto califa mandò un suo schiavo e consigliere, il cui nome fu Gehoar di nazion schiava, con grandissimo esercito verso ponente, il quale acquistò tutta la Barberia e la Numidia e procedette per insino alla provincia di Sus, riscotendo i tributi e l'utile dei detti regni. ${ }^{96,}$
\end{abstract}

No texto de Leão Africano a categoria católica de "pontífice" se mescla ao título islâmico de "califa". Ciente de que na Europa cristã o pontífice é uma espécie de máxima autoridade espiritual e política e, identificando essas características também nos califas do Islã sunita, Leão Africano traduz diretamente um signo pelo outro, aproximando conceitualmente figuras tão diversas quanto papas e califas. Talvez Leão Africano entendesse que explicar detalhadamente os elementos próprios da condição de califa mostraria uma intimidade perigosa do autor com o Islã. De qualquer forma, não há como negar que, por qualquer razão implícita, o autor opta pela

\footnotetext{
96 "'Os pontífices maometanos sempre proibiram os árabes de atravessar o Nilo com suas famílias e suas tendas, até que por volta do ano 400 da Hégira, um califa cismático lhes concedeu licença para fazê-lo. Isso porque um amigo e vassalo desse califa rebelou-se; amigo este que passou a reinar na cidade de Cairaoan e em quase toda a Berberia; depois da morte desse amigo o reino permaneceu na mão de sua família por um tempo. Segundo li nas histórias africanas, no tempo de Elcain ${ }^{96}$, califa e pontífice dessa dinastia herética, o poder desse soberano se estendeu tanto que o califa mandou um de seus servos e conselheiros, chamado Geoar, ao Ocidente com um grandíssimo exército que conquistou toda a Berberia, a Numidia e avançou até a província de Sus, recolhendo os tributos e utilidades dos reinos da citada província."
} 
aproximação/hibridização dos termos, negociando o que pode haver de pontífice em um califa, e o que pode haver de califa em um pontífice.

Não obstante, logo na frase seguinte, quando se refere a um personagem específico como Muhammad al-Qaim Bi-Amrillah (Elcain), os termos califa e pontífice se separam em oposição à estratégia de aproximação utilizada anteriormente. Isso pode ser explicado pelo fato de se tratar de uma figura islâmica em particular, cuja aproximação imediata com um papa ou um rei cristão poderia também significar uma ameaça. Assim, ao se tratar de uma acepção genérica, os vocábulos califa e pontífice podem pertencer a uma mesma chave interpretativa e tradutória, mas, quando atribuídos a figuras pontuais de uma tradição cultural alheia e concorrente à do leitor do texto, parece mais prudente reforçar diferenças de significantes. Esse padrão de separação entre califa e pontífice se repete, quando atribuído a um personagem específico do universo cultural islâmico:

\begin{abstract}
"Ora Gehoar, vedendo che 'l califa di Bagaded non faceva contra di lui alcuno apparecchio di battaglia, allora avisò il suo signore come tutte le regioni per lui acquistate gli prestavano obbedienza, e che le cose erano ridotte in pace e ben difese e guardate. Perciò, quando paresse alla sua felicità di trasferirsi con la persona nello Egitto, valerebbe più la presenza di lui allo acquisto di ciò che restava, che centinaia di migliaia di combattenti, e sarebbe cagione che 'l califa di Bagaded lasciando il ponteficato e il regno se ne fuggisse. ${ }^{97}$
\end{abstract}

A figura em questão é o "califa de Bagdá", que Geoar espera ver abandonando seu "pontificado" e seu "reino". A separação entre pontificado e reino confere a cada vocábulo uma atribuição de poder exclusiva: o pontificado como espaço do poder espiritual, e o reino como espaço de poder temporal. Essa diferenciação não desautoriza a aproximação inicial entre "pontífice" e "califa" anteriormente apresentada. O califa de Bagdá ainda é uma autoridade que controla ambos os poderes, assim como o papa no século XVI. A questão é que Leão Africano identifica a separação entre os poderes espiritual e temporal, mas segue conferindo a papas e califas o domínio sobre esses dois espaços de poder, o que permite aproximá-los e separá-los de acordo com a referência de poder invocada pelo ato tradutório.

\footnotetext{
97 "Vendo Geoar que o califa de Bagdá não movimentava nenhum aparelho de batalha contra ele, avisou seu senhor que as regiões conquistadas prestavam-lhe obediência e que tudo havia acabado; estava em paz, bem defendido e protegido; portanto, quando parecesse conveniente a sua Felicidade vir pessoalmente ao Egito, mais valeria a sua presença para o que faltava por fazer; do que centenas de milhares de soldados, e seria de se esperar também que o califa de Bagdá, abandonando seu pontificado e seu reino, fugisse."
} 
Em termos gerais, os códigos católicos de poder e a adequação do texto aos valores do dominador colonial perseguem Leão Africano ao longo de seu relato. Quando se referia aos fiéis muçulmanos ou recorria ao uso de um adjetivo que defina a comunidade religiosa islâmica, o autor utilizava termos distintos:

"Ora voglio che sappiate che i dui primi popoli, cioè Schachim e Hilel, sono Arabi dell'Arabia Diserta discesi dalla origine d'Ismael figliuolo di Abraham, e il terzo popolo, cioè Mahchil, è dell'Arabia Felice e dipende dalla origine di Saba. E appresso i maumettani è tenuto che quegli ismaeliti siano più nobili di questi di Saba. E percioché tra loro s'è guerreggiato lungamente cerca la maggioranza della nobiltà, è avenuto che essi, così da una parte come dall'altra, hanno composti alcuni dialogi in versi ne' quali ciascuno racconta la virtù, i benefici e i buoni costumi del suo popolo. ${ }^{98 ",}$

"Gli Arabi adunque, quando essi vennero per acquistar la Barberia, trovarono i cristiani già padroni e signori di quelle regioni, per che fecero insieme di molte battaglie. In fine piacque a Iddio di dare agli Arabi la vittoria, onde gli arriani si fuggirono, e chi andò in Italia e chi in Ispagna. Ma, doppo la morte di Maumetto cerca dugento anni, quasi tutta la Barberia divenne maumettana. 99 ",

Nesses dois trechos, Leão Africano utilizou os termos "descendentes de Ismael/ismaelitas" e "maometanos" para caracterizar os muçulmanos e escolheu esses caminhos para ajustar-se aos padrões ideológicos e culturais dos cristãos europeus. Edward Said explica o uso do vocábulo "maometanismo" e suas variações na Europa moderna por meio de uma analogia eurocêntrica empregada constantemente pelos cristãos, que entendem que se a fé de Cristo é o cristianismo, a fé de Maomé é o maometanismo ${ }^{100}$.

O mesmo caráter analógico e comprometido intrínseco aos termos que definem o Islã pela centralidade da figura de seu profeta se repetem no uso do termo "ismaelita", aqui definido pela descendência do filho de Abraão, que não é percebido por cristãos e

\footnotetext{
98 “Agora, eu quero que saibas que os dois primeiros povos, Scachim e Ilel, são árabes da Arábia Deserta e descendem de Ismael, filho de Abraão; e que o terceiro povo, os Machil, é da Arábia Feliz e é originário do reino de Sabá. Creem os maometanos que os descendentes de Ismael são mais nobres que os sabeus, razão pela qual eles têm guerreado longamente pela superioridade de nobreza, e compõem-se diálogos em versos, em ambos os lados em que cada um reafirma a virtude, o benefício e os bons costumes de sua gente."

99 "Quando chegaram a conquistar a Berberia, os árabes se encontraram com os cristãos, que eram donos e senhores daquela região, com quem travaram muitas batalhas, querendo Deus, enfim, dar aos árabes a vitória e fazer com que os arianos fugissem para as terras da Itália e da Espanha. Mas depois da morte de Maomé, cerca de duzentos anos depois, quase toda a Berberia tornou-se maometana. É verdade que muitas vezes essas pessoas se rebelaram, e, negando a fé de Maomé, assassinaram seus sacerdotes e governadores, mas os pontífices mandavam exércitos contra esses rebeldes."

100 "Mas o que é ainda mais importante são os vocábulos e imagens limitados que se impuseram em consequência. A recepção do Islã no Ocidente ilustra perfeitamente o caso, e foi admiravelmente estudada por Norman Daniel. Uma das coações aos pensadores cristãos que tentaram entender o Islã era analógica: posto que Cristo é a base da fé cristã, presumia-se - de modo totalmente errôneo - que Maomé era para o Islã o mesmo que Cristo para o cristianismo. Daí o polêmico nome maometanismo dado ao Islã, e o epíteto automático de impostor aplicado a Maomé." Edward Said. Orientalismo: o Oriente como invenção do Ocidente. São Paulo: Cia das Letras, 2001. 3 a. reimpressão. p. 70.
} 
judeus como seu herdeiro legítimo. De acordo com a tradição judaico-cristã, Abraão teve dois filhos, o primeiro com a escrava Agar (Ismael), e o segundo com sua esposa Sara (Isaque). Os muçulmanos são reconhecidos e reconhecem Ismael como um ancestral comum aos árabes e os judeus e cristãos entendem que Isaque é o filho da promessa de Deus, portanto, herdeiro legítimo de Abraão.

É claro que o embate pela legitimidade da herança abraâmica é simbolicamente mais complexo do que a definição aqui apresentada, mas, o que se torna importante na análise dos termos de distinção das comunidades religiosas no século XVI é a necessidade de separar cristãos e muçulmanos como grupos provenientes de signos identitários diferentes, ainda que no interior de uma mesma ancestralidade simbólicoreligiosa. Nesse caso, Leão Africano repete a estratégia discursiva de permear seu texto com os valores e padrões culturais dos cristãos europeus, direcionando o ato tradutório aos signos do dominador.

Ainda em relação às referências da lógica colonial católica papal, Leão Africano negocia seu papel de tradutor de significantes e significados pelo uso do pronome "nós", incluindo-se novamente como cristão. Ao se referir aos desertos do Norte da África localizados entre a Numidia e a Terra dos Negros, o viajante afirma que:

"Questi diserti appresso noi non sono appellati con nome alcuno, quantunque siano divisi in cinque parti e sia ogni parte nominata dal popolo che vi abita e in quella ha il suo vivere, cioè dai Numidi, $i$ quali sono eziandio divisi in cinque parti. Queste sono Zanega, Guanziga, Terga, Lenta e Berdeoa. ${ }^{101,}$

A identificação do Norte da África como uma região "abaixo de nós" mostra que o centro referencial geográfico de Leão Africano é a Europa cristã. Os desertos dessa parte da África, quando sequer são nomeados, encontram-se simbolicamente não apenas "abaixo" em relação ao território, mas também aquém de "nós", pois, em outra passagem sobre os povos que habitam o Norte da África, o viajante complementa: "Costoro infine sono brutti, mal vestiti, asciutti e macilenti per la gran fame, e tali che pare che la maladizione d'Iddio sia ad ogni tempo stata data sopra questa dannata e pessima generazione, senza da quella partirsi mai. ${ }^{102,}$

Os juízos apresentados aqui por Leão Africano tornam evidente seu esforço em, de alguma maneira, traduzir a África e transitar pela lógica colonial cristã do século XVI.

101 "Esses desertos abaixo de nós não receberam nome algum. Entretanto, dividem-se em cinco partes e cada uma é conhecida segundo o nome do povo que a habita e ali faz a sua vida. São númidas, divididos, por sua vez, em cinco partes: Zanaga, Guanziga, Terga, Lemta e Berdeoa."

102 "Esses árabes são brutos, malvestidos, secos e macilentos por grande fome, como se a maldição de Deus tivesse caído desde sempre sobre essa danada e péssima geração sem nunca sair deles." 
Mesmo sabendo que os povos que habitavam essa região não são exclusivamente “árabes”, ele encarnava em sua visão sobre a África parte dos valores da Cristandade em relação aos não cristãos, incluindo-se como integrante do "nós" colonizador.

Esse argumento permanece quando Leão Africano descreve as diferenças entre o calendário lunar utilizado por africanos e muçulmanos, e o calendário solar vigente na Europa cristã:

"I conti e le regole che tengono gli Africani, e ancora tutti i maumettani, per le cose pertinenti alla fede e alla legge loro tutti sono secondo la luna. E hanno l'anno loro di trecentocinquantaquattro giorni, percioché sei mesi fanno di trenta dì e altri sei di ventinove, il che posto insieme aggiugne alla detta somma. Le feste e $i$ digiuni loro vengono in diversi tempi. L'anno adunque arabo e africano è meno del latino undici giorni, e quelli undici giorni fanno tornar l'anno nostro adrieto. ${ }^{103,}$

Não há dúvidas de que o viajante granadino corresponde às expectativas de seu senhor, o Papa Leão X, naquele momento já falecido. Mais do que o controle inconteste das línguas do poder colonial, o italiano vulgar e o latim, ele domina os códigos simbólicos e signos culturais do projeto religioso e comercial a que o papa submete a África e o próprio João Leão Africano.

Entretanto, outro elemento importante do texto Della descrittione dell'Africa et delle cose notabli che ivi sono é o papel de "mediação-diferença cultura" que Leão Africano assume por meio de um processo de negociação de significados. Um exemplo dessa perspectiva é a maneira como determinadas festividades religiosas aparecem no texto:

"Per il che accorgendosi il principe, a certi nostri atti, che noi di ciò eravamo rimasi stupefatti molto e pieni di maraviglia, ci rispose con parole piacevoli, dicendo che eglino erano nati in quegli diserti ne' quali non nasceva grano, perciò si nudrivano di quello che produceva il loro terreno, e che del grano si provedevano ciascun anno per onorare i forestieri che passavano di là; ma che bene era il vero che solevano mangiar del pane $i$ giorni di certe feste solenni, sì come il dì della pasqua e $i$ dì de' sacrifici. ${ }^{104,}$

103 “As considerações e normas dos africanos, e também de todos os maometanos, no que se refere a sua fé e leis, são baseadas na lua ${ }^{103}$, e seu ano é de trezentos e cinquenta e quatro dias, já que possuem seis meses de trinta dias e outros seis de vinte e nove, os quais, juntos, somam essa quantia. As festas e jejuns caem em datas diversas. O ano árabe e o ano africano têm onze dias a menos do que o latino, e esses onze dias fazem com que nosso ano esteja atrasado."

104 "Percebendo o príncipe que aquilo nos assombrava e maravilhava, disse-nos com palavras agradáveis que nenhum deles era nascido naquele deserto que não gerava grãos, por isso se alimentavam dos produtos originários de sua terra natal e buscavam esses grãos todo ano para oferecer em honra aos forasteiros de passagem, ainda que fosse verdade que eles também comiam o pão em dias de festas solenes como a da Páscoa e a do Sacrifício." 
Já para exemplificar a excepcionalidade do consumo de certo tipo de pão entre os homens de determinado grupo nômade de Zanaga, Leão Africano relata que o uso desse alimento era feito, sobretudo, em reuniões religiosas solenes, como a Páscoa cristã e a Id al-Adha muçulmana (s يد الأ ضحى), “a festa do Sacrifício". Sabendo-se que a grande maioria da população do Norte da África já havia se islamizado no século XVI, principalmente os grupos mais distantes do litoral mediterrâneo, torna-se menos crível que os homens de Zanaga teriam feito menção à Páscoa cristã diante de um viajante muçulmano. A presença da Páscoa como exemplo de solenidade religiosa somente pode ser explicada por se tratar de uma intervenção tradutória de Leão Africano, que, para mostrar a seu leitor europeu cristão o caráter especial que a $I d$ al-Adha tem na cultura islâmica, insere a Páscoa como arquétipo referencial que aproxima a ideia de importância e excepcionalidade da festa do Sacrifício muçulmana. Nota-se que em momento algum Leão Africano preocupou-se em explicar ou mesmo descrever os rituais que compõem a Id al-Adha. A presença do significante "Páscoa" à frente do "Sacríficio" já concede o sentido pretendido pelo ato tradutório de aproximação de um marco do calendário religioso cristão a um equivalente muçulmano. Nesse momento, Leão Africano não anula as diferenças culturais entre Cristandade e Islã, mas apenas recorre à tradução simbólica para mediar os padrões e valores de ambos em um espaço culturalmente poroso como a África desse período.

Em outro trecho do texto, ao ver-se diante da necessidade de explicar certo cerimonial islâmico observável entre povos da África, Leão Africano traduz todo o ritual a partir de significantes e significados que fossem completamente contaminados por juízos plausíveis para os europeus cristãos. Ao descrever o costume da ablução islâmica (الدو ضوء) (105), o viajante granadino revela:

\footnotetext{
"Quelli eziandio che abitano nelle città di Africa sono molto divoti nella fede loro, obediscono ai loro dottori e sacerdoti, e hanno gran cura di saper le cose necessarie di essa fede. Vanno continovamente a fare ordinarie orazioni nei tempi, sostenendo un fastidio da non credere, di lavar per cagione delle dette orazioni molte membra, e alle volte lavano tutto il corpo, come ho meco proposto di dire nel libro secondo della fede e legge maumettana ${ }^{106}$."
}

\footnotetext{
105 “A oração é precedida de uma preparação ritual que inclui a ablução (wudu), a purificação física e simbólica do corpo no ato de lavar as mãos, os braços, o rosto, a boca, as orelhas e os pés em água corrente e ter intenção (niya) de adorar a Deus. A maioria dos especialistas religiosos ('ulama) considera a intenção como sendo a condição definidora da validade de todos os atos rituais, tanto a ablução quanto a oração, o que mostra uma concepção do indivíduo como agente moral a partir de seu uso da razão." Paulo Gabriel Hilu da Rocha Pinto. Islã: religião e civilização - uma abordagem antropológica. Aparecida: Santuário, 2010. p. 57.

106 "Os que habitam essas cidades da África são muito devotos na sua fé, obedecendo aos seus sábios e sacerdotes, e tendo grande zelo de saber o que é necessário para essa fé. Efetuam continuamente orações
} 
Aqui, Leão Africano novamente não se preocupa com os detalhes de uma prática ritual performática própria do Islã. Nesse momento do texto, não há, por parte do autor, nenhuma demonstração evidente que ateste sua íntima relação com um dos elementos litúrgicos mais importantes para a comunidade muçulmana de fiéis, já que o caráter performático do processo cultural está contido na tradução, e não na sua intimidade declarada com a prática ritual. A ablução é descrita inclusive como "tediosa", e a responsabilidade de explicar os meandros desse ritual é transferida para outro momento capítulo da obra.

Mesmo que a descrição da ablução esteja atrelada a valores positivos perceptíveis entre os africanos, tais como devoção, obediência e zelo, a importância do ritual é atenuada, e sua explicação é reduzida a uma lavagem corporal penosa. Nesse caso, a aproximação tradutória transforma-se em redução e simplificação da prática revelada. A mediação cultural concentra-se na reafirmação das diferenças e de um sutil estranhamento do autor em relação ao significado traduzido. O tradutor cultural não deixa de ser, em circunstâncias específicas motivadas por algum perigo que possa correr pelo seu oficio, um scaltrito dissimulador de interpretações.

Algumas vezes, a dissimulação como estratégia tradutória manifesta-se de forma velada na obra do viajante. Sobre a produção intelectual dos africanos, Leão Africano afirma:

"E ne' tempi che i scismatici regnarono nell'Africa, cioè quegli che fuggirono dai pontefici di Bagaded, essi comandarono che si devessero abbruciar tutti i libri delle istorie e delle scienze degli Africani, percioché pareva loro che i detti fossero cagione che gli Africani rimanessero nell'antica superbia, e che facessero ribellar e renegar la fede de Maumetto. ${ }^{107,}$

Nessa passagem Leão Africano chama de “cismáticos" os Fatímidas ${ }^{108}$, fundadores de um califado no século X com sede no Egito e que dominou parte considerável do

ao longo do dia, suportando um fastio incrível de lavar muitos membros por causa dessas preces, e às vezes lavam todo o corpo, como eu pretendo explicar no livro segundo, sobre a fé e a lei maometanas."

107 "E no tempo em que os cismáticos reinaram na África, os que fugiram do pontífice de Bagdá mandaram queimar todos os livros de história e ciência dos africanos, porque parecia que esses livros alimentavam a antiga soberba africana, e que favoreciam a rebeldia e a abjuração da fé de Maomé."

108 "Grupo ismailí que, a comienzos del siglo X, en pleno auge qármata en Arabia, extendió la predicación chií por el norte de África mediante un sistema de misioneros o dais, llegando a asentar un califato antiabasí con capital en Cairuán (911) y, a partir de 969, en El Cairo. Fueron los fatimíes los que levantaron El Cairo y desplegaron en la ciudad una brillante actividad cultural a lo largo del siglo XI: la fundación de la Universidad de al-Ázhar, las Rasail Ijwán al-Safá (Epistolas de los Hermanos de la Pureza), compendio enciclopédico de doctrinas filosófico-religiosas, y el trazado urbano son sus 
Norte da África em seu período de máxima expansão. Ele destaca a destruição de parte do legado cultural e científico dos africanos pela prática da queima de livros como manobra para a destruição cultural do povo dominado.

O que torna esse trecho curioso é o fato de que não se pode retirar de Leão Africano a memória da célebre queima de livros promovida pelo Cardeal Francisco Jimenez de Cisneros, em 1499, durante o processo de reconquista de Granada pelos cristãos. Como vítima da expansão cristã sobre a Península Ibérica, Leão Africano é sensível a esse tipo de episódio, tanto que o destaca em sua própria obra. O fato é que a crítica do viajante granadino à prática Fatímida de apagamento da cultura e da ciência dos africanos pode ser entendida como um ardil para censurar esse tipo de dominação cultural, muito utilizada pelos católicos, principalmente em sua terra natal. Ainda que Leão Africano tivesse apenas cinco anos de idade no momento em que ocorreu a queima de livros em Granada, todo o processo de expulsão e trauma próprio do exílio é parte de sua memória migrante, e como tal, reproduziu-se em sua formação cultural antes da conversão forçada ao cristianismo.

A função de mediador cultural assumida por Leão Africano em sua obra sobre a África tem como particularidade, além do caráter conjuntural de seus atos tradutórios, a aproximação do viajante granadino às práticas intelectuais da cultura humanista latina à qual esteve exposto na corte do Papa Leão $X^{109}$. Em dado momento de sua vida e obra Leão Africano se viu imerso em duas correntes de pensamento que precisavam ser hibridizadas: o adágio latino-cristão e o juízo árabe-islâmico.

\subsection{Com os pés na terra da racionalidade europeia-latina: Virtù e Fortuna}

A afirmação de que um homem de letras ou um artista do século XVI, imerso na efervescência cultural da Europa renascentista, tenha sido influenciado por releituras da

realizaciones más perdurables. Tras una progresiva flaqueza debida tanto a disidencias internas oposición popular alentada por los ulemás sunníes; descontento de los suyos por el incumplimiento de las expectativas renovadoras; exigencias cada vez mayores de un heterogéneo ejército mercenario como a la presión exterior - la era fatimí coincide con el apogeo de las cruzadas -, el califato fatimí acabó sucumbiendo al empuje sunní de la mano del ayubí Saladino (1171)" Luz Gómez García. Diccionario de Islam e Islamismo. Madri: Espasa Calpe, 2009. pp. 105-106.

109 "The topics they apparently covered - history, archaeology, religion, grammar and rhetoric - reflect an outlook similar to that of the humanist intellectual culture of which Leo became a part during these years. our sole manuscript of the Descrittione is dated 1526. It is therefore the work of a fairly young man, somewhere in his early thirties." Crofton Black. Leo Africanus's "Descrittione dell'Africa" and its sixteenth-century translations. Journal of the Warburg and Courtauld Institutes. Vol. 65 (2002). pp. 262-263. 
tradição greco-romana é óbvia. Mas, dentre os diversos temas da tradição da Antiguidade Clássica, qual deles seria capaz de relacionar homens tão distintos e emblemáticos dessa época quanto Nicolau Maquiavel, Hans Sebald Beham e, claro, João Leão Africano?

Esse tema prosaico deve obrigatoriamente envolver um amplo conjunto de questões de política, história, arte e literatura de viagens, além de corresponder a uma experiência de vida comum aos três homens acima mencionados: a adversidade do exílio. Em um período de tantos dissabores pessoais e desventuras que levaram esses homens a mudanças repentinas, nenhum tema artístico-filosófico da tradição grecoromana pareceu mais adequado do que o conceito de Fortuna: uma deusa greco-latina em perene mutação.

Quando essas três pessoas apresentam suas próprias definições de Fortuna no século XVI, fica mais fácil entender quem são esses homens, o que move o pensamento humanista do século XVI, e, sobretudo, como o hibridismo e as simbioses conceituais são importantes características do Renascimento.

O primeiro e mais notável dos homens aqui listados que se propõe o desafio de refletir sobre o conceito de Fortuna é o pensador florentino Nicolau Maquiavel. Existe uma extensa bibliografia que discute a ideia de virtù nos escritos maquiavelianos, e no interior dessas reflexões aparecem questões relacionadas à ação da Fortuna. Em obras como Il Príncipe, I Capitoli, dentre outras, Maquiavel debruçava-se sobre as inquietudes próprias do universo político instável de sua época, sem afastar-se da perspectiva intelectual humanista de aproximação com a Antiguidade Clássica, que ganhou força na Península Itálica a partir do século XIV. Quentin Skinner, ao reforçar a recuperação dos valores clássicos na Europa moderna ressalta que “... à medida que se desenvolvia a terrível história da Itália quinhentista, os humanistas do último período sentiram com dor crescente viver numa era em que a virtù e a ragione não tinham mais condições de conter os golpes da fortuna ${ }^{110}$ ".

Mesmo que Maquiavel não tenha vivido para testemunhar os problemas políticos que dissolveram as convicções dos humanistas ao longo do século XVI, motivados principalmente pela ascensão do Império Habsburgo de Carlos $\mathrm{V}$ na Península Itálica, certa porção de pessimismo e desventura pode ser identificada em suas definições de Fortuna. Quando se coloca em confronto a ação humana e o modo de

${ }^{110}$ Quentin Skinner. As Fundações do Pensamento Político Moderno. São Paulo: Cia das Letras, 1996. pp. 206-207. 
agir da Fortuna, as incompatibilidades entre a busca do homem pela estabilidade e a preferência da Fortuna pela inconstância conferem larga vantagem para a segunda ${ }^{111}$.

De todo modo as concepções maquiavelianas de Fortuna sugerem algum grau de conexão entre o homem e os atributos que definem a ação de fatalidade que ela representa. A Fortuna transforma a ordem do mundo tornando claro o seu poder sobre a humanidade por meio de sua dupla condição: o favorecimento e a opressão. Aqueles que ousam adentrar o seu reino ficam vulneráveis a um conjunto de predicados, tais como imprevisibilidade de tempo, impetuosidade, capricho, imoralidade e sedução. Para cada uma dessas qualidades, a Fortuna oferece uma consequência: não se pode prever quando ocorrerá sua mudança, é preciso encarar a violência de suas transformações, não se deve confiar na sua piedade, não há como esperar da Fortuna qualquer medida moral, e jamais subestimar seu poder de atração sobre os homens. Entre seus predicados e consequências, a tabela abaixo ilustra o movimento abrupto da Fortuna para Maquiavel:

Ação da Fortuna sobre os homens:

\begin{tabular}{|l|c|}
\hline \multicolumn{1}{|c|}{ Predicado } & Consequência \\
\hline 1. Imprevisibilidade de tempo & Mudança surpreendente \\
\hline 2. Impetuosidade & Violência das mudanças \\
\hline 3. Capricho & Inconstância e incredibilidade \\
\hline 4. Imoral & Indignidade \\
\hline 5. Sedução & Encantamento sobre os homens \\
\hline
\end{tabular}

É claro que para alguns existem maneiras de se vencer a volubilidade da Fortuna, principalmente por meio do exercício daquilo que Maquiavel aplicou ao universo político e definiu como o mais importante atributo de um homem, qual seja, a virtù, ou melhor, “... a qualidade de flexibilidade moral que se requer de um

\footnotetext{
111 "A maneira como Maquiavel caracteriza a Fortuna, neste poema, é quase sempre negativa; existe certa incompatibilidade entre a forma de ação humana e a da Fortuna. A ação humana tem uma direção constante e busca a estabilidade, a Fortuna é volúvel e inconstante. A incompatibilidade deriva, justamente, da natureza humana e da natureza da Fortuna. A natureza do homem é constante, assim como são o céu, o sol e os elementos. Os homens sempre foram os mesmos, dotados dos mesmos humores e paixões; e cada homem nasce dotado de um determinado engenho e fantasia que permanecem constantes durante toda sua vida. A Fortuna é constantemente inconstante: é de sua natureza ser volúvel e móvel. Essa incompatibilidade provoca a ruína dos que se deixam levar por ela e daqueles que não lhe opõem obstáculos." Patrícia Fontoura Aranovich. Di Fortuna e a Fortuna em Maquiavel.Cadernos de Ética e Filosofia Política. No. 18. São Paulo, $1^{\circ}$. semestre de 2011. pp. 221-222.
} 
príncipe... ${ }^{112 \%}$. Nesse ponto, autores como Newton Bignotto defendem que Maquiavel é o artífice da separação entre moral cristã e política, distanciando a virtù do conjunto de virtudes religiosas e aproximando-se de uma relação mais pagã entre moral e política ${ }^{113}$.

Os antídotos do homem à ação intempestiva e destruidora da Fortuna não se limitam à moral política condicionada pela virtù. Ao discorrer sobre as considerações de Maquiavel referentes a certa liberdade do homem em relação às ações políticas, Felipe Charbel Teixeira ressalta que:

\begin{abstract}
"Maquiavel, embora tenha sido notabilizado pela oposição entre Fortuna e virtù, também via na prudência um paliativo contra os caprichos da deusa: 'a maldade da fortuna', diz ele nas Istorie, 'pode ser vencida com prudência, pondo-se freio à ambição desses homens, anulando-se as ordenações que alimentaram as facções e prendendo aqueles que não estão em conformidade com a verdadeira vida livre e civil'. O prudente, nesse sentido, é mais livre que os outros homens, por conseguir se manter menos vulnerável à Fortuna. ${ }^{114}$,
\end{abstract}

Em termos gerais, ao concentrar seus esforços reflexivos na tentativa de encontrar maneiras de conter a Fortuna, Maquiavel produz diversas formulações sobre essa força sobre-humana que, baseadas em imagens alegóricas variadas, tecem uma ampla definição sobre poderes imponderáveis que afetam a ação política racional. No interior de um conjunto de representações metafóricas da Fortuna como a roda, o azar, o acaso e o céu, Maquiavel se destaca por, em alguns momentos, definir a Fortuna como algo distinto da "Ocasião" - o ensejo do tempo que deve ser agarrado pelos homens - e representa o que de melhor a Fortuna pode conceder aos mortais. Nesse sentido, a ocasião é um momento oportuno concedido raramente pela Fortuna para permitir aos homens certa participação no mundo sem serem meros expectadoras das vontades imponderáveis. A Ocasião é, portanto, algo somente identificado pelos que exercem a virtù, estabelecendo limites para a fatalidade da ação imprevisível da Fortuna $^{115}$.

\footnotetext{
${ }^{112}$ Cezar Arnaut e Leandro Ferreira Bernardo. Virtù e Fortuna no pensamento de Maquiavel. Acta Scientiarum, Maringá, v. 24, n. 1, fev., 2002. p. 101.

113 "Maquiavel havia escapado em parte do dilema ao separar virtude de virtù. Porém, isso o obrigou a definir melhor essa arte da ação e o confrontou à fama de imoral ao sugerir que o bom ator político pode, para alcançar seus objetivos, recorrer a meios diferentes daqueles pregados pela moralidade dominante." Newton Bignotto. As aventuras da virtude: as ideias republicanas na França do século XVIII. São Paulo: Companhia das Letras, 2010. p. 35.

${ }^{114}$ Felipe Charbel Teixeira. Timoneiros: retórica, prudência e história em Maquiavel e Guicciardini. Campinas: Editora UNICAMP, 2010. p. 98.

115 "Ele (Maquiavel) está mais interessado em descobrir se os homens podem de alguma maneira conquistar algum poder sobre ela (Fortuna). Não é uma questão fácil, acrescida pela dificuldade de distinguir claramente a fortuna de outros conceitos como céu(s), ocasião e tempo. (...) Não raro, também, associa e desassocia facilmente a fortuna com a ocasião ou os tempos. Numa frase encontramos 'Os céus, dando-lhes ocasião ou tirando-lhes (...)', e na seguinte: 'aquelas ocasiões que ela (a fortuna) lhes
} 
Essa separação entre Fortuna e Ocasião apresentada em alguns momentos por Maquiavel faz do pensador florentino uma referência nesse debate, mas não uma unanimidade. Ao longo do século XVI houve uma tendência maior em aproximar as imagens da Fortuna e da Ocasião, permitindo que acaso e oportunidade fossem duas dimensões de um mesmo conceito ${ }^{116}$. Um exemplo dessa perspectiva é a representação iconográfica da Fortuna no século XVI, principalmente na obra de Hans Sebald Beham (1500-1550). Em 1541, o citado artista alemão elaborou uma gravura da Fortuna com elementos importantes para a discussão sobre esse tema:

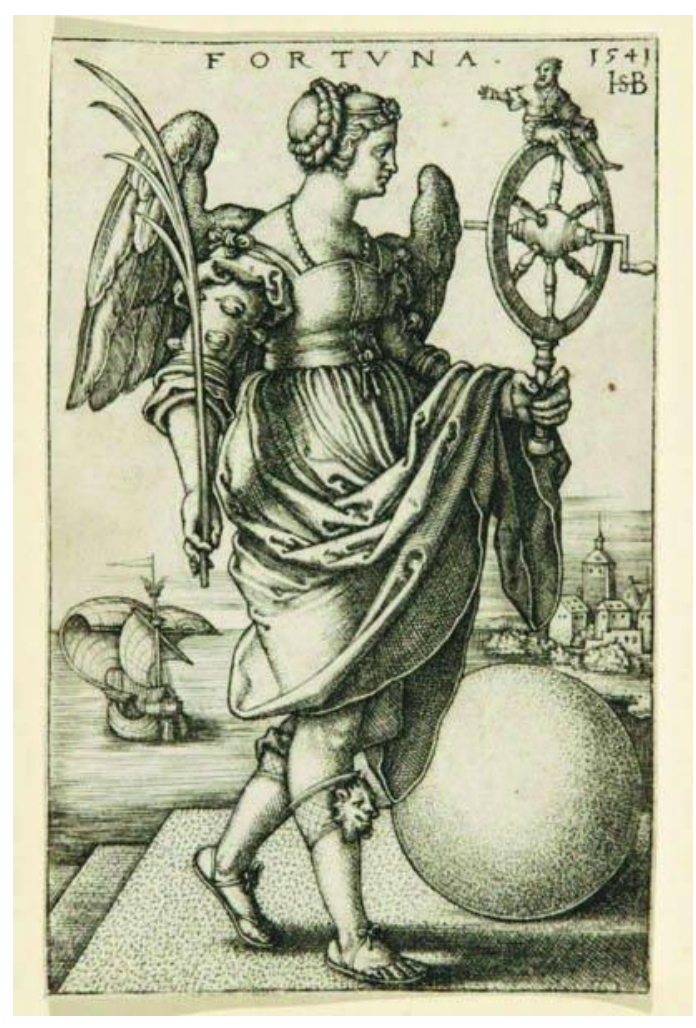

Nessa imagem alegórica existem alguns elementos que merecem destaque porque contribuem diretamente para a discussão sobre os limites do conceito de Fortuna no Renascimento. O primeiro deles é a manutenção da representação feminina para uma força tão poderosa no campo político. A Fortuna é uma imagem de mulher desde a Antiguidade Clássica, mas o que torna esse conceito algo próximo do universo feminino é justamente o reconhecimento de estigmas modernos atribuídos às mulheres,

apresenta." Sebastian de Grazia. Maquiavel no inferno. São Paulo: Companhia das Letras, 1993. pp. 217218.

${ }^{116}$ Sobre a fusão dos conceitos de Fortuna e Ocasião no século XVI, ver: Frederick Kiefer. The conflation of Fortuna and Occasio in Renaissance thought and iconography. The Journal of Medieval and Renaissance Studies 9 (1979). 
tais como inconstância, capricho e sedução. Entretanto, na gravura de Beham, a mulher parece portadora de boas venturas, já que, ao invés de sedutora ou maternal, Fortuna é mais masculina e sóbria, quase soldadesca, envolta em símbolos positivos que suavizam os tais estigmas femininos.

Essa característica fica mais clara ao se analisarem duas importantes figuras postas ao fundo da gravura: o barco e a cidade. Tanto a nau quanto o espaço urbano com seus edifícios bem construídos podem ser entendidos como símbolos diretos de prosperidade. Rubén Soto Rivera, ao analisar as constantes aproximações entre as figuras da Fortuna e da Ocasião no Renascimento e no Barroco destaca que "... hay representaciones tanto de Fortuna como de la Ocasión, de pie sobre una bola o con un manto desplegado en forma de vela, hinchada por el viento. ${ }^{117 "}$ Ainda que essa descrição de Rivera não seja integralmente aplicável à Fortuna de Beham, a bola, o manto estendido e a vela dilatada pelo vento encontram-se presentes em partes distintas da gravura. Por essa razão ao lado da cidade próspera, o barco mostra-se como uma imagem positiva da Fortuna ao adquirir, com a vela inflada, o sentido de controle da inconstância representada pelo vento, um aspecto geralmente atribuído à Ocasião, ou melhor, à felicidade do homem de aproveitar as boas oportunidades que a vida oferece.

O resultado de toda essa construção iconográfica positiva de uma Fortuna/Ocasião pode ser sintetizado naquilo que, na gravura, a mulher segura firmemente: uma roda com um homem montado na sua parte mais alta. Ao contrário de outras metáforas da Fortuna que a vinculam ao "sobe e desce" do movimento cíclico de uma roda, na gravura de Beham a roda encontra-se parada, e, aquele que alcança o seu topo é, sem dúvida, um "afortunado" vitorioso diante das vicissitudes da vida.

A partir dessas metáforas sustentadas pela gravura da Fortuna, Hans Sebald Beham consolida o movimento amplo de aproximação dos conceitos de Fortuna e Ocasião recorrente no Renascimento. Essa justaposição conceitual se revela ainda mais contundente ao se constatar que, ao contrário do que propôs Maquiavel em determinados escritos, Beham não escolhe a imagem da Ocasião para ser uma figura independente da Fortuna, mas elege outro tema como proposta concorrente: Infortunium. Se, por um lado, a Fortuna/Ocasião é especificamente a forma positiva e otimista das ações externas ao engenho humano, Infortunium como antagonista direto é

\footnotetext{
${ }^{117}$ Rubén Soto Rivera. Los pétreos biblionautas del Kairós salmantino. Acceso: Revista Puertorriqueña de Bibliotecología y Documentación. Año/vol. 5, número 001. Sociedad de Bibliotecarios de Puerto Rico. San Juan, Puerto Rico. p. 40.
} 
o símbolo mais persuasivo dos aspectos negativos da ação do imponderável sobre os homens.

Assim como no caso de Maquiavel, a primeira metade do século XVI não foi uma época venturosa para Beham. Acusados de heresia contra o luteranismo e por não reconhecerem a autoridade do Conselho de sua cidade, Nuremberg, Hans Sebald Beham e seu irmão Barthel Beham foram exilados em 1525. Mesmo conquistando o perdão da cidade algum tempo depois, Hans Sebald Beham voltou a ser proscrito de Nuremberg em 1528, dessa vez acusado de ter plagiado o conterrâneo Albrecht Dürer em um escrito artístico.

As vicissitudes políticas de uma vida conturbada podem ter influenciado Hans Sebald Beham a considerar uma contraposição da Fortuna diretamente em relação a Infortunium, e não à Ocasião, como em Maquiavel. Ao representar esse antagonismo conceitual em sua arte, Beham elaborou, em complementaridade à Fortuna, outra gravura destinada a Infortunium:

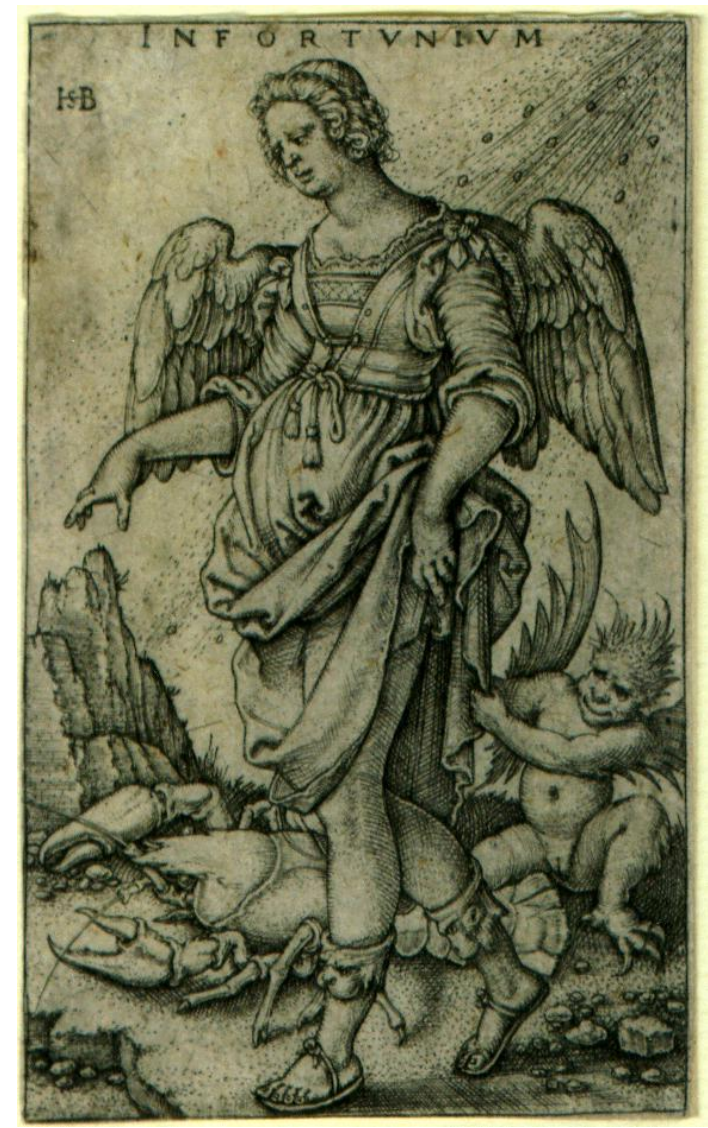

Se Fortuna era uma imagem totalmente positiva da ação do imponderável sobre a vida humana, Infortunium apresentava os aspectos negativos dessa mesma força 
imprevisível. O que marca a aproximação entre as duas figuras é, dentre vários símbolos, o fato de que ambas são mulheres aladas, quase como irmãs contrárias. As diferenças começam a ser apresentadas justamente a partir das sutis semelhanças, reforçando a posição antagônica entre elas. As asas da Fortuna são visivelmente mais altivas, como a própria postura corporal da figura, enquanto que, na imagem do Infortunium, as asas encontram-se ligeiramente caídas, abatidas. Os olhos das figuras também estão dispostos em condições opostas. Fortuna reforça seu brio ao direcionar seus olhos para o horizonte, e Infortunium, em oposição, olha para baixo, lamentosa e melancólica.

Ao invés da próspera cidade, Infortunium tem ao fundo um cenário de ruína que não se vincula ao movimento dinâmico do espaço urbano, mas sim, uma montanha desgastada que recebe o toque de suas mãos portadoras de desgraça. Além disso, a imagem traz um pequeno demônio que carrega em si um aspecto monstruoso e deixa à mostra o órgão sexual feminino. Não há dúvidas de que, para Beham, a desgraça é também feminina, porém, ao invés de soldadesca, ela se compõe como grotesca e assombrosa. Por fim, em sua companhia, Infortunium traz o caranguejo: um animal que por jamais mover-se para a frente representa o contrário da prosperidade, ou seja, o fracasso e a decadência.

Da Florença de Maquiavel para a Nuremberg de Beham, a multiplicidade do conceito de Fortuna percorre um longo caminho que coloca novamente a África na rota cultural do Renascimento. Em diversas circunstâncias de sua descrição sobre os aspectos gerais do continente africano, Leão Africano se refere à presença da Fortuna nas aventuras vividas por ele. O primeiro momento em que essa questão aparece no texto, ela faz menção ao surgimento da cidade de Marrakesh, chamada por Leão Africano de "cidade do Marrocos":

"E d'indi a poco tempo i medesimi Zeneti furono similmente scacciati da alcuni che vennero dal diserto di Numidia, e questi furono d'una prole di Zanhagi, detta Luntuna. Essi ruinorono tutta la regione di Temesna e distrussero ogni spezie di popolo che in quella si trovava, eccetto quelli che erano della origine loro, i quali posero ad abitare in Duccala. Questa cotal famiglia edificò la città di Marocco. Avvenne poi, secondo le mutazioni della fortuna, che un grande uomo nelle cose della lor fede e predicatore appresso loro molto estimato, chiamato Elmahdi, si ribellò e fatto certo trattato con gli Hargia, che furono della stirpe di Musmoda, scacciò questa famiglia di Luntuna e fecevisi signore. ${ }^{118,}$

118 “E, pouco tempo depois, os novos Zenetes também foram expulsos por alguns procedentes do deserto da Numidia. Estes eram de uma prole dos "Zanigi" chamada Luntuna. Arruinaram toda a região de Temesna, e destruíram todos os povos que ali moravam, exceto aqueles de sua mesma origem, e os puseram a viver em Duccala. Essa tal família edificou a cidade de Marrocos e então aconteceram 
Nessa ocorrência inicial, a ideia de Fortuna é formada por duas características presentes também nas considerações de Maquiavel e Beham: a impetuosidade e a imprevisibilidade. Ao ser acompanhada da palavra "mutações", a Fortuna passa a ser entendida como uma força dinâmica arrebatadora. A sua presença abre espaço para o surgimento de situações e personagens extraordinários, como o "Mahdi", uma figura religiosa envolta em mistério e recorrente na escatologia islâmica. Do ponto de vista simbólico, o "Mahdi" está vinculado ao destino final da humanidade, e, por isso, a presença da Fortuna nessa parte do texto reforça todas as características sobre-humanas que o conceito de Fortuna pode adquirir.

Em outro trecho do texto, quando trata de uma decisão equivocada tomada por um califa imprudente, Leão Africano invoca o simbolismo do termo Fortuna para exemplificar as consequências da ação política e militar descuidada:

“Come questa bella e magnanima esortazione pervenne all'orecchie del signore, esso, senza altrimente considerare a quello che potrebbe avenire in contrario, insuperbito dalle lusinghe della seconda fortuna preparò un grosso esercito e partissi, lasciando per governatore e general capitano di tutta la Barberia un principe del popolo di Zanhagia, il quale gli era non pure amico, ma domestico servitore. ${ }^{119,}$

Nessa passagem, de acordo com a versão original, o substantivo "fortuna" é precedido da palavra "seconda", o que, se traduzido literalmente, não conferiria sentido à frase. Dessa forma, pode se tratar de um engano paleográfico de leitura da escrita original, já que, de acordo com o cotejo feito com outras traduções, para o espanhol ${ }^{120} \mathrm{e}$ o francês ${ }^{121}$, opta-se por termos como "fecunda" e "par le beau semblant que fortune luy faisoit". Uma saída possível para esse problema é considerar "seconda" como particípio do verbo "secundar", no sentido de "criar condições para (surgimento ou

mutações da fortuna que fizeram com que um grande homem nas coisas de sua fé e predicador muito apreciado, chamado de "Elmadi", se rebelasse e, firmando um acordo com os "Argia", que eram da estirpe de Musmoda, derrubasse a família de Luntuna e se fizesse senhor."

119 “Com essa bela e magnânima exortação chegada aos ouvidos do senhor, este, sem pensar muito e sem considerar o que podia contrariamente acontecer, senão envaidecido pela adulação da favorável fortuna, preparou um grande exército e partiu, deixando como governador e general capitão de toda a Berberia, um príncipe do povo de Zanagia, o qual não era somente amigo, mas também servidor de sua casa."

${ }^{120}$ Serafín Fanjul (trad.). Descripción General del África y de las Cosas Peregrinas que allí hay. Granada: Fundación El Legado Andalusí. 2004. p. 100.

${ }^{121}$ Jean Temporal. (trad.). Historiale Description de l'Afrique, tierce partie du monde. Lion, 1556. http://gallica.bnf.fr/ark:/12148/bpt6k1044206/f3.image.r=description\%20afrique.langFR 
ocorrência de algo); propiciar, favorecer. ${ }^{122 \%}$. De todo modo, o significado que Leão Africano confere ao termo Fortuna aqui está vinculado à noção de "capricho", já que o abandono premeditado dos seus domínios pelo califa foi causado pela bajulação que a Fortuna destinou ao mesmo. Ardilosamente, a Fortuna engana os fracos e muda de forma abrupta os planos dos homens.

Ainda em relação ao mesmo califa, outra referência à Fortuna é feita quando um de seus funcionários mais próximos tenta consolá-lo:

"Signore, i mutamenti della fortuna sono varii, né perciò vi dovete voi diffidar della vostra virtù per lo nuovo accidente da lei avenuto: percioché, quando voi vorrete accostarvi a quello che io, che fedelissimo vi sono, bene e lealmente saprò consigliarvi, io non dubito che non riabbiate in brevissimo tempo tutto quello che per ribellione è stato da voi alienato, e appresso non otteniate l'intento vostro. Il che farete senza pagar soldato niuno, anzi io voglio che più tosto lo esercito che vi porrò nelle mani paghi voi, per le cagioni che io vi dirò ${ }^{123}$,"

A mensagem de consolação enviada ao califa por um funcionário tenta convencêlo de que a inconstância da Fortuna, responsável pelo revés político, pode novamente flertar com as ambições do califa. Trata-se de uma manobra do funcionário para convencer o califa a autorizar os planos militares do próprio funcionário, manipulando a imagem instável da Fortuna. Ao mesmo tempo em que o caráter volúvel da Fortuna é reforçado, o trecho sugere a fusão entre os conceitos de Fortuna e Ocasião, como visto também na gravura de Beham. Se o funcionário apresenta uma nova situação para reverter o prejuízo causado em um primeiro momento, ele alude à chegada de uma nova oportunidade em que a Fortuna pode reaproximar-se do califa, pois sua queda temporária não foi fruto de qualquer degeneração de suas virtudes, mas apenas das circunstâncias desfavoráveis. Pode tratar-se apenas de uma adulação do funcionário em relação ao califa? Possivelmente; porém, o sentido de que a instabilidade da Fortuna oferece uma nova oportunidade e tempo para a concretização do projeto ambicioso do califa segue fortalecendo a união entre os conceitos de Fortuna e Ocasião.

A recorrência de sentidos para o conceito de Fortuna permeia as principais descrições de Leão Africano. Quando expõe os perigos das travessias caravaneiras entre a Mauritânia e a Numidia, o viajante granadino apresenta uma nova leitura do termo:

\footnotetext{
${ }^{122}$ Essa acepção do termo "secundar" foi extraída do Dicionário Eletrônico Houaiss da Língua Portuguesa.

123 “Senhor, a fortuna é extremamente mutável; não tens que duvidar de vossa virtude pelo incidente ocorrido. Se dás importância ao que esse fidelíssimo servo quer infundir-te bem e lealmente, não duvido de que recuperarás em breve tudo o que por rebeldia foi-te alienado e obterás tão logo desejes. Não deves contratar soldado algum: mas, o exército que colocarei em suas mãos é o que deverás recompensar, pelas razões que direi."
} 
“... né solamente la carovana, ma tutti gli alberi sono coperti, di modo che non si può vedere orma né segno dove siano i corpi morti. E io due fiate per gran miracolo sono scampato dal pericolo di questa morte nel tempo che io facevo questi cammini, delle quali non vi dispiacerà intender come una me ne avenisse. ${ }^{124,}$

Diante do perigo das tempestades de neve enfrentadas, a morte parece ser contida pela interferência da Fortuna na vida de Leão Africano. O detalhe que chama a atenção nessa passagem é o fato de que, ao invés do crédito da boa sorte ser atribuído à ação da Fortuna, trata-se, ainda que metaforicamente, de um "milagre". A substituição dos significantes é importante porque indica uma alteração nas atribuições da ação das forças imponderáveis. Leão Africano, assim como outros autores do século XVI, vincula suas representações simbólicas ao pensamento cristão vigente. Por essa razão, a deusa pagã Fortuna deve dividir seu espaço de atuação com outro conceito cristianizado: a ideia de Divina Providencia (Providentia).

Não cabe aqui discutir a polissemia do termo Providentia na tradição cultural europeia, mas, ao se tomar o texto de Leão Africano, vê-se que os predicados atribuídos à Fortuna/Ocasião, e até mesmo a Infortunium, em alguns momentos de sua obra são relacionados à vontade de Deus:

\footnotetext{
"Ora, seguendo il cammino sempre al buio e per gl'incommodi sì del tempo come della notte, quando piacque a Dio sentimmo il belar di molte pecore, verso il quale ci inviammo drizzando i cavalli tra boschi e alte rupi, di maniera che ci soprastava un altro pericolo. ${ }^{125}$,"
}

"A me levarono il cavallo e mi accomandarono a Dio. Io, preso a vettura un mulo fornito con certe bardelle che usano coloro tra quei monti, il terzo dì giunsi a Fez, dove trovai che già era stata recata la trista novella, e io similmente da' miei era stato riputato morto come gli altri. Ma ciò per sua bontà non era piaciuto a Dio. ${ }^{126,}$

\footnotetext{
124 “Não somente a caravana, mas todas as árvores ficam cobertas, de modo que não se pode ver pegada nem sinal de onde estão os corpos mortos, e eu duas vezes escapei dessa morte por milagre no tempo em que eu percorria aqueles caminhos. Acredito que vocês não se importariam de entender como ocorreu em uma dessas vezes."

125 “Agora, seguindo o caminho sempre no escuro, e tão incômodo pelo mau tempo como pela noite, quis Deus que escutássemos o balido de muitas ovelhas, e ali conduzimos os cavalos entre bosques e altos penhascos, de maneira que sobressaltava um perigo maior."

126 "A mim, levaram-me o cavalo, e me deixaram ao acaso (accomandarono a Dio). Eu fiz uso de uma mula com certo tipo de sela que usa a gente desses montes e no terceiro dia de jornada acerquei-me de Fez, onde achei que já havia chegado a triste notícia e o conhecimento de minha morte, o que não quis a bondade de Deus."
} 
Em ambas as passagens, as circunstâncias da vida de Leão Africano são definidas pelos desígnios de Deus. A ação da Providentia como Fortuna é tanto a expressão direta da vontade Dele (como no primeiro caso) e metáfora para a própria ideia de casualidade (como no segundo trecho). Não obstante, ao se traduzir a expressão italiana "accomandarono a Dio", deve-se levar em consideração o fato de que a passagem sugere o sentido de que Leão Africano foi deixado à sua "própria sorte", ou, em uma expressão que mantém o sentido de "vontade de Deus", "ao deus-dará". Para conferir melhor significado à passagem, a ideia de "me deixaram ao acaso" parece se encaixar mais adequadamente no desígnio do autor e reforça o argumento de que a Providentia cristã se funde à Fortuna pagã latina. Ao final, Leão Africano é salvo da morte pela ação do imponderável, e, a partir dessa experiência, reconhece que, ao longo de sua narrativa sobre a África, sua vida foi constantemente preservada por forças misteriosas, já que seu fim foi um risco que “... não quis a bondade de Deus” (Ma ciò per sua bontà non era piaciuto a Dio).

\subsection{A terra da vergonha: a racionalidade árabe-islâmica entre a vergonha e a honra}

Se por um lado Leão Africano negocia os valores e símbolos de sua tradução cultural da África a partir da tradição latina-cristã relida pela experiência do Renascimento, seu texto também é permeado por contribuições significativas de certos elementos da tradição árabe-islâmica. Uma das questões mais importantes que envolvem esse aspecto cultural é a forma como o autor avalia moralmente os africanos, pois as categorias de classificação moral desses povos estão vinculadas a critérios sociais valorizados tanto pela cultura árabe-islâmica, quanto por um modo de vida que ficou conhecido na antropologia cultural como "sociedades mediterrâneas". Autores como J. G. Peristiany ${ }^{127}$, Julian Pitt-Rivers ${ }^{128}$, John Davis ${ }^{129}$, Jeremy Boissevain ${ }^{130}$, e, principalmente, David Gilmore ${ }^{131}$, contribuíram para a formação de uma área de estudos

\footnotetext{
${ }^{127}$ J. G. Peristiany. (org.). Honra e Vergonha: valores das sociedades mediterrâneas. Lisboa: Fundação Calouste Gulbenkian, 1971.

${ }^{128}$ J. A. Pitt-Rivers. Un pueblo de la Sierra. Madri: Alianza Editorial, 1989.

129 John Davis. People of the Mediterranean: An Essay in Comparative Social Anthropology. Londres: Routledge, 1977.

${ }^{130}$ Jeremy Boissevain. Towards a Social Anthropology of the Mediterranean. Current Anthropology, Vol. 20. No. 1, 1979.

${ }^{131}$ David D. Gilmore. Anthropology of the Mediterranean Area. Annual Review of Anthropology. Volume 11, 1982.
} 
"mediterrâneos" que abrange regiões e povos distintos com valores sociais aproximados.

Por mais que a criação teórica de uma grande área de estudos do Mediterrâneo tenha certa vocação ao eurocentrismo e alguns pontos questionáveis, as análises sobre os sistemas de valores de algumas dessas sociedades podem ser oportunas para o entendimento da tradição árabe-islâmica em Leão Africano, principalmente por meio de dois conceitos tributários dessa antropologia cultural: a honra e a vergonha.

A primeira característica relevante do binômio honra/vergonha é a distinção da aplicação desse conceito para homens e mulheres ${ }^{132}$. Assim como nas questões de honra, com o campo masculino sendo definido por temas como a virilidade, e a mulher pela fecundidade, essa distinção de gênero também aparece nas questões relativas à vergonha, com os homens sendo alvo de injúrias e, as mulheres, de obscenidades. Esse padrão binomial honra/vergonha, homem/mulher, virilidade/fecundidade e injúria/obscenidade possui ressonância na organização simbólica de uma dada região, que aqui não será o Mediterrâneo clássico da antropologia cultural, que estabelece o fluxo cultural da Europa para a África, mas sim o contrário.

Ao se tomar a honra masculina como ponto de partida para a discussão sobre a tradição árabe-islâmica em Leão Africano, vê-se que um elemento de destaque da cultura árabe, especificamente magrebina, é o uso de uma linguagem obscena estruturadora das relações de honra e vergonha, em especial referindo-se a órgãos sexuais, relações familiares e sexualidade ${ }^{133}$. Por isso, a capacidade viril do homem é uma questão que regula o tênue limite entre a honra e a vergonha, já que, se for atribuída a uma figura ou a um povo, passa a conferir status de honradez, e, se for negada, transforma-se em insulto.

\footnotetext{
132 "While certain virtues such as honesty, integrity, loyalty and other moral qualities are common to both sexes (Pitt-Rivers 1977:22), the concept of honour and shame has largely to do with a person's gender and consequently his or her position in society and the household (Malina \& Neyrey 1991a:41). 'The honour of a man and of a woman ... imply quite different modes of conduct' (Pitt-Rivers 1977:20)." Renata Rabichev. The Mediterranean concepts of honour and shame as seen in the depiction of the biblical women. Religion and Theology. Vol 3/1. 1996. http://www.unisa.ac.za/default.asp?Cmd=ViewContent\&ContentID=7356

133 "Todas las formas idiomáticas del lenguaje obsceno magrebí se refieren a los órganos genitales, a las relaciones de parentesco y, en general, a lo sexual. Por consiguiente, resulta abusivo, o incluso escandaloso ('ar, aib) hacer chistes verdes alusivos a este tema general. Sólo el amor oblativo de una madre por su hijo es cantado abiertamente. Por eso la lengua ha inventado una serie de locuciones idiomáticas y eufemismos que permiten mantener el decoro cuando se produce una situación desagradable." Malek Chebel. El espíritu de serrallo: estructuras y variaciones de la sexualidad magrebí. Barcelona: Bellaterra, 2000. pp. 64-65.
} 
Malek Chebel ressalta a importância de um vocabulário magrebino voltado às questões de virilidade, mesclado a expressões idiomáticas que apontam para firmeza de caráter e temperamento forte. Ao termo virilidade, do árabe clássico, muruwwa (المروءة), o Magreb recorre à expressão rayel u nesf (وذ صف الدرجال), literalmente "homem e meio".

As maneiras como a virilidade se manifesta são variadas, mas geralmente encontram-se submetidas ao desejo sexual masculino. Ao descrever as características e o tempo de vida dos nativos da Terra dos Negros, Leão Africano reafirma essa premissa, ao alegar:

“... ma pur si trovano ne' monti della Barberia uomini che forniscono cento anni e alcuni che ve gli passano. E sono questi d'una gagliarda e forte vecchiezza, percioché ho veduto io vecchi d'ottanta e più anni arar la terra e zappar le vigne, e far con destrezza mirabile tutti gli altri lavori che vi bisognano; $e$ quel ch'è più, ho veduto nel monte Atlante uomini di ottant'anni entrare in battaglia e combatter valorosamente con giovani, e molti di loro rimaner vincitori. (...)

Nella terra negra sono le vite molto più corte di quelle dell'altre generazioni, ma gli uomini stanno sempre robusti e $i$ lor denti sono sempre fermi e a un modo: ma sono uomini di gran lussuria, sì come anco quegli di Libia e di Numidia; e quei di Barberia sono generalmente di minor forza. ${ }^{135,}$

O elemento de distinção social entre os nativos da Terra dos Negros e da Berberia é justamente a virilidade. Ao se referir à menor lascívia dos berberes, Leão Africano utiliza o vocábulo "forza", em conexão direta com um signo metafórico expressivo da virilidade masculina: a força física. Ainda que os atributos guerreiros dos que habitam as montanhas da Berberia sejam exaltados, não chegam a ter sua honra masculina questionada, mas precisam de um número maior de atributos para serem descritos dignamente no texto, tais como, galhardia, destreza, valentia e "velhice forte", o que retira a carga metafórica sexual da qualidade de força corporal atribuída aos nativos da Terra dos Negros.

Entretanto, certos estigmas sociais são capazes de retirar a credibilidade moral de um povo, o que atinge diretamente os signos de virilidade conferidos ao mesmo.

\footnotetext{
134 "El equivalente de la noción de rayel u nesf en la tradición árabe clásica es la muruwwa, que significa 'virilidad', 'carácter', 'personalidad aguerrida' o 'dominio de si mismo'. Esta noción corresponde a uno de los valores cruciales de la ética árabe, ya que engloba casi todos los criterios del modo de ser beduino. Idem, pg. 67.

135 "Mas encontram-se nos montes da Berberia homens que chegam a cem anos e alguns que superam essa idade. Estes possuem uma velhice galharda e forte, pois eu vi velhos de oitenta e tantos anos arando a terra, cavando as vinhas e realizando com destreza admirável todos os outros trabalhos que se faziam necessários e, mais ainda, eu vi no monte Atlas homens de oitenta anos irem à batalha, combatendo com valentia ao lado de jovens, e muitos deles permaneceram vitoriosos.

$\mathrm{Na}$ terra dos Negros, são as vidas muito mais curtas do que entre outras regiões, mas seus homens estão sempre robustos e seus dentes são sempre firmes. São homens de grande luxúria, assim como os da Líbia e da Numidia. Os homens da Berberia são geralmente menos lascivos (di minor forza)."
} 
Com relação aos líbios, esses sinais identitários depreciativos e de grande carga de julgamento moral são expressivos:

\begin{abstract}
"Quegli di Libia sono bestiali, ignoranti, senza lettere di niuna sorte, ladri e assassini, e vivono come fanno gli animali salvatichi. Sono eziandio senza fede e senza regola, e vissero in ogni tempo, e vivono, $e$ sempre in miseria viveranno. Non è sì grande e orribile tradimento, che essi per cagione e desiderio di robba non facessero; né sono animali che più portino lunghe le corna di quello che se le porta questa canaglia. Tutto il tempo della vita loro consumano o in far male o in cacciare o in far tra lor guerra o in pascer le bestie per li diserti, e sempre vanno scalzi e nudi. ${ }^{136,}$
\end{abstract}

Nessa referência aos habitantes da Líbia, Leão Africano não poupa suas palavras. Eles são enquadrados em um conjunto de valores tão desonrosos que passam a ter a sua condição humana questionada. Alguns elementos da descrição moral desses povos os colocam sob uma categoria distante daquela reconhecida em uma sociedade islâmica padrão. Não possuem fé, regras, e, por conseguinte, vivem em uma situação de miséria justificada pela degeneração de princípios e virtudes consideradas sagradas não apenas pelo Islã, mas também por qualquer sociedade cristã que entrará em contato com esse texto.

Contudo, dentre todos os indícios morais da fraqueza e falta de honradez dos líbios, aquele que mais os caracteriza como moralmente inferiores é a falta de controle sobre os impulsos sexuais de suas mulheres. A condição de "cornos" faz com que sejam mais identificados pela naturalidade com que encaram o adultério do que com qualquer outro princípio de questionamento da virilidade de seus homens. Nesse sentido, a quebra da sacralidade do matrimônio, e, principalmente, da aliança sexual entre maridos e esposas, reflete o modo descuidado com que esses povos zelam pelo casamento como única situação social de pleno exercício da sexualidade humana ${ }^{137}$.

Com a denúncia da falta de controle da atividade sexual de suas mulheres, Leão Africano aponta o segundo elemento estruturante da aplicação do binômio honra/vergonha à sua leitura moral dos homens africanos: a falta de controle sobre a família, e, mais especificamente, sobre a defesa da honra dos seus membros femininos.

\footnotetext{
136 “Os da Líbia são bestiais, ignorantes, sem letras de nenhuma sorte, ladrões e assassinos; e vivem como os animais selvagens. São também sem fé e sem regra, vivendo a todo o momento na miséria. Não há traição, por maior e mais horrível que seja, que não cometam por ganância, tampouco existem animais que carreguem chifres maiores que os que sustentam essa canalha. Por toda a vida são dados a caçar, fazer mal, ou ir à guerra, e levar seus animais para pastar nos desertos; sempre descalços e desnudos."

137 "Por meio do eixo da sexualidade é que toda a existência humana é verdadeiramente considerada. Daí essa ampliação, essa inflação da sexualidade. A sexualidade deve ser levada a sério, pois testemunha o que há de sério na existência. Toda vida, de acordo com os ensinamentos islâmicos, banha-se num ambiente sexual. Isso por vezes chega às raias da obsessão. É necessário casar-se. É necessário copular." Abdelwahab Bouhdida. A sexualidade no Islã. São Paulo: Globo, 2006. p. 125.
} 
Renata Rabichev ressalta essa questão nas sociedades mediterrâneas ao reforçar o sentimento corrente nessas comunidades de que a traição sexual da esposa é a prova social definitiva de que um homem falhou em sua obrigação de zelar pelo pudor das mulheres sob sua tutela, e, com isso, torna-se socialmente menos honroso, confiável e viril $^{138}$.

No interior dessa lógica punitiva em relação ao patrimônio familiar, constrói-se a honra feminina baseada na ideia de fertilidade. A virgindade da jovem que se prepara para o casamento é, do ponto de vista simbólico, o primeiro grau do sistema de conduta moral a considerar a mulher apta ao acesso lícito à sexualidade e à procriação.

Tanto o Islã quanto o Cristianismo edificam parte de seu ethos religioso a partir da defesa da castidade, principalmente em relação às mulheres solteiras. O Cristianismo, e, mais pontualmente, o Catolicismo, como conjunto de dogmas ordenadores da comunidade de fieis, têm um episódio de virgindade como o milagre inicial de fundação de sua experiência religiosa excepcional com a condição imaculada da concepção de Maria. A escatologia islâmica, e mesmo a tradição cultural pré-islâmica da Península Arábica, também conferem status privilegiado à virgindade em seus códigos de representações morais. No Magreb, e em outras sociedades mediterrâneas, a construção social de um modelo paradigmático de esposa transforma a virgindade em signo primordial da honra feminina, assim como a "não-virgindade" é um critério de estabelecimento da vergonha social que não se limita à mulher, mas se estende também, como visto, aos integrantes masculinos da sua família.

Certamente, a partir de negociações contínuas com todos esses conjuntos de dogmas e tradições que valorizam a virgindade como critério de honradez feminina, Leão Africano direciona seu julgamento moral aos povos da África que descreveu. Sobre a vida dos pastores das montanhas da Berberia, ele afirma:

\footnotetext{
"I pastori, così dei monti come delle campagne, vivono amaramente delle fatiche delle lor mani e stanno in continova miseria e necessità. Sono bestiali, ladri, ignoranti, né pagano mai cosa che lor si dia a credenza. E di costoro sono in maggior numero i cornuti che d'altra sorte. A tutte le giovani, prima che si

138 "A man of honour should possess integrity, nobility of spirit, he must be competent with regard to various problems and dangers, and know how to solve them (Campbell 1964:213, 269--270). He is associated with esteem, refusal to submit to humiliation, dignity and personal virtue (Baroja 1965:82 -84; Pitt-Rivers 1977:22, 40; Gilmore 1990:44--47). Since '[t]he male members ... stand collective guard over the honour of their women' (Wolf 1969:288), an honourable man should be able to defend the honour of his family's female members, 'his wife and daughters should be chaste' (Davis 1977:92; cf Malina \& Neyrey 1991a:42--43; Pitt-Rivers 1977:22; Peristiany 1976:2; Press 1979:117). Should the wife commit adultery, she demonstrates that the husband has failed in his duty to protect her honour. Finally, the man's honour is associated with virility (Press 1979:117)." Renata Rabichev. Op.cit.
} 
maritino, è lecito d'avere amanti e di godersi dei frutti d'amore; e il padre medesimo accarezza l'innamorato della figliuola, e il fratello della sorella, di maniera che niuna porta la virginità al marito. ben vero che come una è maritata gli amatori non la seguono più, ma si danno a un'altra. ${ }^{139}$

Nesse trecho há uma dupla interpretação. Não há como garantir uma única definição para a ideia marcante que Leão Africano ressalta aqui. Considerando que o autor queira impressionar o leitor com a falta de zelo dos cidadãos da Berberia em relação ao pudor de suas mulheres, o sentido dado à palavra "l'innamorato" pode ser metafórico. É possível que Leão Africano esteja se referindo ao fato de que os pais mimam, ou agradam, aos "amores" (amantes) de suas filhas; ou ao fato de que os pais "acariciam" o "amor" de suas filhas, ou seja: de que mantém relações sexuais com as jovens antes de seus maridos. No cotejo com a tradução espanhola ${ }^{140}$, reforça-se o primeiro sentido, enquanto que, na tradução francesa ${ }^{141}$, sugere-se o segundo. De todo modo, a questão central a ser discutida é o lugar ocupado pela virgindade na classificação moral dos nativos feita por Leão Africano. Atrelada ao comportamento lascivo das mulheres das montanhas da Berberia encontra-se uma série de atributos depreciativos de outra ordem, direcionados também aos homens da região, tais como: "bestiais, ladrões e ignorantes", além de miseráveis. A falta de pudor sexual das mulheres é reflexo de uma sociedade moralmente doente, o que faz com que se estabeleça na narrativa uma íntima relação entre desgraça material e corrupção moral.

Em termos gerais, Leão Africano sugere, de modo sutil, uma conexão entre conduta moral e prosperidade econômica que possui a virgindade feminina como um dos indícios do grau de moralidade de determinada sociedade, como no caso dos povos das montanhas da Berberia. Já quando descreve os costumes e modo de vida dos africanos que habitam os desertos da Líbia, o viajante granadino revela:

\footnotetext{
"Dipoi beonsi una tazza di latte, e questo è il fine della cena. E mentre dura loro il latte non si curano altrimente di acqua, massimamente la primavera, in tutto il tempo della quale si trova alcuno fra loro che non s'ha lavato né mani né viso: e questo aviene sì perché in quella stagione essi non vanno alla campagna ove è l'acqua, avendo come s'è detto il latte, e sì ancora perché i camelli, quando mangiano
}

\footnotetext{
139 "Os pastores, tanto os montanheses, como os dos campos, vivem amargamente de seus trabalhos manuais, e seguem em permanente miséria e necessidade. São bestiais, ladrões e ignorantes; não pagando nada que lhes dê a crédito. São, majoritariamente corno que de outra sorte. A todas as jovens, antes do matrimônio, é permitido ter amantes, e gozar a fruta do amor; o próprio pai acaricia o amor de sua filha, e o irmão ao de sua irmã, de modo que nenhuma jovem entrega sua virgindade ao marido. Também é verdade que, uma vez casada, seus amantes deixam de seguir a mulher, mas acabam entregando-se a outra."

${ }^{140}$ Serafin Fanjul. Op.cit.

${ }^{141}$ Jean Temporal. Op.cit.
} 
l'erbe, non sogliono bere acqua. La vita loro fino al dì che muoiono è posta tutta o in cacciare o in rubbare i camelli dei loro nimici ${ }^{142}$ "

Sejam aqueles que não guardam a castidade de suas mulheres para os maridos, ou aqueles que não se lavam e roubam os camelos dos inimigos, os africanos de diversas regiões são avaliados por padrões éticos que refletem níveis econômicos compatíveis ao julgamento moral depreciativo de Leão Africano. De todo modo, tornando evidente a centralidade da questão do pudor sexual das mulheres e da importância do zelo de certo sistema de valores sustentado pelo binômio honra/vergonha, a reputação feminina é um dos elementos mais fortes da tradição árabeislâmica presentes no texto de Leão Africano.

Como visto na passagem sobre os povos das montanhas da Berberia, a virgindade feminina é o principal tabu constantemente salientado pelo viajante. A incidência de grupos sociais magrebinos que mantêm seus próprios rituais de defloração, muitas vezes não reservados aos maridos, pode ser um fator explicativo para o assombro contínuo de Leão Africano em relação a essa questão, já que, como muçulmano granadino, e, posteriormente, cristão converso, a sexualidade feminina exercida antes do casamento é execrável. Malek Chebel destaca a existência de tradições sexuais não compatíveis à normatização moral islâmica nas montanhas do Atlas argelino, região que coincide parcialmente com o que Leão Africano chama de Berberia $^{143}$, e grande parte dessas tradições criam rituais em que as mulheres são defloradas por homens providos de respeitabilidade social, e não por seus próprios maridos.

Mas, ainda no tocante ao uso do binômio honra/vergonha na construção de um discurso moral atrelado ao progresso econômico de determinado povo, a descrição que Leão Africano faz das mulheres que vivem no deserto líbio é contumaz:

\footnotetext{
142 "Depois bebem um copo de leite, e isso encerra o jantar. Enquanto dura o leite, eles não se preocupam com a água, principalmente na primavera. Ao longo desse período algumas pessoas não lavam as mãos e nem a cara, porque nessa estação do ano os númidas não se deslocam para regiões em que haja água, contando com o leite, e também pelo fato de que os camelos, quando comem ervas, não precisam beber água. Por toda a vida, até a morte, entregam-se à caça ou ao roubo dos camelos de seus inimigos."

143 "En Magreb, el marido se reserva la prerrogativa de gozar enteramente del primer coito (y de los siguientes), y no admite en ningún caso que esta exclusividad se extienda a otros. Pero ciertos testimonios recurrentes enturbian un poco el agua clara de esta realidad. En las montañas del Atlas sahariano argelino, entre los montes Ksur y Amur, no lejos de los montes Uled Nayl, se ha observado una desfloración ritual. Nos enteramos de que 'es muy halagador, muy honorable que una niña sea desflorada por un hijo de gran tienda... sobre todo si pertenece a una familia de morabitos." Malek Chebel. Op. cit. p. 92.
} 
"I gentili uomini di questo popolazzo portano pure in capo, com'io ho detto, un drappo negro e con una parte di quello cuoprono il viso, ascondendo ogni sua parte eccetto gli occhi: e ciò portano continuamente, laonde, quando mangiar vogliono, per ogni volta che si mettono il mangiare in bocca scuoprono la bocca, e mangiato che hanno se la tornano a coprire. Adducono esser di questo uso la ragione che, sì come è vergogna all'uomo di mandare il cibo fuora, così è vergogna quando lo mette dentro. Le lor femine sono molto compresse e carnute, ma non molto bianche. Hanno le parti di dietro pienissime e grasse, così le poppe e il petto; dove si cigne sono sottilissime. ${ }^{144,,}$

O viajante começa o trecho destacando certo recato dos homens durante a alimentação. Independente dos motivos que levam a tal zelo, a preocupação com a infâmia social é louvada no texto. Quanto às mulheres, a descrição física das mesmas indica o apreço de Leão Africano, certamente porque a opulência dos corpos dessas mulheres é compatível com o ideal de beleza e sensualidade feminina dos árabes do século XVI. Mas, o que fica subtendido nessa passagem é que a junção física de seios e nádegas avantajadas com cintura fina é um signo instintivo claro de fertilidade, o que coloca essas mulheres em condição de destaque na lógica moral de Leão Africano. A fartura dos corpos, que é expressão da abundância de recursos alimentares e da valorizada vida ociosa feminina, transforma-se em sinal de prosperidade econômica, e, portanto, melhor status moral a esse grupo humano em relação a outros povos descritos.

Ao expor seu desejo pelo padrão físico de um grupo de mulheres líbias, Leão Africano retoma o discurso de valorização da fecundidade como padrão da honra feminina. E se os homens de qualquer parte da África não exercerem sua honradez masculina por meio da virilidade que lhes cabe, parece que Leão Africano encontra-se disposto a oferecer-se ao doce ofício de ser verdadeiramente "o africano" honrado e viril.

\subsection{Enterrar a cabeça na areia: a experiência da incerteza no pensamento algébrico de Leão Africano}

Além do binômio honra-vergonha e do sentido de Fortuna, as tradições árabeislâmica e latino-cristã também podem ser vistas, no relato de Leão Africano, na maneira com que o viajante organiza sua leitura racional do mundo. A formação erudita dos intelectuais do século XVI valorizava um tipo de relação abrangente com o

\footnotetext{
144 "Os gentis homens dessa população portam na cabeça, como já disse, uma faixa negra, cobrindo a cara com uma parte desse tecido, escondendo-a, salvo os olhos. Somente se descobrem quando comem, pelo tempo que gastam para meter a comida na boca. Justificam esse costume argumentando que assim como é vergonhoso ao homem expelir o alimento, também é infame metê-lo para dentro. Suas mulheres são baixas e carnudas, mas não muito brancas, com traseiros volumosos e gordos, assim como os peitos, que usam bem apertados; mas de cintura fina."
} 
conhecimento. O homem de letras era caracterizado como um douto em reflexões de ordens distintas, não havendo separações disciplinares profundas entre conhecimentos como filosofia, música, astrologia e matemática, por exemplo. De certo modo, a expansão territorial dos impérios medievais e modernos definiam os caminhos do conhecimento desenvolvido pelos seus estudiosos, já que o legado cultural dos povos conquistados podia ser incorporado às reflexões dos integrantes do novo império.

Nesse sentido, a matemática pode servir como um exemplo de um tipo de espólio reflexivo que se desenvolveu a partir da anexação de regiões distintas da África e da Ásia aos impérios islâmicos após o século VII. A herança da matemática desenvolvida por tradições culturais como as dos babilônios, egípcios, persas, gregos e romanos, por exemplo, foi absorvida pela estrutura administrativa da expansão islâmica na Ásia e na África, sendo congregada ao legado muçulmano. Com o tempo, principalmente a partir do esplendor da cultura islâmica em territórios distintos como o Norte da África, o Oriente Médio e a Península Ibérica, os referidos intelectuais puderam reunir e aprimorar grande parte do conhecimento matemático produzido pela humanidade, em um processo de valorização da matemática prática e teórica chamada,

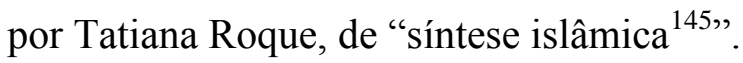

A matemática como ferramenta facilitadora dos problemas práticos adquiriu condições para seu desenvolvimento principalmente a partir de sua racionalização em equações com valores desconhecidos. As questões cotidianas que invocavam a necessidade de se desvendarem incógnitas como, por exemplo, os cálculos de heranças ou qualquer divisão de quantidades em proporções distintas, somadas às práticas de tradução sistemática de textos da Antiguidade Clássica foram os motores da ampliação do conhecimento matemático nos territórios islâmicos.

Uma das áreas do pensamento matemático que mais se beneficiou desse processo de ampliação do conhecimento no Islã foi a álgebra. As inovações produzidas pelos matemáticos islâmicos seguiram o fluxo de expansão e retração do pensamento científico plural vivido pelos muçulmanos. Quando as posições mais conservadores e dogmáticas assumiam o controle da estrutura política dos impérios islâmicos, a produção científica e cultural não estritamente corânica ou religiosa se deslocava para

\footnotetext{
145 "Juntamente com a cultura científica grega, essas diferentes tradições teriam convivido no período préislâmico, porém sem alcançar o grau de desenvolvimento e criatividade que marcou os primórdios da época de ouro do islã, iniciada no século IX. Podemos chamar, portanto, de síntese islâmica a conscientização sobre a relevância e as potencialidades da matemática prática e da matemática teórica quando aplicadas a problemas, métodos e resultados uma da outra." Tatiana Roque. História da matemática: uma visão crítica, desfazendo mitos e lendas. Rio de Janeiro: Zahar, 2012. p. 244.
} 
outras áreas, fazendo com que, em épocas distintas, terras como Bagdá, Isfahan, Córdoba, Fez e Cairo abrigassem grandes pensadores que contribuíram para as mais variadas formas de conhecimento, e, entre elas, a álgebra. Sobre essa questão, Tatiana Roque afirma:

\begin{abstract}
“Fala-se muito na matemática produzida na região de Bagdá, ou no Irã, mas desde os anos 1980 a história da matemática tem se dedicado também às práticas matemáticas desenvolvidas no chamado Ocidente muçulmano, que inclui a Andaluzia e o Magreb. Esses pesquisadores, dentre os quais Ahmed Djebbar se destaca, procuram mostrar que a recuperação dessa história esquecida pode ter uma função política - a de favorecer o reconhecimento de uma cidadania mediterrânea que permita pacificar os conflitos existentes na região. Entre os séculos XII e XV, Marrakech era um polo de desenvolvimento científico, unificando as culturas africanas e europeias localizadas em torno do Mediterrâneo, sem distinção entre muçulmanos, judeus e cristãos. ${ }^{146 "}$
\end{abstract}

A produção de conhecimento com a participação de comunidades religiosas e culturais distintas efetivamente é uma característica que incidiu no pensamento matemático aprimorado pelos pensadores das terras islâmicas. É claro que o elogio à paz e à cordialidade entre grupos sociais distintos é um exagero ao se considerar a maneira como os homens entendiam as diferenças, principalmente religiosas, entre os séculos XII e XV. Entretanto, Tatiana Roque afirma que o surgimento de questões da vida prática compartilhadas por povos da região do Mediterrâneo favoreceu o florescimento do pensamento algébrico entre os homens do Magreb e de al-Andaluz, por exemplo.

A álgebra elaborada por pensadores islâmicos desenvolveu-se a partir de trabalhos consagrados na Antiguidade Clássica, como os de Euclides, Ptolomeu e Diofanto, produzindo soluções a equações apresentadas em linguagem exclusivamente retórica, sem nenhum tipo de símbolo. Essa álgebra retórica foi uma forma de se construir e organizar o pensamento que ganhou força a partir da criação do método algébrico de al-Kwarizmi, um matemático muçulmano de origem persa que defendeu certa autonomia da álgebra em relação à geometria entre os séculos VIII e IX. A contribuição dos matemáticos do Magreb posteriores a al-Kwarizmi foi justamente a inclusão de símbolos aos algoritmos de resolução de equações, aperfeiçoando o estilo eminentemente retórico da álgebra ${ }^{147}$. A finalidade dessa prática era aproximar as

\footnotetext{
${ }^{146}$ Idem, pp. 247-248.

147 "No entanto, a versão simplificadora sobre a difusão da álgebra na Itália teve de ser reformulada nos últimos anos devido a dois complicadores: as descobertas que exibem o desenvolvimento de uma álgebra simbólica no Magreb e na Andaluzia entre os séculos XI e XIV, bem como sua transmissão para os cristãos da Espanha; e as pesquisas em torno das escolas de ábacos, que floresceram na Itália a partir do século XIII.” Idem, p. 262.
} 
reflexões algébricas dos problemas matemáticos que as relações comerciais impunham aos muçulmanos do Norte da África e da Península Ibérica.

A substituição de incógnitas e valores incertos por símbolos favoreceu, entre árabes e muçulmanos, a formação de um tipo de pensamento que não separava abruptamente a retórica argumentativa da necessidade de se trabalhar com incertezas. Assim como a álgebra se baseava em métodos para se encontrarem valores não conhecidos, as demais formas de se pensar o mundo como a geografia moderna e seus relatos de viagem podiam incorporar contextos de imprecisão em suas narrativas.

A ressonância dessa forma de se fundamentar a natureza reflexiva do homem não ficou restrita ao Mediterrâneo islâmico, mas atingiu também a Península Itálica cristã, que nos primórdios da modernidade já havia reconhecido a importância dos estudos de cálculos matemáticos. As necessidades comerciais que conferiram novo status à matemática e, mais especificamente, à álgebra entre os muçulmanos, também atingiu as cidades italianas. O desenvolvimento econômico de grandes centros de comércio como Gênova, Veneza e Florença passou a depender de indivíduos habilidosos com números, o que levou os estudos de álgebra, geometria prática e contabilidade à condição de necessidades operativas ${ }^{148}$. É claro que a matemática e, em especial, a álgebra não foram aprimoradas apenas quando submetidas ao uso técnico comercial. A busca pela resolução de problemas lúdicos de cálculo como jogos, enigmas e exercícios racionais curiosos também fizeram parte do desenvolvimento do pensamento algébrico nesse período.

A junção entre importância comercial e lúdica de desafios matemáticos permitiu que os duelos públicos de conhecimento de cálculo fossem muito populares na Itália do século XVI. A dinâmica desses duelos presumia que dois matemáticos propusessem entre si um conjunto de problemas e enigmas, sendo que aquele que conseguisse resolver as questões do adversário mais rapidamente vencia a disputa. A única regra moral era que nenhum dos duelistas podia indicar ao rival um problema que não soubesse resolver. Em questão estavam a honra dos envolvidos na contenda e o aumento de sua reputação como grande mestre da matemática, o que conferia aos

\footnotetext{
148 "Portanto, segundo os já citados Gamba e Montebelli, o ensino do cálculo inculcava nos alunos 'uma mentalidade mnemônico-analógico-operativa, e não lógico-dedutiva, muito indicada para o exercício da mercancia, que apresentava situações em que, rapidamente, era preciso fazer as contas no próprio bolso e no bolso alheio." Fabio Toscano. A fórmula secreta: Tartaglia, Cardano e o duelo matemático que inflamou a Itália da Renascença. Campinas: Editora UNICAMP, 2012. p. 32.
} 
vencedores bons empregos nas universidades e o aumento do número de alunos e discípulos.

No interior dessa disputa pública pelo reconhecimento da condição de maior matemático da Itália renascentista encontrava-se o desafio de se descobrir uma fórmula geral para a resolução de equações algébricas de terceiro grau, que à época podiam ser resolvidas apenas por meio de casos específicos de exemplos geométricos. Um dos matemáticos que se dedicou a esse propósito no século XVI foi Niccolò Fontana, conhecido como "Tartaglia"149. A partir de 1530, quando um matemático rival chamado Zuanne de Tonini da Coi lhe propôs dois problemas que necessitavam a resolução de equações cúbicas, Tartaglia passou a se dedicar mais intimamente aos enunciados algébricos de terceiro grau. Antes de produzir resultados significativos nesse campo, seu principal trabalho foi na área da balística, quando concluiu que o alcance máximo de um projétil poderia ser obtido ao ser disparado por uma arma com inclinação de 45 graus em relação ao horizonte.

Enquanto Tartaglia refletia sobre equações algébricas cúbicas, superando outros matemáticos de sua época como Antonio Maria Fior e Scipione del Ferro, outro mestre italiano, Girolamo Cardano, também se dedicava ao intento de conhecer a fórmula secreta das equações de terceiro grau. Tartaglia e Cardano se aproximaram por causa do interesse comum pela álgebra. Cardano havia escrito um tratado sobre equações algébricas de primeiro e segundo graus, e, posteriormente, decidiu incluir capítulos sobre soluções de equações cúbicas. Como não conhecia uma fórmula resolutiva geral para as mesmas, procurou Tartaglia, com a intenção de que ele revelasse seus conhecimentos sobre o assunto. Após muita insistência, Tartaglia cedeu seu conhecimento de uma fórmula geral, obrigando Cardano a prometer que não a tornaria pública. Após seis anos de sigilo, Cardano incluiu as informações da fórmula resolutiva de Tartaglia e publicou seu tratado de álgebra com o título de Artis Magna Sive de Regulis Algebraicis (A grande arte, ou as regras da álgebra) em $1545^{150}$.

Para a memorização de seu método geral para equações cúbicas, Tartaglia transmitiu a Cardano um poema cujos versos revelavam as etapas do procedimento de resolução dessas equações:

\footnotetext{
${ }^{149}$ Em italiano, "gago".

150 "Um terceiro matemático italiano, Girolamo Cardano, que parece ter obtido a fórmula de Tartaglia prometendo mantê-la em sigilo, acabou por publicá-la em 1545 no livro Ars magna (a grande arte), onde trata a solução de cada um dos treze tipos de equação cúbica em capítulos separados." Tatiana Roque. Op.cit. p. 270.
} 
“Quando che'l cubo con le cose appresso se agguaglia a qualche numero discreto: trovan dui altri, diferente in esso.

Dapoi terrai, questo per consueto, che'l loro produtto, sempre sia eguale al terzo cubo della cose neto;

el residuo poi suo generale, delli lor lati cubi, ben sottratti varra la tua cosa principale.

In el secondo, de cotesti atti; quando che'l cubo restasse lui solo, tu osserverai quest'altri contratti,

del numer farai due tal part'a volo, che l'una, in l'altra, si produca schietto, el terzo cubo delle cose in stolo;

delle quali poi, per commun precetto, torrai li lati cubi, insieme gionti, et co tal somma, sará ii tuo concetto;

el terzio, poi de questi nostri cónti, se solve col segundo, se ben guardi che per natura son quasi congionti.

Questi trovai, et non con pasi tardi nell mille cinquecent'e quatro e trenta; con fondamenti ben saldi, e gagliardi; nella cittá del mar'intorno centa. ${ }^{151,}$

A maneira retórica com que a solução algébrica foi proposta por Tartaglia mostra a formação cultural ampla do homem de letras do século XVI, permitindo que as inquietudes comuns aos matemáticos fossem compartilhadas por intelectuais consagrados em outras formas retóricas de organizar o conhecimento sobre o mundo, como Leão Africano e seu relato de viagem.

\footnotetext{
151 "Quando o cubo somado com as coisas/ se iguala a algum número discreto/ encontra nele outros dois diferentes/ Depois verás, num procedimento usual/que o produto deles é sempre igual/ ao terceiro cubo das coisas exato/ O resíduo, então, geral/ de suas raízes cúbicas subtraídas/ Será o valor da tua coisa principal/ No segundo desses atos/ Quando o cubo fica sozinho/ Aplicarás esses outros contratos/ Do número farás duas partes, de modo/ que, multiplicando uma pela outra, surja exato/ o terceiro cubo das coisas em conjunto/ Delas, depois, com procedimento usual/ somarás as raízes cúbicas/ e esse total será o resultado final/ A terceira dessas nossas contas/ resolve-se por meio da segunda, se olhares bem, porque por natureza são quase parentes/ Achei esses, e não com passos lerdos/ em mil quinhentos, quatro e trinta/ com fundamentos bem sólidos e robustos/ na cidade circundada pelo mar." Fabio Toscano. Op. cit. pp. 154-155.
} 
O ponto de convergência entre o pensamento algébrico do século XVI e as reflexões do viajante granadino foi a demonstração de que, seja na matemática ou na escrita geográfica, duas questões mostravam-se cruciais: o problema do comércio e, principalmente, o reconhecimento do caráter incógnito e impreciso do mundo. O papel da álgebra foi, por muito tempo, o de criar estratégias para se chegar a resultados desconhecidos. A geografia de viagens foi uma maneira de se produzir uma resposta ao desconhecimento do homem sobre o mundo, especialmente quando o ímpeto pelo comércio levou os reinos europeus à conquista de terras e povos até então incógnitos. Para a corte do Papa Leão X, a África era uma terra desconhecida comercialmente, a ser revelada, assim como o resultado de equações cúbicas deveria ser conquistado pelos homens.

O fascínio pela superação do desconhecimento uniu Leão Africano ao pensamento algébrico já obcecado, no século XVI, pelo fim das incertezas. A principal característica desse tipo de conhecimento voltado para o fim das imprecisões do mundo é a busca de resultados inquestionáveis e racionalmente constituídos por meio de técnicas lógicas conhecidas como "o fio de Ariadne".

Na mitologia grega, Ariadne era filha de Minos, o rei de Creta, e apaixonou-se por Teseu, herói ateniense enviado em sacrifício para ser devorado pelo filho monstruoso de Minos, o Minotauro, que vivia em um insólito labirinto. A caminho de seu destino nefasto, Teseu foi alvo da paixão arrebatadora de Ariadne, que, para salválo, deu-lhe a ponta de um novelo de lã que seria desenrolado no percurso do labirinto e, assim, marcaria a saída, onde Ariadne estaria, para encontrá-lo. A representação mitológica do fio de Ariadne remete ao poder da lógica na solução de problemas complexos. A partir de situações inesperadas é possível encontrar "fios" de lógica que, ao serem conectados, produzem uma verdade desejável.

Ao longo da descrição que Leão Africano faz da África, a lógica de suas conclusões se adaptam ao desejo de apresentar informações legítimas, mesmo que, em alguns casos, seu fio de Ariadne produza "nós". Um dos exemplos mais evidentes desse jogo lógico de produção de verdades é a descrição que o viajante faz dos reinos da Terra dos Negros:

"Né voglio tacer d'esser stato in quindici regni di terra negra, e tre volte più ce ne sono rimasi di quelli dove io non fui, ciascuno assai noto e vicino a' luoghi ne' quali mi trovava. I nomi di questi regni, togliendo il principio dall'occidente e seguendo verso oriente e verso mezzogiorno, sono tali: Gualata, Ghinea, Melli, Tombutto, Gago, Guber, Agadez, Cano, Casena, Zegzeg, Zanfara, Guangara, Burno, 
Gaogà, Nube. Questi sono quindici regni i quali per la maggior parte sono posti sul fiume Niger, e per quelli fanno la strada loro i mercatanti che partono di Gualata per andare al Cairo. Il cammino è lungo, ma molto sicuro. ${ }^{152,}$

A lógica como solução para a produção de informações desconhecidas foi amplamente utilizada nessa passagem. Inicialmente, Leão Africano confessa que não esteve em parte considerável dos reinos descritos; mas isso não invalida suas observações, já que os reinos que não foram visitados por ele estão bem próximos dos que foram. A aproximação é uma escolha lógica feita a partir de uma alternativa precisa anterior. Ao desconhecer o reino seguinte, deduz-se que a proximidade espacial com um reino conhecido produz argumento coerente de relação retórica, anulando a imprecisão incógnita. Ao invés do silêncio sobre um território não visitado, que conferiria ilegitimidade ao argumento narrativo, volta-se à solução anteriormente dada, ou seja, aos reinos mais próximos que foram frequentados pelo viajante. A verdade final desejada é conquistada voltando-se sempre ao ponto de partida seguro, como Teseu no labirinto desconhecido, e, pouco a pouco, revelado pelo rastro do fio de Ariadne $^{153}$.

Outro elemento significativo da passagem sobre os reinos da Terra dos Negros é a aproximação que Leão Africano faz entre os rios Níger e Nilo. Ao seguir a geografia descritiva de Ptolomeu, o viajante granadino recai em uma imprecisão comum aos seus contemporâneos: a compreensão de que o rio Níger se conecta ao rio Nilo, interligando a Terra dos Negros ao Egito. Na ausência do testemunho concreto sobre o curso completo dos rios, a substituição lógica da experiência pela coerência permite que a conexão entre os rios seja crível, mais do que fisicamente verdadeira. A aceitação do equivoco ptolomaico também está presente em outros viajantes como Ibn Battuta, uma referência lógica anterior que se transforma no fio retórico de Leão Africano para escapar do labirinto geográfico africano. Na ausência da exatidão descritiva, o recuo ao

\footnotetext{
152 "Não escondo o fato de que estive em quinze reinos da Terra dos Negros e que existem três vezes mais deles em que não estive, cada um, bem conhecido e próximo aos que visitei. Os nomes desses reinos, de Ocidente a Oriente e a meio-dia são estes: Gualata, Ghinea, Melli, Tombutto, Gago, Guber, Agadez, Cano, Casena, Zegzeg, Zanfara, Guangara, Borno, Gaoga e Nube, quinze reinos, em sua maioria nas margens do rio Níger; e através deles os comerciantes fazem seu caminho de Gualata para chegar ao Cairo. O caminho é longo, mas muito seguro."

${ }^{153}$ Em sua obra: "O fio e os rastros", Carlo Ginzburg sugere a análise da metáfora do fio de Ariadne no ofício do historiador. A preocupação de Ginzburg é tornar visível o caráter construtivo-lógico da escrita da História. O diálogo desse autor é com as discussões sobre as fronteiras entre o verdadeiro, o ficcional e o falso, questões pertinentes aos historiadores a partir da segunda metade do século XX. O uso da mitologia do fio de Ariadne no pensamento algébrico-retórico de Leão Africano não prioriza os mesmos aspectos de Ginzburg, já que com pretensões modestas, não se discute filosoficamente o limite entre ficção e verdade histórica em Leão Africano, mas apenas tenta mostrar a estratégia de substituição do real por recursos lógicos de aproximação com o testemunho narrativo, elementos condizentes com a percepção do mundo própria do homem do século XVI.
} 
testemunho legítimo de outro viajante ou escritor consagrado é uma estratégia que confere autoridade ao argumento passível de imprecisão.

Os fios do novelo que levam o viajante de um ponto a outro do Mediterrâneo estão conectados por uma fórmula geral algébrico-retórica: o cubo das tradições latinocristãs, somado ao quadrado da honra e da vergonha islâmicas e ao fluxo mediterrâneo de culturas traduzidas resolvem a incógnita africana. 


\title{
4. A África feita de água
}

\begin{abstract}
Parte do desafio consiste em pensar seriamente em Fort-de-France, Quito, La Paz, Bagdá, Argel, e não apenas em Paris, Frankfurt, Roma ou Nova Iorque, como possíveis lugares de conhecimento.

(...) No mundo, há muito para aprender com aqueles outros que a modernidade tornou invisíveis.
\end{abstract} (Nelson Maldonado-Torres)

\subsection{A correnteza do mundo: o comércio}

A pintura renascentista não se esqueceu dos detalhes transformadores da vida humana no século XVI. No primeiro capítulo desse trabalho viu-se o tema religioso como premissa para distintas visões da arte do período. No segundo capítulo, o "santo" concede lugar ao "homem" humanista, repleto de símbolos profanos que o caracterizam. Nesse terceiro capítulo, a pintura é invocada para prestar a devida reverência a outro universo próprio do século XVI: as relações comerciais.

O tema do comércio aparece em algumas telas entre os séculos XVI e XVII, principalmente nos trabalhos de pintores holandeses. Segundo Carlos Pérez Vaquero, Quentin Matsys é herdeiro da tradição pictórica flamenca que privilegia "escenas de género", ou seja, a representação de temas domésticos e cotidianos ${ }^{154}$. No interior desse contexto artístico desenvolvido ao longo do século XVI surge como exemplo mais evidente da afirmação do comércio e das finanças como tema da arte pictórica o quadro O cambista e sua mulher (1514), de Matsys.

A primeira questão que pode ser levantada a partir da referida obra é o fato de que ela não está sozinha. O cambista e sua mulher serviu de modelo para outras obras posteriores, principalmente por causa do tema proposto por Matsys. Em 1539, outro

\footnotetext{
154 “En ese contexto histórico nació Quentin Massys en Lovaina (actual Bélgica) hacia 1465. Desde su escuela-taller de Amberes, logró que sus obras mantuvieran la tradición de los grandes pintores flamencos pero aportándole los gustos del Renacimiento italiano y ciertas dosis de sátira. Como amigo de Erasmo de Rótterdam, se dice que siguiendo los criterios del humanista empezó a pintar escenas de género -término con el que se conocen las representaciones de temas domésticos y cotidianos-centrados en banqueros, contables, recaudadores de impuestos y mercaderes como este pequeño óleo sobre tabla, pintado en 1514, titulado El cambista y su mujer que actualmente se conserva en el Museo del Louvre (París). Carlos Pérez Vaquero. El cambista y su mujer, de Quentin Massys. Revista Contabilizarte. IV Trimestre, 2010. p. 26.
} 
pintor holandês, Marinus van Reymerswaele elaborou uma tela cujas semelhanças com a obra de Matsys não se limitaram ao título:

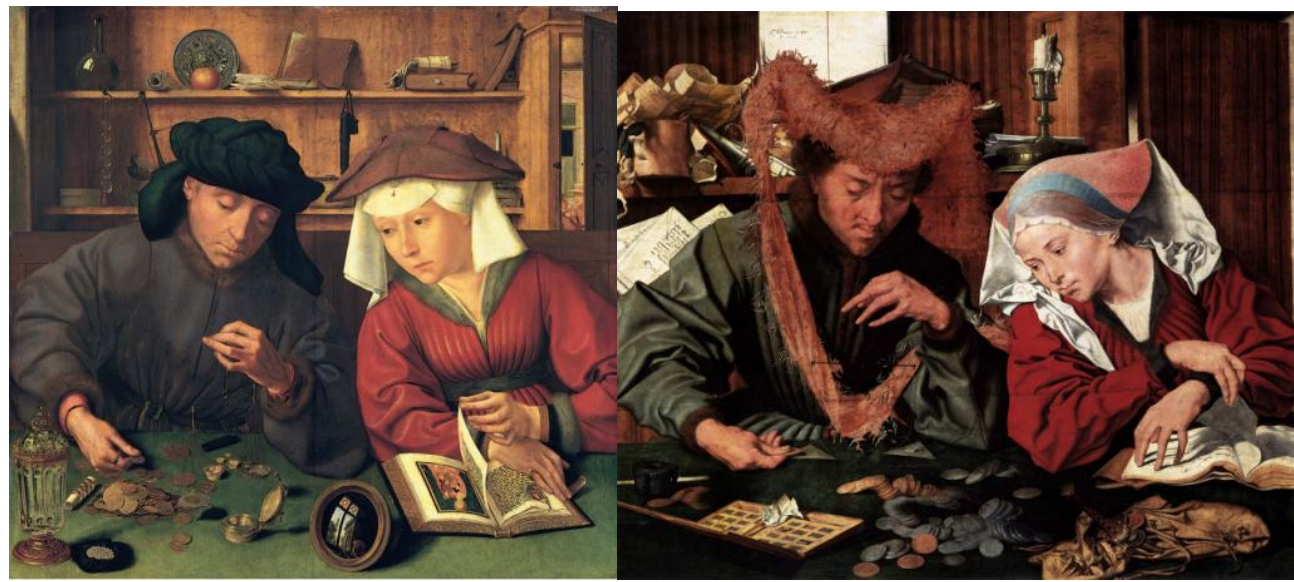

Quentin Matsys (1514)

M. van Reymerswaele (1539)

Uma vez exposta a importância do tema por sua recorrência, cabe analisar os elementos simbólicos utilizados por Matsys em sua tela. Ao se concentrar na primeira obra, três signos mostram-se relevantes: a ação do cambista, a ação da mulher, e o estranho objeto em destaque, localizado entre os dois personagens: um espelho convexo.

Como um cambista do século XVI, a figura masculina analisa detalhadamente as características das moedas. Os pesquisadores que se debruçam sobre esse aspecto da obra chegam a conclusões distintas sobre a simbologia da ação do personagem. Existem duas correntes interpretativas conflitantes possíveis: aqueles que encontram na maioria das obras de Matsys aspectos moralizantes e satíricos; e os que apenas contextualizam o tema, atribuindo o motivo da tela à ascensão da burguesia comercial no século XVI, ou apenas ao registro simples do ofício dos homens de negócio. Em seu artigo sobre a representação da contabilidade em O cambista e sua mulher, Manuel Santos Redondo afirma que essa obra de Matsys pode ser situada no interior de uma disputa interpretativa entre o que os historiadores compreendem e o que defendem os contabilistas. Para Redondo, os historiadores da arte encontram na arte flamenca um vínculo com a mensagem da Escolástica de São Tomas de Aquino, em que a materialidade funciona como uma representação metafórica da espiritualidade. Nas palavras de Redondo:

"El historiador del arte Erwin Panofsky (Early Netherlandish Painting, 1953) sostuvo que los pintores flamencos del Renacimiento tenían que reconciliar el "nuevo naturalismo" con mil años de tradición cristiana. Basándose en Santo Tomás de Aquino, que pensaba que los objetos físicos eran "metáforas corpóreas de cosas espirituales", Panofsky sostiene que "en la pintura primitiva flamenca, el método del simbolismo disfrazado se aplicaba a todos y cada uno de los objetos, fueran naturales o hechos por el hombre". 
Em contraposição ao que chamou de "prejuicio de muchos historiadores del arte hacia el mundo del comercio", Redondo defende que Matsys queria apenas mostrar o que para ele é óbvio: la actividad comercial y financiera como una profesión normal y respetable. ${ }^{155 ", ~ Q u a n d o ~ o s ~ o l h a r e s ~ d e ~ a m b o s ~ o s ~ l a d o s ~ d e s s a ~ d i s p u t a ~ s a ̃ o ~ a p l i c a d o s ~ a ̀ ~ a c ̧ a ̃ o ~}$ do personagem masculino da pintura, o problema não se resolve. Os "contabilistas" representados aqui por Redondo afirmam que a maneira meticulosa com que o cambista analisa as moedas é sinal de que o personagem exerce o seu oficio com esmero, tentando identificar a autenticidade das moedas. Já os "historiadores" afiançam que o cuidado do personagem pode ser visto como sinal de avareza, um tema comum ao homem do século XVI, que tenta conciliar vida profana com tradição cristã.

O embate não se resolve com a interpretação da simbologia das moedas, mas pende em favor dos "historiadores" na análise da ação da mulher. Os olhos da esposa se concentram na mão do cambista, fazendo com que ela se torne displicente em relação à sua própria ação. Mas o que as mãos da mulher revelam ao observador da tela?

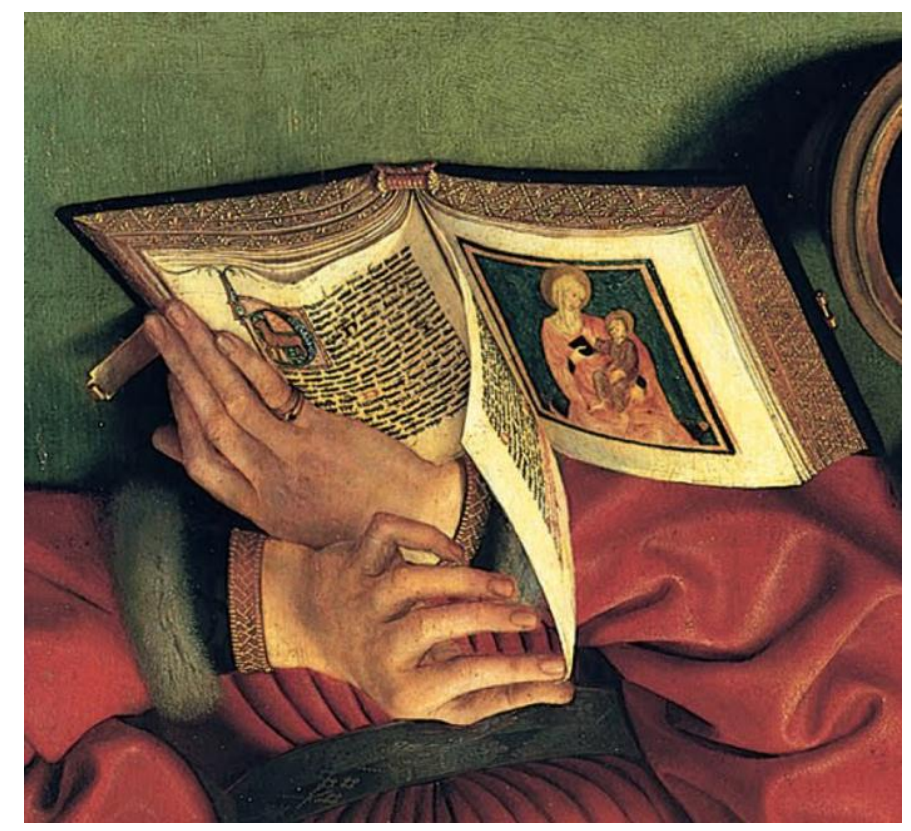

\footnotetext{
155 "Al revisar las diferentes interpretaciones proporcionadas por los historiadores del arte sobre este cuadro y otros similares, hemos visto que la mayoría de ellas se corresponden con la visión que muchos historiadores del arte tienen del mundo del comercio y del dinero, más que basarse en una interpretación objetiva de la pintura y de la historia. Así, mientras el cuadro muestra la actividad comercial y financiera como una profesión normal y respetable, la mayoría de los historiadores del arte le atribuyen una interpretación satírica y moralizante. Este artículo sostiene que el prejuicio de muchos historiadores del arte hacia el mundo del comercio y del dinero les conduce a una interpretación equivocada de las pinturas." Manuel Santos Redondo. El cambista y su mujer: de la Escolástica a la contabilidad. Documento de trabalho ou informe técnico. Biblioteca Universidad Complutense de Madrid. http://eprints.ucm.es/6724/
} 
A imagem não deixa dúvidas. Quando invertida em $180^{\circ}$ pode-se ver que as mãos da mulher estão postas sobre um livro religioso que contém na folha direita a imagem do menino Jesus no colo de Maria. O conteúdo moralizante do quadro de Matsys fica mais claro ao se considerar que a mulher abandona a leitura do texto religioso para desviar sua atenção à manipulação das moedas feitas pelo cambista. A atitude reprovável da mulher é uma mensagem moralizante intensa.

Se o tema da atividade do cambista se repete na pintura do século XVI, e ao final a mensagem da obra está ligada aos novos métodos comerciais vividos pelo homem renascentista, pode-se considerar que a expansão do trato é uma questão cada vez mais importantes aos homens e instituições desse período.

Por último, após uma resolução não definitiva da polêmica "historiadorescontabilistas" proposta por Redondo, um último detalhe simbólico da obra $O$ cambista e sua mulher de Matsys merece um olhar cuidadoso. No meio dos personagens masculino e feminino há um objeto que servirá como elemento indiciário da relação entre comércio e poder no século XVI. No centro da mesa em que o cambista e a mulher interagem com gestos e olhares destaca-se um espelho redondo convexo que possui uma função essencial na mensagem satírico-moralizante da tela de Matsys.

Antes mesmo de se analisarem os símbolos contidos nessa peça torna-se oportuno ressaltar que o espelho convexo não é um elemento descolado do contexto de produção do século XVI. De acordo com Carlos Santos, desde o século XIV era corriqueira a fabricação desse objeto, baseada em uma técnica específica aplicada ao sopro de globos de vidro que, quando ainda estavam incandescentes, recebiam camadas de estanho, antimônio e resina. Esse método de elaboração dos espelhos convexos teria nascido na Alemanha e chegado à Itália ainda no século XIV com a introdução desse conhecimento entre artesãos do ramo em Veneza ${ }^{156}$. A contribuição veneziana para a manufatura de espelhos convexos é menos técnica e mais voltada à popularização desse objeto. Em pleno século XVI, Veneza já havia construído sua imagem de grande produtora de espelhos com a formação de um mercado extremamente lucrativo. Para um homem do século XVI, principalmente para os artistas renascentistas, reproduzir em

\footnotetext{
156 "No sul da Alemanha, durante o século XIV, era comum a fabricação de pequenos espelhos convexos. A técnica para a elaboração destes objetos implicava em soprar globos de vidro, que ainda quentes, recebiam na superfície interna uma mistura de estanho, antimônio e resina ou breu. Depois de frios e revestidos completamente com a composição metálica, os globos eram cortados em lâminas convexas, que reproduziam imagens pequenas e bem definidas. No ano de 1317, um mestre alemão na fabricação de espelhos instruiu artífices venezianos". Carlos Alberto Ávila Santos. Espelhos e reflexos: uso e representação em obras artísticas. X Seminário de História da Arte. Vol. 1. No. 1. 2011. p. 1.
} 
suas telas um objeto tão fascinante que refletia a realidade visível era um desafio. Esse contexto da produção de espelhos em Veneza, a constituição de um extenso mercado do produto e o fascínio que a mercadoria exercia sobre os homens da época explicam a recorrência dos espelhos como símbolos pictóricos na arte do século XVI, principalmente entre os holandeses (como no caso de Matsys).

Quando observada detalhadamente, a imagem do espelho convexo redondo sobre a mesa revela uma nova simbologia satírico-moralizante:

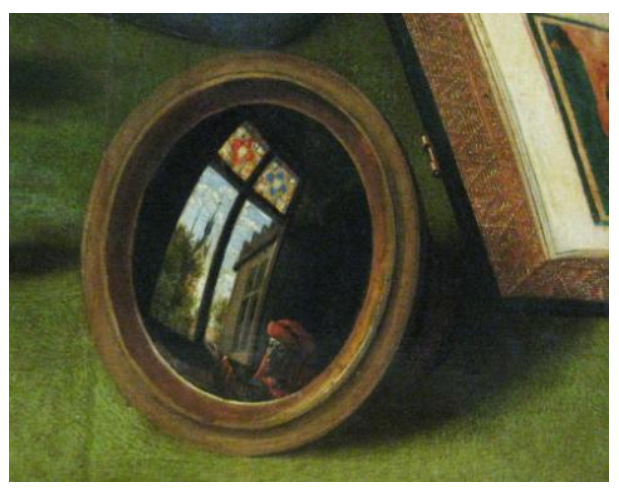

No detalhe vê-se que o espelho convexo reflete outra cena que se relaciona com a cena principal por estar exatamente no lugar de quem observa a tela. Desse modo, do ponto de vista do observador, a cena da avareza de $O$ cambista e sua mulher se realiza, ao passo que tanto o observador quanto os elementos representados no espelho são ignorados pela atenção exclusiva que os personagens centrais da tela destinam ao dinheiro.

A vista apresentada pelo espelho revela uma longa janela com uma figura humana segurando um livro. Da janela vê-se um espaço urbano que abriga a torre de uma catedral e um pedaço de uma construção. O campanário do templo, se tomado separadamente, não apresenta nenhum indício de sua função simbólica além da representação do espaço urbano. Mas, quando combinado ao batente da janela em forma de uma grande cruz alongada e curvada pela superfície convexa do espelho, a torre da catedral e a cruz-batente que se ocultam na cena, observando os personagens principais da tela mostram mais elementos que reforçam o caráter moralizante cristão da obra. Tanto o personagem do cambista quanto a mulher não se dão conta de que estão sendo observados literalmente pela "Igreja".

Já o homem que aparece no espelho tem a cabeça coberta por algum tipo de chapéu que não pode ser facilmente identificado. As especulações sobre quem seria esse 
personagem são distintas e controversas. Uma das mais extravagantes pertence novamente ao "contabilista" Manuel Santos Redondo, que, ao polemizar, afirma:

"Fijemos nuestra atención en un detalle. En la parte inferior del cuadro hay un espejo circular, un elemento usual en los cuadros de esta escuela. En él vemos reflejada la figura de un hombre que lleva un turbante. [Figura 2]. Por no se sabe qué razón, esta es la explicación que da Jean-Claude Frère: "El espejo circular ... refleja una ventana, bajo la que podemos distinguir la figura diminuta de un ladrón. Parece estar espiando a la pareja mientras cuenta su oro, mientras ellos no son conscientes de su presencia, cegados por su codicia". Dejemos de momento la cuestión de la codicia y concentrémonos en la figura diminuta: ¿es un ladrón? Desde luego que no. ${ }^{157,}$

Em parte, Redondo tem razão quando afirma que não há um único elemento que confirme tratar-se de um ladrão. Há certo exagero na explicação simbólica defendida por Jean Claude-Frère. O problema é que ao desconstruir a análise de Claude-Frère, Redondo não apresenta nenhuma outra explicação crível para a figura do espelho. Para Redondo, no espelho apenas “...vemos reflejada la figura de un hombre que lleva un turbante ${ }^{158,}$.

A discussão sobre o que representa o homem refletido no espelho que segura um livro e observa a cena principal da tela deve se basear nos elementos consistentes da simbologia pictórica. O que se tem materialmente exposto no quadro é o homem com um chapéu, segurando um livro. A resposta mais óbvia, às vezes, pode ser a mais oportuna, já que se o cambista é um negociante, sobretudo, o homem com um livro na mão que o observa pode ser simplesmente um cliente. Mas, o fato de esse freguês portar um livro faz com que ele não seja apenas um mero cliente. Pela posição social notável do personagem, perceptível pelo chapéu como signo social holandês, pode tratar-se de um mercador em busca de crédito que segura seu livro de contas para apresentá-lo ao usurário. O Dicionário do Renascimento Italiano editado por John Hale, no verbete sobre métodos comerciais, atribui ao humanista Leon Battista Alberti a seguinte frase: “(é)... adequado a um mercador ter sempre as mãos sujas de tinta. ${ }^{159, "}$

Desse modo, o personagem que interage com o cambista e sua mulher parece carregar consigo a contabilidade de seus negócios, e essa hipótese interpretativa pode ser entendida como mais coerente com o tema da obra do que as demais suposições. $\mathrm{O}$ fato é que o mundo dos negócios do século XVI está presente em mais ambientes e situações sociais do que apenas como anotações contábeis de um profissional. Da

\footnotetext{
${ }^{157}$ Manuel Santos Redondo. Op. cit. p. 2.

158 Idem ibídem.

${ }^{159}$ Verbete: Métodos Comerciais. (IN): John Hale (ed.) Dicionário do Renascimento Italiano. Rio de Janeiro: Jorge Zahar Editor, 1988. p. 233.
} 
pintura aos tratados acadêmicos, o mundo do comércio se expande por toda a Europa. Por essa razão o período do Renascimento viveu a passagem das questões comerciais e contábeis para o universo acadêmico. A necessidade de maior controle de grandes operações internacionais de dinheiro movidas pelo comércio ultramarino fez com que técnicas de trato fossem criadas nessa época. Os italianos, principalmente toscanos e venezianos, são aceitos como os inventores de um sistema de registro de negociações financeiras conhecido como "partidas dobradas" (partita doppia) ${ }^{160}$. Trata-se de um elemento básico da contabilidade moderna que assegura que a soma de todos os valores debitados de uma conta é sempre igual aos valores creditados somados, criando equilíbrio no balanço patrimonial de uma empresa ou organização. Se os valores creditados superarem os debitados, a firma tem saldo positivo. Se ocorrer o contrário, saldo negativo. De qualquer maneira, seja pelo sistema de partidas dobradas ou qualquer outro, todo o procedimento era marcado em livros de notas que, para se conseguirem empréstimos, deveriam ser apresentados ao agiota. Assim, o livro nas mãos do personagem de Matsys pode encaixar-se nessa conjectura.

O financiamento de aventuras comerciais era comum em um século XVI que se fascinava pelo sucesso das Grandes Navegações e do comércio com o mundo nãoeuropeu. O domínio de territórios coloniais pelos Estados nacionais modernos do período era uma prerrogativa de poder que animava as relações políticas, econômicas e militares entre comunidades políticas como Gênova, Veneza, Florença, Império Habsburgo, Império otomano, França, entre outros. A disputa marítima pelo controle do Mediterrâneo se justificava no universo de relações comerciais do Renascimento, o que valorizava qualquer informação precisa sobre as potencialidades econômicas de uma dada região do mundo fora da Europa. O já citado Dicionário do Renascimento Italiano, ainda no verbete sobre métodos comerciais, cita o primeiro Tratado sobre seguro marítimo, o Tractatus Perutilis et Quotidianus de Asecuratostinus et sponsionibus

\footnotetext{
160 "Contudo, naquela época, há muito que frei Luca di Borgo, cujo verdadeiro nome era Luca Pacioli, forneceu, no capítulo XI da sua Summa di arithmetica, geometria, proportioni e proportionalità (1494), o modelo completo da contabilidade em partidas dobradas. Dos dois livros essenciais de contabilidade, o Manuale ou Giornale, onde se registram as operações na sua ordem sucessiva, e o livro principal, o Quaderno, onde se inscreve duas vezes cada operação, é este último, redigido em partidas dobradas, que constitui a novidade. Permite obter, a cada momento, um equilíbrio perfeito entre deve e haver. Se o balanço não fica em zero, foi cometido um erro que é preciso procurar imediatamente." Fernand Braudel. Civilização material, economia e capitalismo: séculos XV - XVIII. São Paulo: Martins Fontes, 2009. p. 510. Volume 2 - Os jogos das trocas.
} 
Mercatorum, atribuído ao embaixador português em Florença, Livorno e Pisa, Pedro de Santarém $^{161}$.

Nesse contexto de expansão marítimo-comercial as tensões entre as forças políticas do período foram inevitáveis, e o mar como a fronteira natural que divide a Europa do resto mundo era um campo de batalha militar e intelectual a ser vencido por todos.

\section{2 Águas revoltas: a questão do domínio sobre o mar}

O jogo político internacional do século XVI pode ser entendido pela maneira como nesse período a noção de "espaço" se transforma e se relaciona com as barreiras naturais que a definem: o mar e a terra. Ao analisar as relações políticas na história, Carl Schmitt afirma que "la historia universal es la historia de la lucha entre las potencias marítimas contra las terrestres y de las terrestres contra las marítimas. ${ }^{162 " ~ C i t a n d o ~}$ autores como Ernst Kapp, Jules Michelet e Herman Melville, Schmitt ressalta a importância da conquista de novos espaços pelo homem moderno, o que transforma os limites marítimos da Europa em ambiente de disputa.

O principal e mais próximo limite marítimo do continente europeu foi, historicamente, o Mar Mediterrâneo. Por essa razão, Carl Schmitt defende que a rivalidade entre potências no século XVI teve como palco de conflito as águas mediterrâneas, que, de certo modo, absorveram as questões humanas e políticas das disputas "terrestres" "163. Por mais que o Mar Mediterrâneo tivesse, desde a Antiguidade, o reconhecimento de sua importância política, no século XVI, antes mesmo que todas as potências europeias se embrenhassem impetuosamente na exploração colonial pelos oceanos, todas as forças políticas da Europa utilizaram o Mediterrâneo como uma espécie de "laboratório" de técnicas navais inovadoras e de projetos práticos de colonização. As batalhas navais ocorridas no Mediterrâneo entre a segunda metade do século XV e as últimas décadas do século XVI mostraram que os países europeus já se concentravam no interesse pelo mar como espaço de conflito e poder.

\footnotetext{
${ }^{161}$ Idem Ibidem.

${ }^{162}$ Carl Schmitt. Tierra y mar: una reflexión sobre la historia universal. Madrid: Editorial Trotta, 2007. p. 26.

163 "Pero hemos de demostrar con toda la claridad posible el significado de que un pueblo opte por el mar como elemento distinto en la totalidad de su existencia histórica. Nada mejor que el tipo de batalla naval de entonces pone de manifiesto lo que aquí tratamos y en qué escasa medida cabe hablar del Mediterráneo de aquella época como de una transposición de la existencia humana entera de la tierra al mar". Idem, pp. 31-32.
} 
A relação entre disputas terrestres e domínio sobre o mar pode ser mais bem compreendida a partir da maneira como Schmitt analisou a Batalha de Lepanto, de 1571. O enfrentamento entre uma coligação de reinos europeus e o Império otomano pelo controle marítimo do Mediterrâneo confere uma dimensão relacional entre terra e mar no campo bélico, já que, em Lepanto “ contendieron ... las armadas de España y Venecia con la turca y alcanzaron la mayor victoria naval que han ganado los cristianos a los musulmanes. (...) Tropas de elite de la infantería española, los célebres Tercios, se batieron con los jenízaros, la tropa de elite del Imperio turco, en un combate cuerpo a cuerpo sobre las cubiertas de las naves ${ }^{164 . "}$

A Batalha de Lepanto envolveu, no lado cristão, a chamada Liga Santa, composta por Espanha, Veneza, Malta e os Estados Pontifícios. O grande número de países europeus envolvidos em um enfrentamento que representou o fim da soberania otomana no Mediterrâneo mostra que grande parte da Europa, inclusive o Papado, havia escolhido o mar como elemento de espaço de poder e possessão, estendendo as disputas territoriais europeias para o mar próximo. Assim, o controle do Mediterrâneo transformava-se em fonte de autoridade geopolítica, conferindo ao "espaço territorial" uma redefinição conceitual em direção aos mares.

Por mais que Portugal tivesse chegado às Índias e liderasse grande parte dos feitos navais a partir do século XV, a estratégia portuguesa não privilegiava a aventura marítima isolada da dominação territorial, uma vez que os portugueses chegaram à Ásia por meio de uma navegação costeira ao longo da África. Já os espanhóis, que enfrentaram mais diretamente as vicissitudes da navegação marítima aberta, deram preferência à conquista de espaços coloniais nas Américas, sendo superados no campo náutico pelos ingleses nos séculos seguintes. Para Schmitt, o século XVI ainda era o período em que a transposição da existência humana se transferia da terra para o mar, não separando muito claramente o modo "territorial" com que as disputas de poder e conquista se davam na Europa. Apenas quando a Inglaterra assume a liderança política do mundo é que esse poder passa a ser medido pelo senhorio inglês sobre os mares, fundamentalmente, o que somente ocorre a partir do século XVIII.

Entretanto, o argumento de Carl Schmitt sobre o domínio espacial europeu a partir do século XVI, à revelia das oportunas informações técnicas sobre a construção naval e a formação de potências marítimas na Europa, perde fôlego ao tentar justificar,

\footnotetext{
${ }^{164}$ Ibidem, p. 32.
} 
de maneira insistente, a supremacia inglesa no campo naval. A base do argumento do autor é a de que os reinos católicos europeus privilegiaram o controle do espaço terrestre, enquanto os protestantes se dispuseram ao domínio marítimo mundial com maior vigor. Esse raciocínio fica mais evidente quando Schmitt analisa a formação imperial francesa, em oposição à da Inglaterra. A França não teria dado continuidade a iniciativas marítimas conduzidas, sobretudo, por protestantes huguenotes. Ao se "romanizar", o Império francês optou pela via tradicional do poder terrestre, que, para Schmitt, marcou o catolicismo ${ }^{165}$.

Uma conclusão possível ao argumento de Schmitt é que, ao querer traçar um percurso histórico para a supremacia marítima dos ingleses a partir do século XVIII, o autor olha para o século XVI e XVII a partir da ordem política internacional construída na Europa ao longo do século XVIII, quando a Paz de Utrecht, em 1713, garantiu a vitória política e jurídica das potências protestantes, principalmente da Inglaterra, em relação ao domínio marítimo católico espanhol. Nas palavras do autor:

"Sólo Inglaterra logró dar el paso que la llevaría de una existencia medieval terrestre y feudal a una existencia puramente marítima que mantendría en equilibrio a todo el mundo terrestre. España conservó su carácter demasiado terrestre y no pudo sostenerse, a pesar de su imperio de Ultramar, como potencia marítima. (...) Inglaterra, en cambio, no estaba complicada tan profundamente en la política y las guerras del continente europeo como estos rivales suyos, y era, segundo señala John Robert Seeley 'the least hampered by the old world', realizando asi la transición hacia el lado marítimo del globo terráqueo $y$ determinando el nomos de la tierra desde el mar. ${ }^{166,}$

Schmitt pensa o século XVI exclusivamente a partir das relações intra-europeias, e, por isso, não se preocupa em identificar na sua descrição dos anos quinhentistas uma definição clara e ampla de Renascimento, ainda que, por sua opção interpretativa "europeia", fique implícita uma concepção de Renascimento definida pelas contribuições exclusivas dos países da Europa ocidental. Assim, mais do que um período "renascentista", para Schmitt, o século XVI é o nascimento do "mundo do mar aberto", em que o espaço é determinado mais pela disputa do que pela negociação simbiótica.

Se, por um lado, o Mar Mediterrâneo contribuiu para a definição do conceito de espaço durante o século XVI, principalmente pela ideia de conflito, por outro, a África

\footnotetext{
165 "Francia no perseveró en su primer impulso marinero, unido, por otra parte, al protestantismo hugonote, ya que su tradición cultural se movía en la línea romana, y cuando con la noche de San Bartolomé (1572) y la conversión de Enrique IV se decidió por el catolicismo y contra los hugonotes, se decidía también, es decir, optaba en última instancia por la tierra y contra el mar." Idem, p. 47.

${ }^{166}$ Carl Schmitt. El nomos de la tierra en el derecho de gentes del "Jus publicum europaeum". Madri: Centro de Estudios Constitucionales, 1979. p. 203.
} 
teve papel de extrema relevância ao permitir que a opção pela negociação cultural, própria do Renascimento, fosse também parte do conceito de espaço nesse período. Para melhor compreender essa relação entre a visão renascentista sobre a África e sua contribuição ao conceito de espaço no período das grandes navegações, cabe destacar como europeus e árabes nomeavam o território africano.

A Europa convencionou chamar de "África" no século XVI, um conjunto de territórios ao sul do Mar Mediterrâneo que coincidiam com a antiga província romana da Africa Proconsularis, criada em 146 a.C, e seus arredores (antigas províncias de Mauretania Tingitana, Mauretania Cesariense, e Cyrenaica et Creta). Conforme já visto neste trabalho, a região era disputada por cristãos e muçulmanos na Era Moderna, refletindo uma complexidade de sociedades e culturas integrada por grupos distintos como povos nômades, centros urbanos e comerciais islamizados, e enclaves cristãos europeus.

Enquanto a definição cristã e europeia de "África" remontava à tradição romana, os árabes islamizados definiam o sul do Mediterrâneo por conceitos próprios, consolidados em um vocábulo árabe com duas origens possíveis: Ifriquiyy (أفريقية). De acordo com João Leão Africano:

"L'Africa nella lingua arabica è appellata Ifrichia, da faraca, verbo che nella favella degli Arabi suona quanto nella italiana "divide", e perché ella sia così detta sono due opinioni. L'una delle quali è percioché questa parte della terra è separata dalla Europa per il mar Mediterraneo e dall'Asia per il fiume del Nilo; l'altra è che questo tal nome sie derivato da Ifrico, re dell'Arabia Felice, il quale fu il primo che venisse ad abitarla. Costui, rotto in battaglia e scacciato dai re d'Assiria, non potendo far ritorno al suo regno col suo esercito velocemente passò il Nilo, e avendo dirizzato il cammino verso ponente, non si fermò prima che nelle parti vicine a Cartagine pervenne. E di qui è che gli Arabi non tengono quasi per Africa altro che la regione di Cartagine, e per tutta Africa comprendono la parte occidentale solamente. ${ }^{167,}$

As fronteiras físicas da África quinhentista em relação ao mundo renascentista eram bem delimitadas pelo Mediterrâneo, mas culturalmente mostravam-se mais porosas pela maneira como as disputas terrestres intra-europeias e entre europeus cristãos e povos muçulmanos eram vividas em sua costa mediterrânea. Ao tratar de

\footnotetext{
167 "A África é chamada em língua árabe de Ifriquiyya, do verbo faraca que, na linguagem falada dos árabes, significa "partida" ou "dividida". Existem duas opiniões sobre essa denominação, uma delas leva em consideração que essa parte da terra está separada da Europa pelo Mar Mediterrâneo e da Ásia pelo rio Nilo. E a outra opinião é que esse nome vem de "Ifrico", rei da Arábia Feliz, que foi o primeiro que chegou a habitá-la. Ao ser derrotado em batalha, esse rei foi expulso pelos assírios, e não podendo voltar com seu exército para seu reino, atravessou rapidamente o Nilo e, conduzindo seus passos em direção ao poente, não parou até chegar aos arredores de Cartago. A partir disso é que se explica porque os árabes entendam por África apenas a região de Cartago, enquanto que à sua totalidade tomam somente pela parte ocidental (Magreb)."
} 
locais de cultura e determinação de fronteiras, Homi K. Bhabha reforça a necessidade de se encontrarem na experiência humana moderna os processos determinados por situações de diferenças culturais.

A concepção de espaço moderno, quando tomada pela experiência histórica da África no século XVI, mostra que, o ambiente de disputa vivido pelo Mar Mediterrâneo nesse momento é redefinido pela condição africana de "local de distinções culturais". Mesmo que para cristãos e muçulmanos a África como espaço a ser dominado seja definida conceitualmente por tradições particulares (como o Império Romano ou um reino da Arábia Feliz), ela se transforma pela articulação social da diferença em uma espécie de "entre-lugar", em que a disputa e a necessidade de conflito se fundem a um processo de negociação cultural complexo. Desse modo, a África do século XVI pode ter diversas definições, e, entre elas, o sentido de "interstício": espaço entre o conflito e a negociação, entre o antagonismo e a afiliação ${ }^{168}$.

A África passou a ser considerada um espaço cobiçado pelos reinos, repúblicas e impérios que, ordenados juridicamente, manifestaram o desejo pelo domínio territorial no continente europeu, pelo controle naval do Mediterrâneo, e pela conquista das terras e das almas nas grandes navegações. A afirmação do papel político desses grandes órgãos jurídicos fez da África do século XVI um lugar de ação performativa, o que permitiu que os rincões africanos fossem explorados e definidos por homens modernos que se encaixavam em situações de "espaço de interstício", como os viajantes.

Por essa razão, o percurso de vida de um narrador de viagens como o já citado João Leão Africano pode ser tomado como expressão concreta de um homem moderno voltado para o mundo, transpondo suas fronteiras territoriais e individuais em um espaço de interstício como a África. A descrição dos "limites" e da "população africana", que confere caráter performativo ao interstício e à distinção cultural, realizase na própria trajetória do viajante, que depende do embate e da negociação entre culturas para situar-se em sua própria época.

Ao final, a África como espaço de interstício deve ser caracterizada pela visão das culturas em interação na trajetória de sobrevivência de Leão Africano. Tanto o

\footnotetext{
168 "O que é teoricamente inovador e politicamente crucial é a necessidade de passar além das narrativas de subjetividades originárias e iniciais e focalizar aqueles momentos ou processos que são produzidos na articulação de diferenças culturais. Esses 'entre-lugares' fornecem o terreno para a elaboração de estratégias de subjetivação - singular ou coletiva - que dão início a novos signos de identidade e postos inovadores de colaboração e contestação, no ato de definir a própria ideia de sociedade. É na emergência do interstício - a sobreposição e o deslocamento de domínios da diferença - que as experiências intersubjetivas e coletivas de nação (nationess), o interesse comunitário ou o valor cultural são negociados.” Homi K. Bhabha. O local da cultura. Belo Horizonte: Editora UFMG, 2010. p. 20.
} 
mundo europeu quanto o mundo islâmico clássico compartilhavam olhares próprios para espaços de inevitável interação, ressaltando que de alguma maneira, o mundo inteiro os pertence. Sanjay Subrahmanyam, ao tratar da escrita de uma "história mundial" na modernidade, ressalta que em diversas culturas, inclusive não-ocidentais, a pretensão histórica de se representar toda a história do mundo era uma realidade. Para esse autor, no mesmo período em que Felipe II fez uso do lema Non sufficit orbis (o mundo não é o suficiente), imperadores muçulmanos como os da dinastia Mogul na Índia se atribuíam títulos de honra que exaltavam a condição de "imperadores do mundo $^{169}$ ". Dessa maneira, o domínio sobre o Mar Mediterrâneo e sobre a África passa a ser visto como uma questão importante para as duas matrizes culturais que Leão Africano negocia. Para relativizar sua condição de porta-voz do espaço de interstício, o viajante granadino transformou o interesse comercial que a África suscitava em argumento para a exploração desse espaço, transpondo aos territórios africanos um fenômeno moderno de grande êxito nas Américas e, em parte, da Ásia: a colonialidade.

\section{3 Às lágrimas: a questão da colonialidade e o espaço do interstício}

A dicotomia entre terra e mar e entre reinos católicos e protestantes não se limita às discussões sobre o domínio espacial euro-mediterrâneo, mas se reforça nas considerações de muitos intelectuais sobre o desenvolvimento econômico da Europa e do sistema capitalista. A autonomia da razão, que pode ser entendida como uma das múltiplas partes que caracterizam a modernidade, apresenta-se como um dos principais fatores que relacionam elementos culturais, econômicos, políticos e sociais da Europa do século XVI, tais como a estética renascentista, o capitalismo e a dessacralização do pensamento. A questão mais intrigante por trás da valorização dos aspectos racionais e

\footnotetext{
169 "We may begin with some examples of typical situations of the sixteenth century. On 10 December 1574, having received news of military reverses in both the Netherlands and the Mediterranean, as well as rumors of an impending tax revolt in Castile, the Habsburg ruler Philip II wrote to his secretary Mateo Vazquez, 'If this is not the end of the world, I think we must be very close to it; and, please God, let it be the end of the whole world, and not just the end of Christendom.' These gloomy, politic, and rather bloody-minded words of that Most Catholic Monarch show clearly enough that some humans in the late sixteenth century, at least, had little difficulty in moving from the scale of a kingdom such as Castile, to that of Spain, to that of an empire, to that of Christendom, and eventually to that of 'the whole world.' Philip II, like his father Charles V, used the words 'Castile, 'Spain' (usually in the sense of Iberia), and 'the Empire,' but he also famously made use in the 1580s of the Latin legend Non sufficit orbis (The world is not enough) to denote the extent of his ambitions. He was not alone in this, for in the seventeenth century, three successive Mughal emperors in India used titles such as Jahangir (World-Seizer), Shahjahan (World-Emperor), and "Alamgir (World-Seizer) to denote that the world barely sufficed for them either." Sanjay Subrahmanyam. On World Historians in the Sixteenth Century," Representations 91 (2005): 26-57.
} 
humanos da modernidade é que, para explicar as relações de poder na era da secularização, alguns estudiosos recorrem ao já citado binômio religioso "católicoprotestante".

Um exemplo da importância dessa chave interpretativa binomial é a maneira como H.R. Trevor-Roper periodiza a História da Europa entre fins do século XV e do século XVIII. Na perspectiva desse autor o Renascimento e o Iluminismo são os polos de um período em que o homem europeu experimentou o "progresso" de modo processual, e que pode ser dividido em duas fases longas e uma intermediária: a) a idade da Renascença europeia, entre 1500 e 1620; b) a fase da "revolução", entre 1620 e 1660; c) a idade do Iluminismo, entre 1660 e $1800^{170}$. Nessa lógica, o que diferenciava as duas longas idades era, para Trevor-Roper, o fato de que a Renascença teve como espaço de manifestação as regiões católicas (Itália e Espanha), enquanto o Iluminismo foi um fenômeno quase totalmente protestante (liderado pela Inglaterra, Holanda, e com a França transitando entre as duas confissões). No centro desse argumento está a ideia de que, ao longo do tempo, a Europa teria vivido um deslocamento de seu centro dinâmico, com a ascensão das sociedades protestantes e o declínio do mundo católico.

A valorização de aspectos religiosos sobre o progresso econômico e intelectual do homem moderno não é uma inovação interpretativa trazida por Trevor-Roper. O autor de Religião, reforma e transformação social é depositário de uma tradição acadêmica que possui as figuras de Max Weber e Werner Sombart como principais expoentes, o que o próprio Trevor-Roper atesta nessa mesma obra. Em poucas palavras, considera-se que Weber estabelece uma relação entre Reforma Protestante e avanço do capitalismo na Europa mediada por uma ética de organização racional do trabalho presente, sobretudo, na ideia de predestinação e êxito material do calvinismo ${ }^{171}$. Já Sombart acredita que a raiz do capitalismo moderno está nas mãos dos judeus sefaraditas do século XVI expulsos da Península Ibérica em direção ao norte da Europa $^{172}$.

\footnotetext{
170 "Se quisermos caracterizar brevemente todo este período, poderemos dizer que o primeiro grande período, os 120 anos compreendidos entre 1500 e 1620, foi a idade da Renascença europeia, uma época em que a liderança econômica e intelectual da Europa provém ou parece provir do Sul de Itália e Espanha; o período de 1620-60 pode ser descrito como o da revolução; e o segundo grande período, o que vai de 1660 a 1800, seria a idade do Iluminismo, época em que as grandes realizações da Renascença foram reatadas e elevadas a novos píncaros, mas a partir de novas bases." H.R. Trevor-Roper. Religiao, reforma e transformaçao social. Lisboa: Presença, 1972. p. 13.

${ }^{171}$ Ver: Max Weber. A Ética protestante e o espirito do capitalismo.

${ }^{172}$ Ver: Werner Sombart. Die Juden und das Wirtschaftsleben.
} 
As críticas à ênfase na dimensão religiosa como principal elemento constitutivo da modernidade se fundamentam em distintos aspectos. Pode-se afirmar que o foco nas sociedades protestantes dissimula o desenvolvimento significativo do capitalismo em outras regiões majoritariamente católicas, como as cidades italianas de Gênova, Veneza e Florença no século XVI, a França do século XVII, entre outros. Mas, dois pontos específicos são fundamentais para uma nova crítica das explicações que estimam aspectos religiosos do desenvolvimento do capitalismo e da modernidade: o eurocentrismo da perspectiva binomial católico-protestante, e a subestimação da violência como parte característica da modernidade.

O debate sobre as diferentes maneiras com que os intelectuais definem o espaço de atuação do Renascimento serve como exemplo do fato de que a modernidade produz um domínio europeu sobre a temporalidade. Enquanto se discutia se o Renascimento era uma experiência italiana, flamenca, francesa ou mesmo de outra região desse continente, reforçava-se a condição "europeia" das transformações culturais do século $\mathrm{XVI}^{173}$. Toda a epistemologia construída após o Renascimento alimenta, principalmente a partir do século XVIII, uma relação entre conhecimento e ciência moderna que fundamenta valores universais moldados pela racionalidade euro-atlântica. O papel da África, da Ásia e da América Latina na produção do conhecimento sempre esteve subordinado à crença incondicional de que as formas de saber de certa porção do mundo eram superiores às demais, estabelecendo-se uma relação vertical entre conhecimentos.

O princípio da existência de uma dominação epistemológica no tocante às reflexões sobre a modernidade fica mais evidente ao se retomar a discussão referente aos aspectos religiosos das transformações culturais e econômicas do século XVI. O binômio "católico-protestante" contempla o mesmo debate espacial que marcou o conceito de Renascimento na historiografia: a qual "Europa” pertence a modernidade? Seja qual for a resposta a essa pergunta, deve-se considerar o efeito assimétrico de poder presente nas conclusões de que a modernidade pertence aos europeus. Ao discutir o papel do eurocentrismo no processo de naturalização do conhecimento na modernidade, o sociólogo Anibal Quijano afirma que:

"O eurocentrismo não é exclusivamente, portanto, a perspectiva cognitiva dos europeus, ou apenas dos dominantes do capitalismo mundial, mas também do conjunto dos educados sob a sua hegemonia. E

\footnotetext{
${ }^{173}$ Para essa discussão, ver o capítulo 1 desta tese.
} 
embora isso implique um componente etnocêntrico, este não se explica, nem é a sua fonte principal de sentido $^{174 \%}$.

O que se mostra relevante nessa revisão epistemológica do lugar da Europa na construção da modernidade é a inclusão de visões não-europeias para se pensar o século XVI. Não se trata de uma separação drástica entre conhecimentos e visões de mundo distintas ou mesmo uma recusa absoluta a esse padrão, mas apenas a aceitação de que a história mediterrânea do século XVI possui outros atores, espaços e dinâmicas culturais que não limitam esse período ao pioneirismo europeu sobre as novas formas de se pensar o mundo. Não cabe à análise crítica sobre a condição eurocêntrica do debate a respeito do Renascimento e do século XVI colocar-se como uma acusação sobre a hegemonia euro-atlântica nas formas de conhecimento da ciência moderna. Ao invés do conteúdo eminentemente denunciativo, deve haver maior espaço para o teor reflexivo e diverso da experiência humana na modernidade, constituindo-se novos espaços de enunciação teórica como a África, a Ásia e a América Latina.

O maior problema da manifestação dessa epistemologia dominante sobre o século XVI é a tentativa de se remover grande parte dos aspectos moralmente depreciativos da formação do mundo moderno. Nesse sentido, nas apropriações sobre a quem pertence o mito da modernidade ignora-se a face mais reprovável dessa experiência: a violência do projeto colonizador. Em suas reflexões sobre o advento do mundo moderno Nelson Maldonado-Torres fomenta a posição crítica ao afirmar:

“o que o conceito de modernidade faz é esconder, de forma engenhosa, a importância que a espacialidade tem para a produção deste discurso. É por isso que, na maioria das vezes, aqueles que adoptam (sic) o discurso da modernidade tendem a adotar uma perspectiva universalista que elimina a importância da localização geopolítica. Para muitos, a fuga ao legado da colonização e da dependência é facultada pela modernidade, como se a modernidade como tal não tivesse estado intrinsecamente associada à experiência colonial ${ }^{175,}$.

As relações geopolíticas são decisivas para a construção de qualquer discurso de autoridade epistemológica sobre a modernidade. É preciso considerar que a exploração colonial foi expressão direta do projeto imperial que fez com que diferentes regiões da Europa concorressem entre si pela supremacia econômica, cultural e espacial do mundo que se expandia para além dos territórios europeus. Desse modo, ao mesmo tempo que é

\footnotetext{
${ }^{174}$ Anibal Quijano. Colonialidade de poder e classificaçao social. (IN) Boaventura de Sousa Santos e Maria Paula Meneses (orgs.). Epistemologias do Sul. São Paulo: Cortez editora, 2010. p. 85.

${ }^{175}$ Nelson Maldonado-Torres. A topologia do ser e a geopolítica do conhecimento. Modernidade, império e colonialidade. (IN). Boaventura de Sousa Santos e Maria Paula Meneses (orgs.). Epistemologias do Sul. São Paulo: Cortez editora, 2010. p. 411.
} 
fácil identificar essa relação entre modernidade e experiência colonial na dominação espanhola e portuguesa da América a partir do século XVI, ela também pode ser encontrada em outros atores europeus que não privilegiaram o Atlântico como espaço imperial direto, como é o caso das potências comerciais da Península Itálica, como Gênova, Veneza, Florença, e até mesmo o Papado.

O que se pretende explicitar com a análise da obra de Leão Africano é a existência de um projeto colonial liderado pelo Papa Leão X para a exploração comercial das potencialidades das terras africanas, e a obra Della descrittione dell'Africa et delle cose notabli che ivi sono é expressão desse projeto. Se a lógica de dominação e violência coloniais é parte constitutiva da modernidade no século XVI, essa lógica não pode estar restrita aos empreendimentos marítimos bem-sucedidos das coroas espanhola e portuguesa no Atlântico, mas se revela também no interesse que o Papado demonstra pelas "coisas notáveis" que Leão Africano ressalta em sua descrição da África. Mesmo após a morte do Papa Leão X, em 1521, essa constatação estende a relação entre violência colonial e projeto imperial a toda a modernidade do século XVI, sem as prerrogativas nacionais e religiosas que conferem supremacia a determinados povos europeus no interior da formação epistemológica do mundo moderno.

O enfoque na dimensão violenta da modernidade levou Walter Mignolo a discutir a existência de um "lado obscuro do Renascimento"176:

"la idea del lado oscuro del Renacimiento transciende los límites de la distinción que comúnmente se establece entre el Renacimiento y el periodo moderno temprano. Mientras que el concepto de Renacimiento se refiere al resurgimiento de los legados clásicos y a la constitución de la erudición humanística para la emancipación humana y el de periodo moderno temprano enfatiza la emergencia de una genealogía que anuncia el periodo moderno y posmoderno, el concepto del lado más oscuro del Renacimiento subraya la renovación de la tradición clásica como una justificación de la expansión colonial... ${ }^{177, "}$.

Por essa razão, uma das definições de Mignolo para a modernidade é a consolidação dos impérios coloniais europeus e suas implicações, o que retira o caráter exclusivamente apolítico e dominador da erudição humanística e da retomada da tradição clássica no Renascimento.

\footnotetext{
${ }^{176}$ Essa questão aparece diretamente referenciada em pelo menos dois trabalhos desse autor: 1) Walter D. Mignolo. The Darker Side of Renaissance: Literacy, Territoriality \& Colonization. Michigan, University of Michigan Press, 2006. 2a. Ediçao.; e 2) Walter D. Mignolo. "El lado más oscuro del Renacimiento", Universitas Humanística, No. 67. (janeiro-junho 2009).

${ }^{177}$ Walter Mignolo, 2009, p. 167.
} 
A proposta de Mignolo pretende dar voz às contribuições latino-americanas e indígenas à história universal pela revisão teórica dos estudos pós-coloniais. Esse caminho interpretativo almeja superar a narrativa estrutural da colonização a partir do século XVI, não limitando a análise do período colonial ao funcionamento da dominação linguística, mnemônica e espacial do poder europeu sobre as Américas. Para isso, Mignolo se debruça sobre as transformações semióticas que a experiência colonial trouxe tanto para europeus quanto para indígenas, e fundamenta sua discussão pela definição de conceitos como "discurso colonial" e "semiosis colonial".

Em relação ao primeiro desses conceitos, Mignolo invoca Peter Hulme para ressaltar que o “... discurso colonial pone la producción discursiva colonial en un contexto de interacciones conflictivas, de apropriaciones y resistencias, de poder $y$ dominación. ${ }^{178}$. Não cabe aqui discutir de maneira aprofundada as variações do conceito de discurso colonial na tradição acadêmica recente. Autores como Edward Said e Homi K. Bhabha se juntam a Mignolo como leitores de Frantz Fanon no debate sobre a função dominadora de discursos disciplinares que tratam de diferenças culturais. De todo modo, o que Mignolo propõe é ampliar o contexto das descrições sobre o "outro" em que o discurso colonial é apenas uma parte do campo de estudos composto por narrativas de homens que exercem o papel de colonizadores, operando as diversas linguagens produzidas pelas interações conflituosas entre povos distintos a partir do século XVI.

Como resultado do interesse por novos objetos culturais e assimetrias de poder que não se encerram na noção de "discurso colonial", Mignolo sugere o uso do conceito de "semiosis colonial", definido como:

“... un contexto más amplio de descripción del cual el discurso colonial es un componente importante. Se propone semiosis colonial con la intención de remodelar las fronteras de un campo de estudios principalmente habitado por textos escritos por los colonizadores, alfabéticamente o en sus lenguas, con el objeto de abrirlos a un espectro más amplio de interacciones semióticas en lenguas indígenas y en escrituras no alfabéticas ${ }^{179,}$.

O foco das ideias de Mignolo é a experiência colonial europeia na América Latina, sobretudo a espanhola. Entretanto, seu cuidado com a análise das influências culturais mútuas, entre povos inseridos na lógica colonial, não se limita ao contexto americano. As diferentes linguagens, signos e percepções que as relações humanas

\footnotetext{
${ }^{178}$ Idem, p. 178.

${ }^{179}$ Idem, p. 181.
} 
estabelecem e interpretam se estendem a qualquer cenário colonial, o que torna a aplicação da lógica da semiosis colonial possível, por exemplo, ao contexto de negociação e conflito cultural entre Islã, Cristandade e África que deu origem a obra Della descrittione dell'Africa et delle cose notabli che ivi sono.

Nos cenários de coexistência de culturas em condição assimétrica de poder, como a África descrita por Leão Africano, a análise imagética da semiosis colonial permite o distanciamento crítico da epistemologia dominante e favorece uma aproximação a práticas semióticas que revelam as camadas de significado das palavras e imagens usadas para descrever e avaliar culturas alheias. Por essa razão, a semiosis colonial se aplica a ambientes históricos em que se relacionam mais de uma tradição cultural, exigindo a aplicação de uma hermenêutica, chamada por Mignolo de “pluritópica ${ }^{180 " . ~ A ~ i n t e r p r e t a c ̧ a ̃ o ~ e ~ c o m p r e e n s a ̃ o ~ d e ~ s i t u a c ̧ o ̃ e s ~ h i s t o ́ r i c a s ~ p e r m e a d a s ~ p o r ~}$ diferenças culturais reivindica uma dimensão ética do conhecimento que deve defender a coexistência de perspectivas, mesmo em meio a relações de poder e de violência.

Em nome dessa nova maneira de se analisarem as relações coloniais, Aníbal Quijano sugere a substituição do termo "colonialismo" pelo conceito de "colonialidade", definido por ele como:

"Colonialidade é um conceito diferente de, ainda que vinculado a, Colonialismo. Este último refere-se estritamente a uma estrutura de dominação/exploração onde o controle da autoridade política, dos recursos de produção e do trabalho de uma população determinada domina outra de diferente identidade e cujas sedes centrais estão, além disso, localizadas noutra jurisdição territorial. Mas nem sempre, nem necessariamente, implica relações racistas de poder."

Quijano define o termo colonialidade a partir de seu interesse pela denúncia de qualquer classificação social/étnica imposta pelo padrão de poder colonial criador da ideia de raça. Dessa maneira, o autor discorre sobre um conceito de "colonialidade de poder", entendido como um novo modelo de pretensa superioridade e exploração do outro por meio da articulação entre raça e o crescimento do capitalismo elaborada pelos impérios europeus na modernidade.

Outras formas de definição do conceito de colonialidade surgem a partir das reflexões de Quijano, principalmente quando Walter Mignolo e Nelson MaldonadoTorres defendem a existência de uma "colonialidade do saber": a ação da epistemologia

\footnotetext{
180 Walter Mignolo retira o conceito de "hermenêutica pluritópica" de Raimon Panikkar: "En contraposición a la comprensión monotópica de la hermenéutica filosófica, la semiosis colonial presupone más de una tradición y, por tanto, demanda una hermenéutica diatópica o pluritópica, un concepto que tomo en préstamo de Raimundo Panikkar”. Idem, p. 182.
} 
dominante a serviço da expansão colonial; e de uma "colonialidade do ser" que “... refere-se ao processo pelo qual o senso comum e a tradição são marcados por dinâmicas de poder de caráter preferencial: discriminam pessoas e tomam por alvo determinadas comunidades $^{181}$ \%. É justamente esse processo discriminatório estabelecido pela relação entre conhecimento e poder que elabora o conceito de ser no interior da experiência discursiva e da semiótica da colonização.

A presença da colonialidade na primeira parte da obra Della descrittione dell'Africa et delle cose notabli che ivi sono pode ser percebida em passagens que direta ou indiretamente constroem imagens de classificação cultural sobre os africanos nativos no interior da lógica colonizadora da modernidade do século XVI. Ao descrever as características gerais dos Sahid, uma linhagem de árabes que imigraram para o deserto da Líbia em tempos remotos, Leão Africano afirma:

\footnotetext{
"Sahid abitano similmente nei deserti di Libia; costoro sogliono tener domestichezza e conversazion nel regno di Guargala, hanno infiniti bestiami, e forniscono di carne tutte le città e luoghi che confinano coi loro diserti; ma ciò nel tempo della state, percioché il verno non si partono dal diserto. Sono di numero appresso centocinquantamila, ma pochi cavalli hanno. ${ }^{182,}$
}

O viajante constrói aqui uma imagem desse grupo marcada pela racionalidade colonial ao classificá-lo por aspectos estratégicos de dominação, como, por exemplo, o número de pessoas em relação ao número de cavalos. A caracterização de determinados povos africanos será erigida a partir dos interesses de dominação colonial e comercial, sugerindo que o número baixo de cavalos entre os Sahid os classifica tanto como pouco propensos à mobilidade comercial no deserto, quanto por seus poucos recursos militares de resistência colonial como a cavalaria.

Esse padrão de classificação étnica se repete em outras descrições sobre povos do deserto da Líbia, como os Etbegi que "sono cerca a centomila uomini da guerra, $e$ la metà è a cavallo" ${ }^{183 " ;}$ os Sumait que "sono intorno a ottantamila atti alla milizia, e la più parte a piè ${ }^{184 » ;}$ os Elmuntafic que "possono fare da ottomila cavalli molto bene in

\footnotetext{
${ }^{181}$ Nelson Maldonado-Torres. Op. cit. p. 423.

182 “Os Sahid habitam também o deserto da Líbia, e se desenvolvem com familiaridade no reino de Guargala. Possuem infinitos rebanhos e fornecem carne a todas as cidades e lugares próximos a seus desertos, mas isso ocorre, sobretudo, no verão. Durante o inverno, não saem de seus desertos. São aproximadamente cento e cinquenta mil, mas possuem poucos cavalos."

183 “... contam com quase cem mil guerreiros, metade a cavalo."

184 “.... há entre eles cerca de oitenta mil homens preparados para a vida militar, a maior parte a pé.”
} 
ordine $^{185 " ;}$ e os Sobaich que "son da quattromila cavalli bene e ottimamente in ordine $^{186,}$

Os povos de outras regiões da África também são classificados por esses valores, mas chama a atenção o fato de que esse tipo de descrição se repete com maior frequência entre os habitantes do deserto da Líbia. Apesar de ser um homem de ampla formação intelectual e de ter exercido a atividade de diplomata por muitos anos, Leão Africano não possui nenhuma formação militar específica que o qualifique como alguém capaz de produzir informações detalhadas sobre os aspectos guerreiros de certo povo. Há, portanto, um esforço feito pelo viajante para dar conta do que parece ser uma demanda daqueles que encomendaram o seu trabalho de espionagem. É claro que Leão Africano é um observador sensível à grande parte das questões que caracterizam os povos que conhece, mas o fato de sua obra ser uma missão supostamente sugerida pelo Papa como parte de uma artimanha para garantir sua sobrevivência na Península Itálica é um argumento de colonialidade de poder.

Entretanto, os aspectos militares de resistência e de conquista colonial não são os únicos elementos que servem para a classificação dos povos africanos. Quando relata os hábitos e o cotidiano dos nômades que vivem entre o Monte Atlas e o mar Mediterrâneo, Leão Africano revela mais elementos constitutivos desses que se encontram em condição subalterna no discurso de dominação:

\footnotetext{
"Sono eziandio più barberi quasi e vili di natura di quei del diserto, ma sono nondimeno liberali, e una parte di loro, la quale abita nel regno di Fez, è soggetta e tributaria del re.

Quegli che abitano d'intorno al regno di Marocco e in Duccala un tempo vissero liberi da ogni gravezza, insino a tanto che i Portogalesi ebbero dominio di Azafi e di Azemor: allora tra loro si sollevarono parti e domestiche discordie, per le quali il re di Fez una parte ne roinò e un'altra il re di Portogallo, senza che la carestia, che in questi anni fu in Africa, gli oppresse in modo che i miseri Arabi volontariamente andarono in Portogallo, offerendosi per ischiavi a chiunque desse loro nutrimento. ${ }^{187,}$
}

As palavras escolhidas inicialmente pelo viajante para descrevê-los são diretas: "bárbaros" e "autônomos" (ainda que seja apenas uma parte deles). Há aqui uma relação

\footnotetext{
185 “... podem dispor de cerca de oito mil cavalos bem treinados."

186 "Possuem em torno de quatro mil cavalos otimamente treinados."

187 "São por sua vez, mais bárbaros e naturalmente vis que a gente do deserto, mas são, não obstante, autônomos, ainda que uma parte deles, que vive no reino de Fez, está submetida ao pagamento de tributos a seu rei. Aqueles que habitam as cercanias do reino do Marrocos, e em Duccala, foram durante determinado tempo livres de tributos até que os portugueses dominassem Azafi e Azemor. Então, uma parte deles se rebelou e houve discórdias internas, fazendo com que o rei de Fez governasse em uma parte, e em outra o rei de Portugal. A carestia que se instalou nesse ano na África, os oprimiu de tal maneira que os miseráveis árabes da região voluntariamente foram para Portugal, oferecendo-se como escravos a qualquer que lhes desse comida".
} 
clara entre comércio, subordinação fiscal e autonomia do ser, já que os portugueses e o reino de Fez os submetem por meio da cobrança de tributos, e quem o faz domina o comércio na área. Isso é possível porque mesmo tendo experimentado certo momento de autonomia, essa população se sujeita naturalmente à condição subalterna por entregarem-se voluntariamente à qualidade de escravos em caso de miséria. $O$ argumento de justificativa para a dominação colonial não só está claro pela "escravização voluntária" como também se manifesta pela chancela da experiência portuguesa, um dos principais rivais comerciais das cidades italianas, principalmente da Florença dos Medicis.

Assim, a classificação étnica própria da colonialidade se efetiva na representação dos nativos que Leão Africano faz nessa passagem, posicionando-se de maneira integrada ao vínculo entre capitalismo comercial e dominação colonial inseparável da modernidade do século XVI. Todos os subsídios ao projeto colonizador do Papado encontram-se contemplados na exploração do Norte da África já feita pelas distintas forças comerciais que atuam na região: estrutura militar, comércio, transporte, classificação étnica e subalternidade.

Por fim, como parte do padrão de poder colonial reproduzido por Leão Africano em sua categorização dos povos nativos vê-se que se espelham no próprio vocabulário do viajante determinados conceitos que pertencem diretamente ao universo linguístico colonial da Europa do século XVI. Ao se referir aos antigos africanos e às presenças religiosas do judaísmo, do cristianismo e do Islã no continente, o viajante afirma:

“... solo quelli che erano giudei e da cristiani e da Africani furono totalmente distrutti. Quegli altri che abitano vicino al mare Oceano sono tutti gentili e adorano gli idoli, e questi hanno veduti, e ancora avuta qualche pratica con loro, molti Portogallesi.

Gli abitanti di Barberia rimasero essi ancora lungo tempo idolatri, e dugentocinquanta anni avanti il nascimento di Maumetto diventarono cristiani, percioché quella parte dove è Tunis e Tripoli fu dominata da certi signori pugliesi e siciliani, e la rivera di Cesaria e di Mauritania similmente fu signoreggiata da Gotti. $^{188,}$

A adequação da linguagem utilizada na descrição da África às imagens sobre o outro já consolidadas na Europa fica evidente pelo uso do termo "gentis", seguido de

\footnotetext{
188 "Somente os que eram judeus foram totalmente destruídos pelos cristãos e africanos. Aqueles que vivem próximos ao mar Oceano, são todos gentis e adoradores de ídolos; como visto por muitos portugueses que ainda mantêm relações com estes. Os habitantes da Berberia também se mantiveram idólatras por muito tempo e fizeram-se cristãos somente duzentos e cinquenta anos antes do nascimento de Maomé, razão pela qual, aquela parte onde é Tunis e Trípoli foi dominada por senhores da Puglia e da Sicilia, da mesma forma que a costa da Cesarea e da Mauritânia foi senhoreada pelos godos.”
} 
“idólatras". No vocabulário italiano e cristão do século XVI e XVII a palavra "gentili" (gentios) é definida como os povos que antes da vinda de Jesus Cristo adoravam ídolos ${ }^{189}$. Este é um conceito de época que se repete em muitos textos de colonizadores do período, e o uso desse vocábulo na obra de Leão Africano mostra o esforço do autor em adaptar-se aos signos mais facilmente identificados pelos seus leitores. Já o termo “ídolatras" e suas variações não pertencem exclusivamente ao universo cristão colonizador, mas também pode ser encontrado em textos pertencentes à tradição originária de Leão Africano: o Islã. São várias as suras do Alcorão ou os textos da teologia islâmica que apresentam e discutem a idolatria como contrária à fé legítima. Não cabe aqui enumerá-los, mas apenas mostrar que a imagem da idolatria atribuída comumente aos habitantes da África serve aos signos interpretativos que tanto a visão cristã quanto a islâmica sustentam nas suas principais formas de classificação dos povos.

Ao que parece, a África que Leão Africano tenta traduzir aos interesses coloniais das cidades italianas é uma velha conhecida dos senhores das Penínsulas Itálica e Ibérica. Por uma ironia do destino, os mesmos senhores da Apúlia e da Sicilia que aprisionaram o viajante granadino e o levaram para o cativeiro na corte papal são agora, personagens e, futuramente, leitores da sua maior obra.

\subsection{Escorre pelas mãos: África e a fluidez civilizacional - Umrān e trânsito cultural}

Como as águas de um rio, que se movem pelo seu curso natural em direção ao mar, as cidades italianas e o Norte da África dirigem-se no século XVI ao Mediterrâneo em um fluxo duplo e contínuo. As mercadorias, pessoas, palavras, usos, notícias e projetos formam um intenso trânsito cultural que transforma todas as coisas de modo surpreendente, arriscado e impreciso. Quem era diplomata na Península Ibérica, faz-se viajante no Mediterrâneo, transmuta-se em cativo na Sicília, se refaz como erudito em Roma, e se compõe como "africano", "cristão", "espião" ao sabor das marés revoltas da vida do homem moderno do século XVI. Mas há uma diferença entre fazer-se africano na Europa e ensinar aos europeus o que é a África. O entendimento que Leão Africano tem sobre o continente africano é baseado também no que o viajante foi antes de ser o

\footnotetext{
189 De acordo com o Vocabolario Degli Accademici Della Crusca:: “... si chiamavano que' popoli, che innanzi alla venuta di Giesucristo, adoravan gl' Idoli”.
} 
que lhe impuseram, já que a África de Leão Africano tem muitos traços de Nascido alHasan ibn Muhammad al-Wazzan al-Fasi.

Um dos aspectos mais perceptíveis da origem muçulmana na maneira que Leão Africano representa a África é como o autor de Della descrittione dell'Africa et delle cose notabli che ivi sono se revela como leitor contumaz de Ibn Khaldun, o mais renomado historiador da tradição cultural árabe-islâmica. De acordo com Oumelbanine Zhiri, a geografia descritiva de Leão Africano combina a observação direta a referências próprias da herança científica deixada pelos árabes, tanto que “c'est sans doute la première mention de ce dernier (Ibn Khaldun) dans um texte publié en Europe ${ }^{190}$. $\mathrm{O}$ foco da análise de Zhiri é a presença, em Leão Africano, do conceito de "decadência", desenvolvido por Ibn Khaldun. Essa aproximação entre os dois autores ficaria mais evidente na descrição que o viajante faz do reino de Fez e de questões ligadas ao ocultismo e ao misticismo registrado nessas terras. O problema é que restringir a influência de Ibn Khaldun a citações diretas ou à presença de um conceito específico na obra de Leão Africano é uma opção analítica que pode ser aprofundada. Para tanto, cabe considerar algumas características mais gerais do conhecimento sobre o mundo elaborado por Ibn Khaldun ${ }^{191}$.

Um primeiro elemento importante que aproxima os dois autores é a impossibilidade de separar o resultado final de seu trabalho intelectual, das vicissitudes pessoais sofridas ao longo do processo de elaboração de suas obras. Ambos encontram, na escrita e na reflexão sobre o mundo, o modo mais oportuno de negociar tanto suas inquietudes, quanto a própria sobrevivência. Sobre Ibn Khaldun, nas palavras de Beatriz Bissio: "do objetivo inicial, que era compreender os seus próprios fracassos, passou à meta mais ambiciosa de uma concepção global da história e da análise das estruturas sociais e políticas ${ }^{192,}$.

\footnotetext{
190 “... le texte est à l'évidence une œuvre de géographie descriptive, où l'observation directe s'associe aux citations allusives ou directes d'ouvrages divers; il s'inscrit dans des cadres épistémologiques hérités de la science arabe. (...) À lire la Cosmographia, il ne fait pas de doute que son auteur s'inscrit consciemment dans une tradition savante de langue arabe, composée de géographes et d'historiens, mais aussi de médecins et de poètes, et qu'il la convoque autant que le lui permet sa mémoire, puisque les textes en question lui sont inaccessibles au moment de la rédaction." Oumelbanine Zhiri. Lecteur d'Ibn Khaldûn: le drame de la décadence. (IN). François Pouillon et ali. Léon L'Africain. Paris: Karthala, 2009. pp. 212-213.

${ }^{191}$ Parte da biografia desse autor e algumas ideias sobre sua noção de História se encontram no primeiro capítulo dessa tese.

${ }^{192}$ Beatriz Bissio. O mundo falava árabe: a civilização árabe-islâmica clássica através da obra de Ibn Khaldun e Ibn Battuta. Rio de Janeiro: Civilizaçao Brasileira, 2012. p. 81.
} 
Mas, no interior dos elementos extraídos das ideias de Ibn Khaldun que estão presentes na interpretação sobre a África de Leão Africano, o ponto que mais merece destaque é o uso indireto do conceito de "Umrān" na obra Della descrittione dell'Africa et delle cose notabli che ivi sono ${ }^{193}$. Esse termo é difícil de ser diretamente traduzido para as línguas latinas, já que seu significado é mais complexo do que qualquer definição que lhe confira um sentido imediato. Richard Max de Araújo, por exemplo, o define como:

“... um conceito de base no pensamento khalduniano. Pode-se traduzi-lo por 'vida social', tomando social num senso bastante amplo: tudo o que cimenta a existência material, espiritual e intelectual de um determinado agrupamento humano. Além disso, o termo vem qualificado pela palavra baxari (humano), pois o umran no sentido de sociabilidade faz parte da natureza da espécie humana.

Trata, portanto, do sentimento e da necessidade dos homens viverem em sociedade, seja no deserto, na montanha, no campo ou na cidade. Isso porque os homens têm uma inclinação natural à vida em sociedade. ${ }^{194,}$

Desse modo, o conceito de "Umrān" anuncia um conjunto de significados que possuem a história como o principal lugar de manifestação ${ }^{195}$. Isso fica evidente quando autores árabes de séculos posteriores a Ibn Khaldun começam a recorrer ao termo "Umrān" para desenvolver seus argumentos sobre o mundo moderno. Sobre o impacto desse conceito nos escritos árabes posteriores, Beatriz Bissio ressalta que esse conceito “... começou a ser utilizada(o) de forma muito mais ampla já a partir dos séculos XV e XVI. Essa constatação indicaria uma influência das ideias khaldunianas na produção historiográfica em língua árabe ${ }^{196 "}$. E ainda que Leão Africano não seja um historiador por excelência e sequer escreva para os árabes, sua visão da África e dos africanos nativos corrobora o trânsito cultural mantido pelo conceito de "Umrān" no Mediterrâneo moderno.

A camada tênue das ideias de Ibn Khaldun na África de Leão Africano aparece, sobretudo, nas descrições que o viajante faz dos diversos aspectos da vida humana nesse continente, subordinadas ao ímpeto de classificação social, cultural e étnica intrínsecos ao seu vínculo com a colonialidade do projeto papal. Para tanto, Leão Africano recorre às duas categorias de "Umrān" construídas por Ibn Khaldun: a "Umrān al-badawi"

\footnotetext{
${ }^{193}$ É claro que outros conceitos importantes de Ibn Khaldun como a ideia de decadência dos Estados e a al-asabiyya (força tribal, espírito de parentesco) podem ser discutidos na obra de Leão Africano, mas, para a ideia de fluidez civilizacional do comércio no século XVI, essa tese focará no conceito de "Umrān" ${ }^{194}$ Richard Max de Araújo. Ibn Khaldun: a ideia de decadência dos Estados. Sao Paulo: Humanitas, 2007. pp. 69-70.

${ }^{195}$ Ver capítulo 1 desta tese.

${ }^{196}$ Beatriz Bissio. Op. Cit. p. 85.
} 
(عمران البدوي): a civilização “rural/beduína"; e a "Umrān al-hadari” (عمران الحضاري): a civilização "urbana/sedentária". Ambos os espaços civilizacionais possuem importância para a formação social do homem, mas Ibn Khaldun entende que a civilização rural/beduína é uma etapa de desenvolvimento da organização social humana que antecede uma forma mais aprimorada de vida representada pela civilização "urbana/sedentária".

Por essa razão, a sutileza da presença do conceito de "Umrān" na representação da África e de seus nativos em Leão Africano mostra-se na valorização que o viajante faz dos espaços urbanos de poder em oposição à vida nômade em áreas desérticas. No caso da Terra dos Negros:

"Sono questi regni discosti l'uno dall'altro, e dieci di loro sono o da qualche diserto dell'arena separati o dal fiume Niger. Ed è da sapere che anticamente ogni regno da per sé era posseduto da un signore, ma a' tempi nostri tutti i quindici regni sono sottoposti al dominio di tre re, cioè del re di Tombutto, e questo ne possede la maggior parte, del re di Borno, il quale ne ha la minore, e l'altra parte è in potere del re di Gaogà. Egli è vero che 'l signore di Duccala ve ne tiene pure un piccolo stato. Confinano con questi regni dalla parte di mezzogiorno molti altri regni, cioè Bito, Temiam, Dauma, Medra, Gorhan; e di loro i signori e gli abitanti sono ricchi e assai pratichi, amministrano giustizia e vi tengono buon governo. Gli altri sono di peggior condizione che le bestie ${ }^{197}$."

Nos reinos já organizados e civilizados de forma urbana/sedentária, não somente o governo e a justiça estão consolidados, como a riqueza material (trazida possivelmente pela fluidez comercial) faz seus habitantes serem identificados como "práticos". Os desertos de areia são retratados como fronteiras físicas dos reinos organizados, e, enquanto espaços da civilização nômade/sedentária, não são descritos como áreas de organização "prática" da vida humana, já que seus habitantes sequer são mencionados nesse trecho da obra.

Desse modo, a África é o lugar onde os estágios distintos da vida civilizacional convivem, mantendo-se por meio do nomadismo uma condição social diferente e, portanto, colonizável. Mas, de acordo com Leão Africano, existem reinos da Terra dos Negros que se caracterizam pela bestialidade em que se encontram. Não há muita

\footnotetext{
197 "Estes reinos estão separados uns dos outros por um deserto de areia, ou então pelo rio Níger. E sabendo que outrora, cada um dos ditos reinos eram possessões de um único senhor, hoje, os quinze reinos estão submetidos ao domínio de três reis: o de Tombutto, e este possui a maior parte; o rei de Borno, dono da menor, enquanto que a terceira está em poder do rei de Gaoga. De fato, o senhor de Duccala domina também um estado pequeno. Limitam-se com estes reinos à a meio-dia, muitos outros, que são os de Bito, Temiam, Dauma, Medra, Goran: cujos senhores e habitantes são ricos e assaz práticos, administram a justiça e se governam bem, enquanto que os outros são de pior condição que as bestas."
} 
informação sobre essas terras nesse trecho, porém, o fato de existirem reinos com distintas formas de organização civilizacional reforça o olhar classificatório do viajante, o que reafirma o caráter de colonialidade de suas descrições sobre a África do século XVI.

Um ponto que embasa o argumento de distintos graus de organização da vida humana entre os africanos é a análise de sua história e ocupação territorial. A origem dos habitantes da África e a forma como se comunicam se transformam em objeto do diagnóstico que Leão Africano faz dos nativos, levando em consideração padrões culturais sensíveis às expectativas dos leitores europeus. Parte da astúcia do viajante é justamente estar atento às representações atraentes aos homens para quem esse material é destinado. O trânsito cultural promovido pelo trabalho descritivo de Leão Africano faz da África e de seus nativos os veículos de negociação simbólica da própria legitimidade social do autor em um universo estranho como a corte papal da primeira metade do século XVI.

\section{Com relação aos primórdios da África, Leão Africano afiança:}

"Dicono i cosmografi e gli scrittori delle istorie l'Africa anticamente esser stata per ogni sua parte disabitata fuori che la terra negra, e hassi per cosa certa che la Barberia e la Numidia è stata priva d'abitatori molti secoli. Quelli che vi abitano, cioè bianchi, sono appellati el barbar, nome derivato, secondo che alcuni dicono, da barbara, verbo che nella lingua loro tanto significa quanto nella italiana "mormorare". Percioché la favella degli Africani tale è appresso gli Arabi quali sono le voci degli animali, che niuno accento formano eccetto il grido. Alcuni altri vogliono che barbar sia nome replicato, percioché bar nel linguaggio arabico dinota diserto. E dicono che ne' tempi che 'l re Africo fu rotto dagli Assirii, o come si fosse dagli Etiopi, egli fuggendo verso Egitto e tuttavia essendo seguitato da' nimici, non sapendo come difendersi chiedeva alle sue genti che lo consigliassero qual partito potesse prendere per la salute loro. Al quale essi altra risposta non davano se non gridando: "el bar bar", cioè "al diserto, al diserto", volendo inferire che per loro non si conosceva altro rimedio fuori che passando il Nilo ridursi nel diserto di Africa. E questa ragione è conforme con quelli che affermano la origine degli Africani procedere dai popoli dell'Arabia Felice. ${ }^{198,}$

\footnotetext{
198 Às palavras dos cosmógrafos e escritores da história, a África estava antigamente desabitada por toda parte, menos a Terra dos Negros. Dá-se por coisa certa que a Berberia e a Numidia estiveram privadas de população por muitos séculos. Os que hoje as habitam, sendo brancos, são chamados de Barbar, nome derivado, segundo dizem alguns, de barbara, que em sua própria língua significa, como em italiano "murmurar": ocorre portanto que a fala dos africanos é para os árabes como a fala dos animais, que de nenhum sotaque é composto, senão de gritos. Outros dizem que Barbar é uma palavra repetida, já que bar na linguagem dos árabes quer dizer "deserto", e contam que, nos tempos em que o rei Africo foi vencido pelos assírios, ou pelos etíopes, sendo ainda perseguido por seus inimigos ao fugir para o Egito e não encontrando maneiras de como se defender, pediu a suas gentes que o aconselhassem sobre qual partido tomar para salvar-se, pergunta que não foi respondida senão aos gritos de: "El bar bar"; ou seja, "ao deserto, ao deserto", querendo assim dizer-lhe que não se conhecia outro remédio senão, passando o Nilo, reduzir seus inimigos no deserto da África. Esse raciocínio concorda com aqueles que afirmam que a origem dos africanos se assenta nos povos da Arábia Feliz.
} 
O que chama a atenção em um primeiro momento é o fato de que esse relato se baseia no argumento da inexistência de população original em parte do continente. Não obstante, é precisamente a porção mediterrânea da África que é retratada como historicamente inabitada. Isso mostra que nenhum povo pode reivindicar qualquer legitimidade de posse da África a partir de argumentos de ancestralidade ou direito consuetudinário. O caminho está franqueado para a exploração colonial das cidades italianas e para a integração definitiva dessa região ao comércio com a Europa cristã. Em seguida, Leão Africano tenta construir duas outras justificativas para a tomada de posse da porção setentrional da África: 1) uma vez mais, a bestialidade dos que agora habitam essas terras, caracterizados como homens que se aproximam dos animais inclusive pelo pouco domínio da comunicação (importante ferramenta de comércio); e 2) a representação da África mediterrânea como terra de árabes fugitivos da Arábia Feliz.

Aqui, Leão Africano passa a nomear a região setentrional do continente como a terra de origem dos "africanos brancos" (Berberia e Numidia), em distinção a outra parte historicamente habitada do continente que é a já citada Terra dos Negros. A representação dessa segunda área da África é vinculada a um símbolo religioso monoteísta: a descendência de Noé:

"Gli Africani veramente della terra negra dipendono tutti dalla origine di Cus figliuolo di Cam, che figliuolo fu di Noè. Adunque, qual sia la differenza tra gli Africani bianchi e tra i neri, eglino tuttavia discendono quasi da una medesima origine, conciosiacosaché, se essi vennero da' Palestini, i Palestini medesimamente sono del legnaggio di Mesraim figliuolo di Cus, e se procedettero da' Sabei, Saba eziandio fu figliuolo di Rama, e Rama nacque pure di Cus. Sono molte altre oppenioni cerca ciò, le quali, per non esser cosa molto necessaria, mi parve di pretermettere. ${ }^{199}$,"

A separação retoricamente construída entre África habitada por brancos forasteiros e África negra nativa se dissolve por meio de referências a uma origem comum depreciativa, principalmente para os cristãos. Os africanos de modo geral seriam descendentes do filho amaldiçoado de Noé, Cam, uma imagem dos negros recorrente no imaginário cristão europeu. Ao lado da condição bestial dos nativos, a

\footnotetext{
199 "No que se refere aos verdadeiros africanos da Terra dos Negros, todos são originais de Cus, filho de Cam, que é filho de Noé. Assim, qual seja a diferença entre os africanos brancos e os negros, todos procedem quase que da mesma origem. Com o qual, se vieram da Palestina, os palestinos provém igualmente da linhagem de Mesraim, filho de Cus; e se procederam dos sabeus, seriam também provenientes de Cus, por meio de seu filho Rhama. Existem muitas outras opiniões sobre isso, e por não me parecerem necessárias, deixo-as de lado."
} 
maldição de Deus sobre Cam e seus descendentes fornece, novamente, subsídio simbólico para que, assim como o conceito khalduniano de "Umrān", um juízo facilmente reconhecido pelos europeus circule entre a África e a Europa na fluidez do trânsito cultural aproveitado por Leão Africano.

Em grande parte das alusões à África, o texto de Leão Africano define o continente por referências culturais adventícias. A necessidade de dar sentido e história à África e aos africanos a partir de signos asiáticos e europeus reforça a condição de "entre-lugar" que o continente adquiriu como espaço de negociação e conflito entre projetos imperiais de colonização a partir do século XVI, seja como rota marítima portuguesa para as Índias, ou como plano de expansão da influência política e econômica dos Medicis.

Dentre as culturas adventícias invocadas por Leão Africano para definir a África, a cultura árabe, percebida principalmente pela presença de sua língua, é um aspecto oportuno de análise:

"E quasi tutto il popolo di Gumera usa la favella araba, ma corrotta, e molti della stirpe della gente di Haoara parlano pure arabico, e tuttavia corrotto; e ciò aviene per aver lunghi tempi avuta conversazione con gli Arabi.

Nella terra negra favellasi in diverse lingue, una delle quali è da lor detta sungai, e questa serve a molte regioni, come è in Gualata, in Tombutto, in Ghinea, in Melli e in Gago. L'altra lingua essi chiamano guber, la quale è usata in Guber, in Cano, in Chesena, in Perzegzeg e in Guangra. Un'altra è tenuta nel regno di Borno ed è somigliante a quella che si costuma in Gaogà. Un'altra ve n'è ancora serbata nel regno di Nube, e questa partecipa dello arabico e del caldeo e della favella degli Egizii. Quantunque in tutte le città d'Africa, intendendo delle maritime poste sul mare Mediterraneo insino al monte Atlante, tutti quelli che vi abitano generalmente parlino nel linguaggio arabico corrotto, eccetto che in tutto il tener del regno di Marocco e in Marocco propio si favella nella lingua barberesca, e né più né meno nei terreni di Numidia, cioè fra i Numidi che sono a Mauritania e a Cesaria vicini, percioché quelli che s'accostano al regno di Tunis e al regno di Tripoli tutti universalmente tengono e usano la corrotta lingua arabica. ${ }^{200,}$

Ainda que seja restrita à parte do que Leão Africano chama de África, a língua árabe, quando apresentada nesse "entre-lugar", encontra-se na forma "corrompida",

\footnotetext{
200 "Quase todo o povo de Gumera usa a fala árabe, mas corrompida; e muitos da estirpe e gente de Aoara falam árabe, também alterado, o que ocorre por haver mantido conversação com os árabes durante muito tempo. Na Terra dos Negros falam-se diversas línguas, uma das quais é chamada por eles de sungai, e a falam em numerosas regiões, como Gualata, Tombutto, Ghinea, Melli e em Gago. A outra língua, chamam-na guber, e é usada em Guber, Cano, Chesena, Perzegreg e Guangra. Uma terceira é mantida no reino de Borno, e é semelhante à que se fala em Gaoga. Ainda se conserva outra língua no reino da Nubia e esta é influenciada pelo árabe, pelo caldeu, e pela fala dos egípcios; ainda que em todas as cidades da África (abarcando as marítimas sobre o Mar Mediterrâneo até o monte Atlas), todos os que ali habitam falam geralmente uma língua arábica corrompida; exceto em toda a extensão do reino do Marrocos, e no próprio Marrocos, onde se fala a língua berbere, assim como nos territórios da Numidia, tanto entre os númidas da Mauritânia e vizinhos de Cesaria, como entre os mais próximos dos reinos de Tunis e Trípoli, todos universalmente usam uma língua arábica corrompida."
} 
"adulterada", "degenerada". Dessa maneira, a África se transforma discursivamente em uma espécie de Arábia viciosa, contaminada pela inconstância entre sociedades nômades e sedentárias, árabes e berberes, brancas e negras, monoteístas e idólatras.

Essa característica fica mais evidente nos momentos em que o viajante descreve o que considera serem as posturas louváveis dos nativos, principalmente aqueles que vivem no litoral do Mar Mediterrâneo. É claro que quando se refere a "virtudes e coisas louváveis" dos africanos, não se trata de um reconhecimento tácito de que existam nativos com graus elevados de virtuosidade, mas sim que entre os africanos há níveis distintos de virtudes, variáveis de acordo com os critérios de classificação instituídos pela colonialidade.

Quanto ao elogio à virtude de certos nativos, Leão Africano relata:

"Gli Africani, cioè gli abitanti nelle città della Barberia e massimamente nella rivera del mare Mediterraneo, sono uomini che grandemente si dilettano di sapere, e si danno con molta cura agli studi: tra' quali quello della umanità e quello delle cose della fede e delle leggi loro tengono il primo luoco. Anticamente usavano di studiar nelle discipline matematiche, nella filosofia ed eziandio nell'astrologia; ma da quattrocento anni in qua, come s'è in parte detto, molte scienzie furono loro vietate dai dottori e dai principi loro, sì come fu la filosofia e l'astrologia giudiciaria. ${ }^{201,}$

"I negri sono di vita buona e fedeli, accarezzano molto i forestieri e danno tutto il loro tempo a piaceri e a far vita allegra, danzando e stando le più volte su conviti e in sollazzi di diverse maniere. Sono schiettissimi e fanno grandissimo onore agli uomini dotti e religiosi. E questi nell'Africa hanno il miglior tempo di tutti gli altri Africani che vi sono. ${ }^{202,}$

Essas passagens elucidam o teor classificatório das descrições sobre distintos povos africanos. Os sedentários e "arabizados" (habitantes da costa do Mediterrâneo) são reconhecidos por Leão Africano como homens mais reflexivos, dados à formação intelectual, mesmo que controlada por instâncias religiosas de poder, já que, ao falar em “dottori” e "principi”, o viajante faz referência ao reformismo teológico promovido pela dinastia Almoada no século XII, que aboliu o estudo das disciplinas incompatíveis com

\footnotetext{
201 "Os africanos que habitam as cidades da Berberia, e, principalmente, na costa do mar Mediterrâneo, são homens que se deleitam com o saber, e dão muita importância aos estudos; entre eles, os de humanidades e os das coisas da fé e da lei possuem o primeiro posto. Antigamente costumavam estudar disciplinas matemáticas, filosofia e astrologia, mas, nos últimos quatrocentos anos, como em parte já disse, muitas ciências foram tolhidas por seus doutores e por seus príncipes; como, por exemplo, ocorrido com a filosofia e a astrologia judiciária."

O termo "astrologia judiciária" faz menção ao que na Idade Moderna se considerava como a capacidade dos astros de influenciarem deliberadamente o destino dos homens. Com variações distintas ao longo do tempo, a maior parte dos doutores islâmicos e católicos condenou a astrologia jurídica por ser contrária à definição teológica de livre-arbítrio.

202 "Os negros levam uma vida boa; são fiéis, agradam aos forasteiros e dão todo o seu tempo ao prazer e a viver alegremente, dançando e estando, na maior parte do tempo, festejando, em divertimentos de diversos modos. São muito francos, dedicam grandes honras aos homens doutos e religiosos. Desfrutam melhor do seu tempo do que qualquer outro africano."
} 
a leitura estrita dos textos islâmicos sagrados. Em contrapartida, ao tratar dos negros, Leão Africano elege outros valores a serem destacados, atribuindo aos negros as virtudes de "fidelidade", "hospitalidade", "alegria", "franqueza" e "desfrutam melhor de seu tempo do que qualquer outro africano".

A escala de valores entre os povos africanos é um dos principais instrumentos de definição discursiva da África nas reflexões de Leão Africano. Por meio do trânsito de valores e adequação de seu texto ao que considera como os padrões culturais de seus leitores, o viajante organiza uma série de informações geográficas intercaladas de considerações sobre aspectos culturais dos nativos para cada vez mais acomodar seu texto às expectativas dos europeus, preparando argumentos de verdade que corroborem os ímpetos de exploração comercial do mundo, e, principalmente, dessa África relatada. Leão Africano sabe que escreve em uma época em que a Europa vive uma corrida comercial por mares e terras em todas as direções.

\subsection{Mare nostrum: ethos mercantil, vocabulário comercial e o uso do italiano}

A constatação de que a África é o espaço de circulação de pessoas, conceitos, mercadorias, e de trânsito de conceitos e culturas reforça a necessidade de se discutir certo jogo de significado que as palavras do viajante granadino sustentam no contexto em que foram produzidas. Em sua Della descrittione dell'Africa et delle cose notabli che ivi sono, Leão Africano elabora um léxico comercial voltado aos interesses de seu novo senhor, o Papa Leão X.

O chefe da Igreja Católica demonstrou muito interesse em conferir um caráter mais comercial à instituição que dominava. Giovanni de Medici, filho de Lorenzo, o Magnífico, cumpria uma missão familiar prestigiosa: garantir que a Igreja não se transformasse em um problema para a hegemonia política da família Medici em Florença, conquistada por meio do desenvolvimento comercial e artístico da cidade. Enquanto seu irmão mais velho, Piero, ficou com a responsabilidade de herdar o legado político de seu pai, Giovanni foi destinado à carreira eclesiástica, também vinculada ao plano familiar de estender suas fontes de autoridade fora de Florença.

Com uma trajetória eclesiástica ascendente, Giovanni de Medici assumiu importantes funções na Igreja, chegando à condição de cardeal-diácono aos 13 anos de 
idade durante o Papado de Inocêncio VIII (1484-1492), sob a condição de que não usaria qualquer insígnia nos três anos seguintes. Obteve sólida formação cultural e, assim como outros homens de sua época teve seu destino mudado drasticamente. Em 1512, durante a Batalha de Ravena, um enfrentamento entre o exército papal em coalizão com os espanhóis, e o exército francês unido ao Ducado de Ferrara, Giovanni de Medici foi capturado ${ }^{203}$.

A França venceu a batalha, mas paulatinamente foi perdendo suas conquistas na Itália. A passagem do ano de 1512 para 1513 foi uma virada triunfante para toda a família Medici. Um ano após a captura Giovanni de Medici estava livre, sua família retomou o poder incontestável em Florença e em 11 de março Giovanni era eleito Papa, adotando o título de Leão X e substituindo Julio II (1503-1513).

O pontificado do novo Papa foi marcado por controvérsias importantes, como o endividamento da Igreja e o surgimento da Reforma Protestante. John Hale, no verbete sobre Leão X de seu Dicionário do Renascimento Italiano, afirma que:

“O prazer de Leão X no Papado era óbvio. Pôde satisfazer o seu gosto pela caça e os banquetes, deleitando-se também em oferecer a hospitalidade de sua corte a homens de letras, intelectuais e agentes que aumentavam sua coleção de manuscritos clássicos. Bembo e Sadoleto estavam entre seus secretários, o cardeal Bibbiena era seu tesoureiro-geral. Rafael continuou trabalhando nas stanze do Vaticano, sendo para Leão X que ele desenhou a grande série de tapeçarias destinadas à Capela Sistina. (...) Para tanto, autorizou o funcionamento da sala de indulgências. Foram essas indulgências que levaram Lutero a criticar abertamente a Igreja" 204 .

À revelia de sua fama de péssimo administrador de finanças, seu período foi marcado por resultados positivos em outros campos. Na diplomacia, Leão X superou os embates ocorridos entre seu antecessor e a França ao conceder certo controle sobre a Igreja francesa ao rei Francisco I, por meio da Concordata de Bolonha. Além disso, nos anos em que comandou a Igreja, Leão X não viveu nenhuma grande guerra militar no território italiano, mas isso não significou um pontificado pacífico. As críticas de Martinho Lutero e o cisma da Igreja em 1517 garantiram tensões diplomáticas ao Papado, principalmente em relação aos nobres e príncipes alemães, à monarquia inglesa, e, posteriormente, à Holanda e à Suíça.

Entretanto, o aspecto que mais se relacionava com o legado positivo de Leão $X$ era sua institucionalização do mecenato. Dentre os homens de letras que recebeu em sua

\footnotetext{
203 ' 'Com'è noto, Giovanni de' Medici partecipò, come Legato di Papa Giulio II, alla battaglia di Ravenna, al termine della quale fu catturato". Mario Traxino. La Bataglia di Ravenna (11 Aprile 1512). http://www.mariotraxino.it/la\%20battaglia\%20di\%20Ravenna.pdf

${ }^{204}$ Verbete: Leao X. (IN) John Hale. Op.cit. p. 202.
} 
corte estava al-Hasan ibn Muhammad al-Wazzan al-Fasi, o futuro João Leão Africano. A elaboração de Della descrittione dell'Africa et delle cose notabli che ivi sono esteve relacionada às preocupações do Papa, principalmente por sua vigilância aos interesses de Florença fora da Itália. Por essa razão, ao longo do seu capítulo geral sobre a África, João Leão Africano apresenta em sua narrativa a identificação dos produtos potencialmente exploráveis pela presença colonial, sendo fiel aos interesses não somente do Papa, mas de toda a família Medici.

O primeiro indício do interesse comercial como um dos principais objetivos de seu relato de viagem é a própria maneira com que Leão Africano recorre a toponímias que destacam as potencialidades comerciais de uma dada região da África. Ao tratar, por exemplo, da Numidia ${ }^{205}$, o viajante intitula essa parte de sua obra como: "Divisione di Numidia, cioè dei paesi dove nascono $i$ datteri ${ }^{206 " . ~ E m ~ o u t r o ~ m o m e n t o ~ d o ~ t e x t o, ~ a o ~}$ se referir à expectativa de vida dos africanos, Leão Africano retoma: "In Numidia ancora, ciò̀ nel paese dei datteri ${ }^{207 ", ~ N e s s a s ~ p a s s a g e n s ~ e ~ e m ~ o u t r a s ~ o c a s i o ̃ e s, ~ a ~}$ Numidia é citada pelo produto que possui em abundância, o que facilita a localização da potencialidade econômica da região e o interesse para a transformação dessas terras em área de exploração futura. Desse modo, a Numidia passa da condição de "terra onde nascem os dátiles", para a própria “região/terra dos dátiles".

Outro caso oportuno ocorre com a chamada "Terra dos Negros". Ao mencionar a região conhecida como Bilad as-Sudan (بلاد السودان), da mesma maneira com que identificava a Numidia pelas tâmaras, Leão Africano refere-se ao Sudão ocidental e Sudão oriental como uma região com potencial econômico para a exploração de escravos negros, um comércio em ascensão ao longo do século XVI, mas que deslocava-se gradualmente em direção ao Atlântico. Das tâmaras aos negros, a geografia e a definição espacial de João Leão Africano encontram-se alicerçadas em um vocabulário comercial que não se concentra na descrição física dos produtos, mas na localização de mercadorias de grande valor econômico para o comércio europeu.

A inclusão dos negros na categoria de mercadorias a serem exploradas não se limita à escravidão desses africanos, mas também de outros povos submetidos à possível condição de cativeiro e sujeição:

\footnotetext{
205 Atuais territórios da Argélia e parte da Tunísia.

206 "Divisão da Numidia, ou seja, da terra onde nascem as tâmaras".

207 "Na Numidia também, que é a região das tâmaras...".

${ }^{208}$ Atuais territórios do sul do Deserto do Saara em direção ao Centro-Oeste do continente africano.
} 
"Per la qual cosa aviene che ad ogni tempo si truovano molti figliuoli dei detti Arabi appresso i Siciliani, lasciati loro per pegno e securtà di grano che i poveri uomini pigliano in credenza. E se fra certo termine convenuto nei mercati non pagano la somma dei danari che sono debiti, i creditori tengono i figliuoli per ischiavi, e volendogli i padri riscuotere converrebbe accattar tre volte maggior quantità del debito, di modo che sono costretti a lasciarvegli. ${ }^{209}$,

Nessa passagem fica explícita a relação entre os sicilianos e o sequestro de pessoas na costa africana. Somados às discussões já mencionadas aqui sobre a desordem que imperava nas águas do Mediterrâneo, o cativeiro e comércio de reféns era uma prática comum entendida por Leão Africano a partir de uma lógica comercial direta. Esse trecho pode ser percebido como essencial para a formação do vocabulário comercial do viajante, não somente por corroborar a condição mercantil do homem do século XVI, mas também pelo fato de que o próprio Leão Africano, ainda al-Hasan ibn Muhammad al-Wazzan al-Fasi, foi vítima de piratas sicilianos e transformado em mercadoria pelo comércio de escravos.

Além disso, outro elemento comercial importante pode ser identificado nessa passagem. No Mediterrâneo do século XVI, o trigo transformou-se em uma espécie de moeda corrente do mercado de escravos. Os traficantes negociam trigo com os nativos e tomam seus filhos como fiança. O caso do trigo como mercadoria e moeda ganha visibilidade na obra de Leão Africano também quando adquire uma terceira função:

\footnotetext{
"Questi Arabi fanno lavorare i loro terreni e vi cavano grandissima copia di grano. Hanno di pecore e di buoi un numero quasi infinito, e per questa cagione non si possono fermare in un luogo solo, percioché un terreno non basta a pascer tante bestie. Sono eziandio più barberi quasi e vili di natura di quei del diserto, ma sono nondimeno liberali, e una parte di loro, la quale abita nel regno di Fez, è soggetta e tributaria del $\mathrm{re}^{210}$."
}

A comunidade nativa chamada aqui por Leão Africano de "árabe" é, na verdade, tuaregue. A organização social e política de parte desses indivíduos mantém-se autônoma em relação a outros poderes locais por sua capacidade de estocagem de grandes quantidades de grãos/trigo. A condição de nômades criadores de víveres, somada à grande oferta de cereais, permite a esses tuaregues garantir a subsistência da

\footnotetext{
209 "Por isso, constantemente, muitos jovens árabes são entregues aos sicilianos como penhor ou fiança por grãos, e se, dentro de um tempo acertado não se salda a dívida, ficam como escravos, devendo os pais entregar, para resgatá-lo, uma quantidade três vezes maior da devida; de modo que muitas vezes são forçados a deixá-los nessa condição.”

210 "Esses árabes trabalham suas terras e estocam grandíssima quantidade de grãos (trigo), possuem ovelhas e bois em um número quase infinito, e, por essa razão, não se põem a fixar-se em um único lugar, já que um terreno não basta para alimentar tantos animais. São, por sua vez, mais bárbaros e naturalmente vis que a gente do deserto, mas são, não obstante, livres, ainda que uma parte deles, que vive no reino de Fez, está submetida ao pagamento de tributos a seu rei."
} 
comunidade. Dessa forma, esses indivíduos conservam relativa autonomia que os coloca sob uma condição destacada na região, já que não pagam tributos a nenhum senhor. Nesse caso, Leão Africano sugere que o trigo, pela sua escassez em partes da África, confere um status privilegiado aos que possuem esse recurso, estabelecendo, como no caso do exemplo dos cativos anteriormente citados, uma relação direta entre o valor comercial do trigo e sua função autárquica. A cultura muçulmana já reconhecia a importância do trigo na alimentação cotidiana de sua população antes do século XVI. As pastas feitas de trigo, que se acreditava terem sido trazidas à Europa por Marco Polo, eram, de fato, produtos alimentícios difundidos por regiões do Mediterrâneo islâmico, principalmente no sul da Sicilia ${ }^{211}$.

Provavelmente, Leão Africano viveu no Norte da África e foi mantido prisioneiro na Sicília, mas sabia da importância comercial do trigo para os italianos em geral. É fato que a experiência colonial europeia nas Américas alterou profundamente o comportamento alimentar dos europeus com a inclusão de produtos do Novo Mundo na dieta cotidiana dos povos colonizadores. O tomate, a batata e o milho são os exemplos mais evidentes dessa revolução gastronômica. Mas, mesmo antes da vinda desses produtos, a oferta de produtos comestíveis já havia sofrido uma grande transformação na Europa com a chegada de alimentos próprios da cultura culinária árabe-islâmica como o açúcar, os frutos secos e, até mesmo, a pasta de trigo.

De modo mais contido, a criação de animais aparece como um recurso comercial importante na África. O abastecimento de carne de certos animais é indicado por Leão Africano pelo fato de sua escassez na alimentação tradicional da grande maioria da população europeia ser conhecida. Ainda que não houvesse tanta dificuldade para se encontrar aves e porcos na Europa do século XVI, a valorização de alguns rebanhos como recurso comercial era justificada. Novamente a passagem sobre o povo "sahid" deve ser analisada:

"Sahid abitano similmente nei deserti di Libia; costoro sogliono tener domestichezza e conversazion nel regno di Guargala, hanno infiniti bestiami, e forniscono di carne tutte le città e luoghi che confinano coi

\footnotetext{
211 "Recientes estudios demuestran también que el uso de la pasta de trigo, que hasta ahora creíamos que había traído Marco Polo del lejano Oriente, se consumía en Sicilia musulmana y en otras zonas del Mediterráneo de dominación árabe." Joaquin Prats et Carina Rey. Las bases modernas de la alimentación tradicional. Prats J, Rey C. Las bases modernas de la alimentación tradicional. (IN) Martínez López JM (ed.). Historia de la alimentación rural y tradicional. Recetario de Almería. Almería, Instituto de Estudios Almerienses, 2003; 53-62.
} 
loro diserti; ma ciò nel tempo della state, percioché il verno non si partono dal diserto. Sono di numero appresso centocinquantamila, ma pochi cavalli hanno ${ }^{212}$."

No interior do relato de viagem os "sahid" ganham importância por representarem não somente a prática do comércio de carne na região, mas, sobretudo, por terem rebanhos que garantem o fornecimento do produto a lugares próximos. Esse é o tipo de informação que interessa aos principais leitores desse registro geográfico. $\mathrm{O}$ mapeamento das conexões mercantis de determinado produto confunde-se com a descrição geográfica da região, já que se encontra definido o comportamento migratório dos "sahid" a partir das variações climáticas das estações.

A relação entre comércio e conhecimento geográfico na obra Della descrittione dell'Africa et delle cose notabli che ivi sono se constrói também pelas informações dadas pelo viajante sobre os produtos encontrados com fartura na vida cotidiana de certos grupos. Um exemplo dessa relação pode ser percebido na menção que Leão Africano faz aos povos que habitam os desertos próximos a Telensin e Tunis e aos que habitam os "lugares selvagens e nevados":

\begin{abstract}
"Sogliono il tempo della state andare a' confini di Tunis a pigliar le provisioni loro, e l'ottobre si forniscono di ciò che fa lor bisogno, sì come di vettovaglie, di panni e d'arme, e con queste ritornando nei diserti vi rimangono tutto il verno. Poscia la primavera si sollazzano nelle caccie, con cani e falconi seguitando ogni sorte di fiere e di uccelli. E io molte volte ho alloggiato con loro e mi sono valuto di molte cose, e hogli veduti nei lor padiglioni più forniti di panni, di rami, di ferri e di ottoni che non sono molti nelle cittadi.", 213
\end{abstract}

"Per tutti i detti monti nascono grani e frutti, ma frumento non molto in copia, e gli abitanti la più parte dell'anno mangiano pane di orgio. I fonti che si trovano per li detti monti hanno certe acque che tengono il sapore del terreno e sono quasi torbide, e massimamente nelle parti che confinano con Mauritania. Sono eziandio sopra i detti monti molti boschi di alberi altissimi, e le più volte pieni d'animali, quai buoni e quai cattivi. Ma i piccoli colli e le pianure che sono fra i detti monti e il monte Atlante sono tutti buonissimi terreni, che producono gran quantità di grani e d'ottimi frutti; e per tutti i detti colli e pianure passano tutti i fiumi che nascono di Atlante e vanno al mare Mediterraneo."214

\footnotetext{
212 "Os Sahid habitam também o deserto da Líbia, e se desenvolvem com familiaridade no reino de Guargala. Possuem infinitos rebanhos e fornecem carne a todas as cidades e lugares próximos a seus desertos, mas, isso ocorre, sobretudo, no verão. Durante o inverno, não saem de seus desertos.”

213 "São afeitos, no verão, a viagens até os confins de Tunis para se apoderarem de provisões, e em outubro se abastecem do que necessitam: do pão e de armas, e, com isso, retornam ao deserto, onde permanecem por todo o inverno. Depois, na primavera, divertem-se nas caças com cães e falcões, perseguindo toda a sorte de feras e de aves. Muitas vezes me alojei com eles, e me foi valioso por muitas coisas, e vi suas tendas mais providas de panos, de cobre, de ferro e de bronze, do que muitas das casas das cidades."

214 "Em todos esses montes nascem grãos e frutas, mas não muito trigo, de modo que seus habitantes comem, na maior parte do ano, pão de cevada. As nascentes de água que se encontram nesses montes possuem certa água que tem o sabor terroso e são quase turvas, principalmente na parte que faz fronteira com a Mauritânia. Crescem nesses montes grandes bosques com árvores altíssimas, cheios de animais bons e maus, mas as pequenas colinas e as planícies que estão entre os tais montes e o Atlas são todas de
} 
As indicações de abundância de determinados artigos de valor comercial como animais, tecidos, armas, metais, frutas e grãos se combinam à informação de recursos de sobrevivência como a água (ainda que turva e terrosa). Os dados destacados aqui por Leão Africano sugerem a possibilidade de se considerarem ambas as regiões como possíveis rotas comerciais. A região de Tunis e as montanhas da Mauritânia já eram conhecidas por diversos povos no século XVI, porém subexploradas. Havia uma rota marítima que conectava diretamente Gênova a Tunis, e em seguida, por via terrestre, chegava-se a rotas terrestres trans-saarianas até a chamada "Terra dos negros", mas essas vias internas não eram controladas por nenhuma grande cidade comercial europeia. É sobre essas rotas africanas internas que Leão Africano se debruça.

Havia notícias de que principalmente os portugueses tinham acesso a portos e regiões costeiras da África ocidental, mas, no século XVI esse contato ainda era feito por vias marítimas que permitiam o controle lusitano de alguns desses portos. Um dos pontos mais notórios do acesso dos portugueses a rotas comerciais internas da África era a cidade de Azafi (em português: Safim), na costa marroquina. Em seu trabalho sobre a imagem de Portugal e dos portugueses na obra "Delle Navigationi et viaggi", de G.B. Ramusio (que inclui o texto de Leão Africano), Luciana Picchio ressalta a maneira pejorativa com que o viajante granadino se referia aos portugueses, certamente em sintonia com o incômodo que a expansão lusitana na costa da África causava aos italianos, em especial a florentinos, genoveses e venezianos ${ }^{215}$.

O século XVI é marcado pela disputa dos grandes impérios europeus como Portugal, Espanha e França pelo controle de caminhos e terras a serem revelados pela navegação do Oceano Atlântico. Já as repúblicas italianas tentavam manter o domínio sobre as rotas marítimas do Mediterrâneo conquistadas nos séculos anteriores ${ }^{216}$. Isso

boníssimas terras, que produzem grande quantidade de grãos e ótimos frutos, e por todas as colinas correm os rios que nascem no Atlas e seguem em direção ao mar Mediterrâneo."

215 “... Giovan Lioni Africano vê Portugal e os portugueses na óptica islâmica e é para nós equilibradora e instrutiva esta imagem duma Europa devastadora de terras marroquinas que se espelha na lúcida prosa do Embaixador dos Wattásidas. (...) Os portugueses de Giovan Lioni são de início 'molestadores'... (...) Depois, com a conquista dos portos marroquinos de Safim (1508) e Azamor (1513), os portugueses tornam-se 'arruinadores' de cidades e escravizadores de homens." Luciana Stegagno Picchio. Portugal e portugueses no livro "Navigationi” de G.B. Ramusio. IV Reunião Internacional de História da Náutica e da Hidrografia, Sagres-Lagos, julho 1983. pp. 13-14.

216 "Para muitos historiadores, as viagens pelo Mar Tenebroso, como era conhecido o oceano Atlântico por se supor que nele habitavam monstros e seres aterrorizadores, e a descoberta do continente americano, no final do século XV e início do século XVI, assinalaram o começo dos Tempos Modernos. Ao se aventurarem para além dos limites do Mediterrâneo, dominado até então pelos italianos que, nos séculos precedentes, incentivaram o comércio com o Oriente e animaram a vida econômica das repúblicas italianas, os navegadores a serviço dos reis da Espanha e de Portugal realizaram um feito cujas 
explica o aumento do interesse dos povos italianos pelos confins do que muitos cristãos e muçulmanos no século XVI consideravam ser a África: sua costa mediterrânea e as terras interiorizadas que se conectavam com portos já conhecidos pelos europeus. Por essa razão, esse mundo potencialmente comercial a ser explorado se revela na narrativa de Leão Africano não somente na identificação direta dos produtos negociáveis, mas também na descrição de situações sociais de contato entre os nativos e o viajantemediador cultural. Uma passagem que evidencia essa dinâmica de proximidade é a descrição que o viajante faz de um banquete oferecido pelo príncipe de Zanaga, no deserto líbio:

"La somma del convito fu di carni arroste e lesse; gli struzzi furono arrosti, e recatici alla mensa in certe teglie cariche d'erbe e di buona quantità di spezie della terra negra. Il pane era fatto di miglio e di panico, schiacciato e molto sottile. Ultimamente ci furono portati datteri in molta abbondanza e vasi grandi pieni di latte. Il signore ancora egli volle onorare il convito della sua presenza insieme con alcuni de' suoi più nobili e parenti di lui, ma da noi separati mangiarono. Fece venire ancora alcuni religiosi, e quei litterati che si trovavano a seder con lui. E mentre si mangiò niun di loro toccò mai pane, ma solo presero delle carni e del latte. Per il che accorgendosi il principe, a certi nostri atti, che noi di ciò eravamo rimasi stupefatti molto e pieni di maraviglia, ci rispose con parole piacevoli, dicendo che eglino erano nati in quegli diserti ne' quali non nasceva grano, perciò si nudrivano di quello che produceva il loro terreno, e che del grano si provedevano ciascun anno per onorare i forestieri che passavano di là. ${ }^{217}$,"

Algumas informações apresentadas na exposição dos pratos do banquete revelam a dinâmica das rotas comerciais internas da África aqui descrita. Se em pleno deserto líbio os avestruzes vão à mesa com vegetais e especiarias da Terra dos Negros, significa que existe acesso fácil dos portos líbios do Mediterrâneo a esses produtos vindos de outra parte do continente africano, configurando uma incipiente rota de comércio explorável entre a Líbia e a Terra dos Negros. Esse argumento se confirma quando o viajante assegura que foram servidos dátiles (tâmaras) em abundância. Isso mostra que o deserto da Líbia tinha acesso tanto ao Sul (Terra dos Negros) como a Oeste (a Numidia, ou Terra das tâmaras). É possível que esse cruzamento de rotas já

consequências em muito extrapolaram os objetivos incidais de suas viagens." Berenice Cavalcante et ali. Modernas tradições: percursos da cultura ocidental. Séculos XV - XVII. Rio de Janeiro: ACCESS Editora, 2002. p. 21.

217 "O banquete era composto de carnes assadas e cozidas, os avestruzes foram assados e levados à mesa em tabuleiros cheios de vegetais e boa quantidade de especiarias da Terra dos Negros. O pão era feito de miglio e panico, achatado e muito fino. No final foram servidos dátiles em abundância, grandes tigelas cheias de leite. Além de sua presença, O príncipe quis honrar o banquete com a participação de alguns de seus nobres e parentes, embora tenham comido à parte de nós. Fez virem também alguns religiosos e literatos, que foram sentar-se com ele. E enquanto durou o banquete, nenhum deles tocou no pão, mas apenas a carne e o leite. Percebendo o príncipe que aquilo nos assombrava e maravilhava, disse-nos com palavras agradáveis que nenhum deles era nascido naquele deserto que não gerava grãos, por isso se alimentavam dos produtos originários de sua terra natal e buscavam esses grãos todo ano para oferecer em honra aos forasteiros de passagem." 
fosse conhecido por alguns europeus, mas o que chama a atenção nas palavras de Leão Africano é que ele utiliza um vocabulário sedutor aos mercadores italianos ao falar em "especiarias" e "abundância" em uma passagem sobre uma região desértica.

E, por fim, de maneira mais intrigante, Leão Africano reforça a condição do deserto da Líbia como entre-caminho de rotas comerciais ao afirmar que, mesmo sem produção de grãos naquele deserto, buscava-se esse produto para ser oferecido de maneira hospitaleira aos forasteiros. Se há acesso a um produto adventício, há mobilidade comercial.

Entre rotas comerciais e descrições geográficas vive o homem que circula pelos caminhos do comércio africano. Ao falar da África como espaço de interstício e trânsito de culturas, Leão Africano fala também da sobrevivência nessas terras de certo caráter mercantil, um conjunto de características descritas pelo viajante-mediador de culturas que negocia para o leitor a ser persuadido a imagem do narrador e dos que são descritos. A partir dessa dinâmica narrativa de valorização dos atributos comerciais dos nativos, o relato de viagem utiliza como estratégia de convencimento das potencialidades econômicas da África a afirmação de uma espécie de ethos comercial entre os africanos, e, inclusive, no próprio narrador, que de al-Hasan ibn Muhammad al-Wazzan al-Fasi (muçulmano granadino) se converte em João Leão Africano (cristão “africano"). Nessa perspectiva, ao tratar da possibilidade de se estender o conceito de ethos às "imagens de outrem", Melliandro Galinari afirma que o ethos não se circunscreve a uma visão de "si mesmo" daquele que recorre a este artifício para no discurso persuadir, mas também atua sobre a imagem que se atribui a seres, coisas e instituições tematizados por dado discurso $^{218}$.

A condição de "negociante" atribuída aos nativos forma um dos elementos mais importantes da definição fluida e retórica de África presente no capítulo geral de Della descrittione dell'Africa et delle cose notabli che ivi sono. Parte do ethos mercantil africano se constrói pelo reconhecimento de um papel fundamental exercido pelo negociante no século XVI: o de servir também como "informante”. Em duas passagens, Leão Africano ressalta essa condição:

\footnotetext{
218 "Sem meias palavras, e já terminando, acredito que poderíamos construir análises discursivas destinadas a elucidar os 'ethé de outrem', o que estenderia o ethos não apenas às imagens de si das instâncias de produção dos discursos abordados, mas também às imagens de seres/coisas ou instituições tematizados por esses mesmos discursos. O ethos, assim, não se resumiria, no plano teórico, ao conhecido jargão 'imagens de si', mas se estenderia também ao que poderíamos chamar de 'imagens de outrem'." Melliandro Mendes Gallinari. Sobre ethos e AD: tour teórico, críticas, terminologias. DELTA [online]. 2012, vol.28, n.1, pp. 51-68. ISSN 0102-4450. http://dx.doi.org/10.1590/S0102-44502012000100003.
} 
"La quarta parte, che è la terra de' negri, dalla parte di oriente incomincia dal regno di Gaogà e procede verso occidente insino a Gualata; e dalla parte di tramontana confina con i diserti di Libia, e dal lato di mezzogiorno termina al mare Oceano: luoghi incogniti appresso di noi, ma pure molta notizia ne abbiamo da mercatanti che vengono da quella parte al regno di Tombutto ${ }^{219,}$

"Ancora la terra negra è divisa in molti regni, di quali nondimeno alcuni sono incogniti e lontani dal commerzio nostro. Per il che di quelli dirò ove sono stato io e ho avuta lunga pratica, e di quegli altri ancora da' quali partendosi i mercatanti che le lor mercanzie contrattavano nel paese dove io era, me ne diedero buona informazione ${ }^{220,}$

Essa rede de informações identificada por Leão Africano é um elemento fundamental para se entender um dos objetivos mais contundentes do relato de viagem sobre a África. Grande parte do conhecimento geográfico no século XVI se estabelecia muito mais pela circulação de informações entre circuitos intelectuais e mercantis, do que pela produção acadêmica dos pensadores renascentistas. Plínio Freire Gomes, em seu trabalho sobre redes de informação e cultura geográfica no Renascimento, defende a importância do saber empírico do "ouvir-dizer", mais facilmente acessível do que os informes dos eruditos do período ${ }^{221}$.

É nesse contexto que a atuação dos mercadores como informantes ajuda a compor nos filhos da África o ethos mercantil. A condição fluida e móvel do africano o transforma em negociante de produtos e notícias, um elemento a ser explorado pelos mercadores europeus, já que, nas palavras de Leão Africano: “(existem) lugares desconhecidos por nós, mas que temos muitas notícias por causa dos mercadores...”.

Entretanto, apesar de Leão Africano estimar a face mercantil daqueles que habitam a África e entender-se como um forasteiro em um espaço de interstício, o

\footnotetext{
219 "A quarta região, a Terra dos Negros, começa, partindo do Oriente, pelo reino de Gaoga, segue a Ocidente até Gualata, e se alarga ao Norte até os desertos da Líbia, acabando a meio-dia no Mar Oceano, lugares desconhecidos por nós, mas que temos muitas notícias por causa dos mercadores que chegam ao reino de Tombuctú."

220 "Esta Terra dos Negros está também dividida em muitos reinos, ainda que alguns continuem desconhecidos e apartados de nosso comércio. Falarei, portanto, de onde passei e tive longa experiência, assim como de outros caminhos por onde partiram mercadores que comerciaram suas mercadorias no país em que me encontrava e me abasteceram de boas informações".

${ }^{221} \mathrm{Na}$ verdade, a chave para compreender a geografia renascentista não está na intuição, no gênio dos humanistas. Está, sim, na irradiação do saber e na tensão entre circuitos (de trocas intelectuais) ligados como numa teia que se espalhava por todo o continente europeu. Esta é a estrutura vasta e assimétrica, que abrangia conhecimentos empíricos e livrescos, espionagem e propaganda, aparatos estatais e simples curiosos, a explicar o sucesso dos planisférios. Também é ela a formar a audiência transnacional, cuja demanda daria origem, na segunda metade do século XVI, aos teatra mundi e às grandes coleções de relatos de viagens, de Ramusio a Theodor de Bry. Plínio Freire Gomes. Volta ao mundo por ouvir-dizer: redes de informação e a cultura geográfica do Renascimento. An. mus. paul., São Paulo, v. 17, n. 1, June 2009. $\quad$ http://www.scielo.br/scielo.php?script=sci arttext\&pid=S0101$\underline{47142009000100008 \& \operatorname{lng}=e n \& n r m=i s o}$. http://dx.doi.org/10.1590/S0101-47142009000100008 .
} 
viajante acaba incorporando o próprio "ethos de outrem" que mapeia em seu relato ao recorrer a um vocabulário comercial ao longo de sua descrição dos povos e terras da África. Um conjunto de palavras utilizado pelo viajante em sua narrativa revela duas grandes preocupações que norteiam o mundo comercial cotidiano do espaço de interstício: a forma de se fazer comércio dos africanos (trato mercantil) e a segurança dos negócios (noção de incerteza).

Alguns dos vocábulos que remetem diretamente às relações de comércio, assim como toda a narrativa sobre a África, são extraídos do "italiano" vulgar, um signo forte do paulatino sucesso que as línguas vernáculas faziam no prelúdio da modernidade. Merece destaque o fato de que em nenhum momento o latim é uma referência absoluta para Leão Africano, mesmo sabendo que essa língua era o idioma franco dos círculos diplomáticos europeus em fins do século XV e início do XVI. A trajetória de vida de Leão Africano sugere que ele manejava com certa tranquilidade o latim quando escreveu Della descrittione dell'Africa et delle cose notabli che ivi sono, apesar de não ser conhecido pelo domínio desse idioma.

Como diplomata e alto funcionário em distintas partes do Mediterrâneo islâmico, mesmo que não dominasse perfeitamente o latim, ele deveria ser capaz de entendê-lo pelas necessidades cotidianas de seu ofício diplomático nessa região. Uma prova do contato estreito que o viajante granadino tinha com o latim foram seus trabalhos nos anos em que viveu na corte papal. Já como analista dos textos árabes da Biblioteca do Vaticano $^{222}$, Leão Africano, por exemplo, corrigiu a tradução do Alcorão para o latim, iniciada em 1518 por Joannes Gabriel de Teruel, e participou, em 1524, da elaboração de um dicionário árabe-hebraico-latim junto com o intelectual judeu Jacob Mantino ben Samuel.

Mas, apesar de todas essas referências que reforçam a importância do latim no circuito intelectual do início do século XVI, Leão Africano escreveu sua obra sobre a África em "italiano" vulgar, com os auspícios de seus senhores eclesiásticos. Peter Burke, ao discutir o papel do latim nos primórdios da Europa moderna, aponta alguns caminhos para o entendimento dos motivos que levaram o protegido árabe a escrever em língua vernácula. Nas palavras de Burke: “uma das vantagens do latim nos círculos

\footnotetext{
222 "al-Wazzan was treated well enough to be loaned manuscripts in Arabic from the Vatican Library within a month of his arrival in 1518. The Arabic collection at the Vatican, originating in the religious and scholarly interests Pope Nicholas $V$ in the mid-fifteenth century and now encouraged by Leo X, was not extensive, but there was enough to keep al-Wazzan busy." Natalie Zemon Davis. Trickster Travels: a Sixteenth-Century Muslim between worlds. New York: Hill and Wang, 2006, pp. 57-58.
} 
diplomáticos era o fato de ser uma língua relativamente conhecida pelos membros da elite; uma segunda razão era o fato de ser uma língua de prestígio, e uma terceira era o fato de ser neutra em comparação com os vernáculos que competiam pela hegemonia cultural da época, com destaque para o italiano, o espanhol e o francês ${ }^{223}$ ".

Pode-se considerar como parte do projeto de poder papal desenvolvido a partir de Leão X garantir a supremacia cultural do italiano, tão caro à sua Florença natal, e ao desejo de expansão da influência política da família Medici na Europa por meio do papado. Nessa perspectiva, Leão Africano e sua espionagem sobre as potencialidades comerciais da África deveriam refletir esse projeto. Ao mesmo tempo que o viajante granadino deixava de ser muçulmano para ser cristão forçosamente, abandonava também suas atribuições de espião-diplomata para ser o espião-viajante, o que também lhe compelia a operar com a língua vernácula em detrimento do latim "profissionaldiplomático".

Outra explicação plausível para o uso do "italiano" vulgar estava relacionada ao objetivo central da obra Della descrittione dell'Africa et delle cose notabli che ivi sono. Ciente do espaço conquistado pelas línguas vernáculas no mundo dos negócios do século XVI, nada mais coerente do que escrever um relato dos aspectos comerciais da África em "italiano" vulgar, justamente a língua que Leão Africano aprendeu para negociar situações de sobrevivência enquanto fora mantido cativo na Península Itálica, em conversas cotidianas com membros da corte papal, carcereiros, soldados e outros prisioneiros $^{224}$.

Os vocábulos que sugerem a preocupação com o trato mercantil na referida obra de Leão Africano são muitos, e alguns, em especial, estão diretamente vinculados a este propósito, tais como:

\begin{tabular}{|l|l|l|}
\hline $\begin{array}{l}\text { Vocábulo } \\
\text { (trato mercantil) }\end{array}$ & Original & Trecho \\
\hline Caravaneiro & Camelleri & $\begin{array}{l}\text { “... porque os árabes } \\
\text { e os caravaneiros }\end{array}$ \\
\hline
\end{tabular}

\footnotetext{
${ }^{223}$ Peter Burke. Linguagens e comunidades nos primórdios da Europa Moderna. São Paulo: Editora UNESP, 2010. pp. 61-62.

224، At the same time, al-Wazzan must have been improving whatever skills He had brought with him in Italian and Latin languages through conversations with his jailers, the Castel soldiers, and other prisoners (a bankrupt Roman financier was clapped into a cell not long after al-Wazzan's arrival); with the Vatican librarian and other churchmen; and with Leo X himself. He would have known a version of Spanish from his boyhood, as we have seen, though He would have written it more likely in Arabic (aljamiado) than in the Latin alphabet. He may well have known some Portuguese, learned from Sultan Muhammad al-Burtughali; and He may have had a smattering of Italian, acquired in conversations with Genoese and other Italian merchants at Fez and Tunis." Natalie Zemon Davis. Op. cit. p. 58.
} 


\begin{tabular}{|c|c|c|}
\hline Comercialização/Negócio & $\begin{array}{l}\text { il mestieri della } \\
\text { mercanzia }\end{array}$ & $\begin{array}{l}\text { que executam o } \\
\text { trabalho de } \\
\text { comercialização de } \\
\text { dátiles, levam } \\
\text { consigo infinita } \\
\text { quantidade de trigo } \\
\text { para fazer escambo } \\
\text { pelos dátiles..." }\end{array}$ \\
\hline Comerciantes & mercatanti & $\begin{array}{l}\text { "e é de grande } \\
\text { perigo aos } \\
\text { mercadores essa } \\
\text { viagem em qualquer } \\
\text { estação que não seja } \\
\text { o inverno" }\end{array}$ \\
\hline Comerciar & $\begin{array}{l}\text { Fanno } \\
\text { mercanzie }\end{array}$ & $\begin{array}{l}\text { "Sabem comerciar } \\
\text { com seus camelos } \\
\text { na Terra dos Negros } \\
\text { e tendo cavalos em } \\
\text { grande número: os } \\
\text { que na Europa são } \\
\text { chamados de } \\
\text { cavalos berberes." }\end{array}$ \\
\hline Impostos/ganhos & Tributi & $\begin{array}{l}\text { "Outra parte do } \\
\text { povo de Emrun tem } \\
\text { domínio sobre } \\
\text { algumas terras e } \\
\text { casas da Numidia, } \\
\text { até o deserto de } \\
\text { Fighig, as quais } \\
\text { proporcionam a eles } \\
\text { muitos e } \\
\text { consideráveis } \\
\text { tributos." }\end{array}$ \\
\hline Taxa & gabella & $\begin{array}{l}\text { “...passam por duas } \\
\text { dificuldades nada } \\
\text { pequenas: uma a de } \\
\text { pagar aos árabes } \\
\text { autorizados pelo rei } \\
\text { uma grandíssima } \\
\text { taxa..." }\end{array}$ \\
\hline
\end{tabular}


No tocante à atividade comercial dos africanos os termos "caravaneiro", "comercialização/negócio", "comerciantes" e "comerciar" se apresentam como recursos linguísticos diretamente ligados à atividade mercantil, transformando o comércio e a caravana em classes gramaticais distintas como substantivo, verbo e adjetivo. Mesmo pelo meio de expressões compostas como "fanno mercanzie", o uso dessa combinação de palavras cria um significado inteiramente relacionado ao ofício mercantil. O vocabulário específico que Leão Africano utiliza para se referir aos africanos e suas práticas de interação socioeconômica não chega a definir um jargão particular, mas mostra a circulação da experiência mercantil no cotidiano da Península Itálica do século XVI, principalmente no universo da língua vernácula.

De acordo com Burke, o sentido de "jargão" como um conjunto de palavras técnicas ou de ofício específico somente se consolida nos séculos XVII e XVIII ${ }^{225}$, o que permite a definição do vocabulário comercial de Leão Africano mais como um reforço à importância da experiência mercantil nessa época, do que a caracterização de um campo profissional exclusivamente voltado às relações econômicas. Além disso, a presença marcante dessas palavras comprova o propósito comercial da obra e a disposição habitual dos homens do século XVI à negociação constante, seja de produtos ou mesmo da própria sobrevivência, como no caso de Leão Africano.

Falar em comércio no século XVI é também tratar de questões ligadas às relações sociais. Nesse sentido, o caso da expressão "il mestieri della mercanzia" mostra que a relação do termo com a atividade comercial não está apenas no uso da palavra "mercanzia" (mercadoria), mas também em "mestieri", como "arte", “procedimento", “artifício". Por essa razão, o comércio é definido indiretamente como método inter-relacional e negociação prática, e não somente como atividade econômicoprofissional específica, ainda que aborde diretamente o trato mercantil.

Se por um lado existem palavras que possuem claramente um vínculo semântico com a ação comercial, outras precisam ser inseridas em um contexto particular para ganhar um sentido correlato. Os termos "tributi" e "gabella", que podem ser traduzidos como "impostos/ganhos" e "taxa", aparecem na obra de Leão Africano atrelados ao universo comercial das relações entre povos africanos, já que a ideia de "exploração

225 "Nessa época (anos 1700), a palavra cant e jargón eram empregadas ainda mais amplamente para se referir a 'termos de arte' ou 'termos técnicos' usados por diferentes grupos profissionais. Como demonstrarei no capítulo 1, a expressão 'jargão das escolas' tem sido usada pelo menos desde 1688. Swift, em 1704, sobre 'o cant ou jargão do comércio'...” p. 10. 
econômica" se conecta à receita fiscal de um grupo humano sobre o outro, seja para criar interferência nas atividades comerciais ou mapear as relações de poder entre povos mercantis.

$\mathrm{O}$ aspecto conectivo-mercantil que Leão Africano atribui à parte do seu vocabulário em Della descrittione dell'Africa et delle cose notabli che ivi sono se baseia na transição de usos que esse léxico sofre ao longo do texto. Ao se tomarem palavras que não são automaticamente relacionadas ao comércio vê-se que, quando submetidos a um texto de espionagem comercial e a um contexto de produção de informações e ações negociadas, esses vocábulos acionam um sentido conjuntural, criando noções de instabilidade e incerteza nas relações socioeconômicas entre povos africanos:

\begin{tabular}{|c|c|c|}
\hline $\begin{array}{c}\text { Vocábulo } \\
\text { (noção de incerteza) }\end{array}$ & Original & Trecho \\
\hline Arcabuzeiro & d'archibugieri & $\begin{array}{l}\text { “... levam consigo, por } \\
\text { questões de segurança, } \\
\text { uma companhia de } \\
\text { arcabuzeiros...” }\end{array}$ \\
\hline Assassinos/ladrões & Assassini & $\begin{array}{l}\text { "Os Muslim habitam o } \\
\text { deserto de Masila, o } \\
\text { qual se estende em } \\
\text { direção ao reino de } \\
\text { Buggia. Também são } \\
\text { ladrões e assassinos..." }\end{array}$ \\
\hline Despojo/privação & Spogliati & $\begin{array}{l}\text { “... não sendo suficiente } \\
\text { a defesa, ficam privados } \\
\text { de seus bens, } \\
\text { equipamentos e de suas } \\
\text { vidas." }\end{array}$ \\
\hline Emboscar/emboscada & Imboscati & $\begin{array}{l}\text { "Estão habituadas a } \\
\text { emboscar-se e, quando } \\
\text { passa algum viajante, } \\
\text { encarceram, roubam e } \\
\text { matam." }\end{array}$ \\
\hline
\end{tabular}

Desse modo, ao dizer que os Muslim do deserto de Masila são ladrões e assassinos, ou, ao reforçar a necessidade de proteção de arcabuzeiros no trânsito por certa parte da África, Leão Africano fala também de possíveis prejuízos e riscos que 
fazem do comércio uma atividade incerta nesse espaço de interstício, passível de "emboscadas", "despojos" e "privações".

Da África, Leão Africano espera encontrar a mesma característica geral da água: ao mesmo tempo em que é disforme, insípida e dissolvente, transita e se adapta aos contornos que os olhares, as palavras e as circunstâncias podem conferir. 
Tabela de potenciais produtos comerciais citados por João Leão Africano:

\begin{tabular}{|c|c|c|}
\hline Produtos & Nome científico & Localização \\
\hline Abóbora/cabaça & $\begin{array}{l}\text { Lagenaria } \\
\text { siceraria }\end{array}$ & $\begin{array}{l}\text { Terra dos } \\
\text { Negros }\end{array}$ \\
\hline Abricó/Damasco & Prunus armeniaca & Mauritânia \\
\hline Açafrão & Crocus sativus & Berberia \\
\hline Algália/Almíscar & ---- & $\begin{array}{l}\text { Tunis e } \\
\text { Berberia }\end{array}$ \\
\hline Azeite & --------- & $\begin{array}{l}\text { Mauritânia e } \\
\text { Tunis }\end{array}$ \\
\hline Algodão & $\begin{array}{l}\text { Gossypium } \\
\text { herbaceum }\end{array}$ & $\begin{array}{l}\text { Terra dos } \\
\text { Negros }\end{array}$ \\
\hline Ameixa & Não definido & Mauritânia \\
\hline Antílope/Cervo & Não definido & $\begin{array}{l}\text { Entre Numidia e } \\
\text { Líbia }\end{array}$ \\
\hline Asno selvagem & $\begin{array}{l}\text { Equus } \\
\text { africanus }\end{array}$ & $\begin{array}{l}\text { Entre Numidia e } \\
\text { Líbia }\end{array}$ \\
\hline Avestruz & $\begin{array}{l}\text { Struthio } \\
\text { camelus }\end{array}$ & $\begin{array}{l}\text { Entre Numidia e } \\
\text { Líbia }\end{array}$ \\
\hline Azeitona & Olea europaea & $\begin{array}{l}\text { Mauritânia e } \\
\text { Tunis }\end{array}$ \\
\hline Bronze & ---------- & Tunis \\
\hline Cavalo & Variado & Variado \\
\hline Camelo/dromedário & $\begin{array}{l}\text { Camelus } \\
\text { dromedarius }\end{array}$ & Variado \\
\hline Cebola & Allium cepa & $\begin{array}{l}\text { Terra dos } \\
\text { Negros }\end{array}$ \\
\hline Cereais & Não definido & \\
\hline Cereja & $\begin{array}{l}\text { Prunus } \\
\text { lusitanica }\end{array}$ & Mauritânia \\
\hline Cobre & ---------- & Tunis \\
\hline Dátiles & $\begin{array}{l}\text { Phoenix } \\
\text { dactylifera }\end{array}$ & $\begin{array}{l}\text { Terra dos } \\
\text { Dátiles - } \\
\text { Numidia }\end{array}$ \\
\hline Elefantes & $\begin{array}{l}\text { Loxodonta } \\
\text { africana }\end{array}$ & $\begin{array}{l}\text { Terra dos } \\
\text { Negros }\end{array}$ \\
\hline Escravos & ---------- & Variado \\
\hline Ferro & ---------- & Tunis \\
\hline Figo & $\begin{array}{l}\text { Ficus carica } \\
\text { ou Ficus lyrata }\end{array}$ & Mauritânia \\
\hline Girafa & $\begin{array}{l}\text { Giraffa } \\
\text { camelopardalis }\end{array}$ & $\begin{array}{l}\text { Terra dos } \\
\text { Negros }\end{array}$ \\
\hline Goro & $\begin{array}{l}\text { Cola nítida ou } \\
\text { Cola } \\
\text { acuminata }\end{array}$ & $\begin{array}{l}\text { Terra dos } \\
\text { Negros }\end{array}$ \\
\hline Jujuba & $\begin{array}{l}\text { Ziziphus } \\
\text { mauritiana }\end{array}$ & Mauritânia \\
\hline Maçã & Não definido & Mauritânia \\
\hline Manteiga & ---------- & $\begin{array}{l}\text { Entre Berberia e } \\
\text { Egito }\end{array}$ \\
\hline Marmelo & $\begin{array}{l}\text { Cydonia } \\
\text { oblonga }\end{array}$ & Mauritânia \\
\hline Painço & Panicum & Líbia \\
\hline
\end{tabular}




\begin{tabular}{|l|l|l|}
\hline & miliaceum & \\
\hline Panico & Setaria iltalica & Líbia \\
\hline Pepino & $\begin{array}{l}\text { Cucumis } \\
\text { sativus }\end{array}$ & $\begin{array}{l}\text { Terra dos } \\
\text { Negros }\end{array}$ \\
\hline Pera & Não definido & Mauritânia \\
\hline Pêssego & Não definido & Mauritânia \\
\hline Prata & ---------- & Tunis \\
\hline Romã & Punica granatum & Mauritânia \\
\hline Terra armênia & $\begin{array}{l}\text { Rubrica } \\
\text { Synopica }\end{array}$ & Berberia \\
\hline Trigo & Não definido & $\begin{array}{l}\text { Terra dos } \\
\text { Negros-- } \\
\text { Numidia }\end{array}$ \\
\hline Uva & Não definido & Mauritânia \\
\hline Vinho & ---------- & $\begin{array}{l}\text { Mauritânia - } \\
\text { Rif }\end{array}$ \\
\hline
\end{tabular}




\section{Considerações Finais}

\section{Toda conclusão é feita de ar}

A harmonia do universo foi defendida por filósofos, médicos, astrólogos, matemáticos e até mesmo por viajantes como o equilíbrio entre os quatro elementos da matéria: água, fogo, terra e ar. Os alquimistas afirmavam ainda a existência de um quinto elemento oculto considerado "a alma do mundo" e pertencente ao lugar do metafísico no equilíbrio das matérias.

Essa tese, sobre o capítulo geral da obra Della descrittione dell'Africa et delle cose notabli che ivi sono, de João Leão Africano, pretendeu também harmonizar as partes elementares de sua composição, justificando a existência de seus capítulos e anexos. Talvez os alquimistas do século XVI tenham sido mais felizes nessa tarefa, mas a técnica de misturar metais e elementos químicos para encontrar substâncias metafóricas como a Pedra Filosofal e o Elixir da Longa Vida não permitiu que esses homens chegassem aos resultados esperados. Já a habilidade de misturar e tornar híbridos os contextos formadores do Mediterrâneo moderno (capítulo 1), as racionalidades e incógnitas formadoras da consciência do homem moderno (capítulo 2), os interesses, projetos e linguagens comerciais (capítulo 3), e por fim, a tradução do texto original (anexo 1), gerou um resultado que se espera menos "hermético" nesse momento: a tese aqui apresentada.

Entretanto, sobre os elementos constitutivos desse trabalho paira a mais nobre das partes dessa alquimia: o texto original do chamado "primeiro livro" ou capítulo geral de um dos mais importantes relatos modernos sobre a África, a principal obra de João Leão Africano (anexo 2).

A primeira metade do século XVI, considerada por diversos especialistas como o primórdio do universalismo ocidental e o início da formação de uma economia-mundo dominada pela Europa, precisa urgentemente ser revista. Não se pretende aqui desconsiderar as propostas de autores que, grosso modo, localizaram a formação do sistema capitalista mundial na Europa do século XVI. A discussão que se almeja invocar aqui está relacionada ao mesmo objetivo teórico que permitiu a determinados autores utilizar o conceito de "sistema-mundo" para rever a primeira grande epistemologia eurocêntrica que considerava a modernidade uma propriedade intelectual 
nascida na Europa de homens como Gutenberg, Lutero, Colombo, Vasco da Gama, Petrarca, Maquiavel e Hernán Cortés.

O mote que se coloca a partir de algumas das discussões apresentadas é o de revisão da verticalidade do conceito de Modernidade, entendida como um percurso unilateral que partiu de Portugal, Espanha e Península Itálica, em um primeiro momento, e, depois, de Holanda, Inglaterra e parte da Alemanha. Ao invés da ideia de "percurso", o que se propôs aqui foi a aplicação do termo "fluxo", que implica maior fluidez entre as distintas regiões do mundo que participaram da formação política, econômica, social e cultural do homem moderno.

A pergunta com que Marco Lucchesi abre uma de suas obras sobre o Islã pode representar o "processo alquímico" dessa tese:

"O desafio intelectual deste século reside no fim de uma visão parcial e negativa de que são vítimas as culturas do Oriente, diante de nossa arrogância intelectual. Se o Ocidente é Acidente, e não Destino, se é Parte, e não Todo, como pode outorgar a si mesmo a condição de Leitor ideal do que se passa nas areias do Tchad ou nas mesquitas da Caxemira? ${ }^{226,}$

A discussão sobre a importância de questões reflexivas que conferem validade ao conhecimento, como, por exemplo, o lugar da incerteza e da incógnita no pensamento moderno, exige que a sobrevivência em um ambiente social hostil seja mais forte do que a defesa de qualquer origem cultural e religiosa únicas no homem do século XVI. Um scaltrito como João Leão Africano pode ser a síntese de conhecimentos e reflexões que jamais pertenceram exclusivamente aos europeus cristãos ou aos árabes muçulmanos, formando-se, nas palavras de Numa Broc como "personage de roman qui échappe largement aux classifications traditionelles. ${ }^{227,}$

Por essa razão, a África de Leão Africano é, sobretudo, a parte do continente que ele pôde testemunhar não apenas com seus próprios olhos, mas também com seus próprios ouvidos e pensamentos. O viajante granadino não cria uma África inovadora, e a popularidade de seu relato na Europa não se realiza por suas descrições exclusivamente fantásticas de como os africanos não são como "nós, os europeus", mas propõe uma África sintética que reúne as regiões do continente conhecidas por romanos e árabesislâmicos.

Ainda nas palavras de Broc: "Pourtant L'Afrique de Jean-Léon est loin d'être toute l'Afrique; elle correspond à peu près à l'Africa dês Romains et à l'Ifriqiya de

\footnotetext{
${ }^{226}$ Marco Américo Lucchesi (org.). Caminhos do Islã. Rio de Janeiro: Record, 2002. p. 11.

${ }^{227}$ Numa Broc. La géographie de la Renaissance: 1420 - 1620.Paris: C.T.H.S. Format, 1986. p. 147.
} 
l'Islam, d'Alger à Tombouctou et Du Nil au Maroc. ${ }^{228 ", ~ P a r a ~ f o r m a r ~ e s s a ~ g e o g r a f i a ~ d e ~}$ viagem sobre a África, Leão Africano conta com a harmonia entre a Fortuna, o pudor, a visão algébrica do mundo, e o uso do conceito de "Umrān".

Como o alquimista que desejava a transmutação de metais e o algebrista que transformava incógnitas em resultados matemáticos, Leão Africano traduzia culturalmente suas impressões sobre o mundo nas justas palavras que papas, humanistas, e senhores europeus queriam ouvir, mas que somente poderiam ser ditas ou atribuídas a quem já foi tão bárbaro como a barbárie descrita, e que precisava ser rotineiramente absolvido da acusação de ser o que sempre foi.

Entretanto, se Nicolas Flamel, em pleno século XIV, fracassou na exaustiva tarefa de provar empiricamente que qualquer metal podia ser transformado em ouro, Leão Africano, como um alquimista da linguagem, mostrou que os grãos, frutos e escravos da África podiam ser transformados em riquezas comerciais tão áureas quanto os metais das Américas e as especiarias da Ásia.

É claro que esse processo de manipulação de elementos e vidas em favor do comércio se deu de forma retórica em seu texto, e um dos passos fundamentais para se entenderem as palavras de Leão Africano é o reconhecimento do caráter violento e não apenas retórico de qualquer reação alquímica, ou melhor, de qualquer experiência colonial.

O fim de al-Andaluz foi o começo de tudo...

229 مع الـ سدلامة الأذ دل س

Arrivederci Africa...

Adeus USP...

${ }^{228}$ Idem, p. 148.

${ }^{229}$ Em árabe, "Adeus, al-Andaluz". 


\section{BIBLIOGRAFIA:}

ABDALA JUNIOR, Benjamim (Org.). Margens da cultura: mestiçagem, hibridismo e outras misturas. São Paulo: Boitempo, 2004.

AHMED, Aijaz. Linhagens do presente. São Paulo: Boitempo, 2002.

ARANOVICH. Patrícia Fontoura. Di Fortuna e a Fortuna em Maquiavel.Cadernos de Ética e Filosofia Política. No. 18. São Paulo, $1^{\circ}$. semestre de 2011.

ARAÚJO, Richard Max de. Ibn Khaldun: a ideia de decadência dos Estados. São Paulo: Humanitas, 2007.

ARENDT, Hanna. Sobre a revolução. São Paulo: Companhia das Letras, 2011.

ARNAUT, Cezar e BERNARDO, Leandro F. Virtù e Fortuna no pensamento de Maquiavel. Acta Scientiarum, Maringá, v. 24, n. 1, fev. 2002.

ATTIE FILHO, Miguel. Falsafa: a filosofia entre os árabes - uma herança esquecida. São Paulo: Palas Athena, 2002.

AURELL, Jaume e PUIGARNAU, Alfons. A cultura do mercador na Barcelona do século XV. São Paulo: Imstituto Brasileiro de Filosofia e Ciência "Raimundo Lúlio" (Ramon Llul), 2008.

BARTELS, Emily C. Othelo and Africa:Postcolonialism Reconsidered. The William and Mary Quarterly, 3ª. ser. Vol. 54, No. 1. Jan. 1997

BELL-SANTOS, Cynthia Ann. et ali. (orgs.). Tradução e cultura. Rio de Janeiro: 7 letras, 2011.

BERBARA, Maria. Renascimento italiano: ensaios e traduções. Rio de Janeiro: Nau Editora, 2010. 
BERMAN, Antoine. A Tradução e a letra: ou o albergue do longínquo. Rio de Janeiro: 7 letras, 2006.

BHABHA, Homi K. O local da cultura. Belo Horizonte: Editora UFMG, 2010.

BIGNOTTO, Newton. As aventuras da virtude: as ideias republicanas na França do século XVIII. São Paulo: Companhia das Letras, 2010.

BISSIO, Beatriz. O mundo falava árabe: a civilização árabe-islâmica clássica através da obra de Ibn Khaldun e Ibn Battuta. Rio de Janeiro: Civilização Brasileira, 2012.

BLACK, Crofton. Leo Africanus's "Descrittione dell'Africa" and its sixteenthcentury translations. Journal of the Warburg and Courtauld Institutes. Vol. 65 (2002).

BOISSEVAIN, Jeremy. Towards a Social Anthropology of the Mediterranean.

Current Anthropology, Vol. 20. No. 1, 1979.

BORGES, Marta da Graça Burnay Pereira de Almeida. Um estreito globalizado: a luta por Ormuz (1622) e a globalização das relações internacionais no período moderno. Dissertação de Mestrado. Instituto Superior de Ciências do trabalho e da Empresa. Lisboa, 2008.

BOUHDIBA, Abdelwahab. A sexualidade no Islã. São Paulo: Globo, 2006.

BOXER, Charles R. A Igreja militante e a expansão ibérica:1440-1770. São Paulo: Companhia das Letras, 2007.

BRAUDEL, Fernand. Civilização material, economia e capitalismo: séculos XV-XVIII. São Paulo: Martins Fontes, 2009. 3 Vls.

BRAUDEL, Fernand. El Mediterráneo y el Mundo Mediterráneo en la Época de Felipe II. Tomo II. Cidade do México: Fondo de Cultura Económica, s/d. 
BROC, Numa. La géographie de la Renaissance: 1420 - 1620.Paris: C.T.H.S. Format, 1986.

BROTTON, Jerry. O bazar do Renascimento: da rota da seda a Michelangelo. São Paulo: Grua, 2009.

BURCKHARDT, Jacob. A cultura do Renascimento na Itália: um ensaio. Brasília: Ed.Universidade de Brasília, 1991.

BURKE, Peter e PORTER, Roy (org.) Línguas e jargões: contribuições para uma história social da linguagem. São Paulo: Editora UNESP, 1997.

BURKE, Peter e HSIA, R. Po-chia. A tradução cultural nos primórdios da Europa Moderna. São Paulo: Editora UNESP, 2008.

CANTIMORI, Delio. Humanismo y religiones en el Renacimiento. Barcelona: Edicions $62,1984$.

CAVALCANTE, Berenice et. al. Modernas tradições: percursos da cultura ocidental séculos XV - XVII. Rio de Janeiro: Access, 2002.

CHEBEL, Malek. El espíritu de serrallo: estructuras y variaciones de la sexualidad magrebí. Barcelona: Bellaterra, 2000.

CLARK, Laurie E. et SUNDERLAND, Terry C. H. Forest Products of Central Africa: State of knowledge. Technical Paper no. 122. Maio, 2004.

COQUERY - VIDROVITCH, Catherine. A descoberta de África. Lisboa: edições 70, 2004.

CRISTÓVÃO, Fernando. Condicionantes culturais da literatura de viagens: estudos e bibliografias. Coimbra: Almedina, 2002. 
DAVIS, John. People of the Mediterranean: An Essay in Comparative Social Anthropology. Londres: Routledge, 1977.

DAVIS, Natalie Zemon. Trickster Travels: A Sixteenth-Century Muslim between Worlds. New York: Hill and Wang, 2006.

DE GRAZIA, Sebastian. Maquiavel no Inferno. São Paulo: Companhia das Letras, 1993.

DI BIASE, Carmine G. (Ed.). Travel and Translation in the Early Modern Period. Amsterdã: Rodopi, 2006.

DOMINIQUE. Paule Charles (trad.). Voyageurs arabes : Ibn Fadlan, Ibn Jubayr, Ibn Battuta et un auteur anonyme. Paris : Éditions Gallimard, 1995.

DUBE, Saurabh et ali (coord). Modernidades coloniales: otros pasados, historias presentes. México D.F. El Colegio de Mexico, Centro de Estudios de Asia y África, 2004.

DUBOIS, Claude-Gilbert. O imaginário da Renascença. Brasilia: Editora UNB, 1995.

FALCON, Francisco e RODRIGUES, Antonio Edmilson. A formação do mundo moderno: a construção do Ocidente dos séculos XIV ao XVIII. Rio de Janeiro: Elsevier, 2006.

FANJUL, Serafín (trad.). Descripción General del África y de las Cosas Peregrinas que allí hay. Granada: Fundación El Legado Andalusí. 2004.

FERNÁNDEZ, Luis Gil. El Imperio luso-español y la Persia safávida. Tomo I (15821605). Madrid: Fundación Universitaria Española, 2006.

GARCÍA, Luz Gómez. Diccionario de Islam e Islamismo. Madri: Espasa Calpe, 2009. 
GARIN, Eugenio. Ciência e vida civil no Renascimento italiano. São Paulo: Editora UNESP, 1996.

GARIN, Eugenio. El Renascimiento italiano. Barcelona: Ariel, 2012.

GARIN, Eugenio. O homem renascentista. Lisboa: Editorial Presença, 1991.

GILMORE, David D. Anthropology of the Mediterranean Area. Annual Review of Anthropology. Volume 11, 1982.

GINZBURG, Carlo. Mitos, emblemas, sinais: morfologia e história. São Paulo: Companhia das Letras, 1989.

GINZBURG, Carlo. O fio e os rastros: verdadeiro, falso, fictício. São Paulo: Companhia das. Letras, 2007.

GINZBURG, Carlo. O queijo e os vermes: o cotidiano e as idéias de um moleiro perseguido pela inquisição. São Paulo: Ed. Companhia das Letras, 1987.

GOMES, Plínio Freire Gomes. Volta ao mundo por ouvir-dizer: redes de informação e a cultura geográfica do Renascimento. Anais do Museu Paulista, São Paulo, v. 17, n. 1, Junho 2009.

GOODY, Jack. O roubo da História: como os europeus se apropriaram das ideais e invenções do Oriente. São Paulo: Editora Contexto, 2008.

GOODY, Jack. Renascimentos: um ou muitos? São Paulo: Editora UNESP, 2011.

GUZMÁN, Roberto Marín. Sociedad, política y protesta popular en la España Musulmana. San José: Editorial UCR, 2006.

HAUSER, Arnold. Maneirismo: a crise da Renascença e o surgimento da arte moderna. São Paulo: Perspectiva: Universidade de São Paulo, 1976. 
HELLER, Agnes. O homem do Renascimento. Lisboa: Editorial Presença, 1982.

HERMANN, Jacqueline. No reino do desejado: a construção do sebastianismo em Portugal - séculos XVI e XVII. São Paulo: Cia das Letras, 1998.

HERNÁNDEZ, Miguel Cruz. La Filosofía Árabe. Madri: Revista de Occidente. s/d.

HALE, John (ed.) Dicionário do Renascimento italiano. Rio de Janeiro: Jorge Zahar Editor, 1988.

HUIZINGA, Johan. O outono da Idade Média. São Paulo: Cosac Naify, 2010.

al-JABRI. Mohammed Abed. Introdução à crítica da razão árabe. São Paulo: Editora UNESP, 2009.

KEDDIE, Nikki R. Las raíces del Iran Moderno. Barcelona: Belacqua, 2006.

KIEFER, Frederick. The conflation of Fortuna and Occasio in Renaissance thought and iconography. The Journal of Medieval and Renaissance Studies 9 (1979).

KOSELLECK, Reinhart. Futuro pasado: contribuição à semántica dos tempos históricos. Rio de Janeiro: PUC-Rio: Contraponto, 2006.

KUMRULAR, Ozlem. Las relaciones entre el Imperio otomano y la monarquía católica entre los años 1520-1535 y el papel de los Estados satélites. Istambul: Editorial Isis. 2003.

KUMRULAR, Ozlem. El duelo entre Carlos V y Soliman El Magnífico (1520-1535). Istambul: Editorial Isis. 2003.

LACOSTE, Yves. Ibn Khaldoun : naissance de l'histoire passé du tiers monde. Paris : François Maspero, 1973. 
LESTIENNE, Rémy. O acaso criador: o poder criativo do acaso. São Paulo: EDUSP, 2008.

LESTRINGANT, Frank. A oficina do cosmógrafo ou a imagem do mundo no Renascimento. Rio de Janeiro: Civilização Brasileira, 2009.

Livro das Mil e uma noites. Tradução: Mamede Mustafá Jarouche. Editora: Biblioteca Azul. 2012. 4 volumes.

LOVEJOY, Paul.E. Kola in the history of West Africa. Cahiers d'études africaines, v. 20, n. 77 , p. $97-134,1980$.

LUCCHESI, Marco Américo (org.). Caminhos do Islã. Rio de Janeiro: Record, 2002.

MAALOUF, Amin. Entre dois mundos: amores e aventuras de Leão, o africano. São Paulo: Best Seller, s/d.

MASONEN, Pekka. Leo Africanus: The Man with Many Names. Al-AndaluzMagreb. 2000/01, v. 1, n. 8-9.

MATA, Maria Jesus Rubiera. Carlos V, los moriscos y El Islam. Madrid: Editora Museo del Prado, 2000.

MENZIES, Gavin. 1434: o ano em que uma magnífica frota chinesa velejou para a Itália e deu início ao Renascimento. Rio de Janeiro: Bertrand Brasil, 2010.

MICHELET, Jules. A agonia da Idade Média. São Paulo: EDUC: Imaginário, 1992

MIGNOLO, Walter D. "El lado más oscuro del Renacimiento", Universitas Humanística, No. 67. (janeiro-junho 2009).

MIGNOLO, Walter D. The Darker Side of Renaissance: Literacy, Territoriality \& Colonization. Michigan, University of Michigan Press, 2006. 2a. Ediçao. 
MLODINOW, Leonard. O andar do bêbado: como o acaso determina nossas vidas. Rio de Janeiro: Zahar, 2009.

Charles Nauert, "Heinrich Cornelius Agrippa von Nettesheim", The Stanford Encyclopedia of Philosophy (Summer 2011 Edition), Edward N. Zalta (ed.). http://plato.stanford.edu/archives/sum2011/entries/agrippa-nettesheim

NIANE, Djibril Tamsin (ed.). História Geral da África IV: África dos séculos XIII ao XVI. UNESCO/MEC - Brasil, 2010.

PANOFSKY, Erwin. Estudos de iconologia: temas humanísticos na arte do Renascimento. Lisboa: Editorial Estampa, 1995.

PATER, Walter. The Renaissance. Nova Iorque: The Modern Library, s/d.

PERISTIANY, J. G. (org.). Honra e Vergonha: valores das sociedades mediterrâneas. Lisboa: Fundação Calouste Gulbenkian, 1971.

PICCHIO, Luciana Stegagno. Portugal e portugueses no livro "Navigationi” de G.B. Ramusio. IV Reunião Internacional de História da Náutica e da Hidrografia, SagresLagos, julho 1983.

PINTO, Paulo Gabriel Hilu da Rocha. Islã: religião e civilização - uma abordagem antropológica. Aparecida: Santuário, 2010.

PITT-RIVERS, J. A. Un pueblo de la Sierra. Madri: Alianza Editorial, 1989.

POUILLON, François et ali (org.). Léon L`Africain. Paris: Karthala, 2009.

PRATT, Mary Louise. Os olhos do império: relatos de viagem e transculturação. Bauru: EDUSC, 1999.

RABICHEV, Renata. The Mediterranean concepts of honour and shame as seen in the depiction of the biblical women. Religion and Theology. Vol 3/1. 1996. 
http://www.unisa.ac.za/default.asp?Cmd=ViewContent\&ContentID=7356

RAMUSIO, Giovanni Battista. Il Viaggio di Giovan Leone e Le Navigazioni V1 (1837).

RASHID, Mahdi Mohamed-Saleh. Fundamentos y Análisis del pensamiento histórico, social y político de Ibn Jaldún. Tese de doutorado. Universidad Pontifica de Salamanca, 2009.

REDONDO, Manuel Santos. El cambista y su mujer: de la Escolástica a la contabilidad. Documento de trabalho ou informe técnico. Biblioteca Universidad Complutense de Madrid.

http://eprints.ucm.es/6724/

RI JUNIOR, Arno Dal e ORO, Ari Pedro (orgs.). Islamismo e Humanismo latino: Diálogos e desafios. Petrópolis: Editora Vozes, 2004.

RIVERA Rubén Soto. Los pétreos biblionautas del Kairós salmantino. Acceso: Revista Puertorriqueña de Bibliotecología y Documentación. Año/vol. 5, número 001. Sociedad de Bibliotecarios de Puerto Rico. San Juan, Puerto Rico.

ROONEY, Anne. A História da matemática: desde a criação das pirâmides até a exploração do infinito. São Paulo: M.Books, 2012.

ROQUE, Tatiana. História da matemática: uma visão crítica, desfazendo mitos e lendas. Rio de Janeiro: Zahar, 2012.

SAID, Edward W. Orientalismo: O Oriente como invenção do Ocidente. São Paulo: Cia das Letras, 2001. 3 a. reimpressão.

SALA, Juan Pedro Monferrer e GÓMEZ, María Dolores Rodríguez. (eds). Entre Oriente y Occidente: ciudades y viajeros en la Edad Media. Granada: Universidad de Granada, 2005. 
SANTACRUZ, Víctor Sanz. Juan de Segovia y Nicolás de Cusa frente al Islam: su comprensión intelectualista de la fe cristiana. Anuario de Historia de la Iglesia (2007).

SANTOS, Boaventura de Sousa e MENESES, Maria Paula (orgs.).Epistemologias do Sul. São Paulo: Cortez editora, 2010.

SANTOS, Carlos Alberto Ávila. Espelhos e reflexos: uso e representação em obras artísticas. X Seminário de História da Arte. Vol. 1. No. 1. 2011.

SKINNER, Quentin. As fundações do pensamento político moderno. São Paulo: Companhia das Letras, 1996.

SANZ, José Luis Martínez. Al-Ándalus: lós árabes en España. Madri: Edimat, s/d.

SCHMITT, Carl. El nomos de la tierra en el derecho de gentes del "Jus publicum europaeum". Madri: Centro de Estudios Constitucionales, 1979.

SCHMITT, Carl. Tierra y mar: una reflexión sobre la historia universal. Madri: Editorial Trotta, 2007.

SILVA, Alberto da Costa e. A enxada e a lança: a África antes dos portugueses. Rio de Janeiro: Nova Fronteira, 2006. $3^{\text {a }}$. Edição revista e ampliada.

SILVA, Alberto da Costa e. Imagens da África. São Paulo: Penguin, 2012.

SILVA, Alberto da Costa e. A manilha e o libambo: a África e a escravidão, de 1500 a 1700. Rio de Janeiro: Nova Fronteira, 2002.

STARN, Randolph. A Postmodern Renaissance? Renaissance Quarterly, Vol. 60, No. 1 (Spring 2007), pp. 1-24

SUBRAHMANYAM, Sanjay. On World Historians in the Sixteenth Century," Representations 91 (2005): 26-57 
TEMPORAL, Jean. (trad.). Historiale Description de l'Afrique, tierce partie du monde. Lion, 1556.

http://gallica.bnf.fr/ark:/12148/bpt6k1044206/f3.image.r=description\%20afrique.langF $\underline{\mathrm{R}}$

TOSCANO, Fabio. A fórmula secreta: Tartaglia, Cardano e o duelo matemático que inflamou a Itália da Renascença. Campinas: Editora UNICAMP, 2012.

TRAXINO, Mario. La Bataglia di Ravenna (11 Aprile 1512).

http://www.mariotraxino.it/la\%20battaglia\%20di\%20Ravenna.pdf

TEIXEIRA, Felipe Charbel. Timoneiros: retórica, prudência e história em Maquiavel e Guicciardini. Campinas: Editora UNICAMP, 2010.

TREVOR-ROPPER, H.R. Religião, Reforma e transformação social. Lisboa: Editorial Presença/Martins Fontes, 1981.

VAQUERO, Carlos Pérez. El cambista y su mujer, de Quentin Massys. Revista Contabilizarte. IV Trimestre, 2010.

WATKINS, Ronald J. Por mares nunca dantes navegados: como Vasco da Gama abriu caminho para o Oriente. Rio de Janeiro: José Olympio, 2011.

WHITNEY, Lois. Did Shakespeare know Leo Africanus? PMLA, Vol. 37, no. 3 (set. 1922)

WISSENBACH, Maria Cristina Cortez. Cirurgiões do Atlântico Sul - conhecimento médico e terapêutica nos circuitos do tráfico e da escravidão (séculos XVII - XIX). Anais do XVII Encontro Regional de História - O lugar da História. ANPUH/SP. UNICAMP. Campinas, 6 a 10 de setembro de 2004.

WISSENBACH, Maria Cristina Cortez. Narrativas de viagem, comércio de escravos e saberes médico-terapêuticos entre cirurgiões embarcadiços (séculos XVII - XIX). $8^{\circ}$ Congreso Ibérico de Estudios Africanos: Encounters of Medicine in Africa between the 
local and the global: historical and contemporary perspectives. Universidad Autónoma de Madrid. Madri, 14 a 16 de junho de 2012.

YABRI, Mohamed Ábed. El legado filosófico árabe: Alfarabi, Avicena, Avempace, Averroes, Abenjaldún - Lecturas contemporáneas. Madri: Editorial Trotta, 2006. $2^{\mathrm{a}}$. Edição

ZUBILlAGA, Tereza. Un exilado granadino descubre África: León el Africano (15041520). (IN) Dossiê "Exploradores españoles olvidados de África". Sociedad Geográfica Española. 2001. http://www.sge.org/exploraciones-y-expediciones/galeria-deexploradores/i-los-primeros-viajes/leon-el-africano-1504-1520. Acesso em 22 de novembro de 2012. 


\section{ANEXO I: \\ TRADUÇAO DO PRIMEIRO LIVRO DE DELLA DESCRITTIONE DELL`AFRICA ET DELLE COSE NOTABLI CHE IVI SONO}

\section{Por que essa parte do mundo é chamada de África.}

A África é chamada em língua árabe de Ifriquiyya*, do verbo faraca* que, na linguagem falada dos árabes, significa "partida" ou "dividida". Existem duas opiniões sobre essa denominação, uma delas leva em consideração que essa parte da terra está separada da Europa pelo Mar Mediterrâneo e da Ásia pelo rio Nilo. E a outra opinião é que esse nome vem de "Ifrico", rei da Arábia Feliz ${ }^{230}$, que foi o primeiro que chegou a habitá-la. Ao ser derrotado em batalha, esse rei foi expulso pelos assírios, e não podendo voltar com seu exército para seu reino, atravessou rapidamente o Nilo e, conduzindo seus passos em direção ao poente, não parou até chegar aos arredores de Cartago. A partir disso, é que se explica porque os árabes entendam por África apenas a região de Cartago, enquanto que à sua totalidade tomam somente pela parte ocidental $\left(\right.$ Magreb $\left.^{231}\right)$.

\section{Os limites da África.}

Segundo os próprios africanos (quero dizer, os bem versados em letras e cosmografia), a África começa a partir dos cursos d’água do lago Gaoga, ou seja, à meio-dia ${ }^{232}$, termina em direção à leste no rio Nilo e se estende até o norte aos pés do Egito, nomeadamente, onde o Nilo encontra o Mar Mediterrâneo. Pelo lado setentrional está também a entrada do Nilo no referido mar, alargando-se pelo poente até o Estreito das Colunas de Hércules. Por esse lado do poente corre através desse Estreito junto ao Mar Oceana ${ }^{233}$ até Noun $^{234}$, última cidade da Líbia a ele somada. e à meio-dia começa

\footnotetext{
${ }^{230}$ Do latim: Arabia Felix; a parte considerada mais fértil da Península Arábica. Corresponde atualmente ao território do sudoeste da península, atuais Omã e Iêmen.

${ }^{231}$ Do árabe: al-magreb (الدغرب), que significa "poente". Existem diversas aplicações contemporâneas para o termo. O vocábulo pode ser usado para definir em árabe, a idéia de "Ocidente"; ou mesmo para nomear o Reino do Marrocos. Para Leão Africano, o termo faz menção à porção do extremo geográfico ocidental do mundo árabe-islâmico, entre os atuais territórios da Tunísia em direção ao Marrocos.

${ }^{232}$ De acordo com o vocabulário de orientação astronômica, "ao meio-dia" solar é quando o Sol encontrase ao sul do observador.

${ }^{233}$ Oceano Atlântico.

${ }^{234}$ Cidade imaginada por Leão Africano, que a confunde com o Cabo Noun, na costa sul do Marrocos.
} 
também pela cidade de Noun e se estende ao longo do Oceano que, até os desertos de Gaoga, rodeia e abraça toda a África.

\section{A divisão da África.}

Com base em nossos escritores, a África está dividida em quatro partes: a Berberia, a Numidia, a Líbia e a Terra dos Negros.

A Berberia começa pelo Oriente nos montes chamados de Meies, que é a última ponta do Atlas, a cerca de trezentas milhas de Alexandria e, pela parte setentrional, termina no Mar Mediterrâneo, alargando-se desde o início de Meies até o Estreito das supracitadas Colunas de Hércules. Pela parte do poente, seu término começa no Estreito y nas margens do Mar Oceano até os últimos sopés do Atlas, onde sua porção ocidental tem início a partir do Oceano, próximo ao lugar em que se encontra a cidade de Messa. À meio-dia termina em direção ao monte Atlante, y a cara do referido monte que olha para o Mar Mediterrâneo é a mais nobre parte da África e nela estão as cidades dos homens brancos, que por senso comum e leis se governam.

A segunda região foi chamada Numidia pelos latinos e pelos árabes de "Bilad alJarid" 235 ", que significa "terra onde nascem as tamareiras". Pela parte do levante, a região começa por Eloachet ${ }^{236}$, cidade distante cerca de cem milhas do Egito, e se estende ao poente até a referida Noun sobre o Mar Oceana, e em direção ao Norte, termina no monte Atlas, especificamente, em sua encosta que olha para o Sul, enquanto que à meio-dia finda e margeia a areia do deserto líbio. Os árabes chamam-na usualmente de "as terras das tâmaras" com apenas esse nome por concentrar essas frutas nessa região.

A terceira região, que em língua latina é chamada de Líbia e em árabe de Sarra $^{237}$, nomeadamente, deserto; tem início na costa oriental do Nilo, para os limites de

\footnotetext{
${ }^{235}$ Região semidesértica próxima ao norte do deserto do Saara, localizada no sudoeste da atual Tunísia. Compreende também uma parte dos atuais territórios da Líbia e da Argélia. Ao longo da obra, Leao Africano utiliza a termo transliterado "Biledulgerid". Nesta tradução, para melhor situá-lo, substituirei para a forma árabe transliterada "Bilad al-Jarid".

${ }^{236}$ Região da atual distrito líbio de al-Wahat (الدواحات).

${ }^{237}$ Corruptela da palavra árabe as-Sahra (ال صحراء), que significa "deserto". O uso cotidiano fez com que a palavra fosse utilizada para designar o deserto norte - africano que abarca parte dos atuais territórios de Argélia, Burkina Faso, Chade, Egito, Líbia Marrocos, Saara Ocidental, Mauritânia, Mali Níger, Senegal Sudão e Tunísia.
} 
Eloachet; e se estende pelo Ocidente até o Mar Oceana. E, entretanto, do Norte adjacente à Numidia, a terra das tâmaras. Finalmente, em seu extremo meridional limita-se com a Terra dos Negros, para Leste do reino de Gaoga, e surge ao poente até o reino de Gualata ${ }^{238}$, que se estende em direção ao Mar Oceana.

A quarta região, a Terra dos Negros, começa, partindo do Oriente, pelo reino de Gaoga, segue a Ocidente até Gualata, e se alarga ao Norte até os desertos da Líbia, acabando à meio-dia no Mar Oceana; lugares desconhecidos por nós, mas que temos muitas notícias por causa dos mercadores que chegam ao reino de Tombuctú. Em metade da Terra dos Negros corre o rio chamado Níger; este nasce em um deserto chamado Seu, saindo de um grande lago, e se dirige para o poente até que desemboca no Mar Oceana. E, segundo afirmam nossos cosmógrafos, o Níger é um braço do Nilo, o qual se perde de vista por ficar subterrâneo e logo volta formando o citado lago. Alguns dizem que esse rio brota do lado Ocidental por certas montanhas e que, correndo para Oriente, se converte em lago, mas isso não é verdade, posto que nós navegamos desde o reino de Tombuctú à Leste, seguindo o curso d'água até o reino de Ghinéa ${ }^{239}$ e até o reino de $\mathrm{Melli}^{240}$, ambos a Oeste de Tombutto ${ }^{241}$. Os reinos mais bonitos dos negros localizam-se em torno do rio Níger e aconselhemos que, como os supracitados cosmógrafos mostram, uma parte da Terra dos Negros, atravessada pelo Nilo no seu curso ocidental, alarga-se em direção ao levante até o Mar Índico, e por alguns lugares mais a Norte beira também o Mar Vermelho; ou seja, a parte recai sobre o Estreito da Arábia Feliz $^{242}$ não está considerada como uma parte da África, por muitas razões que se detalham em longos tratados. Os latinos chamam-na de Etiópia e dela advêm certos frades com suas caras marcadas a fogo e se vêem por todas as partes da Europa, especialmente em Roma ${ }^{243}$. Esse país é comandado por um chefe parecido a um Imperador o qual os italianos chamam de Preste João. A parte maior de tal região está habitada por cristãos, ainda que um Senhor muçulmano seja dono de grandes possessões.

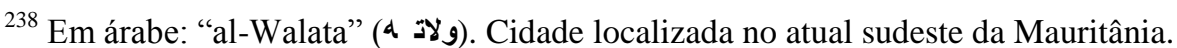

${ }^{239}$ Possivelmente, a cidade de Djenné, localizada no centro do atual território do Mali.

${ }^{240}$ Atual território do Mali.

${ }^{241}$ Tombuctú, Mali. Serafin Fanjul afirma que essa passagem se trata de um conjunto de descrições erradas de Leao Africano, que jamais fez realmente essa viagem, e fala por informações de outras pessoas que recolheu em suas viagens. Ver Serafin Fanjul. Descripción general del África y de las cosas peregrinas que allí hay. COMPLETAR REFERENCIA!!!

242 Estreito de Bab al-Mandab (بـ اب الدم ندب) , separa a Ásia (Iêmen) da África (Djibuti).

${ }^{243}$ Possível menção a sacerdotes cristãos etíopes.
} 


\section{Divisões e reinos dessas quatro partes da África.}

A Berberia se divide em quatro reinos. O primeiro é o reino do Marrocos ${ }^{244}$, que por sua vez, se divide em sete regiões, a saber, Ea, Sus Guzzula Marrocos, Duccala, Azcora e Tedle. O segundo reino é o Fessa ${ }^{245}$, com outras tantas regiões submetidas a ele, como são Temeane, o território de Fez, Azgar, Elabat, Errifi, Garet, Elcauz. O de Telensin, é o terceiro reino, com as regiões dos montes, Tenez e Elgezair ${ }^{246}$. O quarto reino é o de Tunis, ao qual estão submetidos as quatro regiões de Buggia, Costantina, Tripoli da Berberia ${ }^{247}$, Ezzab, que é uma parte da Numidia. A região de Buggia sempre esteve em disputa, e algumas vezes foi anexada ao reino de Tunis e outra vez ao de Telensin. É verdade que em nossos dias converteu-se em reino autônomo até que Pedro Navarro, em nome de Fernando, Rei da Espanha, tomou sua cidade principal.

\section{Divisão da Numidia, ou seja, da terra onde nascem as tâmaras.}

Sendo esta parte da África menos nobre que as outras, nossos cosmógrafos não deram um titulo especifico ao reino. As populações encontram-se mais distantes uma das outras; por exemplo, Tesset, cidade da Numidia, que conta com cerca de quatrocentas famílias, mas está a aproximadamente trezentas milhas de qualquer outra população, e por isso não merece o título de reino.

Eu detalharei os nomes das terras habitadas. Alguns deles são semelhantes a outros como o estado de Segelmesse, que está na parte da Numidia que corresponde à Mauritânia, e o estado de Zeb, limítrofe ao reino de Buggia e "Bilad al-Jarid", que se estende em direção ao reino de Tunis.

Agora, reservo-me ao direito de contar sobre a segunda parte da África. Começando pelo lado ocidental, os nomoes são estes: Tesset, Guaden, Ifren, Acca, Dara, Tebelbet, Todga, Fercale, Segelmesse, Benigomi, Feghig, Teguat, Tsabit,

\footnotetext{
${ }^{244}$ Leão Africano chama de "Marrocos", apenas as terras da atual cidade de Marrakesh.

${ }^{245}$ Atual cidade de Fez.

${ }^{246}$ Tenez e Elgezair são, possivelmente, regiões que atualmente compreendem o território da Argélia. Em árabe, a Argélia é conhecida como "al-Jazair" (ال جزائ ر)

247 “Trípoli da Berberia" é uma referência à atual cidade de Trípoli, capital da Líbia. Leão Africano utiliza essa nomenclatura para diferencia a Trípoli africana da cidade de Trípoli, no litoral do Líbano.
} 
Tegorarin, Mesab, Teggort, Guarghela. Zeb é uma província e contém cinco cidades, que são Pescara, Elbourgiu, Nefta, Taolacca e Deusen. "Bilad al-Jarid" senhoreia outras tantas cidades: Teozar, Cafeza, Nefreoa, Elcama e Calbiz. Depois desta, em direção ao levante, está a ilhade Gerbe, Garion, Messellata, Met-strata, Teoirraga, Gademis, Fizzan, Augela, Birdeva, Eloachet. Esses são os nomes dos lugares mais famosos da Líbia, partindo do mar Oceana, desde Ocidente como dissemos, e terminando nos limites do Nilo.

\section{Divisão dos desertos entre Numidia e a Terra dos Negros.}

Estes desertos abaixo de nós não receberam nome algum. Entretanto, dividem-se em cinco partes e cada uma é conhecida segundo o nome do povo que a habita e ali faz a sua vida. São númidas, divididos, por sua vez, em cinco partes: Zanaga, Guanziga, Terga, Lemta e Berdeoa. Possuem alguns campos, que são nomeados de acordo com sua boa ou má condição, como Azaoad, deserto assim chamado pela esterilidade e escorias que ali abundam, e Air, também deserto, mas nomeado pela condição boa e amena de seu ar.

\section{Divisão da Terra dos Negros por seus reinos.}

Esta Terra dos Negros está também dividida em muitos reinos, ainda que alguns continuem desconhecidos e apartados de nosso comércio. Falarei, portanto, de onde passei e tive longa experiência, assim como de outros caminhos por onde partiram mercadores que comerciaram suas mercadorias no país em que me encontrava e me abasteceram de boas informações. Não escondo o fato de que estive em quinze reinos da Terra dos Negros e que existem três vezes mais deles em que não estive, cada um, bem conhecido e próximo aos que visitei. Os nomes desses reinos, de Ocidente a Oriente e à meio-dia são estes: Gualata, Ghinea, Melli, Tombutto, Gago, Guber, Agadez, Cano, Casena, Zegzeg, Zanfara, Guangara, Borno, Gaoga e Nube, quinze reinos, em sua maioria nas margens do rio Níger; e através deles os comerciantes fazem seu caminho de Gualata para chegar ao Cairo ${ }^{248}$. O caminho é longo, mas muito seguro. Estes reinos estão separados uns dos outros por um deserto de areia, ou então pelo rio Níger. E

\footnotetext{
${ }^{248}$ Aqui, Leão Africano se confunde. Ele se refere ao Níger como se estivesse integrado ao Nilo.
} 
sabendo que outrora, cada um dos ditos reinos eram possessões de um único senhor, hoje, os quinze reinos estão submetidos ao domínio de três reis: o de Tombutto, e este possui a maior parte; o rei de Borno, dono da menor, enquanto que a terceira está em poder do rei de Gaoga. De fato, o senhor de Duccala domina também um estado pequeno. Limitam-se com estes reinos à meio-dia, muitos outros, que são os de Bito, Temiam, Dauma, Medra, Goran: cujos senhores e habitantes são ricos e assaz práticos, administram a justiça e se governam bem, enquanto que os outros são de pior condição que as bestas.

\section{Populações da África e significado da voz Barbar.}

Às palavras dos cosmógrafos e escritores da história, a África estava antigamente desabitada por toda parte, menos a Terra dos Negros. Dá-se por coisa certa que a Berberia e a Numidia estiveram privadas de população por muitos séculos. Os que hoje as habitam, sendo brancos, são chamados de Barbar, nome derivado, segundo dizem alguns, de barbara, que em sua própria língua significa, como em italiano "murmurar": ocorre portanto que a fala dos africanos é para os árabes como a fala dos animais, que de nenhum sotaque é composto, senão de gritos. Outros dizem que Barbar é uma palavra repetida, já que bar na linguagem dos árabes quer dizer "deserto", e contam que, nos tempos em que o rei Africo foi vencido pelos assírios, ou pelos etíopes, sendo ainda perseguido por seus inimigos ao fugir para o Egito e não encontrando maneiras de como se defender, pediu a suas gentes que o aconselhassem sobre qual partido tomar para salvar-se, pergunta que não foi respondida senão aos gritos de: " $E l$ bar bar"; ou seja, "ao deserto, ao deserto", querendo assim dizer-lhe que não se conhecia outro remédio senão, passando o Nilo, reduzir seus inimigos no deserto da África. Esse raciocínio concorda com aqueles que afirmam que a origem dos africanos se assenta nos povos da Arábia Feliz.

\section{Origem dos africanos.}

Sobre a origem dos africanos, são muitas as historias e bem diferentes entre si. Alguns dizem que descendem dos palestinos, quando estes, expulsos antigamente pelos assírios, fugiram até a África e, como a encontraram boa e frutífera, nela ficaram. 
Outros são da opinião de que a origem dos africanos vem dos sabeus, povo da Arábia Feliz, também em fuga de suas terras ante ataque de assírios ou etíopes. Outros afrimam que os africanos foram habitantes de algumas partes da Ásia, segundo eles, envolvidos em guerras com certos inimigos chegaram em sua fuga até a Grécia, que nessa época não estava habitada e, assediados por tais inimigos, foram obrigados a atravessar o "Mar della Morea ${ }^{249, "}$ e, chegando a África, interromperam a fuga, com seus perseguidores permanecendo na Grécia. Isto dever ser entendido apenas em relação ao que tange a origem dos africanos brancos, ou seja, os que habitam a Berberia e a Numidia. No que se refere aos verdadeiros africanos da Terra dos Negros, todos são originais de Cus, filho de Cam, que é filho de Noé. Assim, qual seja a diferença entre os africanos brancos e os negros, todos procedem quase que da mesma origem. Com o qual, se vieram da Palestina, os palestinos provém igualmente da linhagem de Mesraim, filho de Cus; e se procederam dos sabeus, seriam também provenientes de Cus, por meio de seu filho Rhama. Existem muitas outras opiniões sobre isso, e por não me parecer necessárias, deixo-as de lado.

\section{Divisão dos africanos brancos em muitos povos.}

Os brancos da África estão divididos em cinco povos: Sanagia, Musmuda, Zeneta, Aoara e Gumera ${ }^{250}$. Os de Musmuda habitam o monte Atlas, na parte ocidental, começando de Ea até o Rio dos Escravos. Povoam também o lado do Atlas que está de frente ao meio-dia e a todas as planícies desse entorno. Possuem outras quatro províncias. As quais são: Ea, Sus, Guzzula, e a região do Marrocos. De modo similar, o povo Gumera ocupa os montes da Mauritania que estão na direção do Mar Mediterraneo, tomando toda a costa chamada Rif, a qual começa no Estreito das Colunas e segue para onde o Sol se levanta aos limites do reino de Telensin, chamado de Cesaria pelos latinos. Estes dois povos citados vivem separados dos demais, que normalmente estão mesclados e dispersos por toda a África; ainda que se conheçam entre si, de modo que sabem sobre a nação dos forasteiros, e sempre estão guerreando entre si em constante batalha, principalmente os habitantes da Numidia.

\footnotetext{
${ }^{249}$ Os povos da Itália, principalmente venezianos, chamavam de Morea, a região do Peloponeso, na Grécia. Ao se referir ao "Mar della Morea", Leão Africano está se referindo a um dos dois mares que atingem a costa dessa região: o Mar Adriático, ou o Mar Egeu. Não há aqui, indícios para definir qual dos mares está sendo mencionado por Leão Africano.

${ }^{250}$ Os cinco povos mencionados são de origem berbere.
} 
Dizem muitos autores que estes cinco povos costumam ter como casa a tenda própria dos nômades. Afirmam ainda que, livrando-se de uma longa guerra nos tempos antigos, perderam-na e se converteram em vassalos dos vencedores, e foram enviados para viver nas cidades, enquanto que os vencedores fizeram-se donos dos campos e os tomaram por moradas. Este raciocínio está quase provado, já que muitos dos que habitam no campo usam a mesma linguagem dos que vivem nas cidades, motivo pelo qual os Zenetes camponeses falam da mesma maneira que os Zenetes das cidades, e assim em muitas outras situações. Os três povos que mencionei vivem nos campos de Temesna: os Zeneta, Aoara, Sanagia. Às vezes conhecem a paz e outras vezes guerreiam, movidos, creio eu, por antigas parcialidades. Alguns desses povos tiveram reinos por toda a África, como os Zenetes, que expulsaram a casa de Idris, legítimo senhor de $\mathrm{Fez}^{251}$ e fundador desta cidade. A estirpe destes Zenetes é chamada Mecnasa. Mas veio depois outra família de Zenetes de Numidia, chamada Magraoa, a qual depôs aos Mecnasa do reino que eles haviam tomado dos legítimos senhores. E, pouco tempo depois, os novos Zenetes também foram expulsos por alguns procedentes do deserto da Numidia. Estes eram de uma prole dos "Zanigi” chamada Luntuna. Arruinaram toda a região de Temesna, e destruíram a todos os povos que ali moravam, exceto aqueles de sua mesma origem, e os puseram a viver em Duccala. Esta tal família edificou a cidade de Marrocos e então aconteceram mutações da fortuna que fizeram com que um grande homem nas coisas de sua fé e predicador muito apreciado, chamado de "Elmadi ${ }^{252 ", ~ s e ~}$ rebelasse e firmando um acordo com os "Argia", que eram da estirpe de Musmoda, derrubou a família de Luntuna e fez-se senhor. Depois da sua morte foi eleito como sucessor um de seus discípulos, Abdul Mumen da Banigueriaghel ${ }^{253}$, da linhagem dos Sanagia, e o reinado dessa família durou cerca de cento e vinte anos, senhoreando quase toda a África. Os de Sanagia foram logo privados de seu reino pelos Banimarini ${ }^{254}$, da família dos Zeneti, que duraram no poder cerca de cento e sessenta anos. Seu domínio

\footnotetext{
${ }^{251}$ Nesse trecho há duas questões a serem justificadas. Em primeiro lugar, Leão Africano utiliza a nomenclatura "casa de Idris" para fazer menção à dinastia árabe xiita Idríssida que reinou no Marrocos entre 789 e 985 d. C.

${ }^{252}$ Em árabe, "al-mahdi" (الدهـى): "o bem guiado", que virá restabelecer a religião verdadeira, liderando a comunidade de fiéis de maneira justa parao Juizo final. O "mahdi" é uma figura "messiânica" presente na escatologia sunita e xiita. Muitos líderes políticos da história islâmica se designaram como "mahdis", aproveitando os benefícios simbólicos de ser visto como uma figura salvadora. Luz Gómez García afirma que: "la figura del mahdi, en la cual el pueblo llano ha cifrado sus esperanzas en tiempos difíciles, ha tenido gran arraigo en el islam africano, quizá por sus conexiones con figuras ancestrales, como los hechiceros o los jefes tribales". Luz Gómez García. Diccionario de islam e islamismo. Madrid: Espasa, 2009. p. 197.

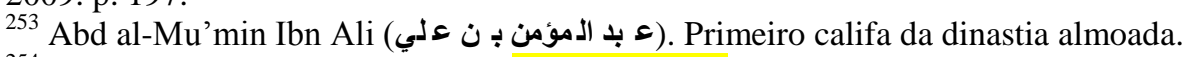

${ }^{254}$ Dinastia dos Marínidas (مرينيون). Ver Capítulo 1.
} 
teve fim por obra de Baniguatazi ${ }^{255}$, da estirpe de Luntuna. Estes Banimarini guerrearam contra os Banizeijan ${ }^{256}$, reis de Telensin, que são de origem Zanagi e da estirpe dos Magraoa. Guerrearam também com os Afaza ${ }^{257}$, reis de Tunis, descendentes dos Antata, da estirpe de Musmoda. Vê-se, pois, como cada dos cinco povos tem estado envoltos em vicissitudes e tarefas por aquelas regiões. A verdade é que, o povo de Gumera e de Aoara nunca teve títulos de domínio, embora estes houvessem também senhoreado em alguns lugares, como se lê nas crônicas dos africanos, e o tempo de seus senhorios foi justo o fez essa gente entrar na seita de Maomé, já que no passado, cada povo teve separadamente acolhida no campo, e cada um favorecia a sua parte. E compartilhando os trabalhos necessários ao viver humano. Os donos do campo se dão ao governo e reprodução dos animais, enquanto os habitantes da cidade servem às artes manuais e a trabalhar terrenos. E todos estes cinco povos estão comumente divididos em seiscentas estirpes, conforme consta na árvore da ascendência dos africanos. Um escritor de sua história, certo Ibnu Racu ${ }^{258}$, o qual eu pude ler fartamente e tem por certo muitos outros autores, afirma que o atual rei de Tombutto, e aquele que foi de Melli, o de Agudez, são de origem Zanaga, ou seja, que também é habitante do deserto.

\section{Diversidade e conformação da língua africana.}

Todos os cinco povos, divididos aqui em centenas de nações e em milhares de milhares de habitantes, se entendem em uma língua, a qual comumente chamada por eles de Aquel Amarig ${ }^{259}$, que quer dizer língua nobre. Os árabes da África chamam-na de língua berbere, que é a língua africana nativa. Esta língua é diversa e diferente de todas as outras, ainda que se encontre nela algumas palavras da língua árabe, que alguns consideram e usam como testemunho de que os africanos descendem da linhagem dos sabeus, povo da Arábia Feliz; segundo já deixamos dito. Mas os de opinião contrária afirmam que tais vozes árabes, que se encontram na dita língua, foram fornecidas com posterioridade quando os árabes entraram na África e se apoderaram dela, mas esses

\footnotetext{
255 Dinastia Wattásida (وطا سد يون)

${ }^{256}$ Dinastia dos Zaiânidas (زيانيون).

257 Dinastia dos Hafsidas (الحفصيون)

${ }^{258}$ Provavelmente, Ibn Rashiq.

${ }^{259}$ Em berbere: amazigh (homem livre). É o nome utilizado pelos berberes para se referir ao seu próprio povo. As línguas berberes são chamadas de Tamazigh (†॰Г。Ж乏५†). Leão Africano pode estar se referindo ao Awjila, nome de um Oasis cujos habitantes falam uma língua berbere com o mesmo nome. Localiza-se na atual Cirenaica líbia.
} 
povos eram broncos de entendimento e ignorantes, tanto que nenhum livro deixaram para que pudesse aduzir em favor de uma opinião ou de outra. Mantém, entretanto, algumas diferenças lingüísticas entre eles e não somente na pronúncia senão também no significado de muitos e muitos vocábulos, e os que são mais próximos e possuem mais familiaridade com os árabes, mais palavras deles têm em sua língua. Quase todo o povo de Gumera usa a fala árabe, mas corrompida; e muitos da estirpe e gente de Aoara falam árabe, também alterado; o que ocorre por haver mantido conversação com os árabes durante muito tempo. Na Terra dos Negros falam-se diversas línguas, uma das quais é chamada por eles de sungai ${ }^{260}$, e a falam em numerosas regiões, como Gualata, Tombutto, Ghinea, Melli e em Gago. A outra língua, chamam-na guber, e é usada em Guber, Cano, Chesena, Perzegreg e Guangra. Uma terceira é mantida no reino de Borno, e é semelhante a que se fala em Gaoga. Ainda se conserva outra língua no reino da Nubia e esta é influenciada pelo árabe, pelo caldeu, e pela fala dos egípcios; ainda que em todas as cidades da África, (abarcando as marítimas sobre o Mar Mediterrâneo até o monte Atlas) todos os que ali habitam falam geralmente uma língua arábica corrompida; exceto em toda a extensão do reino do Marrocos, e no próprio Marrocos, onde se fala a língua berbere, assim como nos territórios da Numidia, tanto entre os númidas da Mauritânia e vizinhos de Cesaria, como entre os mais próximos dos reinos de Tunis e Trípoli todos universalmente uma língua arábica corrompida.

\section{Árabes habitantes das cidades da África.}

No exército enviado por Otmen ${ }^{261}$, o terceiro califa, no ano 400 da Hégira ${ }^{262}$, chegou à África um grandíssimo número de árabes, que entre nobres e gente simples somou-se cerca de oitenta mil pessoas; conquistaram muitas regiões e depois, todos os principais e nobres voltaram para a Arábia. Permaneceram, entre outros, o capitão geral do exército, cuji nome era Ucba Jebnu Nafic ${ }^{263}$, o qual já havia construído e fortificado a cidade de Cairaoan, e que estava constantemente temeroso de ser traído pelas gentes

\footnotetext{
${ }^{260}$ As línguas de songhai são um conjunto de idiomas nativos diretamente relacionados aos povos que habitavam a extensão do rio Níger, nos atuais Mali e Níger. No período de Leão Africano, a região foi submetida a um dos maiores impérios da África, o Songhai. Foi destruído pelo reino do Marrocos em 1591.

261 Uthman ibn Affan (ع ثمان بـ ن فـان), terceiro califa islâmico do período dos rashidun, os "perfeitamente guiados" (الدرا شدئة). Governou o Império islâmico entre 644 e 656 d.C.

${ }^{262}$ Sobre a questão da confusão de calendários utilizados por Leão Africano, VER CAPÍTULO II.

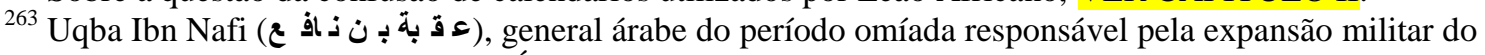
Império árabe-islâmico no Norte da África. Fundou a cidade de Kairouan, na atual Tunísia.
} 
das costas de Tunis e de que, se forças sicilianas não chegassem em seu socorro, seria combatido, então, com a grande quantidade de tesouro que conquistou, retirou-se para o deserto adentro e longe de Cartago, a umas cento e vinte milhas, fundou a cidade de Cairaoan e ordenou aos seus chefes e ministros que se estabelecessem em lugares fortificados, os mais seguros e adequados para a sua defesa, e onde não houvesse fortalezas, que as construísse. Isto foi feito, e os árabes, já em segurança, converteramse em cidadãos daquele país e se mesclaram com os africanos e, na medida em que estes foram senhoreados pelos italianos durante muito tempo, conservavam a língua italiana e com ela os árabes foram corrompendo a sua própria língua, a qual também se mesclou a todas as falas africanas. Isso fez com que dois povos diversos passassem a formar um único povo. A verdade é que os árabes sempre tiveram o costume, e seguem tendo, de marcar sua origem pela via paterna, como se usa entre nós, e os berberes também o fazem, de modo que não haja homem por mais importante que seja, que não adiciona a seu nome o sobrenome de sua origem, árabe ou berbere.

\section{Árabes que, na África, ao invés de casa, vivem em tendas.}

Os pontífices maometanos sempre proibiram os árabes de atravessar o Nilo com suas famílias e suas tendas, até que por volta do ano 400 da Hégira, um califa cismático lhes concedeu licença para fazê-lo. Isso porque um amigo e vassalo desse califa, rebelou-se; amigo esse que passou a reinar na cidade de Cairaoan e em quase toda a Berberia; depois da morte desse amigo o reino permaneceu na mão de sua família por um tempo.

Segundo li nas histórias africanas, no tempo de Elcain $^{264}$, califa e pontífice dessa dinastia herética, o poder desse soberano se estendeu tanto que o califa mandou um de seus servos e conselheiros, chamado Geoar, ao Ocidente com um grandíssimo exército que conquistou toda a Berberia, a Numidia e avançou até a província de Sus, recolhendo os tributos e utilidades dos reinos da citada província. Ao final da campanha e retornando ao seu senhor, pôs nas mãos do mesmo ouro e tudo o que trouxe de suas conquistas. Vendo o valor e o feliz resultado de seu empreendimento, o califa pensou em colocá-lo em uma empresa maior. Este lhe respondeu:

\footnotetext{
${ }^{264}$ Trata-se do califa Muhammad al-Qaim Bi-Amrillah: segundo califa da dinastia fatímida e importante imã do Ismailismo professado pela citada dinastia.
} 
_ Meu Senhor, eu te prometo que, assim como ganhei para ti essas regiões do poente, eu serei o responsável pelo seu domínio em todos os reinos do levante: do Egito, da Síria, e de toda a Arábia, vingando as ofensas e ultrajes que foram feitos aos teus antecessores pela dinastia de Labús ${ }^{265}$, não deixarei de colocar-me em quantas dificuldades e perigos forem necessários, até ver-te novamente no antigo trono de teus nobres e generosos antepassados, os ilustres progenitores do teu sangue.

Convencido o califa dos ânimos e promessas de seu vassalo, preparou um exército de oitenta mil combatentes, com muito ouro e mantimentos, e ao seu fiel e valoroso servo enviou o exército pelo deserto localizado entre a Berberia e o Egito. Quando chegou inicialmente à Alexandria, o governador do Egito retirou-se em direção a Bagdá para reunir-se com o califa Elvir ${ }^{266}$ e, em poucos dias, Geoar apoderou-se de todas as regiões do Egito e da Síria com pouca resistência. Mesmo assim, não deixou de temer que o califa de Bagdá o surpreendesse e encurralasse com tropas da Ásia, vencendo suas defesas e exércitos da Berberia. Pensou então, que era necessário fazer uma fortaleza para poder amparar sua gente e conter o ímpeto dos inimigos. Ele, assim, edificou uma cidade circundada de muros, em que deveria continuamente ter um de seus homens de confiança em guarda com uma parte de seu exército. A essa cidade pôs o nome de Elcaira, a qual seria chamada na Europa de Cairo, e que, dia após dia, acolhendo em suas fronteiras aldeias, povoados internos e do entorno, foi aumentando até o ponto de que em toda parte do mundo, outra similar não se encontrava. Vendo Geoar que o califa de Bagdá não movimentava nenhum aparelho de batalha contra ele, avisou seu senhor que as regiões conquistadas prestavam-lhe obediência e que tudo havia acabado; estava em paz, bem defendido e protegido; portanto, quando parecesse conveniente a sua Felicidade ${ }^{267}$ vir pessoalmente ao Egito, mais valeria a sua presença para o que faltava por fazer; do que centenas de milhares de soldados, e seria de se esperar também que o califa de Bagdá, abandonando seu pontificado e seu reino, fugisse. Com esta bela e magnânima exortação chegada aos ouvidos do senhor, este, sem pensar muito e considerar o que podia contrariamente acontecer, senão envaidecido pela adulação da favorável fortuna ${ }^{268}$, preparou um grande exército e partiu, deixando

\footnotetext{
${ }^{265}$ Referência à dinastia abássida; que governou o califado árabe-islâmico entre 750 e 1299 d. C. $266 * * *$ Personagem histórico ainda não identificado.

${ }^{267}$ Pronome de tratamento honorífico.

${ }^{268}$ De acordo com a versão original, o substantivo "fortuna" é precedido da palavra "seconda", o que, se traduzido literalmente, não confere sentido à frase. Dessa forma, pode tratar-se de um engano paleográfico de leitura da escrita original, já que em cotejo com outras traduções feitas em espanhol
} 
como governador e general capitão de toda a Berberia, um príncipe do povo de Zanagia, o qual não era somente amigo, mas também servidor de sua casa. Chegado o califa ao Cairo e recebido reverentemente por seu escravo, sentiu-se animado a maiores empresas ainda e enviou um grande exército contra o califa de Bagdá. Enquanto isso, o governador que ficou com o comando da Berberia se rebelou e se ofereceu em obediência ao califa de Bagdá, o qual se alegrou e dispensou-lhe grandes privilégios, fazendo-lhe rei de toda a África. Conhecida a notícia pelo califa Elcain no Cairo, foi tomada de maneira amarguíssima, parte por encontrar-se fora do seu reino, e parte por ter gasto todo seu ouro e as coisas oportunas que tinha trazido consigo: não sabendo o que fazer, maldizia muitas vezes o conselho de seu vassalo. Um secretário próximo a ele, homem douto e de bela e pronta inteligência, ouvindo o lamentar do senhor e prevendo a súbita ruína que pairava sobre sua cabeça caso não fosse remediada a situação o quanto antes, começou a confortá-lo e a aconselhá-lo com estas palavras:

_ "Senhor, a fortuna é extremamente mutável; não tens que duvidar de vossa virtude pelo incidente ocorrido. Se dás importância ao que este fidelíssimo servo quer infundirte bem e lealmente, não duvido de que recuperarás brevemente tudo o que por rebeldia foi-te alienado e obterás tão logo desejes. Não deves contratar soldado algum: mas, o exército que colocarei em suas mãos é o que deverás recompensar, pelas razões que direi."

O senhor ouviu as palavras e alegrou-se; demandando ao secretário como deveria agir. Em seguida, o secretário respondeu:

_"Meu Senhor, vós sabeis que os árabes se multiplicaram em tal número, que agora a Arábia não pode mais abarcá-los; seus rendimentos não são suficientes para manter seus animais, e tem sido difícil para eles encontrar lugar para viver, de modo que muitos passariam para a África se meu senhor o conceder. Dê permissão para que eles possam fazer essa passagem e eu colocarei nas mãos dos mesmos uma grande quantidade de ouro."

(Fanjul) e em francês (Biblioteca Nacional Francesa), opta-se por termos como "fecunda" e "par le beau semblant que fortune luy faisoit". Uma saída possível para esse problema é considerar "seconda" como particípio do verbo "secundar", no sentido de "criar condições para (surgimento ou ocorrência de algo); propiciar, favorecer." Essa acepção do termo "secundar" foi extraída do Dicionário Eletrônico Houaiss da Língua Portuguesa. 
O fim proposto pelo secretário não foi acatado pelo senhor, pois se considerou que os árabes arruinariam a África de tal maneira que nem os rebeldes, nem o próprio senhor gozariam dessas terras. Mas, de outra parte, sabendo que aquele reino estaria perdido, o senhor pensou em, ao menos, conquistar uma boa quantidade de dinheiro que a ele ofereciam e vingar-se também de seu inimigo, ao invés de perder tudo. Disse, pois, a seu conselheiro, que ele anunciasse a formação de um bando, autorizando a qualquer árabe que pagasse um dinar por cabeça, passar pela África com grande alvedrio e licença, mas com a obrigação de ser inimigo do novo líder rebelde. Com isso, cerca de dez linhagens distintas integraram o bando, metade da Arábia Deserta alguma estirpe da Arabia Feliz. O numero de aptos ao combate aproximou-se de cinquenta mil: mulheres, crianças e animais eram quase infinitos. Sobre tudo isso, contou de forma diligente Ibn Rashiq, historiador africano anteriormente referido. Ora, passados poucos dias e havendo ultrapassado o já mencionado deserto entre Egito e a Berberia, assediaram primeiramente Trípoli da Berberia; entraram na cidade pela força, saquearam-na, e mataram a todos que puderam. Dali foram para Cabis ${ }^{269}$ e a destruíram. Finalmente, assediaram a Cairuan, cidade em que o líder rebelde, provido de disposições e equipamentos, resistiu muito bem ao assedio durante oito meses, e depois perecendo pela força, sendo saqueada e levando o líder rebelde ao assassínio.

Os árabes dividiram os campos entre si e neles viveram, impondo a cada cidade pesadíssimos encargos. Por isso foram se transformando em senhores de toda a África até a ascensão no reino do Marrocos de Youssef, filho de Tasufin ${ }^{270}$, que foi o primeiro rei marroquino. Com todo o seu poder, esse novo rei resolveu ajudar os que fossem parentes ou amigos do rebelde morto, e não cessou até libertar as cidades do domínio dos árabes. Esses árabes ainda seguiam morando no campo, assassinando e roubando o quanto podiam: enquanto os parentes do líder rebelde reinavam em diversos lugares. Mas, ascendendo ao reino do Marrocos, Mansour, o quarto rei e pontífice da seita Almoada, resolveu afastar-se do exemplo de seus antecessores que estiveram a favor dos parentes do líder rebelde; então ele começou a fazer o contrário, retirando o poder desses parentes. Astutamente, acertada a paz com o grupo próximo ao líder rebelde, induziu os árabes a fazerem a guerra em seu lugar, da qual não tiveram dificuldade em vencer. Mansour levou consigo todos os notáveis e principais árabes aos reinos do

\footnotetext{
${ }^{269}$ Gabès: cidade ao sul da atual Tunísia.

${ }^{270}$ Youssef Bin Tasufin: inaugurador da dinastia almorávida.
} 
poente, dando como morada aos mais nobres Duccala y Azgar: àqueles de menor condição concedeu morada na Numidia. Porém, com o tempo, os que eram escravos dos númidas recobraram sua liberdade; e apesar destes últimos, dominaram as terras que Mansour os entregou, alargando diariamente seus confins.

Aqueles que ocuparam Azgar e algum outro lugar da Mauritânia ${ }^{271}$ foram reduzidos a servidão; já que os árabes são, fora do deserto, como um peixe fora d'água ${ }^{272}$. Teriam voluntariamente fugido em direção ao deserto, se os possuidores da Berberia não impedissem a passagem pelas montanhas do Atlas, e também não podiam andar pelos campos dominados por outros árabes, assim, deixando de lado sua soberba, deram-se ao pastoreio y a agricultura, habitando também em tendas, em vez de fazê-lo em cabanas ou casas rústicas. Veio juntar-se a tal miséria a obrigação de pagar tributos a cada ano aos reis da Mauritânia. Aqueles de Duccata, protegidos pelo seu grande número, livraram-se de todos os encargos. E os árabes que permaneceram em Tunes já que Mansour havia se recusado a levá-los consigo, com sua morte, apoderaram-se de Tunes e de suas proximidades. Seu domínio perdurou até a sublevação da família de Abu Hafs, com a qual os árabes prometeram respeitar seu domínio em troca da metade dos tributos e dos frutos produzidos pelo reino. Este pacto e acordo duram até nossos dias, mesmo que os reis tunisinos não possam contentar a todos: a multidão de árabes supera os ganhos e utilidades do reino inteiro; as pessoas favorecidas estão obrigadas a manter os campos em paz, o que fazem sem danos a nada nem a ninguém; mas as pessoas privadas de provisões entregam-se a rapinagem, a matança e a perpetrar todo o mal que pode. Estão habituadas a emboscar-se e, quando passa algum viajante, encarceram, roubam e matam, de modo que não existe ali um caminho seguro e os mercadores que querem ir a algum lugar de Tunes, levam consigo, por questões de segurança, uma companhia de arcabuzeiros, e, ainda assim, passam por duas dificuldades nada pequenas: uma a de pagar aos árabes autorizados pelo rei uma grandíssima taxa; e a outra, bem pior, é que na maioria das vezes são assaltados pelos próprios beduínos e, não sendo suficiente a defesa, ficam privados de seus bens, equipamentos e de suas vidas.

\footnotetext{
${ }^{271}$ Não confundir com o atual território da República Islâmica da Mauritânia. Aqui, Leão Africano referese ao território marroquino.

${ }^{272}$ Possivelmente, João Leão Africano refere-se aqui aos berberes, e não aos árabes. Não se pode afirmar que foi um simples engano, ou se o viajante deduziu que os europeus conheciam os berberes como "árabes do deserto".
} 


\section{Divisão dos Árabes vindos a morar na África, os quais são chamados de Árabes berberes.}

Os árabes que entraram na África pertencem a três povos distintos: o primeiro se chama Cachin; o segundo é chamado Ilel; e o terceiro Machil. Cachin divide-se em três linhagens: Etegi, Sumait e Sahid. Etegi se divide também em três partes: Dellegi, Elmuntefig e Sobair, divididos em infinitas gerações. Ilel ainda se divide em quatro: Beniemir, Rie, Sufiene Cusain. Benemir parte-se em Uroa, Ucba, Abru, Muslim. Rie se divide em Deuvad, Suaism Asgre, Elcherit, Enedir e Garfa, cujas seis partes também se dividem em infinitas gerações. Machil se divide em três: Mastar, Utmen e Assan. Mastar se divide in Ruche e Selim. Utmen se divide em outras: Elasin e Chinana. Assan se divide em Deviessen, Devimansor, Deviubeidulla: Deviessen, em Dulein, Vodei, Berbus, Racmen e Amr; Devimanor, em Emrun, Menebbe, Usein e Abulusein; Deviubeidulla em Garagi, Edegi, Teleb e Geoan. E todos estes dividem-se infinitamente, dos quais não são apenas difíceis, mas impossíveis de se recordar.

\section{Divisão das moradias dos Árabes, e o número deles.}

Os Etegi foram os mais nobres e os principais dentre os árabes, e foram conduzidos por Mansour a morar em Duccala, e também nas planícies de Tedle. Em nossos dias, eles têm sido muito molestados, ora pelo rei de Portugal, ora pelo rei de Fez; e contam com quase cem mil guerreiros, metade a cavalo.

Os Sumait foram para o deserto da Líbia, que seguem aos de Trípoli: raramente vão pela Berberia, onde não possuem domínio nem espaço algum. Senhoreiam, em contrapartida, o deserto com seus camelos, e há entre eles cerca de oitenta mil homens preparados para a vida militar, a maior parte a pé.

Os Sahid habitam também o deserto da Líbia, e se desenvolvem com familiaridade no reino de Guargala. Possuem infinitos rebanhos e fornecem carne a todas as cidades e lugares próximos a seus desertos, mas isso ocorre, sobretudo, no verão. Durante o inverno, não saem de seus desertos. São aproximadamente cento e cinquenta mil, mas possuem poucos cavalos. 
Os Dellegi vivem em diversas regiões; a maior parte nos confins de Cesaria e nas regiões do reino de Buggia, e devem pagar tributos aos seus senhores vizinhos. A parte menor ocupa as planícies de Acdesen, os confins da Mauritânia e o monte Atlas, dando tributos ao rei de Fez.

Os Elmuntefig habitam as planícies de Azgar; e são chamados atualmente Elcalut ${ }^{273}$, pagam também tributos ao rei de Fez e podem dispor de cerca de oito mil cavalos bem treinados. Os Sobaich, (a maioria e os melhores) vivem nos confins do reino de Gezeir e recebem provisões do rei de Telensinm e dominam muitas terras na Numidia; contam com pouco menos de três mil cavalos e são muito dispostos ao confronto. Também estes são donos de muitos camelos, e refugiam-se no deserto durante o inverno, enquanto outros habitam as planícies que ficam entre Sala e Mecnesa. Possuem ovelhas e bois, trabalham a terra e também pagam tributos ao rei de Fez. Possuem em torno de quatro mil cavalos otimamente treinados.

\section{O povo de Ilel e suas moradas.}

Entre os Ilel, a maior estirpe pertence a o ramo de Beniamir, habitantes dos confins dos reinos de Telemsin e de Oran, estendendo-se pelo deserto de Tegorarin. Estes são tributários do rei de Telemsin, e são homens de muita façanha e muito ricos, tendo cerca de seis mil cavalos belos e bem treinados. Os Urua dominam os confins de Mustuganim, são homens selvagens e ladrões, estão mal equipados e não se desvencilham do deserto por falta de dinheiro e domínios na Berberia. Possuem cerca de dois mil cavalos.

Os Ucba habitam os confins de Meliana, e são pouco provisionados pelo rei de Tenes. É também gente assassina e distante de sentimentos de humanidade. Possuem cerca de mil e quinhentos cavalos.

Os Abru habitam as planícies entre Oran y Mustuganim. São trabalhadores do campo e pagam tributos ao rei de Telensim; possuem apenas algumas centenas de cavalos.

\footnotetext{
273 No original: “... e sono da' moderni chiamati Elcalut..." Preferi traduzir o vocábulo "moderni” pelo sentido conjuntural da frase, não ressaltando o sentido que o citado vocábulo pode adquirir na linguagem cultural do século XVI.
} 
Os Muslim habitam o deserto de Masila, o qual se estende em direção ao reino de Buggia. Também são ladrões e assassinos. Recebem Benefícios de Masila y algumas outras terras.

Os Riec habitam o deserto da Líbia na direção de Constantina e possuem grande domínio sobre uma parte da Numídia. Estão divididos em seis partes, todos são prodigiosos nas armas e nobres. Recebem auxílios do rei de Tunes e acumulam cerca de cinco mil cavalos.

Os Suaid habitam o deserto que se dilatam em direção ao reino de Tenes, e gozam de grande reputação e domínio. O rei de Telemsin os guarnece: são nobres, competentes e concordam com tudo.

Os Asge vivem submetidos a diversas tribos árabes e hpa uma grande quantidade deles que vive em Gurit junto ao povo de Emram, enquanto que outra parte deles convive com os árabes de Duccala em um local vizinho a Azefi.

Os Elcherit habitam as planícies de Elin em companhia dos Saidima. Recebem tributos do povo de Ea e são vis e pobres. Os Enedr também vivem nessas planícies de Ea, e todos os árabes de Ea possuem cerca de quatro mil cavalos, ainda que estejam mal providos de arreios e equipamentos.

Os Garfa habitam em diversos lugares; carecem de chefes e são mesclados com outros povos, sobretudo, com o povo de Manebba e de Emram. Eles transportam dátiles ${ }^{274}$ de Segelmessa para o reino de Fez, de onde trazem os mantimentos que necessitam.

\section{O povo Machil, suas moradas e seu número.}

Os Ruche, descendentes de Mastar, habitam os confins dos desertos próximos a Dedes e Farcala. São pobres e por isso possuem poucos domínios. São, porém, homens talentosos a pé ${ }^{275}$, tanto que muitos se envergonham de que um homem a pé seja vencido por dois a cavalo. São tão rápidos em sua caminhada que ninguém os pode

\footnotetext{
274 Possivelmente tâmaras; fruto da palmeira Phoenix dactylifera, alimento muito difundido e característico do Norte da África. Para não cometer nenhum equívoco, optarei por manter na tradução o termo "dátil", ou "dátiles".

${ }^{275}$ Talvez João Leão Africano esteja se referindo ao fato de que o citado povo seja melhor no enfrentamento militar de infantaria do que à cavalo.
} 
seguir a cavalo, mesmo no decorrer de um longo caminho. Possuem cerca de quinhentos cavalos e oito mil combatentes a pé.

Os Selim habitam as proximidades do rio Dara e viajam pelo deserto. São ricos e uma vez ao ano levam suas mercadorias a Tombutto, cujos reis os têm como favoritos; e em Dara $^{276}$ possuem muitas propriedades, terras de cultivo e um grande número de camelos, bem como cerca de três mil cavalos.

Os Elhasim habitam as proximidades do mar Oceano, nos confins de Messe, reunindo cerca de quinhentos cavalos pessimamente adestrados. Uma parte deles habita em Asgar e são súditos do rei de Fez, enquanto que os de Messe são livres.

Os Chinana convivem com os Elcalut e também estão submetidos ao mesmo rei de Fez; são homens fortes e bem fornidos, com aproximadamente dois mil cavalos.

Os Deviessem dividem-se em Duleim, Burbus, Vodei, Racmen e Arar. Os Duleim habitam o deserto da Líbia junto ao povo africano Zanaga, e não possuem domínio nem recurso algum, por isso são pobres e grandes ladrões. Viajam eventualmente à província de Dara para fazer escambo de víveres por dátiles. Vivem de maneira desordenada e são cerca de dez mil pessoas, com quatrocentos a cavalo e o resto a pé. Os Burbus habitam bem no deserto da Líbia próximo à província de Sus; são muitos e pobres, apesar de possuírem muitos camelos e senhorearem Tesset ${ }^{277}$, mas eles não tem condições sequer de ferrar os poucos cavalos que possuem. Os Vodei habitam no deserto entre Guaden e Gualata. Dominam Guaden e recebem alem disso algum tributo do rei de Gualata, na Terra dos Negros. Seu número é quase infinito, podendo ser estimados em quase sessenta mil bons guerreiros, mas com poucos cavalos. Os Racmen controlam o deserto vizinho de Acca, dispõem de domínios e tem por hábito ir durante o inverno a Tesset para abastecer-se. São cerca de doze mil combatentes e também contam com poucos cavalos. Os Amr habitam o deserto de Taganot, recebem algumas poucas provisões das

\footnotetext{
${ }^{276}$ Possivelmente, um erro toponímico de João Leão Africano.

277 A concepção de pobreza aqui apresentada por João Leão Africano está adaptada a valores europeus. Para os padrões árabe-beduinos, a grande propriedade de camelos e o domínio sobre uma terra configura signo de riqueza. Fica claro que o sentido de pobreza aqui atribuído por João Leão Africano diz respeito às potencialidades comerciais do território e do povo local. Serafin Fanjul, em sua tradução desse texto, afirma que João Leão Africano erra ao considerar os Burbus como pobres, mas não deixa claro nenhuma hipótese sobre essa definição do autor. Por isso, reforço pela relevância do trânsito cultural promovido por João Leão Africano que, o conceito de pobreza aqui está mediado por valores que o viajante atribui aos seus potenciais leitores: os europeus cristãos do século XVI.
} 
comunidades de Tagavost e percorrem o deserto até Nun. São cerca de oito mil homens de guerra.

\section{Devimansor}

Os Deemrun, estirpe de Devimansor, habitam o deserto próixmo a Segelmesse e acampam pelo deserto da Líbia até Ighid, recebendo tributos dos povos de Segelmesse, Todga, Tebelbet e Dara. Possuem muitos campos de palmeiras, vivem como senhores e gozam de grande reputação. Contam com aproximadamente três mil cavaleiro; tendo entre eles muitos árabes, homens vis, mas dispõem de cavalos e de abundantes criações de víveres como os Garfa, e os Esge.

Outra parte do povo de Emrun tem domínio sobre algumas terras e casas da Numidia, até o deserto de Fighig, as quais proporcionam a eles muitos e consideráveis tributos. No verão, fixam-se na província de Garit, nos confins de Mauritânia, em sua parte oriental. Pessoas nobres e prodigiosas, os reis de Fez casam-se quase sempre com suas mulheres, de modo que tem amizade e parentesco com esses reis. Os Menebbe habitam também o mesmo deserto e dominam as províncias numidas de Matgara e de Reteb, São também homens talentosos, recebem alguma provisão do povo de Segelmesse e contam com cerca de dois mil cavalos. Os Usein são igualmente da linhagem dos Devimansor; habitam as proximidades dos montes Atlas e senhoreiam muitas montanhas povoadas, cidades e castelos que foram concedidos pelos Marínidas ${ }^{278}$,em troca de boa ajuda que deram no começo desse reinado. Seu domínio se estende entre os reinos de Fez e Segelmesse, sendo que seu chefe também senhoreia a cidade de Garseluin. Percorrem também o deserto de Eddara e são ricos e bravos homens, contando com cerca de seis mil cavalos. Em sua companhia vão por vezes outros árabes, mas sob a condição de vassalos.

Os Abuluseim habitam, uma parte, no deserto de Eddara, com pouco domínio sobre essas terras e sendo que a maior parte encontra-se em tamanha miséria que sequer conseguem manter suas tendas no deserto. É verdade que no deserto da Líbia ergueramse pequenas aldeias, mas também sob condições miseráveis, lutando contra a fome e pagando tributos aos seus parentes.

${ }^{278}$ Ver capítulo 1 dessa tese. 


\section{Deviubeidulla.}

Os Carragi são uma parte de Deviubeidulla, habitam o deserto de Benigomi e de Fighig. Possuem muitas terras na Numidia, e são provisionados pelo rei de Telensin, quem se esforça continuamente para restringi-los à vida pacífica e honesta, já que são ladrões e assassinam quantos podem. Possuem cerca de quatro mil cavalos e no verão costumam mudar-se para os confins de Telensin.

Os Edegi habitam um deserto vizinho a Telensin, chamado Angad. Não possuem domínios e provisões alguma, vivendo somente do assassinato e do roubo. Possuem cerca de quinhentos cavalos.

Os Teleb habitam uma planície de Elgezair $^{279}$ e percorrem o deserto até Tegdeat dominando as cidades de Argel e de Teddeles, mas em nossos dias, estas duas cidades conquistadas por Barba Ruiva ${ }^{280}$, que se fez rei. Agora, o povo de Teleb foi aniquilado; eram homens nobres, e muito valentes na milícia. Contavam com cerca de três mil cavalos.

Os Geoan vivem separadamente: uma parte com os Garagi, e outra com os Edegi, mas sempre como vassalos; o que suportam com boa paciência.

Agora, eu quero que saibas que os dois primeiros povos, Scachim e Ilel, são árabes da Arábia Deserta e descendem de Ismael, filho de Abraão; e que o terceiro povo, os Machil é da Arábia Feliz e são originários do reino de Sabá. Creem os maometanos que os descendentes de Ismael são mais nobres que os sabeus, razão pela qual eles tem guerreado longamente pela superioridade de nobreza, e compõem-se diálogos em versos, em ambos os lados em que cada um reafirma a virtude, o benefício e os bons costumes de sua gente. E é preciso saber também que os antigos árabes, anteriores aos ismaelitas $^{281}$ são denominados pelos historiadores africanos como Arabi aríba, ou seja,

\footnotetext{
${ }^{279}$ É provável que seja uma parte do atual território argelino, já que em árabe a Argélia é conhecida como al-Jazair (ال جز ائر

${ }^{280}$ Trata-se do capitão Khair ad-Din, de alcunha "Barba Ruiva". Um dos piratas mais lendários do mar Mediterrâneo que, por ser um constante incômodo aos navios do sultão otomano Selim I, foi reconhecido pelo sultão como soberano da cidade de Argel. Durante o governo de Solimão, o Magnífico, Barba Ruiva chegou a ser condecorado como capitão da Armada Otomana, transformando-se em um dos principais inimigos dos impérios cristãos no Mediterrâneo.

${ }^{281}$ João Leão Africano chama de "ismaelitas", os descendentes do personagem bíblico Ismael. Nenhuma relação com o grupo xiita dos Ismaelitas, ou septimâmicos, crentes na vinda de sete Imãs.
} 
“Árabes Arábicos”, enquanto que os ismaelitas são chamados de "Árabes Mustahraba”, "arabizados", ou "árabes acidentais", já que não nasceram árabes. Os árabes que passaram a viver posteriormente na África são conhecidos como "Árabes Mustehgeme", ou "berberizados", porque vivem em uma nação estrangeira ${ }^{282}$ e degeneradores da sua língua original mudaram seus costumes, e converteram-se em bárbaros.

Seria bom poder remontar à "memória da linhagem e da divisão dos africanos e árabes $^{283}$ ", já que há dez anos eu não leio nem vejo nenhum livro de história. Mas se alguém quiser saber mais profusamente, poderá ver na obra de Ibn Khaldun o que foi dito por mim acima.

\section{Costumes e modos de vida dos africanos que habitam o deserto da Líbia.}

Os cinco povos chamados Zenaga, Guenziga, Terga, Lemta, e Berdeva, são todos chamados pelos latinos de Númidas e vivem igualmente sem princípio ou razão alguma. Sua vestimenta é uma tira de pano estreito de lã grossa que cobre a mínima parte de sua pessoa, e alguns usam enrolado na cabeça um pedaço de tecido negro, quase como um turbante. Os mais notáveis e principais homens, para diferenciar-se dos demais, portam uma grande camisa de mangas largas, feita com tecido azul e de algodão ${ }^{284}$ trazido da Terra dos Negros por mercadores. Não cavalgam outro animal senão o camelo e sobre certa cela se coloca no espaço entre a corcunda e o pescoço dos camelos. É bonito vêlos cavalgar, principalmente quando metem uma perna sobre a outra e põem as duas no colo do camelo. Outras vezes assentam os pés ao montar em certos estribos sem apoio e, no lugar das esporas, usam um ferro preso a um pedaço de madeira da largura de um braço, não perfurando com tal ferro nada além das costelas do animal. Os camelos que servem para montaria tem frequentemente o focinho vazado como os búfalos que na Itália se encontra, e no orifício levam uma peça de couro com a qual se conduz e se segura o camelo, tal como se faz com a rédea nos cavalos. Para dormir utilizam várias

\footnotetext{
${ }^{282}$ No original, "istraniera nazione"

${ }^{283}$ João Leão Africano faz menção indireta à "História Universal" de Ibn Khaldun. Aqui, o autor admite a influência da ciência e da cultura islâmicas como um dos suportes de sua "tradução cultural" realizada na Descrizione Dell Affrica e delle cose notabili che quivi sono .

${ }^{284}$ No original, bambagio, e não "cotone". No cotejo com as versões em espanhol, do Prof. Serafin Fanjul, e na edição francesa de 1556, disponível à consulta na Biblioteca Nacional Francesa pelo sistema digital Gallica, confirma-se que a fibra em questão é o algodão pelo uso da palavra "algodón" na versão espanhola, e "cotton" na francesa. Para corroborar a escolha e por sugestão da Profa. Silvia Patuzzi confirmou-se a definição em consulta ao verbete "bambagia, e bambagio" do Vocabolario Degli Accademici Della Crusca: "Lanugine del frutto d' una pianta, simile a lana, bianchissima. Cotone."
} 
esteiras tecidas de juncos bem finos; e suas tendas são feitas de pelo de camelo e outras fibras rústicas que nascem entre os cachos dos dátiles. Com relação ao comer, ninguém que não os tenha visto poderia entender a paciência com que sofrem de fome. Sem o costume de comer pão, nem comida feita de nenhuma sorte, alimentam-se do leite de suas camelas, sendo costumeiro tomar pela manhã uma grande tigela, quente como quando sai da camela. À noite, comem uma carne seca fervida no leite e na manteiga, e que como é cozida, cada um pega a sua parte com a mão. Uma vez comida a carne, bebem o caldo que sobrou do cozimento, recorrendo às mãos ao invés de colheres. Depois bebem um copo de leite, e isso encerra o jantar. Enquanto dura o leite, eles não se preocupam com a água, principalmente na primavera. Ao longo desse período algumas pessoas não lavam as mãos e nem a cara, porque nessa estação do ano os Númidas não se deslocam para regiões em que haja água, contando com o leite e também pelo fato de que os camelos quando comem ervas, não precisam beber água. Por toda a vida até a morte, se entregam à caça ou ao roubo dos camelos de seus inimigos. Não param em lugar algum para comer em um prazo de três ou quatro dias, que é o quanto um camelo tarda para consumir a grama que comeu. Esta gente, que vive tão sem princípio e sem razão, tem em contrapartida, para cada um de seus povos um príncipe a maneira de um rei, ao qual rendem honras e muito obedecem. São ignorantes e sem conhecimentos, não de letras, mas de toda arte ou virtude, e é um povo em que há uma grande dificuldade de se deparar entre eles com um único juiz amparado pela razão, de modo que se alguém se encontra envolvido em litígio ou desagrado, para localizar a tenda de um juiz deve cavalgar cinco ou seis dias, pois entre eles não há quem estude, nem para aprender, se disponha a sair de seus desertos. Os juízes, entretanto, vêm e atendem com má vontade esta canalha por não poderem suportar seus costumes e modo de vida. Mas aqueles que o fazem são muito bem pagos, por que alguns deles chegam a receber até mil ducados ao ano, ou mais, ou menos, segundo o pobre critério de que seja suficiente para cada clientela. Os gentis homens dessa população portam na cabeça, como já disse, uma faixa negra, cobrindo a cara com uma parte desse tecido, escondendo-a salvo os olhos. Somente se descobrem quando comem pelo tempo que gastam para meter a comida na boca. Justificam esse costume argumentando que assim como é vergonhoso ao homem expelir o alimento, também é infame metê-lo para dentro. Suas mulheres são baixas e carnudas, mas não muito brancas, com traseiros volumosos e gordos, assim como os peitos, que usam bem apertados; mas de cintura fina. Tanto seu raciocínio quanto o toque de suas mãos são 
agradáveis, e as vezes usam de cortesia ao deixar que sejam beijadas, mas é perigoso ir além disso porque por tais causas matam-se uns aos outros sem perdão algum; e nesse contexto são mais sensatos do que muitos de nós ao resistir a portar cornos. Esses povos são ainda muito liberais, já que pela aridez de suas terras ninguém se aproxima de suas tendas, assim como eles tampouco se acercam dos principais caminhos. Mas as caravanas que passam pelo deserto devem pagar certos tributos aos príncipes, por cada cáfila $^{285}$ de camelo uma peça de tecido que pode valer um ducado. Eu passei acompanhado em caravana há alguns anos e, e como chegamos às planícies de Araoan, apresentou-se a nós o príncipe de Zanaga escoltado por quinhentos homens, montados em camelos e, após o pagamento, nos convidou a ir com ele até sua tenda para repousarmos por dois ou três dias. Porém, como sua tenda era aproximadamente oitenta milhas de distância de nosso caminho e nossos camelos estavam muito carregados, para não alongarmos a rota os mercadores não quiseram aceitar o convite. $\mathrm{O}$ príncipe então sugeriu que os condutores de camelos seguissem o caminho, e que os mercadores fossem ao seu alojamento, o que aceitamos. Quando chegamos, prontamente o bom homem mandou abater muitos camelos jovens, velhos, e mais outro tanto de castrados, além de alguns avestruzes que capturaram pela estrada. Mas os mercadores deram a entender que não se devem matar os camelos e, sobretudo, que não estão acostumados a comer carne de animais castrados, especialmente em público. O príncipe respondeu que entre seu povo, tinha-se por vergonhoso matar aos convidados somente animais pequenos, e principalmente a nós que éramos forasteiros, assim sendo, completamente alojados, comemos o quanto puseram na nossa frente. O banquete era composto de carnes assadas e cozidas, os avestruzes foram assados e levados à mesa em tabuleiros cheios de vegetais e boa quantidade de especiarias da Terra dos Negros. O pão era feito de miglio e panico $^{286}$, achatado e muito fino. No final foram servidos dátiles em abundância, grandes tigelas cheias de leite. Além de sua presença, O príncipe quis

\footnotetext{
${ }^{285}$ No original: "soma di cammello...".

${ }^{286}$ Nessa descrição do tipo de pão servido pelo príncipe de Zanaga, os grãos citados por João Leão Africano são pouco usuais no Brasil Por isso, a tradução do nome desses alimentos é imprecisa. O miglio seria a Panicum miliaceum, uma planta anual da família das gramíneas que precisa de pouca água para crescer. No Brasil, a Panicum miliaceum pode ser conhecida como "painço", "milho-miúdo" ou "milhete"; e é usada principalmente na alimentação de pássaros. Já a panico seria a Setaria iltalica, uma planta de talos estreitos que pode chegar a 20 centímetros de altura. João Leão Africano ressalta o uso dessas plantas na confecção do pão para reforçar a precariedade da oferta de alimentos nessa região, já que um alimento usual como o pão passa a ser feito de plantas adaptadas às condições adversas de clima e solo da região de Zanaga. O miglio se justificaria por crescer com pouca necessidade de água, e a panico por ter uma semeadura precoce, sendo de grande valia para a engorda de víveres, pois aos 50 dias de plantio, já pode ser consumida pelas criações. Apesar de difundidas na Europa, ambas os grãos citados são originários da Ásia.
} 
honrar o banquete com a participação de alguns de seus nobres e parentes, embora tenham comido à parte de nós. Fez virem também alguns religiosos e literatos, que foram sentar-se com ele. E enquanto durou o banquete, nenhum deles tocou no pão, mas apenas a carne e o leite. Percebendo o príncipe que aquilo nos assombrava e maravilhava, disse-nos com palavras agradáveis que nenhum deles era nascido naquele deserto que não gerava grãos, por isso se alimentavam dos produtos originários de sua terra natal e buscavam esses grãos todo ano para oferecer em honra aos forasteiros de passagem, ainda que fosse verdade que eles também comiam o pão em dias de festas solenes como a da Páscoa e do Sacrifício ${ }^{287}$. Fomos mantidos no alojamento por dois dias, sempre sendo cordial $^{288}$ conosco e nos honrando. No terceiro dia, o príncipe despediu-se de todos e quis nos acompanhar pessoalmente até que alcançássemos a caravana; e os digo em verdade que os animais que o senhor mandou matar para que comêssemos, valiam dez vezes mais que os tributos que lhe pagamos, e em sua fala e em tudo se podia saber que ele era nobre e cortês senhor, conquanto ele entendesse a nossa linguagem e nós a dele, e o que quer que fosse que nos dissesse e respondêssemos, era por meio de um intérprete. A vida e os costumes que acabas de conhecer desse povo, sao similares as dos outros quatro espalhados pelos desertos da Numidia.

\section{Do viver e dos hábitos dos árabes na África.}

Uma vez que os árabes são de diversos lugares, possuem diferentes modos e costumes de vida. Os que habitam entre a Numidia e a Líbia levam uma vida miserável, e cheia de muita pobreza, o que não os diferencia dos demais povos africanos habitantes da Líbia, ainda que sejam mais audazes que estes. Sabem comerciar com seus camelos na Terra

\footnotetext{
287 João Leão Africano estabelece uma aproximação explicativa entre a Páscoa cristã e o Id al-Adha islâmico (s يد الأ ضحى), a celebração que sucede a peregrinação religiosa à Meca. Trata-se de uma comemoração ao sacrifico de Abraão, que considera a possibilidade de imolar um de seus filhos como prova de seu pacto com Deus. O Antigo Testamento afirma que o filho em questão seria Isaque, enquanto que o Alcorão alega que o episódio envolveu Ismael, o primogênito de Abraão.

288 No original: "sempre facendoci carezze e onorandoci...". De acordo com o Vocabolario Degli Accademici Della Crusca, o termo carezza (de onde vem carezze), pode ser definido como "bondade amigável”. Da acepção mais contemporânea, pode-se admiti-la como "acariciar", "afagar”, aproximandose metaforicamente da ideia de acolhimento. Na tradução espanhola de Serafin Fanjul, optou-se pela forma "siempre agasajándonos y honrándonos...", o que reforça pela tradução, o sentido metafórico original. Já na tradução francesa do século XVI aqui utilizada e anteriormente referida, vê-se como "... jamais de nous entretenir humainement, et montrer grand signe d'amitié”. A opção pela tradução conjuntural fica evidente no caso francês.
} 
dos Negros e tendo cavalos em grande número: os que na Europa são chamados de cavalos berberes. De forma contínua se prestam à caça, desde a de cervos, asnos selvagens ${ }^{289}$, avestruzes, até a de outros animais. Não se pode silenciar que a maior parte dos árabes númidas é dada aos versos, e compõem longos cantos, descrevendo suas guerras, suas caçadas, assim como coisas de amor com grande elegância e doçura; trata-se de versos rimados, ao modo dos versos tradicionais da Itália ${ }^{290}$. São homens liberais, mas não possuem, no entanto, a faculdade para manter sua reputação, nem usar de cortesia; já que vivem, portanto, nesses desertos repletos de moléstias. Vestem-se ao modo dos númidas, salvo as mulheres, cujo vestuário apresenta algumas diferenças em relação ao das mulheres númidas. Os desertos onde habitam esses árabes estavam anteriormente nas mãos de povos africanos, os quais foram sendo expulsos pelos antepassados dos citados árabes por meio de guerras, desfazendo-se do domínio númida e permanecendo ali, em regiões desérticas vizinhas às terras dos dátiles, enquanto que os númidas desalojados passaram a habitar os desertos próximos a Terra dos Negros. Os árabes que habitam o interior da África entre o Monte Atlas e o mar Mediterrâneo, vivem melhor e são mais ricos que os outros, principalmente com relação as vestimentas, e acerca do abastecimento de cavalos, e a beleza e imponência de suas tendas. Mas, ainda que tenha muitos cavalos de grande beleza, esses não são velozes na corrida como os do deserto. Esses árabes trabalham suas terras e estocam grandíssima quantidade de grãos, possuem ovelhas e bois em um número quase infinito, e por essa razão não se põem a fixar-se em um único lugar, já que um terreno não basta para alimentar tantos animais. São por sua vez, mais bárbaros e naturalmente vis que a gente do deserto, mas são, não obstante, autônomos, ainda que uma parte deles, que vive no reino de Fez, está submetida ao pagamento de tributos a seu rei. Aqueles que habitam as cercanias do reino do Marrocos, e em Duccala, foram durante determinado tempo livres de tributos até que os portugueses dominassem Azafi e Azemor. Então, uma parte deles se rebelou e houve discórdias internas, fazendo com que o rei de Fez governasse em uma parte, e em outra o rei de Portugal. A carestia que se instalou nesse ano na África, os oprimiu de tal maneira que os miseráveis árabes da região voluntariamente foram para Portugal, oferecendo-se como escravos a qualquer que lhes desse comida. Nenhum deles permaneceu em Duccala. Em contrapartida, os árabes que habitavam o deserto

\footnotetext{
${ }^{289}$ No original: "d'asini selvatichi"

${ }^{290}$ Ao falar em Itália no século XVI, João Leão Africano refere-se à toda a Península Apenina, pois a unificação política e territorial da Itália contemporânea concretizou-se na segunda metade do século XIX sob o domínio monárquico da Casa de Savóia (1861-1946).
} 
vizinho ao reino de Telensin, e no deserto vizinho a Tunis, vivem do mesmo modo que seus senhores: cada um de seus príncipes recebe grandes provisões do rei, que os distribui e comparte com seu povo para impedir a discórdia e tê-los em paz e amigável união. Esses homens anseiam por andar em boa ordem, e terem os cavalos muito bem cuidados, e suas tendas são belas e grandes. São afeitos, no verão, a viagens até os confins de Tunis para se apoderarem de provisões, e em outubro se abastecem do que necessitam: do pão e de armas, e com isso retornam ao deserto, onde permanecesse por todo o inverno. Depois, na primavera, se divertem nas caças com cães e falcões, perseguindo toda a sorte de feras e de aves. Muitas vezes me alojei com eles, e me foi valioso por muitas coisas, e vi suas tendas mais providas de panos, de cobre, de ferro e de bronze, do que muitas das casas das cidades. Todavia, não é de se confiar nestes, porque roubam e assassinam gratuitamente; entretanto, são assaz corteses. Amam a poesia e costumam ditar versos elegantíssimos em sua língua comum, ainda que hoje sua linguagem esteja corrompida. Um poeta é pessoa cara aos senhores, que lhes conferem grandes recompensas, e não posso testemunhar aqui quanta pureza e graça residem em seus versos. As mulheres levam-se muito bem vestidas, com hábitos negros de largas mangas, sobre os quais portam um lenço da mesma cor, ou azul, envolvendose de maneira que suas extremidades passam sobre os ombros às costas, sustentados por botões de prata magistralmente trabalhados. De suas orelhas pendem muitas argolas também de prata, bem como luzem outros aros de suas mãos, pernas e tornozelos ${ }^{291}$, como é costume entre os africanos. Portam também estas mulheres um véu sobre a face, com aberturas na parte dos olhos, e logo que avistam um homem que não seja seu parente cobrem o rosto e guardam silêncio. Somente quando estão com seus maridos e familiares é que levantam o véu. Como os árabes tem o costume de se deslocarem de um lugar a outro, acomodam as mulheres sobre seus camelos em certas selas feitas como cestas, cobertas de belíssimos tapetes e tão pequenas que somente cabe uma única mulher. E no dia em que são escolhidos para combater, os homens levam também as mulheres para deixá-las confortáveis e menos afoitas. Essas mulheres estão acostumadas também a pintar a cara, o peito e os braços antes do casamento, praxe que

\footnotetext{
${ }^{291}$ No original: "calcagna". A tradução mais óbvia seria "calcanhar”, mas é claro que João Leão Africano está falando de tornozelos ("caviglia"). Como o toscano ou qualquer língua da Península Itálica do século XVI não eram línguas maternas para João Leão Africano; ou o autor cometeu um engano, ou preferiu reforçar que grandes argolas nessa parte do corpo podem tocar os calcanhares e portanto, podem ser vistas inclusive quando a mulher está de costas. O importante aqui, não é a precisão da palavra e do costume das africanas, mas o fato de que a abundância de um metal de grande valor comercial como a prata pode ser deduzida pelos costumes locais.
} 
se tem por muito gentil e que tomaram dos árabes africanos desde que vieram habitar entre eles, já que originalmente não se usava. Mas entre os cidadãos e nobres da Berberia não se costuma fazê-lo, suas mulheres se mantém com a mesma brancura com a qual nasceram. É certo que às vezes, e com uma tinta feita de fumaça de almíscar ${ }^{292}$ e açafrão, pintam na metade da bochecha algo como um escudo, um "quase triangulo" entre as sobrancelhas, algo como uma folha de oliveira no queixo, e algumas inclusive tingem todos os cílios. Esta forma é muito apreciada pelos poetas árabes e as pessoas nobres a consideram tão graciosa como gentil. Mas elas não portam esse embelezamento por mais de dois ou três dias, já que enquanto o levam, não podem aparecer diante de seus parentes, exceto ao marido e aos filhos, considerando-se que o fazem para incitar a luxúria e de que com esses adornos aumentam ferozmente sua beleza.

\section{Árabes que habitam o deserto entre a Berberia e o Egito.}

A vida destes é cheia de miséria, de modo que os lugares em que vivem são estéreis e brutos. Possuem ovelhas e camelos, mas em pequena quantidade dada a escassez de pasto. E por mais extensos que sejam os campos não há alguma em que se possa semear nenhuma sorte de grãos. Somente nas proximidades de uma quinta com pequenas hortas produtoras de dátiles, se planta algo de grão, tão pouco que não pode ser menos, já que os habitantes desse vilarejo sofrem continuamente entraves e provações dos que, mesmo lhes dando as vezes camelos e ovelhas em troca de dátiles e trigo ${ }^{293}$, no entanto, pela pouco quantidade, a tanta gente não basta. Por isso constantemente, muitos jovens árabes são entregues aos sicilianos ${ }^{294}$ como penhor ou fiança por grãos, e se dentro de um tempo acertado não se salda a dívida, ficam como escravos, devendo os pais entregar, para resgatá-lo, uma quantidade três veze maior da devida; de modo que muitas vezes são forçados a deixá-los nessa condição. Dessa maneira, procede que estes árabes são os piores e mais terríveis assassinos que existem no mundo e que quantos

\footnotetext{
${ }^{292}$ No original: "galla". Talvez em português: algália, certo perfume de almíscar e âmbar.

${ }^{293} \mathrm{Na}$ obra de Leão Africano, aparece a palavra "grano", cuja tradução direta seria "grão". Porém, de acordo com o Vocabolario degli Accademici Della Crusca, se aceita nos séculos XVI e XVII que "grano" seja sinônimo de "frumento"; o termo mais recorrente para "trigo". Desse modo, opto pelo uso contextual da palavra. Quando se refere ao produto específico, utilizo "trigo"; quando se refere ao produto generalizado, utilizo "grão".

${ }^{294}$ A referência dos sicilianos como vendedores de escravos mescla a informação sobre o tráfico de escravos à experiência pessoal de João Leão Africano, que em uma de suas viagens foi feito cativo e vendido como escravo por piratas sicilianos.
} 
forasteiros caiam em suas mãos, uma vez despojados do que têm, são vendidos aos sicilianos; tanto que há cem anos não passa caravana alguma pela costa do mar que contorna o deserto senhoreado pelos citados árabes. Mas se alguma caravana se arrisca, segue por terra adentro, a umas quinhentas milhas do mar. Eu, fugindo deles, percorri toda aquela costa em três barcos de mercadores. Como esses árabes nos viram, vieram correndo ao porto, demonstrando que queriam fazer comércio que nos seria proveitoso; mas não confiamos neles e ninguém quis baixar a terra firme enquanto não dispuseram como reféns nossos por segurança, alguns de seus filhos. Em seguida, compramos deles alguns animais castrados, manteiga e partimos subitamente, temendo sermos alcançados por corsários da Sicilia e de Rodes. Esses árabes são brutos, malvestidos, secos e macilentos por grande fome, como se a maldição de Deus tivesse caído desde sempre sobre esta danada e péssima geração sem nunca sair deles.

\section{Os Soava, criadores de ovelha, gente africana que segue o estilo dos árabes.}

São muitas as linhagens de africanos que se dedicam a criar ovelhas e bois, no que se esforçam todo o dia. A maior parte dessa gente habita o pé do monte Atlas, e também no próprio monte. Onde quer que estejam, são sempre tributários do rei, ou dos árabes, e deixo de lado os que habitam em Temesna, os quais são livres, possuem grande poder, falam a língua africana e alguns utilizam o árabe por causa da vizinhança e conversação que mantém continuamente com os árabes que habitam no campo de Urbe, nos confins de Tunis. Existe outro povo que vive nos limites de Tunis com os países dos dátiles, e é gente que muitas vezes teve coragem de fazer a guerra ao rei tunisiano, como ocorrido uns anos atrás, quando o filho do rei chegou de Constantina para cobrar-lhes os tributos e foi atacado pelo príncipe daquelas gentes que, entrando em guerra com dois mil cavalos, rompeu as defesas das forças do rei, matando-o e ficando com o que levava, sendo o ano de 915 da Hégira. Depois disso, o citado povo começou ter bom nome e muita estima. Muitos dos árabes que estavam a serviço do rei de Tunis fugiram dos lugares submetidos ao monarca e vieram a habitar com os vencedores, convertendo assim o líder desses vitoriosos em um dos maiores e mais famosos senhores que existe na África. 


\section{A fé dos antigos africanos.}

Os africanos dos tempos antigos eram quase idólatras, como são os persas, os quais adoraram o fogo, o Sol e ergueram belos e ornados templos em cuja honra ardia o fogo, dia e noite zelado sem ser extinto, à guisa dos romanos no templo da deusa Vesta, o qual as crônicas dos africanos e dos persas difusamente apresentam. É verdade que os africanos da Numidia e da Líbia adoravam os planetas oferecendo sacrifícios. Alguns dos negros africanos veneravam a Guighimo, que na língua deles significa "o senhor do céu". Chegaram a esse bom juízo sem serem informados nem por profeta, nem por douto algum. A partir de certo tempo foram introduzidos na lei judaica, que observaram durante longos anos, tanto que muitos reinos de negros fizeram-se cristãos e permaneceram nesta fé de Cristo até que se levantou certa seita de Maomé, no ano de 268 da Hégira. Foram então a pregar em suas terras, discípulos de Maomé e os converteram a essa fé, de modo que suas convicções tocaram as mentes dos africanos para aquela lei, já que todos os reinos dos negros que beiram a Líbia tornaram-se maometanos, ainda que hoje em dia, exista algum reino que permaneça cristão. Somente os que eram judeus foram totalmente destruídos pelos cristãos e africanos. Aqueles que vivem próximos ao mar Oceano, são todos gentis ${ }^{295}$ e adoradores de ídolos; como visto por muitos portugueses que ainda mantêm relações com estes. Os habitantes da Berberia também se mantiveram idólatras por muito tempo e fizeram-se cristãos somente duzentos e cinquenta anos antes do nascimento de Maomé, razão pela qual, aquela parte onde é Tunis e Trípoli foi dominada por senhores da Puglia ${ }^{296}$ e da Sicilia, da mesma forma que a costa da Cesarea e da Mauritânia foram senhoreadas pelos godos. Naqueles tempos, realmente, muitos senhores cristãos fugiram do furor destes godos, e deixando para trás seus nativos e doces distritos italianos, vieram a habitar as vizinhanças de Cartago, onde exerceram seu domínio. Mas, deve-se saber que estes cristãos da Berberia não mantiveram a observância e a ordem da Igreja romana, aderindo às normas e à fé dos arianos, de que foi adepto Santo Agostinho ${ }^{297}$. Quando chegaram a conquistar a

\footnotetext{
295 “Gentis”, no sentido de “idólatras”, “pagãos”, à maneira como os cristãos nomeavam as populações que ainda não entraram em contato com a revelação cristã.

${ }^{296}$ Em português, Apúlia: região meridional da Itália.

297 Engano de João Leão Africano. Na tradução espanhola de Serafín Fanjul há uma pequena nota que ressalta o erro do autor, mas seguido de uma explicação curta que apenas pontua a discordância de Santo Agostinho com as ideias do cristianismo ariano. O Arianismo foi uma vertente cristã difundida pelo religioso egípcio Arius que nega a consubstanciação entre Deus e Jesus. Para os arianos, Jesus como homem, tem uma natureza diferente de Deus, o que estabelece um confronto direto do Arianismo com o dogma católico da Santíssima Trindade. Santo Agostinho chegou a elaborar um tratado teológico em discordância direta com o pensamento cristão ariano, chamado De Trinitate libri XV, entre 399 e 422 d.C.
} 
Berberia, os árabes se encontraram com os cristãos, que eram donos e senhores daquela região, com quem travaram muitas batalhas, querendo Deus, enfim, dar aos árabes a vitória e fazer com que os arianos fugissem para as terras da Itália e da Espanha. Mas depois da morte de Maomé, cerca de duzentos anos depois, quase toda a Berberia tornou-se maometana. É verdade que muitas vezes essas pessoas se rebelaram, e negando a fé de Maomé assassinaram seus sacerdotes e governadores, mas os pontífices mandavam exércitos contra esses rebeldes. Chegados à Berberia os cismáticos fugidos dos pontífices de Bagdá, a fé de Maomé firmou-se nessas terras, com heresias e diferenças que ainda persistem. Mas, da lei de Maomé, ou seja, de suas coisas de maior importância, e da diversidade ente africanos e os da Ásia, com o favor de Deus, eu penso tratá-lo em outra obra, uma vez terminada esta.

\section{As letras utilizadas pelos africanos.}

Os historiadores árabes tem a firme opinião de que os africanos não tiveram outra sorte de letra que a latina, e dizem que quando os árabes dominaram a África, principalmente a Berberia, onde estava a civilização da África não encontraram outra letra, senão a latina. Dizem que os africanos possuem uma língua diferente e própria, mas que usam comumente as letras latinas, como na Europa fazem os tudescos. Quantas histórias tem os árabes sobre os africanos, estão traduzidas da língua latina: trabalhos antigos, algumas escritas no tempo dos arianos, outras posteriormente, e os autores aquelas são nomeados, mas esses nomes não estão mais na minha mente. Penso que estes tais trabalhos são muito longos, porque seus interpretes dizem rotineiramente: tal coisa está contida em setenta livros. A verdade é que os árabes não traduziram ditas obras de acordo com as ordens dos autores, mas organizaram um quadro sumário dos soberanos a partir do qual classificaram e dividiram os períodos correspondentes a estes senhores e príncipes em concordância com a cronologia dos reis da Pérsia, Assíria, ou da Caldeia, ou de Israel. E no tempo em que os cismáticos reinaram na África, os que fugiram do pontífice de Bagdá, mandaram queimar todos os livros de história e ciência dos africanos, porque parecia que esses livros alimentavam a antiga soberba africana, e que favoreciam a rebeldia e a abjuração da fé de Maomé. Alguns de nossos historiadores dizem que os africanos possuíam escritas próprias e que as perderam com a dominação romana na Berberia, seguida do longo tempo em que foram subordinados aos cristãos 
fugidos da Itália, e aos godos, Tiveram então os africanos que seguir os costumes de seus senhores, se quisessem agradá-los, tal como sucedeu com os persas submetidos aos árabes, os quais perderam seus escritos; todos queimados por ordem do pontífice maometano. Acreditava-se que enquanto os persas tivessem livros contendo as ciências naturais, as leis e a fé em seus ídolos, não poderiam ser bons católicos e maometanos. Queimaram, portanto, as suas obras, proibiram suas ciências de forma semelhante ao que fizeram romanos e godos quando, como foi dito, senhorearam a Berberia. Creio que, para dar testemunho disto, bastaria dizer que em toda a Berberia, tanto nas cidades litorâneas como nas do interior, isto é, aquelas que foram antigamente edificadas, todos os epitáfios presentes nas sepulturas, ou as inscrições dos muros de qualquer edifício, tudo está escrito em latim e em nenhuma outra língua. Não por isso eu negaria que os africanos tiveram sua própria escrita, porque não se pode duvidar que quando os romanos, que foram seus inimigos, dominaram aquele lugar, como é costume dos vencedores pelo seu desprezo, substituíram os títulos e escritos pelos seus próprios, para remover juntamente com a dignidade dos africanos a sua memória, fazendo imperar somente a do povo romano. Da mesma maneira procederam os godos com os romanos, os árabes com os persas e, hoje em dia, os turcos com lugares cristãos que conquistam, estragando não somente belas e honoráveis memórias, mas também imagens de santos e santas que encontram. Mas mesmo em Roma pode-se ver em nossos tempos, que um belo e digno edifício começado por um senhor com grande gasto, e por sua morte deixado imcompleto; o sucessor o demolirá até as bases para fazer uma nova construção; e se deixa-o em pé, com poucas novidades a serem incorporadas, já quer que desapareça as armas daquele senhor para colocar as suas próprias, ou deixa a sua dominando a do antecessor e em um lugar melhor e mais honrado. Não é de maravilharse que as letras africanas tenham se perdido, e há novecentos anos os africanos usem a escrita árabe. Ibnu Rachic ${ }^{298}$, escritor africano, em sua crônica faz dessa questão uma longa controvérsia, qual seja, se os africanos tinham escrita própria ou não, e conclui que tinham, dizendo que quem o nega, pode igualmente negar que os africanos tivessem uma língua própria, acrescentando ainda que é impossível que um povo que tenha uma língua particular, utilize para escrever uma escrita estranha.

\footnotetext{
${ }^{298}$ Abū Isḥāq Ibrāhīm ibn al-Qāsim ar-Raqīq al-Qayrawānī (COLOCAR CARACTERES ÁRABES): escritor e cronista do século XI que viveu na corte da dinastia berbere dos Zirida, na atual Tunísia. É autor de importante obra sobre a história do Magrebe, sendo citado por importantes autores islâmicos posteriores como Ibn Khaldun.
} 


\section{Regiões da África.}

A África está dividida em quatro partes, sendo que essas partes encontram-se em lugares diferentes. A costa do Mar Mediterrâneo, desde o estreito de Gibraltar até os confins do Egito, é toda marcada por montanhas, que se alarga em direção ao meio-dia cerca de cem milhas, porém em alguns lugares mais do que em outros. Desde estes montes até o Atlas estendem-se planícies e algumas colinas pequenas, e por todos os montes da costa se encontram muitas fontes, que logo se convertem em riachos claros, agradáveis e deleitosos aos olhos. Depois deles, mais planícies, colinas e os montes Atlas, que surgem do mar Oceana, ou seja, da parte do poente e se estende em direção ao levante e aos confins do Egito. Após o Atlas descobrem-se as planícies onde está a Numidia e nascem os dátiles, uma terra quase toda de areia. Passada a Numidia estão os desertos da Líbia, igualmente arenosos até a Terra dos Negros. Contudo, ao longo destes desertos se encontram muitos montes, mas os mercadores por ali não passam, já que entre essas colinas existem muitas trechos largos e planos. Depois dos desertos da Líbia está a Terra dos Negros, a maior parte da qual é plana e arenosa, exceto a costa do rio Níger, e todos os lugares ode suas águas banham e chegam.

\section{Lugares selvagens e nevados da África.}

Toda a costa da Berberia e os montes nela contidos são mais frios e em alguma estação do ano neva. Em todos esses montes nascem grãos e frutas, mas não muito trigo, de modo que seus habitantes comem, na maior parte do ano, pão de cevada. As nascentes de água que se encontram nesses montes, possuem certa água que tem o sabor terroso e são quase turvas, principalmente na parte que faz fronteira com a Mauritânia. Crescem nesses montes grandes bosques com árvores altíssimas, cheios de animais bons e maus, mas as pequenas colinas e as planícies que estão entre os tais montes e o Atlas são todas de boníssimas terras, que produzem grande quantidade de grãos e ótimos frutos, e por todas as colinas correm os rios que nascem no Atlas e seguem em direção ao mar Mediterrâneo. Mas, nessa parte encontram-se poucos bosques e são melhores as planícies que estão entre o Atlas e o Oceano, na região do Marrocos, a província de Duccala, toda a Tedle, Temesne e Azgar, até o estreito de Gibraltar. O monte Atlas 
muito frio e estéril; produz poucos grãos e em cada parte sua há bosques escuros e densos. Nascem ali quase todos os rios da África, e as nascentes que se encontram no dito monte são extremamente frias mesmo no meio do verão, de maneira que se alguém mantivesse as mãos em suas águas durante um pequeno espaço de tempo, sem dúvidas perder-as-ia. Nem todas as partes desse monte são igualmente frias, existem alguns lugares quase temperados, onde se pode viver muito bem e que se encontram habitados, como será contado na segunda parte do nosso livro. As partes desabitadas ou são muito frias, ou muito ásperas. Aquelas que respondem por Temesne são as ásperas, e as frias dizem respeito à Mauritânia. Entretanto, os pastores de ovelhas vão nessas terras durante o verão para que pastem suas bestas, mas no inverno não é possível permanecer ali, já que sempre que a neve chega, subitamente surge um vento da parte tramontana tão danoso que mata todos os animais que se encontram nesses lugares, e muitos homens também morrem, ao passar entre a Mauritânia e a Numidia. Os mercadores de dátiles tem o costume de partir da Numidia carregados de dátiles no fim de outubro, e quando às vezes são surpreendidos pela neve, nenhum deles permanece vivo; se à noite começa a nevar, pela manhã a caravana encontra-se sepultada e afogada na neve. Não somente a caravana, mas todas as árvores ficam cobertas, de modo que não se pode ver pegada nem sinal de onde estão os corpos mortos, e eu duas vezes escapei dessa morte por milagre no tempo em que eu percorria aqueles caminhos. Acredito que vocês não se importariam de entender como ocorreu em uma dessas vezes.

Partimos juntos de Fez muitos mercadores e encontramos a caravana do mês supracitado no Atlas. No nascer do Sol começou a cair uma fria e densa neve e um grupo reduzido de árabes com dez ou doze cavalos convidaram-me a deixar a caravana e ir a um bom abrigo. Eu, não podendo recusar o convite, e temendo que fosse enganado, pensei em livrar-me ${ }^{299}$ de uma boa quantidade de dinheiro que estava comigo e enquanto eles estavam me pressionando para acompanhá-los, fingi que necessidades naturais me apertavam ${ }^{300} \mathrm{e}$, afastando-me para debaixo de uma árvore, ali, entre as pedras e o chão, escondi e assentei como melhor pude o dinheiro, marcando com diligência a árvore. Cavalgamos silenciosamente até a meia-noite, quando um deles,

\footnotetext{
${ }^{299}$ No original: "... levarmi daddosso certa quantitá di danari che mi trovava avere." O trecho "levarmi daddosso" tem, nesse caso, o sentido de "retirar", "aliviar", "livrar-se de um problema", como na expressão em português "tirar o peso das costas".

${ }^{300}$ No original: “... fingendo che'l bisogno naturale m'astringesse”. Aqui, Leão Africano simula ter um problema fisiológico para enganar os caravaneiros suspeitos. O sentido de "bisogno naturale", como "necessidade natural", deixa subentendido a artimanha do viajante para afastar-se do grupo.
} 
pensando ser a hora de fazer o que tinham em mente, que era tomar-me o dinheiro e abandonar-me a minha boa sorte, demandou-me se eu levava algum dinheiro comigo. Eu respondi que havia deixado o dinheiro na caravana a um caro e próximo parente. Não fui crível, e para saber se era verdade, despojaram-me com aquele frio até a camisa e, como não encontraram nada, começaram a rir de mim, dizendo que o haviam feito por gracejo, e para ver se eu era um homem forte, capaz de suportar o frio. Agora, seguindo o caminho sempre no escuro, e tão incômodo pelo mal tempo como pela noite, quis Deus que escutássemos o balido de muitas ovelhas, e ali conduzimos os cavalos entre bosques e altos penhascos ${ }^{301}$, de maneira que sobressaltava um perigo maior. Finalmente encontramos alguns pastores em certas grutas, os quais haviam arriado suas ovelhas com grande esforço e acendendo um bom fogo, ficaram ao redor do mesmo. Eles, como vimos, pareciam mostrar-se inicialmente com medo dos árabes ${ }^{302}$, recebidos com certo desgosto. Depois, visto o mal tempo, demonstraram-se muito corteses e receptivos, dando-nos o que tinham para comer, isto é, pão, carne e queijo. Fornecido o jantar, nos pusemos a dormir junto ao fogo, ainda assim tremendo de frio, e eu ainda mais por há pouco ter sido desnudado. Já sem os temores que tínhamos, permanecemos dois dias e duas noites com esses pastores, nos quais continuou nevando. Ao terceiro dia teve fim o mal tempo e os pastores começaram, com grande diligência, a retirar a neve que tapava a entrada da gruta. Em seguida nos conduziram para onde haviam sido deixados nossos cavalos, que estavam em outras grutas, e demos muito feno aos animais. Como os encontramos em bom estado, saímos de partida. Essa manhã o Sol claro apareceu e dissipou quase toda a friagem dos dias anteriores. Os pastores acompanharam-nos por algumas milhas, mostrando-nos pequenos caminhos em que sabiam não possuir neve muito alta, contudo, os cavalos afundaram na neve até o peito, e quando, já nos confins de Fez fomos a um povoado, nos informaram com toda a certeza que a caravana havia se afogado na neve. Agora, que os árabes haviam perdido a esperança de serem pagos por seus trabalhos, dada a ruína da cáfila que escoltavam, apoderaram-se de um judeu que estava em nossa companhia e levava cinquenta cargas de dátiles, e o levaram preso a suas tendas com a intenção de retê-lo até que ele pagasse

\footnotetext{
${ }^{301}$ Nesse caso: “... inviamo drizzando i cavalli tra boschi e alte rupi,..." Preferi ser fiel ao sentido dedutível da expressão, do que à tradução literal.

${ }^{302}$ Leão Africano chama aqui de "árabes" aos beduínos.
} 
por todos. A mim, levaram-me o cavalo e me deixaram ao acaso ${ }^{303}$. Eu fiz uso de uma mula com certo tipo de sela que usa a gente desses montes e no terceiro dia de jornada cheguei a Fez, onde achei que já havia chegado a triste notícia e o conhecimento de minha morte, o que não quis a bondade de Deus. Agora, deixando de contar minhas aventuras, retornarei a finalidade que abandonei. Do outro lado do monte Atlas encontram-se terras secas e quentes com poucos rios, os quais nascem no Atlas e, correndo em direção ao deserto da Líbia, se perdem na areia ou formam algum lago. Nessas terras existem poucos lugares bons para a semeadura, ainda que as arvores de dátiles sejam infinitas e se veja uma ou outra árvore frutífera. Nas terras limítrofes da Numidia com a Líbia existem montes acidentados e sem árvore alguma, com muitos arbustos espinhosos e sem frutos aos pés dos mesmos. Não há nascentes nem rios, senão alguns poços quase desconhecidos por toda a gente, entre os montes desérticos. Em toda a terra da Numidia existem muitos escorpiões e serpentes, de cujas mordidas e picadas morre muita gente nos verões. A Líbia é igualmente um país desertíssimo, árido e $\operatorname{arenoso}^{304}$, em que não se encontra nem nascentes, nem rios, nem água, exceto por certos poços com água bem salobra, e essas não são muitas. Alguns lugares não se encontra sequer essas águas por seis ou sete dias de caminho, devendo os mercadores transportá-las em odres junto a seus camelos, principalmente pela estrada que liga Fez a Tombutto, o de Telensin a Agadez; e muito pior é a viagem moderna de Fez ao Cairo pelo deserto da Líbia. Nesta viagem contorna-se um grandíssimo lago ao redor do qual vivem os povos de Sin e Gorran.

$\mathrm{Na}$ viagem de Fez a Tombutto encontram-se alguns poços, ou forrados por coro de camelo, ou murados com os ossos desses animais; e é de grande perigo aos mercadores essa viagem em qualquer estação que não seja o inverno, já que ali sopram certas brisas ou siroco $^{305}$ que levantam tanta areia que cobrem os citados poços, tanto que os mercadores que partem com esperança de encontrar água nos lugares costumeiros, não são capazes de discernir nem sinal, nem vestígio de poço por estarem cobertos de areia, de modo que são condenados a morrer de sede e os viajantes vem frequentemente

\footnotetext{
${ }^{303}$ No original: “... accomodarono a Dio.” A passagem sugere o sentido de que Leão Africano foi deixado a sua própria sorte, ou em uma expressão que mantém o sentido de "vontade de Deus", "a Deus dará". Para conferir melhor sentido à passagem, proponho substituir por "me deixaram ao acaso".

${ }^{304}$ No original: "... Libia é eziandio paese disertissimo, secco e tutto arena...". Ainda que termos como "desertíssimo", "árido" e "arenoso" sejam redundantes, mantenho a forma para acentuar o caráter exagerado que Leão Africano confere à referida passagem.

${ }^{305} \mathrm{O}$ "siroco" é um vento quente do sudeste do Mediterrâneo. Esse vento parte do deserto do Saara em direção ao Norte da África e Sul da Europa, onde se transforma em uma espécie de furacão. É conhecido em árabe como "qibili" (قُ بـى), e em italiano como "scirocco".
} 
branquear seus ossos ${ }^{306}$ e os de seus camelos em diversos lugares. Contra isso só existe um único e estranho remédio: matar um camelo e, espremendo suas vísceras, beber e compartilhar a água dali retirada até encontrar algum poço ou perecer de sede. Existem duas tumbas no deserto de Azaoad, feitas não sei de qual tipo de pedras e com entalhes que declaram estarem sepultados ali dois homens, um dos quais foi riquíssimo mercador, e passando por aquele deserto, infestado pela sede, pagou a um tropeiro por um copo de água cerca de dez mil ducados, e ainda assim morreu de sede ao lado do que lhe vendeu a água. Nesse deserto existem muitos animais nocivos, e outros ainda, que não são perigosos, mas de ambos falarei na quarta parte desse livro, que tratará de Líbia, em que farei particular menção aos animais que se encontram na África. Penso ainda contar sobre os perigos que passei em outras viagens e lugares da Líbia, principalmente a viagem a Gualata, que não pouca maravilha os dará. Mas voltamos agora ao fato de que nos desertos acima mencionados, perdemos mais de uma vez a estrada para encontrar água, nos escapava a direção, a areia escondia os poços, ou inimigos controlavam os caminhos para a água. Foi necessário racionar a pouca água que encontramos o melhor que podíamos, compartindo aquela parte que deveria dar para beber por cinco dias, para um maior número. Mas, se eu quisesse detalhar a particularidade de uma única viagem, não seria necessário escrever sobre outra. Na Terra dos Negros, suas províncias ${ }^{307}$ são extremamente quentes e úmidas por causa do rio Níger, e todas as regiões que são vizinhas ao referido rio possuem excelente terras, nas quais nascem grandíssima quantidade de grãos e infinito número de bestas, porém sem frutas de nenhuma sorte, exceto algumas frutas produzidas por árvores bem grandes e que se assemelham as castanhas, mesmo que mais amargas. Essas árvores estão mais distanciadas do rio, em terras interioranas. $O$ fruto que menciono aqui é chamado na língua deles de goro $^{308}$. É verdade que há também em quantidade, abóboras, pepinos,

\footnotetext{
${ }^{306}$ No original: "e sovente da viandati si veggono l'ossa loro e de loro camelli biancheggiare in diversi luoghi." O sentido da passagem: "branquear seus ossos e os de seus camelos", sugere que se trate de uma expressão referente à exposição à morte do viajante e de seus animais. Porém, não foi possível confirmála. O cotejo com outras traduções como a francesa e a espanhola anteriormente citadas, não resolve a questão, já que os tradutores preferiram a tradução literal da frase. Por essa razão, prefiro não sugerir no corpo do texto, o sentido não comprovado, repetindo a estratégia dos demais tradutores de manter o significado literal da frase.

${ }^{307}$ No original: "Nella Terranegra sono i paesi caldissimi..." Destaco aqui o fato de que Leão Africano chama de "países", as diferentes partes de um dado território. Esse uso do vocábulo "país" é completamente apropriado ao modo como o conceito é entendido no século XVI.

${ }^{308}$ Goro é a forma árabe para uma variação da noz-de-cola, podendo ser tanto a Cola nitida, quanto a Cola acuminata. Os diversos nomes que a fruta possui em línguas distintas dificultam a confirmação da especificidade descrita por Leão Africano. No comércio internacional, o goro pode ser conhecido como gbanja cola, goro cola, labozhi (labuje), kola. Em português, é conhecida como coleira, noz-de-cola,
} 
cebolas e outros frutos. Nem ao longo de toda a costa do Níger, nem ainda nos confins da Líbia se encontra montanha ou colina alguma. Em contrapartida, há muitos lagos formados pela inundação do Níger, e em torno deles existem muitos bosques nos quais habitam elefantes e outros animais, como especificamente a seu tempo será dito.

\section{Movimentos naturais do ar na África, e a diversidade proveniente deles.}

Em quase toda a Berberia, passada a metade de outubro tem início o período de chuva e frio, começando em dezembro e ficando o frio maior em janeiro, como em outros lugares, mas ali somente pela manhã, de modo que a ninguém se faz necessário esquentar-se ao fogo. Em fevereiro geralmente faz menos frio, mas em um único dia o tempo pode mudar cinco ou seis vezes. Em março sopram impetuosamente ventos do poente e da Tramontana, e este fecunda a terra e faz florescer as árvores, e em abril quase todas as frutas começam a ganhar corpo, enquanto que nas planícies da Mauritânia em princípios de maio, e começado em fins de abril, comem-se cerejas, e na terceira semana de maio se colhem os figos maduros, como no verão, e na terceira semana de junho começa a amadurecer a uva. As maçãs, as peras, abricós, e ameixas amadurecem entre junho e julho. Os figos de outono estão maduros em agosto, assim como as jujubas, mas em setembro é a vez dos figos e dos pêssegos ${ }^{309}$. Passado meados de agosto começa a secagem das uvas ao Sol, e se chove em setembro,com toda a uva remanescente faz-se vinhos e mostos cozidos, principalmente na provincia de Rif, como

abajá, café-do-sudão, cola, obi, oribi ou orobó), dependendo da espécie. No Brasil, essa fruta é conhecida pelo uso sagrado que possui em determinados rituais do candomblé. Possui alta concentração de alcaloides como a cafeína e a teobromina, servindo de estimulante. Para mais informações: Paul.E. Lovejoy. Kola in the history of West Africa. Cahiers d'études africaines, v. 20, n. 77, p. 97-134, 1980. Além de Laurie E. Clark et Terry C. H. Sunderland. Forest Productsof Central Africa: State of knowledge. Technical Paper no. 122. Maio, 2004.

http://terrysunderland.com/_asset/berkas/The_Key_Non-

Timber_Forest_Products_of_Central_Africa\%3A_State_of_the_Knowledge-190611.pdf

309 Possivelmente ao mencionar a "jujuba", trata-se da Ziziphus jujubas, ou Ziziphus zizyphus, Ziziphus lótus, e Ziziphus mauritiana; também conhecida em português como açofeifa ou açofaifa. Em língua italiana, o fruto é conhecido como "giuggiolo", e por isso, chama a atenção o fato de Leão Africano optar pela forma comparativa ao aproximar o tempo de amadurecimento da fruta ao do "figo de outono". Podese deduzir que a citada fruta não era desconhecida por Leão Africano, já que sua denominação mais difundida na região ocidental do Mediterrâneo é "azufaifa" com corruptelas possíveis originários do árabe e do castelhano. Assim, o destaque que Leão Africano confere à fruta pode servir como sinal de que para o viajante existe um potencial comercial nesse produto, já que a precisão em denominá-la é comparável a de outras frutas mais difundidas e exploradas economicamente na Europa, como as maçãs e as uvas. Com relação ao figo, parece que Leão Africano comete um equívoco. Inicialmente ele anuncia que o "figo de outono" amadurece em agosto, e depois reafirma que o "figo", simplesmente, amadurece em setembro. Existem duas especulações possíveis aqui: ou Leão Africano entende "figo de outono" e "figo" como duas frutas distintas, ou trata-se da mesma fruta com duas possibilidades de colheita. 
também se dirá posteriormente. Em meados de outubro colhem-se as maçãs, as romãs e os marmelos; em novembro as azeitonas, que nao sao colhidas com escadas, como se faz na Europa, retirando-as com as mãos, pois nao se pode fazer escadas tao longas capazes de chegar à altura dessas árvores; com o que quero dizer que ali as oliveiras são muito grossas e altíssimas, especialmente as da Mauritânia e da Cesari; ao contrário, as do reino de Tunis se assemelham as que nascem em Europa. Portanto, quando os homens vao colher as azeitonas, subem nas árvores com bastões longuíssimos nas mãos, e batendos nas ramas, fazem os frutos cairem, coisa que danifica as oliveiras ao estragar muitos brotos jovens. Ainda se verifica que as oliveiras da África são abundantes em certos anos, e em outros nao se encontra senão certo tipo mais grosso, que nao são bons para se extrair o óleo; mas se come condimentado, seja qual for a estação do ano.

\section{Condições e características ao longo do ano.}

Os três meses da primavera sao sempre temperados. Entra a primavera no quinze de fevereiro, e acaba no dezoito de maio, e em todas estas estações nao cessa o bom tempo;mas se nao chove de vinte e cinco de abril até cinco de maio, a colheita do ano será péssima. Chama-se as água desse período de "água de Naisan ${ }^{310, ", ~ a ~ q u a l ~ t a m b e ́ m ~}$ tem-se por abençoada água de Deus. Muitos guardam essa água em frascos e ampolas, tendo-as em casa por devoção. O verão dura até dezesseis de agosto e durante todo esse tempo faz muito calor, especialmente em junho e em julho, e todo esse tempo é sereno e faz bom ar, exceto em algum ano em que, se chove em julho ou agosto, dessas aguas advem maus ares que fazem muitos enfermarem de uma aguda e contínua febre, e poucos são os que escapam dela. A estação do outono começa em dezessete de agosto e segue até dezesseis de novembro, e estes dois meses, de agosto e setembro, são de menor calor. Entretanto, alguns dias que avançam entre quinze de agosto e quinze de setembro sao chamados pelos antigos de "forno do tempo", pois em agosto amadurecem os figos, romãs, marmelos, e seca a uva. Em quinze de novembro começa a estação do inverno, e se estende até quatorze de fevereiro e, ao seu início começa a semeadura das terras planas, enquanto que nos montes se faz em outubro. Os africanos tem a opinião

\footnotetext{
310 "Naisan" refere-se a "Nisan" em árabe (ند): o mês de abril. As "águas de Nisan" são o correspondente local às "águas de março" típicas do sudeste brasileiro. O Fim do verão brasileiro é marcado por chuvas fortes no mês de março. A referência para o Norte da África é o período chuvoso que a região possui no mês de abril.
} 
de que em um ano são quarenta dias de muito calor, que costumam começar em doze de junho, assim como creem em outros tantos dias de muito frio, que começam em doze de dezembro. Seus equinócios começam (e assim é) em dezesseis de março e dezesseis de setembro, voltando o Sol no dia dezesseis de junho e no dezesseis de dezembro.

Regula-se com isso os arrendamentos das propriedades, a semeadura e a colheita, bem como a navegação, a medição, e revolução dos planetas $^{311}$, e essas coisas relevantes e muito úteis são ensinadas com diligência nas escolas às crianças. Existem ainda muitos camponeses, árabes e outros que, sem haver aprendido as letras, algo sabem falar sobre astrologia copiosamente, alegando daquilo que dizem, fundamentação evidentíssima. Essas regras e orientações foram tomados da língua latina, e traduzidos para a árabe, motivo pelo qual chamam os meses do ano pelo mesmo nome usado pelos latinos. Possuem igualmente un grande livro, dividido em três partes, que chamam em sua própria língua de $O$ Tesouro dos Agricultores, traduzido da língua latina para a árabe em Córdoba no tempo de Mansor, senhor de Granada ${ }^{312}$. Essa obra trata de todas as coisas que são necessárias saber sobre agricultura, iso é, do tempo e do modo de semear, plantar, enxertar as árvores, cuidar de frutos, grãos ou legumes. Maravilha-me muito que haja entre os africanos tantos livros traduzidos da língua latina, os quais hoje não se encontra entre os próprios latinos. As considerações e normas dos africanos, e também de todos os maometanos, no que se refere a sua fé e leis, são baseados na lua ${ }^{313}$, e seu ano é de trezentos e cinquenta e quatro dias, já que possuem seis meses de trinta dias e outros seis de vinte e nove, os quais, juntos, somam essa quantia. As festas e jejuns

\footnotetext{
${ }^{311}$ Ao se referir ao movimento dos astros, Leão Africano utiliza o vocábulo "revoluzion": uma corruptela do termo italiano "revoluzione", traduzível como revolução. Para que fique clara a aplicação do citado vocábulo na frase mencionada, cabe separar o sentido do conceito de revolução na contemporaneidade, de sua acepção moderna original. De acordo com Hanna Arendt: “A palavra 'revolução', originalmente, era um termo astronômico que ganhou importância nas ciências naturais graças a De revolutionibus orbium coelestium, de Copérnico. Nesse uso científico, ela manteve seu significado latino exato, designando o movimento regular e necessário dos astros em suas órbitas, o qual, por estar sabidamente fora do alcance do homem e sendo por isso irresistível, certamente não se caracteriza pela novidade nem pela violência. Muito pelo contrário, a palavra indica com toda clareza um movimento cíclico e recorrente; é a tradução latina perfeita da $\alpha v \alpha \kappa \cup \kappa \lambda \omega \sigma ı \varsigma$ de Políbio, termo que também se originou na astronomia e era utilizado metaforicamente no campo da política." Hanna Arendt. Sobre a revolução. São Paulo: Companhia das Letras, 2011.p. 72.

${ }^{312}$ Nova imprecisão de Leão Africano. Não houve nenhum califa de Granada chamado al-Mansur (714775). Por sua origem granadina, dificilmente o autor confundiria o nome de um califa de Granada com alMansur, soberano do califado abássida do século VIII. Desse modo, Leão Africano está se referindo a outro personagem com o mesmo nome; possivelmente al-Mansur (938 - 1002), líder militar de alAndaluz. Serafin Fanjul afirma que a imprecisão não está no nome do personagem, mas no topônimo, já que nesse caso: "la metonimia es evidente: Granada por todo al-Andaluz. Como es sabido, Almanzor no fue Rey sino primer ministro de Hisham II". Serafin Fanjul. op. cit, p. 128.

${ }^{313}$ Nesse caso, nas fases da lua.
} 
caem em datas diversas. $\mathrm{O}$ ano árabe e africano tem onze dias a menos do que o latino, e esses onze dias fazem com que nosso ano esteja atrasado.

Há de se saber também que na última parte do outono, todo o inverno e parte da primavera são tempos tempestuosos de granizos, raios e trovões, e neva em muitos lugares da Berberia. Nesta região há três ventos: o que sopra do levante, o siroco, e o do meio-dia. Esses ventos são muito nocivos, especialmente em maio e em junho, quando estragam todos os grãos e não deixam crescer e amadurecer os frutos. A neve também causa grande dano aos cereais, ainda mais quando aparece no momento em que há o florescimento do trigo, já que às vezes a neve dura todo o dia. No monte Atlas não há mais que duas estações: de outubro a abril, todos esses meses são inverno; e de abril a fins de setembro são os meses do verão, porém, ao longo de todo o ano, em todo o cume do monte encontra-se neve continuamente. Na Numidia, as estações ocorrem com maior velocidade, porque em maio se colhe os grãos e em outubro os dátiles; na metade de setembro até janeiro é a parte mais fria do ano. Se chove em setembro, a maior parte dos dátiles são perdidos, e faz-se uma péssima colheita. Todas as terras da Numidia devem ser irrigadas para a semeadura, e se não chove no Atlas, todos os rios da Numidia ficam quase secos, de modo que não se podem irrigar as terras, e não chovendo até outubro, não há como ter esperança de semear naquele ano. Por outro lado, faltando água no mês de abril, não se pode recolher trigo dos campos. Mas quando não chove, é boa a colheita de dátiles, e os númidas estimam muito mais a coleta de dátiles do que a de trigo, isso porque ainda que fosse grandíssima a abundância de trigo, não seria suficiente para dar conta da necessidade de meio ano, mas quando a colheita de dátiles é boa, permite que o trigo não fique escasso, porque os árabes e os caravaneiros ${ }^{314}$ que executam o trabalho de comercialização de dátiles, levam consigo infinita quantidade de trigo para fazer escambo pelos dátiles. Também no deserto da Líbia, se ocorre uma mudança nas estações do ano na metade de agosto, e se as chuvas se prolongam até fins de novembro, e também por todo o mês de dezembro, por janeiro, e inícios de fevereiro, ocorre a abundância de pastos. Encontra-se por toda a Líbia muitos lagos e leite em fartura, e por essa razão os mercadores da Berberia realizam sua viagem à Terra dos Negros. Nesta terra, as estações demoram mais tempo para começar, tendo o início das chuvas em fins de julho, mas não chove muito; e essas chuvas da Terra dos Negros tem a virtude de não

\footnotetext{
${ }^{314}$ No original: "cammellieri"; negociantes de camelo, ou mercadores que se utilizam do camelo como transporte. Opto por traduzir como "caravaneiros" por adequar-se melhor ao contexto.
} 
beneficiar, nem fazer dano. Por isso, à semeadura das terras bastam as águas do Níger, que em suas cheias fazem substanciais e férteis todos aqueles campos, não diferente do que faz o Nilo no Egito. Bem é certo que em alguns montes dessa região faz-se necessária a chuva, e que o Níger enche na mesma época que o Nilo: que é em quinze de junho e dura quarenta dias, e depois vai baixando. E quando enche o Níger, pode-se percorrer com barcos quase todas as províncias da Terra dos Negros, já que agora todas as planícies, vales e depressões transformam-se em rios; mas é muito perigoso navegar com certos barcos que ali se usam, como na quinta parte dessa obra suficientemente descreverei.

\section{Brevidade e longevidade das vidas ${ }^{315}$.}

Em todas as cidades e territórios da Berberia, a idade dos homens chega a sessenta e cinco ou setenta anos e poucos ultrapassam este número. Mas encontram-se nos montes da Berberia homens que chegam a cem anos e alguns que superam essa idade. Estes possuem uma velhice galharda e forte, pois eu vi velhos de oitenta e tantos anos arando a terra, cavando as vinhas e realizando com destreza admirável todos os outros trabalhos que se faziam necessários e, mais ainda, eu vi no monte Atlas homens de oitenta anos irem à batalha, combatendo com valentia ao lado de jovens, e muitos deles permaneceram vitoriosos. Na Numidia também, que é a região dos dátiles, existem homens de longa vida, porém a esses lhes caem os dentes, e outros muitos que perdem a visão. A queda dos dentes provêm do costume de se comer dátiles, e a perda da visão ocorre porque essas terras são infestadas de um vento do levante, o qual levanta a areia para o alto, e esse pó agride muito frequentemente os olhos, e com o tempo passam a falhar. Os homens da Líbia vivem um pouco menos do que os de outras regiões, mas chegam próximos aos setenta anos saudáveis e galhardos, mas é verdade que são magros e esguios. Na terra dos Negros, são as vidas muito mais curtas do que entre outras regiões, mas seus homens estão sempre robustos e seus dentes são sempre firmes. São homens de grande luxúria, assim como os de Líbia e da Numidia. Os homens da Berberia são geralmente menos lascivos.

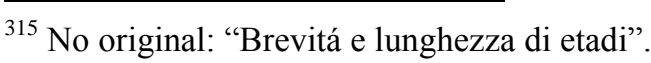




\section{Doenças mais frequentes entre os africanos.}

Nas cabeças das crianças pequenas, e também nas das mulheres de idade madura, geralmente nasce certa micose, que com grandíssimo trabalho é curada. De dores de cabeça, muitos homens são acometidos, e estas às vezes aparecem sem nenhuma febre. A dor de dente também acomete muita gente e acredita-se que ela ocorre quando se come sopa quente, seguida da ingestão de água gelada. São também incomodados por dores de estômago, as quais por ignorância chamam de "dor de coração". Torções e espasmos $^{316}$ agudíssimos atacam a muitos quase todos os dias, em razão da água gelada que bebem. A ciática e as dores de joelho são muito frequentes, procedentes do hábito de sentarem-se no chão e de não portarem calçado de nenhuma sorte. Poucos são os que padecem de gota, mas existem alguns senhores que a possuem porque são dados a beber vinho e a comer galinha e alimentos delicados. Por comer muitas azeitonas, nozes e outros alimentos fortes sem nenhum valor, são propensos ao nascimento de sarnas muito incômodas. Àqueles de natureza mais sanguínea, por sentarem-se no chão durante o inverno ficam suscetíveis a uma feroz e maligna tosse, que atrapalha muitas vezes a oração da sexta-feira; momento em que costumam ficar reunidos nos templos milhares de pessoas. Quando o sacerdote está na parte mais bonita da pregação, uma pessoa começa a tossir, seguida de outra, e gradualmente, quase todos ao mesmo tempo, de modo que ao final ninguém ouve o sermão. Da moléstia conhecida na Itália como "mal francês $^{317}$, , não acredito que em todas as cidades da Berberia, nem a décima parte de sua gente tenha escapado, e essa doença costuma apresentar-se por meio de dores, pústulas e feridas profundas, porém muitos ficam curados dela. É verdade que nos campos e no monte Atlas, quase ninguém é acometido por esse mal; Igualmente em toda a Numidia, ou seja, na região dos dátiles, não se encontra quem disso padeça, e o mesmo na Líbia ou na Terra dos Negros, cujo ar cura e deixa a todos limpos como um peixe. E eu vi com meus próprios olhos quase uma centena de pessoas que, sem outro remédio, com somente a mudança de ares foram curados. Essa doença não existia originalmente na África, nem ninguém havia ouvido sequer o nome dela, mas teve início no tempo em que Fernando, rei da Espanha, expulsou os judeus desse país, muitos dos quais vieram para a Berberia infestados desse mal, já que algumas de suas mulheres deitaram-se com infelizes mouros lascivos e se infectaram, e de um para o

\footnotetext{
${ }^{316}$ Curiosamente, Leão Africano chama esses espasmos de "passioni di corpo".

${ }^{317}$ Modo como na Itália do século XVI era conhecida a sífilis.
} 
outro foram infectando a Berberia, pois não há família que, antes ou depois, se veja livre de tal enfermidade. Além disso, como prova indubitável de que a origem dessa doença é a Espanha, está o fato de que eles a chamam de "mal da Espanha", ainda que os de Tunis a chamem de "francesa", como os italianos; entre os quais muito cruelmente a doença foi sentida durante algum tempo, como no Egito e na Síria ${ }^{318}$, onde igual nome lhe é dada. Para alguns, ainda chama-se "mal francês".

$\mathrm{Na}$ Berberia poucos padecem do mal ou defeito que os latinos chamam de hérnia, mas no Egito muitos dele se queixam. Às vezes, algumas pessoas sofrem de inchaço nos testículos, que é algo assombroso de se ver ${ }^{319}$. Acredita-se que tal enfermidade proceda do hábito de se comer certas gomas e muito queijo salgado. A epilepsia ${ }^{320}$ ataca, muitas vezes, as crianças da África; mas esses, curam-se com a idade. Sofrem desse mal também muitas mulheres, principalmente na Berberia e na Terra dos Negros, e por ignorância, acreditam que os que são afetados por essa doença estão perseguidos por espíritos $^{321}$. A peste atinge a Berberia a cada dez, quinze ou vinte e cinco anos, e leva, quando chega, grande quantidade de gente, já que não se tem nenhum cuidado com tal

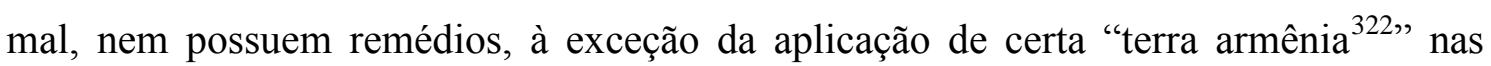
glândulas. Na Numidia não se percebe a peste a cerca de cem anos, enquanto que na Terra dos Negros nunca chegou.

\section{Virtudes e coisas louváveis entre os africanos.}

Os africanos que habitam as cidades da Berberia, e principalmente na costa do mar Meditarrâneo são homens que se deleitam com o saber, e dão muita importância aos estudos; entre eles, os de humanidades e os das coisas da fé e da lei possuem o primeiro

\footnotetext{
${ }^{318}$ No orignal: “... Egitto e in Soria...”. Deduzo que se trate da Síria. Essa interpretação também foi escolhida por Serafin Fanjul. Na versão francesa da Biblioteca Nacional Francesa, opta-se pela forma "Surie"; o que não confirma totalmente que se trate da Síria.

${ }^{319}$ Nesse caso, parece que Leão Africano confunde hérnia com orquite; uma inflamação dos testículos muito comum em vítimas de caxumba. Serafin Fanjul sugere essa confusão.

${ }^{320}$ No original "il caduco...". Sabe-se que no século XVI, a epilepsia era conhecida em diversas regiões da Itália como "mal caduco". De acordo com o Vocabolario Degli Accademici Della Crusca: "E mal caduco, diciamo l' epilessìa, perché, mancando in uno stante tutte le forze, a chi si da questo male, cadê."

${ }^{321}$ No original: "quei che sono offesi da questo male, essi gli tengono spiritati".

${ }^{322}$ Possivelmente, Leão Africano esteja se referindo ao "bolo armênio": espécie de terra argilosa caracterizada pela sua coloração vermelha e consistência oleosa. Trata-se de um silicato de alumínio composto por $25 \%$ de água. É um produto de uso recorrente em processos de restauração de obras de arte. No caso do uso dado ao termo por Leão Africano, ou trata-se de outra substância com aspecto parecido ao do bolo armênio, ou mesmo de uma aplicação rara do produto mineral.
} 
posto. Antigamente costumavam estudar disciplinas matemáticas, filosofia e astrologia, mas, nos últimos quatrocentos anos, como em parte já disse, muitas ciências foram tolhidas por seus doutores e por seus príncipes; como por exemplo, ocorrido com a filosofia e a astrologia judiciária ${ }^{323}$. Os que habitam essas cidades da África são muito devotos na sua fé, obedecendo aos seus sábios e sacerdotes, e tendo grande zelo de saber o que é necessário para essa fé. Efetuam continuamente orações ao longo do dia, suportando um fastio incrível de lavar muitos membros por causa dessas preces, e às vezes lavam todo o corpo, como eu pretendo explicar no livro segundo, sobre a fé e a lei maometanas. São, ainda, os habitantes dessas cidades da Berberia, homens engenhosos, como se vê no artifício de belos e diversos trabalhos, e são bem organizados e muito amáveis. São também homens de grande bondade, sem muita malícia; mantendo a verdade no coração e na língua, ainda que nos séculos antigos, dos quais dão fé as histórias dos escritores latinos, de outra forma teriam sido exigidos. São homens corajosos e de grande ânimo, principalmente os que habitam as montanhas. A observância de sua fé é a coisa mais importante do mundo, e primeiro preferem perder a vida à não cumprir o que prometeram. São, acima de tudo, muito ciumentos, e desprezam bastante a vida se tiverem que sofrer uma vergonha recebida por conta de suas mulheres. Ávido por riqueza e honra, levam suas mercadorias por toda a parte do mundo, e são reconhecidos por leitores e mestres em diversas ciências. São vistos cada vez mais no Egito, na Etiópia, na Arábia, na Pérsia, na Índia, na Turquia, e onde quer que vão; são muito bem vistos e respeitados, isso porque todos são perfeitos na arte que empreendem. São ainda honestos e pudicos; não dizem em público palavras desonestas. As crianças rendem honras aos mais velhos em suas argumentações, e em qualquer outra particularidade, possuem esse bom respeito, que o filho na presença do pai ou do tio não se atreve a falar nem de amor, nem de sua jovem amada, e igualmente consideram vergonhoso cantar canções amorosas, pelo mesmo respeito aos mais velhos. Se as crianças chegam a uma conversa sobre amor, subitamente se aparta daquele lugar, e tais são os bons costumes e as honestas condutas dos cidadãos da Berberia. Aqueles que vivem em tendas, que são os árabes e os pastores, são homens liberais, cheios de piedade, espirituosos, pacientes, extrovertidos, caseiros, obedientes, praticantes da fé, agradáveis, e de natureza alegre. Os habitantes das montanhas também são liberais,

323 O termo "astrologia judiciária" faz menção ao que na Idade Moderna se considerava como a capacidade dos astros de influenciar deliberadamente o destino dos homens. Com variações distintas ao longo do tempo, a maior parte dos doutores islâmicos e católicos condenou a astrologia jurídica por ser contrária à definição teológica de livre-arbítrio. 
espirituosos, pudicos, e honestos na vida comunitária. Os da Numidia são mais engenhosos, pois são dados à virtudes e aos estudos de suas leis, mas sobre as ciências naturais, não possuem muito conhecimento. São homens exercitados nas armas, igualmente valentes e benevolentes. Os habitantes da Líbia, africanos e árabes, são liberais, agradáveis, e na necessidade de um amigo, atendem-no com todo o coração. Veem de bom grado os forasteiros, e possuem um grande coração, genuíno e verdadeiro. Os negros levam uma vida boa; são fiéis, agradam aos forasteiros e dão todo o seu tempo ao prazer e a viver alegremente, dançando e estando, na maior parte do tempo festejando, em divertimentos de diversos modos. São muito francos, dedicam grandes honras aos homens doutos e religiosos. Desfrutam melhor do seu tempo do que qualquer outro africano.

\section{Vícios e coisas repreensíveis dos africanos.}

Não há dúvida de que esta gente, o quanto eles tem de virtudes, possuem igualmente de vícios; mas vejamos, mais ou menos, quais são estes vícios. Os supracitados habitantes da cidade da Berberia são pobres e soberbos, altamente insolentes, e cada pequena injúria que recebem, gravam, como se diz, em mármore ${ }^{324}$, e não a retiram da mente jamais. Ríspidos, é raro o forasteiro que possa conquistar sua amizade. São também homens simplórios, e creem nas coisas mais impossíveis. A gente comum é muito ignorante nos conhecimentos naturais, de modo que todas as ações e movimentos da natureza são tomados por atos divinos. São desorganizados em seu viver como em suas ações, sujeitos à fúrias frequentemente; na maioria de suas falas utilizam palavras presunçosas e as proferem com voz alta, sendo comum pelas ruas ver dois ou três deles se agredindo com socos. São de natureza vil, pouco apreciados por seus senhores; e pode-se dizer que um senhor tem em melhor conta um de seus animais, do que um de seus cidadãos. Não possuem nem principais, nem procuradores capazes de dirigi-los e aconselhá-los em questões acerca do governo. São também muito grosseiros e ignorantes no comércio, não tendo bancas de câmbio, nem mesmo quem transporte as mercadorias de uma cidade a outra, mas é conveniente que cada mercador esteja próximo à seus produtos por onde quer que eles circulem. Extremamente avaros,

\footnotetext{
${ }^{324}$ No original: "e ogni piccola ingiuria scrivono, come si dice, in marmo..." De forma clara, Leão Africano recorre a uma expressão idiomática para reforçar a ideia de que os habitantes da Berberia são rancorosos.
} 
encontra-se entre eles grande quantidade de homens que nunca tiveram vontade de alojar os forasteiros, nem por cortesia, nem por amor à Deus; e ainda são poucos os que retribuem alguma agrado. São sempre problemáticos, e cheios de melancolia. Não dão ouvidos a nenhuma simpatia, e isso porque estarem continuamente ocupados com as necessidades de sobrevivência, já que a pobreza é grande e seus ganhos, pequenos. Os pastores, montanheses, com os dos campos, vivem amargamente de seus trabalhos manuais, e seguem em permanente miséria e necessidade. São bestiais, ladrões e ignorantes; não pagando nada que lhes dê a crédito. São, majoritariamente cornos que de outra sorte. A todas as jovens, antes do matrimônio, é permitido ter amantes, e a gozar a fruta do amor; o próprio pai acaricia o amor de sua filha, e o irmão ao de sua irmã, de modo que nenhuma jovem entrega sua virgindade ao marido ${ }^{325}$. Também é verdade que, uma vez casada, seus amantes deixam de seguir a mulher, mas acabam entregando-se a outra. A maior parte deles não são maometanos, nem judeus, e nem mesmo creem em Cristo, pois são pessoas sem fé e não somente sem religião, mas sem sombra de religião alguma; de modo que não fazem orações, nem possuem igrejas, vivendo como bestas, e se há alguém que sinta um pouco do "odor da devoção ${ }^{326 ", ~ n a ̃ o ~}$ havendo nem lei, nem sacerdote, nem regra alguma, vê-se obrigado a viver como os demais.

Os numidas são homens distantes dos conhecimentos das coisas,e são ignorantes dos modos e ordenamentos da vida natural; são traidores, homicidas e ladrões sem resguardo ou consideração alguma. São vis, e na Berberia dedicam-se a trabalhos desprezíveis. São tratadores de cavalos, cozinheiros e serviçais de cozinha; e são capazes de qualquer ação ultrajante por dinheiro. Os da Líbia são bestiais, ignorantes, sem letras de nenhuma sorte, ladrões e assassinos; e vivem como os animais selvagens. São também sem fé e sem regra, vivendo a todo o momento na miséria. Não há traição, por maior e mais horrível que seja, que não cometam por ganância, tampouco existam

\footnotetext{
${ }^{325}$ Nessa passagem há uma dupla interpretação. Não há como garantir uma única definição para a ideia marcante que Leão Africano ressalta aqui. Considerando que o autor quer impressionar o leitor com a falta de zelo dos cidadãos da Berberia em relação ao pudor de suas mulheres, o sentido dado à palavra "l'innamorato" pode ser metafórico. Leão Africano pode estar se referindo ao fato de que os pais mimam, ou agradam, aos "amores" (amantes) de suas filhas; ou ao fato de que os pais "acariciam" o "amor" de suas filhas, ou seja: de que mantém relações sexuais com as jovens antes de seus maridos. No original: "A tutte le giovani, primaché si maritino, é lecito d'avere amanti, e di godersi de frutti d'amore; e Il padre medesimo accarezza l'innamorato della figliuola , e il fratello, della sorella." No cotejo com a tradução espanhola (Fanjul), reforça-se o primeiro sentido, enquanto que na tradução francesa (BNF) sugere-se o segundo.

${ }^{326}$ Clara alusão metafórica.
} 
animais que carreguem chifres maiores que os que sustentam essa canalha. Por toda a vida são dados a caçar, fazer mal, ou ir a guerra, e levar seus animais para pastar nos desertos; sempre descalços e desnudos. Os da Terra dos Negros são homens extremamente bestiais; homens sem razão, sem engenho, e sem prática. Não possuem conhecimento algum e vivem como animais, sem regra e sem lei. O meretrício entre eles é abundante, e, por conseguinte, os chifrudos, com exceção de alguns que habitam as cidades grandes. Esses possuem algum sentimento humano. Não me é algo vergonhoso confessar e descobrir as injúrias dos africanos, sendo a África minha criadora, onde me criei e passei os melhores e mais belos anos da minha vida, já que me arrebata a obrigação do ofício de historiador, o qual me responsabiliza por dizer sem reservas a verdade das coisas, e não a agradar o desejo de ninguém; de modo que eu sou necessariamente forçado a escrever o que escrevo, sem afastar-me em momento algum da verdade, e deixando os ornamentos da palavra e seus artifícios. Em minha defesa quero que entre os gentis espíritos e pessoas virtuosas que se dignarem a ler este meu longo trabalho, basta o exemplo de uma breve e pequena novela. Uma vez ${ }^{327}$, na minha terra de origem havia um jovem de baixa condição, de malvada e péssima vida; o qual por um pequeno furto foi condenado a ser açoitado. Chegado o dia em que teria que receber os açoites, pelas mãos do servidor da justiça, o réu descobriu que o carrasco seria um amigo seu; do qual esperava seguramente um tratamento mais respeitável do que os que os outros costumavam receber. Mas o carrasco, ao contrário, iniciando o açoitamento deu o primeiro golpe de forma muito cruel e cáustica; o qual o pobre gritou forte: _"Irmão, sendo eu teu amigo, você me trata muito mal!". O carrasco então. lhe dando uma segunda e mais forte açoitada, respondeu: _ "Parceiro, convém a mim fazer o meu ofício como se deve fazê-lo. Aqui não é lugar para amizades". Assim, seguiu dando os golpes tanto quanto foi imposto pelo juiz. Portanto, se eu me calasse diante dos vícios dos africanos, poderia cair em justa repreensão. Haveria quem acreditasse que eu o tivesse feito por sofrer também desses vícios, e que estou carente das virtudes que possuem os demais. Afirmarei também em minha defesa que me proponho a manter o costume de um pássaro, sobre cuja natureza vai tornar-se conveniente escrever outra breve e agradável novelinha.

\footnotetext{
${ }^{327}$ No original: "Ragionasi che"... Em alguns casos, a expressão "Ragionasi adunque che" pode ser traduzida como "era uma vez", ou seja, como preâmbulo de uma narrativa fabulosa ou exemplar. Por isso, optei pela forma "Uma vez...".
} 
No tempo em que os animais falavam, existiu um vago e espirituoso passarinho, dono, sobretudo, de um engenho admirável e capaz de viver sob as águas e entre os peixes, do mesmo modo que sobre a terra, como os demais pássaros. Todos os pássaros daquela época eram obrigados a dar a cada ano certo tributo ao seu rei, mas aquele passarinho resolveu não pagar nada. Nessa hora, o rei mandou um de seus oficiais para cobrar-lhe o tributo, mas o passarinho desobediente não dando como pagamento nada mais do que palavras, empreendeu grande voo ininterrupto até chegar ao mar; onde se refugiou na água. Os peixes, vendo aquela novidade, correram ao seu encontro em grande quantidade, para saber a razão que o levou a viver com eles. “_ Ai de mim! (respondeu o passarinho). Vocês, gente de bem, não sabem o mundo chegou a tal ponto, que não mais se pode viver lá em cima? O desocupado do nosso rei, por certo capricho que lhe subiu à cabeça, quer esquartejar-me vivo, apesar de minha bondade; mesmo sendo o mais puro e mais honesto cavaleiro dentre os pássaros. Pelo amor de Deus, estejam contentes com o fato de que me refugie com vocês, e possa dizer ter encontrado mais bondade entre estranhos do que em mim mesmo e entre a minha gente." Os peixes se contentaram com aquilo, permitindo que o pássaro ficasse sem nenhuma apreciação durante um ano. Ao final desse ano, o rei dos peixes, chegado o tempo de arrecadar os tributos, mandou um de seus servidores ao encontro do passarinho, fazendo-lhe entender o costume, e solicitando-lhe o seu tributo devido. "_E bem deveria ter feito", disse o pássaro, empreendendo o voo, saindo da água, deixando o servidor com a maior vergonha do mundo. Enfim, cada vez que o rei dos pássaros exigia-lhe o tributo, o pássaro fugia para a água, e quando o imposto lhe era demandado pelo rei dos peixes, ele retornava para a terra.

Quero com isso inferir que, quando o homem vê vantagem para ele, sempre a persegue o quanto pode. Desse modo, onde os africanos sejam ofendidos, direi que nasci em Granada, e não na África; e quando minha terra for vituperada, invocarei a meu favor que fui criado na África, e não em Granada. Mas, agradeçam aos africanos minha atitude favorável de contar somente as coisas que são públicas e evidentes. 


\section{ANEXO II \\ PRIMEIRO LIVRO \\ Descrizione dell'Africa di Leone Africano \\ Parte I}

1

\section{Africa onde detta.}

L'Africa nella lingua arabica è appellata Ifrichia, da faraca, verbo che nella favella degli Arabi suona quanto nella italiana "divide", e perché ella sia così detta sono due opinioni. L'una delle quali è percioché questa parte della terra è separata dalla Europa per il mar Mediterraneo e dall'Asia per il fiume del Nilo; l'altra è che questo tal nome sie derivato da Ifrico, re dell'Arabia Felice, il quale fu il primo che venisse ad abitarla. Costui, rotto in battaglia e scacciato dai re d'Assiria, non potendo far ritorno al suo regno col suo esercito velocemente passò il Nilo, e avendo dirizzato il cammino verso ponente, non si fermò prima che nelle parti vicine a Cartagine pervenne. E di qui è che gli Arabi non tengono quasi per Africa altro che la regione di Cartagine, e per tutta Africa comprendono la parte occidentale solamente.

\section{2}

\section{Termini di Africa.}

Secondo i medesimi Africani (quelli dico che hanno buona cognizione di lettere e di cosmografia) l'Africa, incominciando dai rami del lago del diserto di Gaogà, cioè da mezzogiorno, finisce dalla parte di oriente al fiume Nilo e si estende verso tramontana per insino ai piè di Egitto, cioè dove entra il Nilo nel mare Mediterraneo. Dalla parte di tramontana termina pure all'entrata del Nilo nel detto mare, estendendosi verso ponente fino allo stretto delle colonne di Ercole. Da quella di ponente si estende dal detto stretto sopra il mare Oceano fino a Nun, ultima città di Libia sul detto mare. E dalla parte del mezzogiorno comincia pure nella detta Nun e si sporge sopra l'Oceano, il quale fino ai diserti di Gaogà cinge e abbraccia tutta l'Africa. 


\section{Divisione di Africa.}

Appresso i nostri scrittori l'Africa è divisa in quattro parti, cioè in Barberia, in Numidia, in Libia e nella terra de' negri. La Barberia incomincia da oriente dal monte Meies, che è la ultima punta di Atlante, appresso Alessandria circa trecento miglia. E dalla parte di tramontana ha fine al mare Mediterraneo, pigliando il principio dal monte Meies, e si estende in fino allo stretto delle sovradette colonne di Ercole. E dalla parte di ponente il termine incomincia dal detto stretto e passa oltra sul mare Oceano fino all'ultima punta di Atlante, cioè dove ha capo dalla parte occidentale sopra l'Oceano, vicino al luogo nel quale è la città chiamata Messa. E dalla parte di mezzogiorno finisce appresso il monte Atlante e nella faccia del detto monte che riguarda il mare Mediterraneo. Questa è la più nobile parte dell'Africa, nella quale sono le città degli uomini bianchi, che per ordine di ragione e di legge si governano.

La seconda parte da' Latini è detta Numidia e dagli Arabi Biledulgerid, che sono i paesi dove nascono i datteri. Dal lato di levante incomincia da Eloacat, città discosta dall'Egitto circa cento miglia, e si estende verso ponente per insino a Nun, posta sul mare Oceano; e di verso tramontana compie al monte Atlante, cioè nella faccia che guarda verso mezzogiorno. Nella parte di mezzogiorno termina e confina nell'arena del diserto di Libia. E gli Arabi communemente chiamano i paesi che producono i datteri con un medesimo nome, percioché essi sono tutti in uno sito.

La terza parte, che nella lingua latina è appellata Libia e nell'arabica non altrimente che Sarra, cioè diserto, comincia dalla parte di oriente dal Nilo, cioè dal confino di Eloachat, e si estende verso occidente fino al mare Oceano; e dalla parte di tramontana confina con Numidia, cioè pure in quei paesi dove nasce il dattero. Dal lato di mezzogiorno confina con la terra de' negri, incominciando di verso levante dal regno di Gaogà, e si porge verso ponente insino al regno di Gualata, che è sul mare Oceano.

La quarta parte, che è la terra de' negri, dalla parte di oriente incomincia dal regno di Gaogà e procede verso occidente insino a Gualata; e dalla parte di tramontana confina con i diserti di Libia, e dal lato di mezzogiorno termina al mare Oceano: luoghi incogniti appresso di noi, ma pure molta notizia ne abbiamo da mercatanti che vengono da quella parte al regno di Tombutto. Per mezzo della terra dei negri passa il fiume detto 
Niger, il quale comincia da un diserto appellato Seu, cioè dalla parte di levante uscendo d'un lago grandissimo, e si rivolge verso ponente infino che esso entra nel mare Oceano. E secondo che affermano i nostri cosmografi, il Niger è un ramo del Nilo, il quale si perde sotto la terra e ivi esce formando quel lago. Alcuni dicono che 'l detto fiume incomincia uscire dalla parte d'occidente da certi monti e correndo verso oriente si converte in un lago. Il che non è vero, percioché noi navigammo dal regno di Tombutto dalla parte di levante scorrendo per l'acqua fino al regno di Ghinea o fino al regno di Melli, i quali due a comparazione di Tombutto sono verso ponente. E i più belli regni dei negri sono quelli che giaciono sopra il fiume Niger.

E avertite che, come vogliono i detti cosmografi, la terra de' negri che è dove il Nilo passa, cioè dalla parte di ponente, e si estende verso levante insino al mare Indico e di verso tramontana confina alcune sue parti nel mar Rosso, cioè quella parte che è fuori dello stretto dell'Arabia Felice, questa parte non esser reputata parte d'Africa per molte ragioni, che in lunge opere si contengono, e i Latini la chiamano Etiopia. Da lei vengono certi religiosi frati, i quali hanno i lor visi segnati col fuoco, e si veggono per tutta l'Europa e specialmente in Roma. Questa parte è signoreggiata da un capo a modo di imperadore, a cui gli Italiani dicono Prete Gianni. E la maggior parte di cotal regione è abitata da cristiani; nondimeno v'è un signore maumettano che molto terreno ne possede.

\section{4}

\section{Divisioni e regni delle dette quattro parti d'Africa.}

La Barberia si divide in quattro regni. Il primo è il regno di Marocco, il quale è diviso in sette regioni: ciò sono Hea, Sus, Guzula e il territorio di Marocco, Duccala, Hazcora e Tedle. Il secondo regno è Fessa, il quale sotto di lui ha altretante regioni, e queste sono Temezne, il territorio di Fez, Azgar, Elabath, Errifi, Garet, Elcauz. Il terzo regno è quello di Telensin, che ha sotto di sé tre regioni: i Monti, Tenez ed Elgezair. Il quarto regno è quello di Tunis, a cui sono sottoposte quattro regioni: Bugia, Costantina, Tripoli di Barberia, Ezzab, che è una buona parte di Numidia. La region di Bugia fu sempre in combattimento, percioché alcune volte ella fu posseduta dal re di Tunis, altre la tenne il 
re di Telensin. Vero è che a' dì nostri si fece un regno da per sé, fino a tanto che dal conte Pietro Navarro per nome di Ferrando re di Spagna fu presa la principale città.

\section{5}

\section{Divisione di Numidia, ciò̀ dei paesi dove nascono i datteri.}

Questa parte nell'Africa è men nobile di tutte l'altre, onde i nostri cosmografi non le hanno dato titolo di regno, percioché le abitazioni di lei sono molto lontane l'una dall'altra. Per cagione di esempio, Tesset città di Numidia fa cerca quattrocento fuochi, ma è discosta da ogni abitazione per li diserti di Libia cerca trecento miglia: adunque ella non merita titolo di regno. Io nondimeno vi narrerò i nomi dei terreni abitati, quantunque alcuni luoghi si truovano che sono al modo dell'altre regioni, come è lo stato di Segelmese, che è nella parte di Numidia la quale risponde verso Mauritania, e lo stato di Zeb riguardante verso il regno di Bugia, e Biledulgerid, che si estende verso il regno di Tunis. Ora, serbandomi molte cose nella seconda parte dell'Africa, incominciando dalla parte occidentale i nomi sono questi: Tesset, Guaden, Ifren, Hacca, Dare, Tebelbeth, Todga, Fercale, Segellomesse, Benigomi, Feghig, Teguat, Tsabit, Tegorarin, Mesab, Teggort, Guarghela. Zeb è provincia nella quale si contengono cinque città: queste sono Pescara, Elborgiu, Nesta, Taolacca e Deusen. Biledulgerid signoreggia altretante città: Teozar, Cafeza, Nefreoa, Elchama e Chalbiz. Doppo questa verso levante è l'isola di Gerbe, Garion, Messellata, Mestrata, Teoirraga, Gademis, Fizzan, Augela, Birdeua, Eloachet. Questi sono i nomi dei luoghi famosi di Libia incominciando dal mare Oceano, cioè, come s'è detto, dall'occidente e terminando ne' confini del Nilo.

\section{6}

\section{Divisione dei diserti che sono fra Numidia e la terra negra.}

Questi diserti appresso noi non sono appellati con nome alcuno, quantunque siano divisi in cinque parti e sia ogni parte nominata dal popolo che vi abita e in quella ha il suo vivere, cioè dai Numidi, i quali sono eziandio divisi in cinque parti. Queste sono Zanega, Guanziga, Terga, Lenta e Berdeoa. V'hanno appresso alcune campagne che 
dalla malignità o bontà del terreno particolari nomi prendono, come Azaoad, diserto così detto per la sterilità e seccaggine ch'è in lui, e Hair, diserto ancora esso, ma nomato dalla bontà e temperanza dell'aere.

\section{7}

\section{Divisione della terra negra per ciascun regno.}

Ancora la terra negra è divisa in molti regni, di quali nondimeno alcuni sono incogniti e lontani dal commerzio nostro. Per il che di quelli dirò ove sono stato io e ho avuta lunga pratica, e di quegli altri ancora da' quali partendosi i mercatanti che le lor mercanzie contrattavano nel paese dove io era, me ne diedero buona informazione. Né voglio tacer d'esser stato in quindici regni di terra negra, e tre volte più ce ne sono rimasi di quelli dove io non fui, ciascuno assai noto e vicino a' luoghi ne' quali mi trovava. I nomi di questi regni, togliendo il principio dall'occidente e seguendo verso oriente e verso mezzogiorno, sono tali: Gualata, Ghinea, Melli, Tombutto, Gago, Guber, Agadez, Cano, Casena, Zegzeg, Zanfara, Guangara, Burno, Gaogà, Nube. Questi sono quindici regni i quali per la maggior parte sono posti sul fiume Niger, e per quelli fanno la strada loro i mercatanti che partono di Gualata per andare al Cairo. Il cammino è lungo, ma molto sicuro. Sono questi regni discosti l'uno dall'altro, e dieci di loro sono o da qualche diserto dell'arena separati o dal fiume Niger. Ed è da sapere che anticamente ogni regno da per sé era posseduto da un signore, ma a' tempi nostri tutti i quindici regni sono sottoposti al dominio di tre re, cioè del re di Tombutto, e questo ne possede la maggior parte, del re di Borno, il quale ne ha la minore, e l'altra parte è in potere del re di Gaogà. Egli è vero che '1 signore di Duccala ve ne tiene pure un piccolo stato. Confinano con questi regni dalla parte di mezzogiorno molti altri regni, cioè Bito, Temiam, Dauma, Medra, Gorhan; e di loro i signori e gli abitanti sono ricchi e assai pratichi, amministrano giustizia e vi tengono buon governo. Gli altri sono di peggior condizione che le bestie. 
Dicono i cosmografi e gli scrittori delle istorie l'Africa anticamente esser stata per ogni sua parte disabitata fuori che la terra negra, e hassi per cosa certa che la Barberia e la Numidia è stata priva d'abitatori molti secoli. Quelli che vi abitano, cioè bianchi, sono appellati el barbar, nome derivato, secondo che alcuni dicono, da barbara, verbo che nella lingua loro tanto significa quanto nella italiana "mormorare". Percioché la favella degli Africani tale è appresso gli Arabi quali sono le voci degli animali, che niuno accento formano eccetto il grido. Alcuni altri vogliono che barbar sia nome replicato, percioché bar nel linguaggio arabico dinota diserto. E dicono che ne' tempi che 'l re Africo fu rotto dagli Assirii, o come si fosse dagli Etiopi, egli fuggendo verso Egitto e tuttavia essendo seguitato da' nimici, non sapendo come difendersi chiedeva alle sue genti che lo consigliassero qual partito potesse prendere per la salute loro. Al quale essi altra risposta non davano se non gridando: "el bar bar", cioè "al diserto, al diserto", volendo inferire che per loro non si conosceva altro rimedio fuori che passando il Nilo ridursi nel diserto di Africa. E questa ragione è conforme con quelli che affermano la origine degli Africani procedere dai popoli dell'Arabia Felice.

\section{Origine degli Africani.}

Cerca la origine degli Africani sono i nostri istorici non poco tra lor differenti. Alcuni dicono ch'essi discesero da' Palestini, percioché anticamente scacciati dagli Assirii fuggirono verso l'Africa, e sì come la trovarono buona e fruttifera, così vi si fermarono. Altri sono di oppenione che la origine loro venisse da' Sabei, popolo dell'Arabia Felice, come s'è detto, innanzi che fossero scacciati o dagli Assirii o dagli Etiopi. Altri vogliono che gli Africani siano stati degli abitanti di alcune parti di Asia. Onde dicono che essendo lor mossa guerra da certi loro nemici, se ne vennero fuggendo verso Grecia, la quale era a que' tempi disabitata; ma seguitandogli i nimici, essi furono costretti a passare il mare della Morea, e pervenuti in Africa quivi si fermarono, e i nimici in Grecia. Questo si dee intender solamente intorno alla origine degli Africani bianchi, cioè di quelli che abitano nella Barberia e nella Numidia. Gli Africani veramente della terra negra dipendono tutti dalla origine di Cus figliuolo di Cam, che figliuolo fu di Noè. Adunque, qual sia la differenza tra gli Africani bianchi e tra i neri, eglino tuttavia discendono quasi da una medesima origine, conciosiacosaché, se essi vennero da' 
Palestini, i Palestini medesimamente sono del legnaggio di Mesraim figliuolo di Cus, e se procedettero da' Sabei, Saba eziandio fu figliuolo di Rama, e Rama nacque pure di Cus. Sono molte altre oppenioni cerca ciò, le quali, per non esser cosa molto necessaria, mi parve di pretermettere.

\section{0}

\section{Divisione degli Africani bianchi in più popoli.}

I bianchi dell'Africa sono divisi in cinque popoli: Sanhagia, Musmuda, Zeneta, Haoara e Gumera. Musmuda abitano nel monte Atlante, cioè nella parte occidentale, incominciando da Heha insino al fiume di Servi. Abitano eziandio in quella parte del medesimo Atlante la quale riguarda verso mezzogiorno, e in tutte le pianure che v'hanno d'intorno. Questi tengono quattro provincie, le quali sono Heha, Sus, Guzula e la region di Marocco. I Gumera similmente abitano ne' monti di Mauritania, cioè ne' monti riguardanti sul mare Mediterraneo, e occupano tutta la riviera detta Rif, la quale ha principio dallo stretto delle Colonne e segue verso il levar del sole per insino a' confini del regno di Telensin, quello che da' Latini è chiamato Cesaria. Questi due popoli abitano separatamente dagli altri popoli, i quali sono communemente mescolati e sparsi per tutta l'Africa, ma si conoscono nella guisa che si conosce il natio dal forestiere, e sempre tra loro medesimi guerreggiano e stanno in continove battaglie, massimamente gli abitanti di Numidia. Dicono molti autori che questi cinque popoli sono di quelli che sogliono per loro abitazioni avere i padiglioni e le campagne. Affermano adunque che negli antichi tempi, avendo costoro fatta lunga guerra insieme, quelli che rimasero perditori, divenuti vassalli de' vincitori, furono mandati ad abitar nelle ville, e i vettoriosi si fecero padroni della campagna e là ridussero le loro magioni. E la ragione è quasi provata, percioché molti di quelli che abitano nella campagna usano la medesima lingua degli abitatori delle ville: per cagione di esempio, i Zeneti della campagna favellano nella guisa che fanno i Zeneti delle ville, e il simile aviene degli altri. I tre popoli detti di sopra dimorano nella campagna di Temesna, cioè Zeneta, Haoara, Sanhagia. Alcuna volta si stanno in pace e alcuna volta combattono aspramente, mossi mi cred'io dall'antica parzialità.

Alcuni di questi popoli ebbero regno per tutta l'Africa, come Zeneti, che furono quelli che scacciarono la casa d'Idris, dalla quale erano discesi i veri signori di Fez ed 
edificatori di questa città; la stirpe di costoro è detta Mecnasa. Venne dipoi un'altra famiglia di Zeneti di Numidia, appellata Magraoa, la quale scacciò Mecnesa del regno di che essi avevano scacciati i signori. E d'indi a poco tempo i medesimi Zeneti furono similmente scacciati da alcuni che vennero dal diserto di Numidia, e questi furono d'una prole di Zanhagi, detta Luntuna. Essi ruinorono tutta la regione di Temesna e distrussero ogni spezie di popolo che in quella si trovava, eccetto quelli che erano della origine loro, i quali posero ad abitare in Duccala. Questa cotal famiglia edificò la città di Marocco. Avvenne poi, secondo le mutazioni della fortuna, che un grande uomo nelle cose della lor fede e predicatore appresso loro molto estimato, chiamato Elmahdi, si ribellò e fatto certo trattato con gli Hargia, che furono della stirpe di Musmoda, scacciò questa famiglia di Luntuna e fecevisi signore. Doppo la morte del quale fu eletto uno dei suoi discepoli, detto Habdul Mumen da Banigueriaghel, legnaggio di Sanhagia, e rimase il regno della famiglia di costui cerca centoventi anni, la qual famiglia signoreggiò quasi tutta l'Africa. Ella poi fu privata del regno da Banimarini, che furono della famiglia di Zeneti, i quali durarono cerca centosettanta anni. Cessò il dominio per opera di Baniguatazi, stirpe di Luntuna. Questi Banimarini sempre hanno fatto guerra con Banizeijan re di Telensin, che sono della origine di Zenhagi e della stirpe di Magraoa. Guerreggiarono ancora con Hafaza i re di Tunis, i quali vennero dalla origine di Hantata, stirpe di Musmoda.

Vedesi adunque come ciascuno dei cinque popoli sono stati in travagli e hanno avuto che fare in quelle regioni. Vero è che '1 popolo di Gumera e di Haoara non ebbe mai titolo di dominio, quantunque esso abbia pure signoreggiato in alcune parti particolari, come nelle croniche degli Africani si legge, e il tempo che questo signoreggiò fu dapoi che egli entrò nella setta di Maumetto. Percioché per adietro ogni popolo tenne separatamente il suo albergo nella campagna, e ciascuno di questi popoli favoreggiava la parte loro. E avendo tra loro compartiti i lavorii necessarii al vivere umano, i padroni della campagna si danno al governo e al levamento delle bestie, gli abitatori delle ville attendono alle arti manuali e a lavorare i terreni. E tutti questi cinque popoli comunemente sono divisi in seicento stirpi, sì come nell'arboro della generazion degli Africani si contiene, di che appo loro ne fu scrittore un certo Ibnu Rachu, il quale io lessi più volte. Tengono eziandio molti istorici che 'l re il quale è oggidì di Tombutto, e quello che fu di Melli, quello di Agudez, sono della origine del popolo di Zanaga, cioè pur di quegli che abitano nel diserto. 


\section{Diversità e conformità della lingua africana.}

Tutti i cinque popoli, i quali sono divisi in centinaia di legnaggi e in migliaia di migliaia d'abitazioni, insieme si conformano in una lingua, la quale comunemente è da loro detta aquel amarig, che vuol dire "lingua nobile". E gli Arabi di Africa la chiamano lingua barberesca, che è la lingua africana natia, e questa lingua è diversa e differente dalle altre lingue. Tuttavia in essa pur truovano alcuni vocaboli della lingua araba, di maniera che alcuni gli tengono e usangli per testimonianza che gli Africani siano discesi dall'origine dei Sabei, popolo, come s'è detto, dell'Arabia Felice. Ma la parte contraria afferma che quelle voci arabe che si truovano nella detta lingua furono recate in lei dapoi che gli Arabi entrarono nell'Africa e la possederono. Ma questi popoli furono di grosso intelletto e ignoranti, intanto che niun libro lasciarono che si possa addurre in favore né dell'una né dell'altra parte. Hanno ancora qualche differenza tra loro non solo nella prononzia, ma eziandio nella significazion di molti e molti vocaboli. E quelli che sono più vicini agli Arabi e più usano la domestichezza loro, più similmente tengono de' loro vocaboli arabi nella lingua. E quasi tutto il popolo di Gumera usa la favella araba, ma corrotta, e molti della stirpe della gente di Haoara parlano pure arabico, e tuttavia corrotto; e ciò aviene per aver lunghi tempi avuta conversazione con gli Arabi.

Nella terra negra favellasi in diverse lingue, una delle quali è da lor detta sungai, e questa serve a molte regioni, come è in Gualata, in Tombutto, in Ghinea, in Melli e in Gago. L'altra lingua essi chiamano guber, la quale è usata in Guber, in Cano, in

Chesena, in Perzegzeg e in Guangra. Un'altra è tenuta nel regno di Borno ed è somigliante a quella che si costuma in Gaogà. Un'altra ve n'è ancora serbata nel regno di Nube, e questa partecipa dello arabico e del caldeo e della favella degli Egizii. Quantunque in tutte le città d'Africa, intendendo delle maritime poste sul mare Mediterraneo insino al monte Atlante, tutti quelli che vi abitano generalmente parlino nel linguaggio arabico corrotto, eccetto che in tutto il tener del regno di Marocco e in Marocco propio si favella nella lingua barberesca, e né più né meno nei terreni di Numidia, cioè fra i Numidi che sono a Mauritania e a Cesaria vicini, percioché quelli che s'accostano al regno di Tunis e al regno di Tripoli tutti universalmente tengono e usano la corrotta lingua arabica. 


\section{Arabi abitanti nelle città d'Africa.}

Nello esercito che mandò Otmen califa terzo nell'anno 400 di legira venne nell'Africa un grandissimo numero di Arabi, che furono, tra nobili e altri, dintorno a ottantamila persone; i quali sì come molte regioni acquistarono, così quasi tutti i principali e nobili tornarono alla Arabia. Rimase quivi con gli altri il general capitano dello esercito, il cui nome era Hucba Hicbnu Nafich, il quale già aveva edificata e fermata la città del Cairaoan, percioché egli stava in continuo timore che le genti della rivera di Tunis non lo tradissero, che qualche soccorso non venisse dall'isola di Sicilia e con quello gli movessero guerra. Per il che, con tutta la quantità del tesoro ch'egli acquistato si avea ritiratosi verso il diserto nella terra ferma, lontano da Cartagine cerca a centoventi miglia, fabbricò la detta città del Cairaoan e comandò a' suoi capi e ministri di quelli che seco restarono, che abitassero ne' luoghi più forti e atti alla difesa loro, e dove non v'avessero rocche e fortezze ve le edificassero. Il che fu fatto e gli Arabi, rimasi sicuri, diventarono cittadini di quel paese e si mescolarono tra gli Africani, i quali allora, perché da Italiani furono molti anni signoreggiati, la lingua italiana ritenevano, e per questa cagione seco usando e vivendo corruppero a poco a poco la loro natia araba, la quale partecipò di tutte le favelle africane: così di due diversi popoli uno se ne fermò. Vero è che gli Arabi ebbero sempre in costume e hanno tuttavia di notar la origine loro dal canto del padre, come si usa tra noi, e i Barberi fanno il somigliante, in maniera che non v'è uomo di così bassa nazione che non aggiunga al suo nome il cognome della sua origine, o arabo o barbero che egli si sia.

13

Gli Arabi che nell'Africa in luogo di case abitano nei padiglioni.

Sempre i pontefici maumettani vietarono agli Arabi di passar con le loro famiglie e con i lor padiglioni il Nilo, fino agli anni 400 di legira, nel quale ebbero licenza da un califa scismatico: e ciò per cagione che uno, che amico e vassallo era del detto califa, si ribellò e regnò nella città del Cairaoan e in tutta quasi la Barberia, doppo la morte del quale rimase per qualche tempo il regno nella casa sua. Percioché, sì come io ho letto nelle 
istorie africane, nel tempo d'Elcain califa e pontefice di quella casa essi allargarono i loro regni, e crebbe la setta loro intanto che 'l detto califa mandò un suo schiavo e consigliere, il cui nome fu Gehoar di nazion schiava, con grandissimo esercito verso ponente, il quale acquistò tutta la Barberia e la Numidia e procedette per insino alla provincia di Sus, riscotendo i tributi e l'utile dei detti regni. Il che fatto avendo, al suo signore ritornò, al quale ripose in mano l'oro e tutto quello ch'egli di questi paesi aveva tratto. Per il che il califa, avendo conosciuto il valore e veduto il felice successo di costui, fece pensiero di metterlo in una impresa maggiore e dissegliene. A cui egli rispose: "Signor mio, io ti prometto che, sì come io t'ho fatto acquistar queste regioni di ponente, così sarò cagione che avrai l'imperio di tutti i regni del levante, cioè dell'Egitto, della Soria e di tutta l'Arabia, vendicando le offese e gli oltraggi che sono stati fatti ai tuoi antecessori dalla casa di Lhabas. Né cessarò di metter la persona mia in tutte le difficultà e pericoli, per insino a tanto che io t'abbia rimesso nel seggio antico dei tuoi nobili e generosi avoli e progenitori illustri del sangue tuo". Inteso il califa l'animo e la promessa del suo vassallo, fatto uno esercito di ottantamila combattenti, lui con molto oro e con molta vettovaglia licenziò.

Partitosi adunque il fedele e animoso schiavo, drizzò lo esercito per lo diserto che è fra la Barberia e lo Egitto, né prima giunse in Alessandria che il locotenente dell'Egitto si ritirò verso Bagaded, per essere insieme con Eluir califa. Laonde Gehoar fra lo spazio di pochi giorni e con piccolo impedimento acquistò tutte le regioni dell'Egitto e della Soria. Tuttavia non dimorava senza sospetto, dubitando non il califa di Bagaded, venendone di là con gli eserciti dell'Asia, gli desse qualche grande stretta e lo riducesse a pericolo di perder le difese e gli eserciti della Barberia. Per il che si diliberò di fare una fortezza nella quale, se il bisogno occorresse, potessero ricoverarsi le genti e sostener l'impeto dei nimici. Fece adunque edificare una città tutta circondata di mura, nella quale vi faceva star di continuo uno de' più fidati a guardia con una parte del suo esercito. Alla città pose nome Elchaira, la quale poscia per l'Europa fu detta Cairo. Questa di giorno in giorno e di borghi e d'abitazioni di dentro e d'intorno è ita accrescendo, per sì fatto modo che in tutte le parti del mondo un'altra simile non si truova.

Ora Gehoar, vedendo che 'l califa di Bagaded non faceva contra di lui alcuno apparecchio di battaglia, allora avisò il suo signore come tutte le regioni per lui acquistate gli prestavano obbedienza, e che le cose erano ridotte in pace e ben difese e 
guardate. Perciò, quando paresse alla sua felicità di trasferirsi con la persona nello Egitto, valerebbe più la presenza di lui allo acquisto di ciò che restava, che centinaia di migliaia di combattenti, e sarebbe cagione che 'l califa di Bagaded lasciando il ponteficato e il regno se ne fuggisse. Come questa bella e magnanima esortazione pervenne all'orecchie del signore, esso, senza altrimente considerare a quello che potrebbe avenire in contrario, insuperbito dalle lusinghe della seconda fortuna preparò un grosso esercito e partissi, lasciando per governatore e general capitano di tutta la Barberia un principe del popolo di Zanhagia, il quale gli era non pure amico, ma domestico servitore. Subito che 'l califa giunse al Cairo, ricevuto riverentemente dal suo schiavo, indrizzando l'animo a grandi imprese espedì grande esercito contra il califa di Bagaded. Avenne fra tanto che 'l governatore da lui lasciato della Barberia gli si ribellò e offerse obbedienza al califa di Bagaded, il quale, di ciò allegro, gli mandò larghi privilegi e fecelo re di tutta l'Africa. Questo nel Cairo inteso da Elchain, l'ebbe per amarissima novella, parte perché egli si trovava fuori del suo regno e parte perché aveva consumato tutta la quantità dell'oro e delle cose opportune ch'egli aveva portato seco; né sapendo a che partito appigliarsi spesse volte malediceva il consiglio del suo vassallo.

Era appresso di lui un suo secretario, dotto uomo e di bello e pronto intelletto, il quale, sentendo il ramarico del signore e antiveggendo la repentina rovina che soprastava al suo capo se presto riparo non se li poneva, lo cominciò a confortare e a consigliare in queste parole: "Signore, i mutamenti della fortuna sono varii, né perciò vi dovete voi diffidar della vostra virtù per lo nuovo accidente da lei avenuto: percioché, quando voi vorrete accostarvi a quello che io, che fedelissimo vi sono, bene e lealmente saprò consigliarvi, io non dubito che non riabbiate in brevissimo tempo tutto quello che per ribellione è stato da voi alienato, e appresso non otteniate l'intento vostro. Il che farete senza pagar soldato niuno, anzi io voglio che più tosto lo esercito che vi porrò nelle mani paghi voi, per le cagioni che io vi dirò". Il signore ciò udendo si rallegrò, e domandollo in che modo questo si potesse fare. Ed egli allora seguitò: "Signor mio, voi dovete sapere che gli Arabi sono accresciuti in tanto numero che oggimai l'Arabia non gli può caper tutti, e le rendite a pena non sono bastevoli per le loro bestie, percioché la sterilità è grande, ed essi non solamente patiscono disagio d'abitazioni, ma di vivere ancora. Per il che spesse fiate sarebbono passati nell'Africa, se a loro fosse stato concesso da voi. Date adunque a costoro licenza di poter fare questo passaggio, e io vi metterò nelle mani una gran quantità d'oro". Detto fin qui dal secretario, il signor fu 
poco lieto di questo consiglio, considerando che gli Arabi sarebbono cagione della rovina dell'Africa, in modo che non se la goderebbe né il suo ribello né egli. D'altra parte, avendo riguardo che ad ogni modo il regno era perduto, giudicò che fosse men male a toccare una buona quantità di danari, sì come colui gli prometteva, e insieme vendicarsi del suo nimico, che perder parimente l'una cosa e l'altra. Disse adunque al consigliere che egli facesse fare uno bando, che a ciascun Arabo che volesse pagare un ducato e non più per testa fosse lecito di passar nell'Africa con libera e larga licenza, ma sotto obligazione e giuramento d'esser nimici del detto suo ribello. Il che fatto, si messe a questo passaggio cerca dieci lignaggi di Arabi, che fu la metà dell'Arabia Diserta; vi fu ancora alcuna stirpe di quegli dell'Arabia Felice. Il numero di coloro che erano atti a combattere fu intorno a cinquantamila; le donne, i fanciulli e le bestie furono quasi infiniti. Del che fu tenuto diligente conto da Ibnu Rachic, istorico africano di cui di sopra dicemmo.

Ora fra pochi giorni gli Arabi, avendo passato il diserto che abbiam detto esser tra l'Egitto e la Barberia, prima si fermarono all'assedio di Tripoli di Barberia ed entrarono nella città per forza e la saccheggiarono, occidendo tutti quelli che occider poterono; di qui se n'andarono a Cabis città e la distrussero. Finalmente assediarono Elcairaoan, nella qual città il ribello, avendosi provisto di vettovaglie e di quanto facea bisogno, sostenne assai bene l'assedio otto mesi, in capo dei quali presero la città per forza e la saccheggiarono, e lui doppo molti strazii ammazzarono. Divisero poi gli Arabi tra loro quelle campagne e in esse abitarono, imponendo per ciascuna città gravissime taglie e gravezze.

Così rimasero signori di tutto il circuito dell'Africa per insino a tanto che successe nel regno di Marocco Iusef figliuolo di Ieffin, che fu primo re di Marocco. Costui con tutto il suo potere si rivolse a dare aiuto a quanti erano o parenti o amici del morto ribello, né cessò prima che levò dalle città il dominio degli Arabi. Gli Arabi tuttavia dimoravano nelle campagne, assassinando e rubbando ciò che potevano. In tanto i parenti del ribello regnavano in diversi luochi. Ma succedendo al regno di Marocco Mansor, quarto re e pontefice della setta del Muoachedin, sì come i suoi antecessori erano stati in favore dei parenti del ribello e gli avevano tornati in stato, così egli ebbe in animo d'esser loro contra e di torgli il dominio di mano. Per il che, astutamente composta con loro la pace, indusse gli Arabi a far lor guerra, e vennegli fatto con poca difficultà il vincergli. Mansor dipoi condusse seco tutti i maggiori e principali degli 
Arabi nei regni di ponente, e diè a' più nobili per loro abitazione Duccala e Azgar; a quegli che di minor condizione erano assegnò Numidia. Ma in processo di tempo questi, che erano sì come schiavi di Numidi, ricovrarono la loro libertà e a mal grado loro dominarono quella parte di Numidia nella quale diede loro l'abitazione Mansor, e ogni giorno i confini allargavano. Quelli che abitarono Azgar e alcuni altri luoghi in Mauritania tutti furono ridotti alla servitù, percioché gli Arabi fuora del diserto sono come i pesci fuori dell'acqua. Sarebbono bene essi volentieri andati ai diserti, ma loro vietava il passo il monte Atlante, tenuto e posseduto da Barberi. D'altra parte non potevano uscire per la campagna, percioché di lei gli altri Arabi erano padroni. Laonde, ponendo giù la superbia, si diedero a pascolar le bestie e a lavorare il terreno, pure abitando, invece di pagliai e di case rusticane, ne' padiglioni. S'aggiunse alla loro miseria esser tenuti di pagare ciascun anno ai re di Mauritania certi tributi. Quelli di Duccala, aiutati dalla loro moltitudine, furono liberi da ogni tributo.

Una parte d'Arabi era rimasa in Tunis, percioché il Mansor aveva rifiutato di menargli seco. Questi, venuto a morte Mansor, presero Tunis e di quelle regioni s'impatroniron. E durò il dominio loro per insino a tanto che si sollevarono alcuni della famiglia di Abu Haf, co' quali gli Arabi s'accordarono di lasciar loro la signoria, con questo che lor dessero la metà dei tributi e dei frutti che si cavavano del regno. Il qual patto e accordo dura per fino a' nostri dì; ma i re di Tunis non gli possono contentar tutti, percioché è maggior la moltitudine degli Arabi che l'entrata e l'utile di tutto il regno. Onde, compartendone a una parte, questa è obligata di tener pacifica la campagna, il che fa, e non noce a niuno. Gli altri, che di tal provisione sono privi, si danno alle rapine, alle occisioni e al peggio che ponno, e stanno le più volte imboscati: come passa un viandante sbucano fuori, e spogliatolo e di drappi e di danari l'amazzano, di maniera che mai non si trova la via sicura. E i mercadanti che vogliono andar da Tunis a qualche loco loro opportuno menano seco per loro sicurtà una compagnia d'archibugieri, e passano tuttavia per due non piccole difficultà: l'una è di pagare agli Arabi provigionati dai re una grossissima gabella; l'altra peggiore assai è che il più delle volte sono assaliti da quest'altri Arabi, e talvolta, non giovando la difesa che seco menano, sono ad un medesimo tempo spogliati dell'avere e della vita. 
Divisione degli Arabi venuti ad abitar nell'Africa, i quali sono detti Arabi barberi.

Gli Arabi ch'entrarono nell'Africa sono tre popoli: il primo si dimanda Chachin, il secondo è appellato Hilel e il terzo dicono Mahchil. Chachin si divide in tre lignaggi: Etbegi, Sumait e Sahid. Etbegi eziandio si divide in tre parti: Dellegi, Elmuntefig e Sobair, e queste parti si dividono in infinite generazioni. Hilel ancora è diviso in quattro: Benihemir, Rieh, Sufien e Chusain; e Benihemir si parte in Huroa, Hucba, Habru, Muslim; e Rieh in Deuuad, Suaid, Asgeh, Elcherith, Enedr e Garfa; e queste sei parti si dividono similmente in infinite generazioni. Mahchil si divide in tre: Mactar, Hutmen e Hassan. Mactar si divide in Ruche e Selim. Hutmen si divide in altretante: Elhasin e Chinana. Hassan si divide in Deuihessen, Deuimansor, Deuihubaidulla; Deuihessen in Dulein, Uodei, Berbus, Racmen e Hamr; Deuimansor in Hemrun, Menebbe, Husein e Abulhusein; Deuihubeidulla eziandio si divide in Garagi, Hedegi, Tehleb e Geoan. E tutte queste sono divise in infinite, delle quali sarebbe cosa non pur difficile, ma impossibile a ricordarsi.

15

\section{Divisione delle abitazioni dei detti Arabi, e il numero loro.}

Etbegi furono i più nobili e i principali degli Arabi, e quelli quali Almansor condusse ad abitare in Duccala e ancora nelle pianure di Tedle. Questi a' nostri dì molto sono stati molestati, quando dai re di Portogallo e alcuna volta dai re di Fez; e sono cerca a centomila uomini da guerra, e la metà è a cavallo. Sumait rimasero ne' diserti di Libia, i quali rispondono verso i diserti di Tripoli, e rade volte vengono alla Barberia, percioché non hanno né dominio né luogo in quella, ma stannosi sempre coi lor camelli nel diserto; e sono intorno a ottantamila atti alla milizia, e la più parte a piè. Sahid abitano similmente nei deserti di Libia; costoro sogliono tener domestichezza e conversazion nel regno di Guargala, hanno infiniti bestiami, e forniscono di carne tutte le città e luoghi che confinano coi loro diserti; ma ciò nel tempo della state, percioché il verno non si partono dal diserto. Sono di numero appresso centocinquantamila, ma pochi cavalli hanno. Dellegi abitano in diversi luoghi: la maggior parte tiene i confini di Cesaria e i confini del regno di Bugia, e questi hanno tributi dai signori loro vicini; la 
parte minore occupa nelle pianure di Acdesen i confini di Mauritania insieme col monte Atlante: questi danno tributo al re di Fez. Elmuntafic abitano nelle pianure di Azgar, e sono da' moderni chiamati Elchaluth; essi ancora danno tributo al re di Fez, e possono fare da ottomila cavalli molto bene in ordine. Sobaich, dico i maggiori e di più valore, abitano ne' confini del regno del Gezeir e sono provigionati dai re di Telensin, e hanno nella Numidia molte terre loro soggette; sono poco meno di tremila cavalli e molto pronti nella milizia. Questi ancora sogliono il verno, perché hanno molta copia di camelli, ripararsi nel diserto. L'altra parte abita nelle pianure che sono fra Sala e Mecnesa: tengono pecore e buoi, lavorano il terreno e danno tributo pure al re di Fez. Essi son da quattromila cavalli bene e ottimamente in ordine.

16

\section{Hilel popolo e l'abitazion d'esso.}

Hilel è la maggiore stirpe di questo popolo, e Benihamir, i quali abitano ne' confini del regno di Telensin e di Oran, e vanno discorrendo per lo diserto di Tegorarin. Questi sono provigionati dal re di Telensin; sono uomini di molta prodezza e molto ricchi, fanno cerca seimila cavalli belli e bene in ordine. Hurua posseggono i confini di Mustuganim: sono uomini salvatichi e ladri, e vanno male in arnese. Non si discostano dal diserto, percioché non hanno né soldo né dominio nella Barberia; fanno intorno a duomila cavalli. Hucba hanno le abitazioni loro ne' confini di Meliana, e hanno qualche poco di provisione dal re di Tenes; ma pure sono genti assassine e lontane da ogni umanità. Questi fanno cerca a millecinquecento cavalli. Habru abitano nelle pianure che sono fra Oran e Mustuganim, sono lavoratori de' campi e tributari al re di Telensin; possono essere appresso cento cavalli. Muslim abitano nel diserto di Masila, il qual si estende verso il regno di Bugia, e sono essi ancora ladri e assassini; hanno tributi da Masila e da alcune altre terre. Riech abitano ne' diserti di Libia che sono verso Costantina, e questi hanno gran dominio in una parte di Numidia; sono divisi in sei parti, sono tutti prodi nell'armi e nobili, vanno bene in ordine e sono provigionati dal re di Tunis, e compiono il numero di cinquemila cavalli. Suaid abitano nei diserti che si dilatano verso il regno di Tenes, e hanno gran riputazione e dominio; il re di Telensin dà loro provisione, sono nobili, valenti e bene in assetto d'ogni cosa. Asgeh sono soggetti di molti Arabi, e c'è gran quantità di loro che abitano in Garit insieme con Hemram 
popolo; ve n'è un'altra parte la quale abita con gli Arabi di Duccala in luogo vicino di Azefi. Elcherit abitano nelle pianure di Heli in compagnia di Saidima, e hanno tributo dal popolo di Heha; sono uomini vili e male agiati. Enedr abitano pure nella pianura di Heha. E tutti gli Arabi di Heha fanno cerca quattromila cavalli; tuttavia sono ancora essi disagiati d'arnesi. Garsa abitano in diversi luoghi, non hanno capo, e sono mescolati con altri popoli, massimamente col popolo di Manebba e di Hemram. Costoro portano i datteri da Segelmesa al regno di Fez, e d'indi traggono le vettovaglie necessarie e a Segelmesa le conducono.

17

\section{Mahchil popolo e le sue abitazioni e numero.}

Ruche, prole di Mactar, abita ne' confini dei diserti vicini a Dedes e Farcala. Questi sono poveri, percioché hanno pochi dominii; sono tuttavia valenti uomini a piè, tanto che si recano a gran vergogna che uno a piè si lasci vincere da due a cavallo, né è alcuno così tardo in camminare che non possa per suo piacere andare a paro di qualsivoglia cavallo, quantunque avesse a fornire un lungo cammino. Sono cerca cinquecento cavalli e ottomila uomini a piè, cioè da guerra. Selim abitano appresso Dara fiume, discorrono per lo diserto, sono ricchi, e una volta l'anno vanno con lor mercanzie a Tombutto. Sono eziandio favoriti dai re di quello, e in Derha hanno molti poderi e terreni copiosissimi e un numero grande di camelli; fanno quasi tremila cavalli. Elhasim abitano accanto il mare Oceano ne' confini di Messe, e sono cerca cinquecento cavalli; vanno pessimamente in ordine, e una lor parte abita in Asgar: quelli di Messe hanno la libertà, ma questi di Asgar sono sudditi al re di Fez. Chinana abitano con Elchaluth, e sono sottoposti al medesimo re di Fez; sono uomini forti e molto ben forniti; fanno duemila cavalli. Deuihessem si divide ancora in Duleim, Burbus, Uodei, Deuimansor, Deuihubeidulla. Duleim abitano nel diserto di Libia insieme con Zanaga popolo africano, e questi tali non hanno dominio né censo niuno, per il che sono poveri e gran ladri. Vengono sovente alla provincia di Dara per fare iscambio di bestie con datteri, vanno male in ordine, e sono cerca diecimila persone, quattrocento a cavallo e il resto a piè. Burbus abitano pure nel diserto di Libia, il quale è verso la provincia di Sus, e sono molti e poveri; ma hanno molti camelli e signoreggiano Tesset, la quale non basta loro per ferrare quei pochi cavalli che hanno. Uodei abitano nei diserti posti fra i Guaden e 
Gualata. Questi hanno il dominio di Guaden, e ancora certo tributo dal signore di Gualata in terra negra; sono di numero quasi infinito, percioché sono estimati quasi sessantamila buoni da guerra, ma hanno pochi cavalli. Racmen tengono il diserto vicino di Haccha; hanno ancora essi dominio, e sogliono per loro bisogne andare il verno a Tesset; sono cerca dodicimila combattenti, ma hanno similmente pochi cavalli. Hamr abitano nel diserto di Taganot, hanno qualche poco di provigione dalla communità di Tagauost, vanno discorrendo per lo diserto per insino a Nun, e sono cerca a ottomila uomini da guerra.

\section{Deuimansor.}

Dehemrun, stirpe di Deuimansor, abitano ne' diserti che riguardano a Segelmesse, discorrono per lo diserto di Libia insino a Ighid, hanno tributo dal popolo di Segelmesse, dal popolo di Todga, da quello di Tebelbet e da quello di Dara; hanno molti terreni di datteri, possono vivere a guisa di signori e stanno in gran riputazione. Questi fanno cerca tremila cavalieri. Tra loro sono di molti Arabi, uomini vili, ma hanno cavalli e abbondano di bestiame, como Garfa Esgeh. E questo popolo di Hemrum ha un'altra parte, la quale ha dominio di certi terreni e casali in Numidia e discorre fino al diserto di Fighig; e tutti quei terreni e casali le danno molti e gravi tributi. Costoro ne' tempi della state vengono a starsi nella provincia di Garit, ne' confini di Mauritania, da quella parte ch'è verso oriente. Sono uomini nobili e di somma prodezza, perciò i re di Fez sogliono quasi tutti pigliar moglie tra le lor donne, di maniera che hanno con esso loro amicizia e parentado. Menebbe abitano pure nel medesimo diserto, e tengono il dominio di Matgara e di Reteb, provincie in Numidia. Questi ancora sono uomini valenti e hanno certa provisione dal popolo di Segelmesse, e fanno cerca duomila cavalli. Husein, lignaggio ancora essi di Deuimansor, abitano fra' monti di Atlante, e hanno sotto la loro signoria molti monti abitati e città e castelli, che furon lor dati dai viceré di Marin, percioché essi, quando quei re a regnare incominciarono, diedero lor buono e perfetto aiuto. È il dominio di questi fra il regno di Fez e Segelmesse, e il capo loro tiene una città detta Garseluin. Vanno pure per lo diserto di Eddahra, e sono ricchi e prodi uomini; fanno cerca seimila cavalli; vanno ancora in lor compagnia molte volte Arabi, ma tengongli per vasalli. Abulhusein parte abitano ne' diserti di Eddahra, e hanno 
poco dominio nel diserto; ma la maggior parte di loro è a tal miseria ridotta che essi non hanno facultà niuna di potersi mantener ne' loro padiglioni nel diserto. È vero che in quel di Libia hanno fabricate certe piccole terricciuole, ma pure si vivono miseri e combattuti dalla fame e danno tributo a loro parenti.

\section{9}

\section{Deuihubeidulla.}

Charragi è una parte di Deuihubeidulla, e questi abitano nel diserto di Benegomi e di Fighig; posseggono molti terreni nella Numidia. Hanno provisione dal re di Telensin, il quale s'affatica quasi di continuo di ridurli a vita pacifica e onesta, percioché essi sono ladri e assassinano quanti aggiunger possono. Fanno cerca quattromila cavalli, e nella state hanno per costume di trasferir l'abitazion loro ne' confini di Telensin. Hedegi abitano in un diserto vicino a Telensin, il quale è detto Hangad; non hanno né dominio né provisione alcuna, ma vivono solamente d'assassinamenti e di rubberie, e sono cerca cinquecento cavalli. Tehleb abitano nella pianura di Elgezair, e vanno discorrendo per lo diserto insino a Tegdeat; hanno sotto il dominio loro la città di Elgezair e la città di Teddelles, ma ne' tempi nostri queste due città furono lor tolte da Barbarossa che faceva il re. Allora il popolo di Tehleb fu distrutto, che era nobile e molto valoroso nella milizia. Furono questi cerca tremila cavalli. Gehoan abitano separatamente, l'una parte insieme con Garagi e l'altra con Hedegi, ma sono loro come vasalli, il che sopportano con buona pazienza.

Ora voglio che sappiate che i dui primi popoli, cioè Schachim e Hilel, sono Arabi dell'Arabia Diserta discesi dalla origine d'Ismael figliuolo di Abraham, e il terzo popolo, cioè Mahchil, è dell'Arabia Felice e dipende dalla origine di Saba. E appresso i maumettani è tenuto che quegli ismaeliti siano più nobili di questi di Saba. E percioché tra loro s'è guerreggiato lungamente cerca la maggioranza della nobiltà, è avenuto che essi, così da una parte come dall'altra, hanno composti alcuni dialogi in versi ne' quali ciascuno racconta la virtù, i benefici e i buoni costumi del suo popolo. È da sapere ancora che gli antichi Arabi, i quali furono prima che nascessero gli ismaeliti, sono chiamati dagli istorici africani Arabi ariba, cioè Arabi arabici; e quegli che sono della origine d'Ismael vengono appellati Arabi mustahraba, cioè Arabi inarabati, il che tanto è quanto nella lingua degli Italiani Arabi per accidente, percioché essi non sono natii 
arabi. Gli Arabi che andorono dipoi ad abitar nell'Africa si dicono Arabi mustehgeme, il che dinota Arabi imbarberati, percioché avevano fatto l'abitazion loro con straniera nazione insino a tanto che, corrompendo la lor lingua, cangiarono costumi e diventarono barberi.

Questo è quanto m'è rimaso nella memoria dei lignaggi e division degli Africani e Arabi per dieci anni che io non ho né letto né veduto libro alcuno delle istorie loro. Ma se alcuno desidera di saperne più abbondevolmente, potrà ciò veder nell'opera di Hibnu da me sopradetto.

\section{Costumi e modi di vivere degli Africani che abitano nel diserto di Libia.}

I cinque sopradetti popoli, cioè Zenaga, Guenziga, Terga, Lemta e Berdeua, tutti sono dai Latini chiamati Numidi, e vivono a un istesso modo, il che è senza regola o ragione alcuna. L'abito loro è un pannicello stretto di lana grossa, il quale cuopre la minima parte della loro persona, e alcuno usa di portare in capo, o rivoltovi d'intorno, un drappo di tela negra quasi alla foggia di dolipano. I maggiori e principali, per esser segnalati dagli altri, portano indosso una gran camicia con le maniche larghe e fatta di tela azurra e di bambagio, la quale vien loro recata da mercatanti che vengono dalla terra negra. Non cavalcano altri animali che camelli, sopra certe selle che essi pongono nello spazio che è fra la gobba e il collo de' detti camelli. E bella cosa è a veder questi tali quando cavalcano, percioché alcuna volta mettono le gambe una sopra l'altra, e ambedue poscia sopra il collo del camello; altre volte pongono i piè in certi staffili senza staffe, e in luogo di sproni adoperano un ferro il quale è attaccato in un pezzo di legno lungo un braccio, ma con questo ferro altra parte non pungono che le spalle del camello. I camelli che sono da cavalcare hanno tutti communemente forato il naso, nella guisa che hanno alcuni bufoli che nell'Italia si trovano, e nel luogo forato sogliono mettere una capezza di cuoio, con la quale volteggiano e reggono i camelli come si fa con la briglia i cavalli. Nel dormire usano alcune stuore intessute di giunchi molto sottili, e i padiglioni sono fatti di pelo di camello e d'altre lane aspre, le quali nascono fra i graspi dei datteri. Cerca al mangiare, chi non gli ha veduti non potrebbe creder la pazienza che essi portano in sofferir la fame. Costoro non hanno in costume né di mangiar pane né cibo fatto di 
niuna sorte, ma si nutriscono del latte dei loro camelli, ed è l'usanza loro di bersi la mattina una grande scodella di quel latte, così caldo come egli esce delle camelle. La sera poi è la cena loro certa carne secca bollita in latte e in botiro, la quale come è cotta, ciascuno se ne piglia la sua parte in mano, e mangiato che hanno beono quel brodo, adoprando in ciò le mani in vece di cocchiari. Dipoi beonsi una tazza di latte, e questo è il fine della cena. E mentre dura loro il latte non si curano altrimente di acqua, massimamente la primavera, in tutto il tempo della quale si trova alcuno fra loro che non s'ha lavato né mani né viso: e questo aviene sì perché in quella stagione essi non vanno alla campagna ove è l'acqua, avendo come s'è detto il latte, e sì ancora perché i camelli, quando mangiano l'erbe, non sogliono bere acqua. La vita loro fino al dì che muoiono è posta tutta $\mathrm{o}$ in cacciare o in rubbare i camelli dei loro nimici, né si fermano in un luogo per maggiore spazio di tre o quattro giorni, il che è quanto i camelli mangiando consumano l'erba che vi si trova.

Questi, ancora che detto abbiamo che vivono senza regola e senza ragione, hanno nondimeno per ciascun dei lor popoli un principe a modo di re, al quale rendono onore e gli obbediscono assai. Ben sono ignoranti e senza cognizione non pur di lettere, ma né di arte né di virtù alcuna. E fra un popolo a gran fatica trovar si può un solo giudice che tenga ragione, di modo che, se alcuno è astretto da qualche litigio o da ricevuto spiacere, per trovare il padiglione del giudice gli convien cavalcar cinque e sei giornate. Percioché essi non danno opera agli studi, né per cagione d'imparar si vogliono dipartir dai diserti loro, e i giudici malvolentieri vengono tra questa canaglia, per non poter sopportare i costumi e i modi del vivere. Ma quei che vi vengono sono molto bene salariati, percioché danno per ciascun d'essi all'anno mille ducati, e più e meno, secondo che al povero giudicio loro paiono più e meno sufficienti. I gentili uomini di questo popolazzo portano pure in capo, com'io ho detto, un drappo negro e con una parte di quello cuoprono il viso, ascondendo ogni sua parte eccetto gli occhi: e ciò portano continuamente, laonde, quando mangiar vogliono, per ogni volta che si mettono il mangiare in bocca scuoprono la bocca, e mangiato che hanno se la tornano a coprire. Adducono esser di questo uso la ragione che, sì come è vergogna all'uomo di mandare il cibo fuora, così è vergogna quando lo mette dentro. Le lor femine sono molto compresse e carnute, ma non molto bianche. Hanno le parti di dietro pienissime e grasse, così le poppe e il petto; dove si cigne sono sottilissime. Sono donne piacevoli così in ragionar come in toccar le mani, e alle volte usano cortesia di lasciarsi baciare, 
ma è dannoso il passar più innanzi, perché mossi da sì fatte cagioni s'ammazzano l'un l'altro senza perdono niuno. $\mathrm{E}$ in cotesto sono più savi di alcuni di noi, che per modo alcuno non vogliono portar le corna. Sono ancora questi popoli molto liberali, come che per la seccaggine di que' luoghi nessuno passa per li padiglioni loro, ed essi non vengono alle strade maestre. Ma le carovane che passano per li diserti loro sono tenute di pagare ai lor principi certa gabella, la quale è per ciascuna soma di camello un pannicello, che può importare il valor d'un ducato.

Io fra gli altri con la carovana vi passai già alcuni anni, e come arrivammo sul piano di Araoan, il principe di Zanaga ci venne incontra accompagnato da cinquecento uomini, tutti sopra camelli, e fattoci pagar l'ordinario, invitò tutta la carovana a girsene con esso lui nei lor padiglioni e a dimorarvisi per cagione di riposo due o tre dì. Ma perché questi padiglioni erano fuori del nostro cammino discosti cerca ottanta miglia, e i nostri camelli erano molto carichi, per non allungar la via non volevano i mercanti accettar l'invito. E il principe, per ritenerci, dispose in tutto che i camelleri andassero con le some seguitando il camino, e che i mercatanti seco fussero al suo alloggiamento. Al quale come giunti fummo, subito il buono uomo fece amazzar molti camelli e giovani e vecchi, e insieme altretanti castrati e certi struzzi che essi per la strada aveano presi. Ma gli fu fatto intender da mercatanti che non si dee amazzar camelli, e oltre a ciò che essi non usano, massimamente nella presenza d'altrui, mangiar carne di castrati. Ed egli rispose che appresso loro si aveva per vergogna di amazzar ne conviti animali piccioli solamente, e specialmente a noi che eravamo forestieri, né più stati negli alloggiamenti loro. Mangiammo adunque di quello che ci fu posto dinanzi. La somma del convito fu di carni arroste e lesse; gli struzzi furono arrosti, e recatici alla mensa in certe teglie cariche d'erbe e di buona quantità di spezie della terra negra. Il pane era fatto di miglio e di panico, schiacciato e molto sottile. Ultimamente ci furono portati datteri in molta abbondanza e vasi grandi pieni di latte. Il signore ancora egli volle onorare il convito della sua presenza insieme con alcuni de' suoi più nobili e parenti di lui, ma da noi separati mangiarono. Fece venire ancora alcuni religiosi, e quei litterati che si trovavano a seder con lui. E mentre si mangiò niun di loro toccò mai pane, ma solo presero delle carni e del latte. Per il che accorgendosi il principe, a certi nostri atti, che noi di ciò eravamo rimasi stupefatti molto e pieni di maraviglia, ci rispose con parole piacevoli, dicendo che eglino erano nati in quegli diserti ne' quali non nasceva grano, perciò si nudrivano di quello che produceva il loro terreno, e che del grano si 
provedevano ciascun anno per onorare i forestieri che passavano di là; ma che bene era il vero che solevano mangiar del pane i giorni di certe feste solenni, sì come il dì della pasqua e i dì de' sacrifici. Ora egli ci tenne nei suoi alloggiamenti due dì sempre faccendoci carezze e onorandoci. Il terzo giorno diede licenza a tutti e volle in persona accompagnarci insino alla carovana. E vi dico con verità che le bestie che 'l signore fece occider per lo nostro mangiare valevano dieci tanti rispetto al valor delle gabelle che gli pagammo. E negli effetti e nel parlare si poteva conoscer che egli era nobile e cortese signore, quantunque né esso intendeva la nostra lingua né noi avevamo notizia della sua, e ciò che egli a noi diceva e che rispondevamo era per via d'interprete. La vita e i costumi che avete inteso di questo popolo è simigliante agli altri quattro che sono sparsi per gli altri diserti di Numidia.

\section{Vivere e costumi degli Arabi abitanti in Africa.}

Gli Arabi, sì come sono di diversi luoghi, così hanno diversi modi e costumi di vivere. Quelli che abitano fra Numidia e Libia vivono vita misera e piena di molta povertà, né sono in ciò differenti dai sopra detti popoli africani abitanti in Libia, ma sono per altro di più animo. Fanno mercanzie de' lor camelli nella terra de' negri, e tengono cavalli in gran numero: e questi sono quelli che nella Europa si dicono cavalli barberi. Di continuo si danno alle caccie, sì come di cervi, d'asini selvatichi, di struzzi e d'altri animali. Né è da tacer che la maggior parte degli Arabi di Numidia sono versificatori e compongono lunghi canti, descrivendo in quelli le lor guerre e caccie e anche cose d'amor, con grande eleganzia e dolcezza, e i lor versi sono fatti con rime nel modo de' versi vulgari d'Italia. Sono uomini liberali, ma non hanno facultà di poter mantener riputazione e usar cortesia, percioché in quei diserti sono carichi d'ogni disagio. Costoro vestono secondo il costume dei Numidi, fuori che le lor donne hanno qualche differenza nel vestire delle donne dei detti Numidi. I diserti ove abitano questi Arabi erano prima tenuti da popoli africani; ma quando la loro generazione entrò nell'Africa, allora con guerra scacciò di là i Numidi, ed ella si rimase ad abitar ne' deserti vicini ai paesi dei datteri, e i Numidi andarono a far le loro abitazioni ne' diserti che sono propinqui alla terra negra. 
Gli Arabi che abitano dentro di Africa, cioè fra il monte Atlante e 'l mar Mediterraneo, sono più agiati e più ricchi degli altri, massimamente cerca il vestire e cerca ai fornimenti dei loro cavalli e alla bellezza e grandezza dei padiglioni. Hanno ancora cavalli molto più belli, ma non sono così veloci nel corso come quei del diserto. Questi Arabi fanno lavorare i loro terreni e vi cavano grandissima copia di grano. Hanno di pecore e di buoi un numero quasi infinito, e per questa cagione non si possono fermare in un luogo solo, percioché un terreno non basta a pascer tante bestie. Sono eziandio più barberi quasi e vili di natura di quei del diserto, ma sono nondimeno liberali, e una parte di loro, la quale abita nel regno di Fez, è soggetta e tributaria del re.

Quegli che abitano d'intorno al regno di Marocco e in Duccala un tempo vissero liberi da ogni gravezza, insino a tanto che i Portogalesi ebbero dominio di Azafi e di Azemor: allora tra loro si sollevarono parti e domestiche discordie, per le quali il re di Fez una parte ne roinò e un'altra il re di Portogallo, senza che la carestia, che in questi anni fu in Africa, gli oppresse in modo che i miseri Arabi volontariamente andarono in Portogallo, offerendosi per ischiavi a chiunque desse loro nutrimento. Così di essi niuno in Duccala rimase.

Ma gli Arabi i quali abitano nei diserti vicini al regno di Telensin e ne' diserti vicini a Tunis, tutti vivono nel modo che vivono i loro signori, percioché ciascun principe ha molto buone e larghe provisioni dai re, e queste distribuisce e va compartendo fra il suo popolo, per vietar le discordie e tenerlo in pace e in amica unione. Costoro hanno vaghezza di andar bene in ordine e tenere i cavalli molto ben guarniti, e i lor padiglioni sono belli e grandi. Sogliono il tempo della state andare a' confini di Tunis a pigliar le provisioni loro, e l'ottobre si forniscono di ciò che fa lor bisogno, sì come di vettovaglie, di panni e d'arme, e con queste ritornando nei diserti vi rimangono tutto il verno. Poscia la primavera si sollazzano nelle caccie, con cani e falconi seguitando ogni sorte di fiere e di uccelli. E io molte volte ho alloggiato con loro e mi sono valuto di molte cose, e hogli veduti nei lor padiglioni più forniti di panni, di rami, di ferri e di ottoni che non sono molti nelle cittadi. Tuttavia non è da fidarsi di questi tali, percioché rubbano e assassinano volentieri; e pur sono assai cortesi: amano la poesia e nella lor lingua commune dettano versi elegantissimi, ancora che il linguaggio oggi sia corrotto, e un poeta di qualche nome è molto grato ai signori e dannogli di gran premi, né vi potrei dire quanta purità e grazia essi abbiano nei lor versi. 
Le donne di costoro vanno secondo il paese molto ben vestite. Gli abiti sono camicie negre con larghe maniche, sopra le quali portano un lenzuolo del medesimo colore o pure azurro, e se lo involgono e aggroppano di maniera che, venendone gli orli su le spalle, di qua e di là è ritenuto da certe fibbie d'argento fatte assai maestrevolmente. Usano di aver nell'orecchie molti anelli pur d'argento, e così nelle dita delle mani, e similmente con alcuni cerchietti si cingono le gambe e le calcagna, come è costume degli Africani. Portano ancora queste donne certi pannicini su la faccia, i quali sono forati dirimpetto agli occhi, e quando essi veggono un uomo che non sia loro parente, con que' pannicini ascondono subito il viso e non parlano, ma quando sono fra mariti e parenti tengono sempre il drappicino alzato. E come gli Arabi si vanno mutando di luoco in luoco, così pongono le lor donne a seder sopra li camelli su certe selle per ciò fatte a modo di ceste, ma coperte con bellissimi tapeti, e sono tanto piccole che non vi può capere altro che una femina sola. E i giorni che sono eletti per combattere menano similmente seco le donne per confortarle e far che men temano. Sogliono ancora queste donne, avanti che elle vadano a marito, dipingersi la faccia, il petto e tutte le braccia insieme con la mano e le dita, percioché ciò tengono per cosa molto gentile. Questa cotale usanza hanno presa dagli Arabi africani, nel tempo che essi vennero ad abitar tra loro, che prima non l'avevano. Ma tra cittadini e nobili della Barberia non si costuma ciò fare, anzi le lor donne si mantengono nella medesima bianchezza con la quale nacquero. È vero che alle volte prendono certe tinte fatte col fumo di galla e di zaffrano, e con quelle tingendosi la metà della guancia formanvi una cosa tonda come uno scudo, e fra le ciglia fanno quasi uno triangolo, e sul mento non so che assomiglia a una foglia d'oliva, e alcune ancora tingono tutte le ciglia. E percioché questa foggia è lodata dai poeti arabi e dalle persone nobili, la tengono per leggiadra e per gentile. Ma non portano questi loro abbellettamenti più che due o tre giorni, percioché tutto lo spazio che gli hanno non possono comparer dinanzi ai loro parenti, eccetto al marito e a' figliuoli, conciosiaché esse ciò fanno per incitar la lussuria, parendo a quelle di accrescere in cotal modo molto fieramente le loro bellezze.

Gli Arabi che abitano ne' diserti che sono fra Barberia ed Egitto. 
La vita di questi è piena di miseria, percioché i paesi nei quali abitano sono sterili e asperi. Tengono pecore e camelli, ma per la piccola quantità dell'erba poco fruttano. E per quanto si estende la lunghezza di quelle campagne non c'è luogo alcuno da potervi seminar niuna sorte di grano, eccetto che si truovano in quei diserti certe terricciuole a modo di casali, nelle quali vi sono alcuni piccoli poderetti di datteri, e vi si semina pure qualche poca parte di grano, ma è sì poca che non potrebbe esser meno. Il che è cagione che gli abitanti di questi casali ricevino da loro continovi impacci e travagli. E se bene alle volte costumano di dar loro camelli e pecore all'incontro di datteri e di grani, nondimeno ciò, per la poca quantità, a tanta moltitudine non basta. Per la qual cosa aviene che ad ogni tempo si truovano molti figliuoli dei detti Arabi appresso i Siciliani, lasciati loro per pegno e securtà di grano che i poveri uomini pigliano in credenza. E se fra certo termine convenuto nei mercati non pagano la somma dei danari che sono debiti, i creditori tengono $\mathrm{i}$ figliuoli per ischiavi, e volendogli i padri riscuotere converrebbe accattar tre volte maggior quantità del debito, di modo che sono costretti a lasciarvegli. Dal che procede che questi Arabi sono i peggiori e i più terribili assassini che siano nel mondo, e quanti forestieri vengono nelle mani loro, poi che gli hanno spogliati di ciò che lor trovano, gli vendono ai Siciliani. A tanto che da cent'anni in qua non è passata carovana nessuna per la rivera del mare che cinge il detto diserto nel quale è l'abitazione di questi Arabi, ma quando ve ne passa alcuna, ella suole andar per la terra ferma, discosto dal mare cerca cinquecento miglia.

Io fuggendo dalle loro mani corsi tutta quella rivera per mare con tre legni di mercatanti, e come questi ne viddero vennero correndo al porto, mostrando di voler con noi fare alcuni mercati che ci sarebbono a utile. Ma non ci fidando di loro, niuno volle smontar nel terreno prima che essi per sicurtà alcuni lor figliuoli diedero in poter nostro. Il che fatto, comprammo alquanti di lor castrati e botiro e si partimmo di subito, temendo per ogni poco di esser sovragiunti da corsali di Sicilia e di Rhodo. Costoro infine sono brutti, mal vestiti, asciutti e macilenti per la gran fame, e tali che pare che la maladizione d'Iddio sia ad ogni tempo stata data sopra questa dannata e pessima generazione, senza da quella partirsi mai. 
Sono molti lignaggi d'Africani i quali tengono esercizio di levar pecore e buoi, né in altro si travagliano tutto dì. E la maggior parte di essi abitano a piè del monte Atlante, e ancora fra il detto monte. Questi, dovunque si trovino, sono sempre tributari o dei re o degli Arabi; tolgo fuori quelli che abitano in Temesna, i quali sono liberi e hanno gran potere. Parlano nella lingua africana, e alcuni tengono l'araba per la vicinanza e conversazione che essi hanno di continuo con gli Arabi che abitano in le campagne di Urbs, in li confini di Tunis.

V'è un altro popolo, che abita dove confina Tunis con i paesi dei datteri, il qual popolo molte volte ebbe ardimento di far guerra al re, come avenne negli anni poco adietro, ne' quai il figliuolo del detto re, partitosi da Costantina per riscuotere i tributi dal detto popolo, fu dal principe di quello assalito, il quale gli s'era fatto incontro con duemila cavalli, e combattendo ruppe la gente del figliuolo del re e ucciselo, togliendone i carriaggi: e ciò che v'era l'anno di legira 915. Doppo questa rotta il medesimo popolo cominciò a essere in buon nome e in molta riputazione appresso tutti. E molti di quegli Arabi che erano al servigio del re di Tunis, fuggendo da luoghi al re sottoposti, se ne vennero ad abitar coi vincitori, in modo che il principe è divenuto un de' maggiori e de' più famosi signori che abbia tutta l'Africa.

\section{Fede degli antichi Africani.}

Gli Africani negli antichi tempi furono quasi idolatri, come sono i Persi, i quali adorano il fuoco e il sole, e tenevano belli e ornati tempi ad onore dell'uno e l'altro, e in quei di continovo ardeva il fuoco, dì e notte guardato che non si spegnesse, nella guisa che nel tempio della dea Veste si soleva osservare appresso i Romani. Il che nelle croniche degli Africani e dei Persi diffusamente si contiene. È vero che gli Africani di Numidia e di Libia adoravano i pianeti e a quelli sacrificavano; e alcuni degli Africani negri ebbero in venerazion Guighimo, che nella lor lingua significa il Signor del cielo: e questa buona mente ebbero senza essere informati né da profeta né da dottore alcuno. E d'indi a certo tempo furono introdotti nella legge giudaica, nella quale vi stettero molti anni, in fin tanto che alcuni regni de negri si fecero cristiani, e tanto rimasero nella fede di 
Cristo che si sollevò la setta di Maumetto, 268 di legira. Allora, andati a predicare in quelle parti alcuni discepoli di Maumetto, con le loro persuasioni tirarono gli animi degli Africani a quella legge, di maniera che tutti i regni dei negri che confinano con Libia diventarono maumettani. Pure oggidì v'è qualche regno nel quale ci sono rimasi fin ora, e rimangono, cristiani: solo quelli che erano giudei e da cristiani e da Africani furono totalmente distrutti. Quegli altri che abitano vicino al mare Oceano sono tutti gentili e adorano gli idoli, e questi hanno veduti, e ancora avuta qualche pratica con loro, molti Portogallesi.

Gli abitanti di Barberia rimasero essi ancora lungo tempo idolatri, e dugentocinquanta anni avanti il nascimento di Maumetto diventarono cristiani, percioché quella parte dove è Tunis e Tripoli fu dominata da certi signori pugliesi e siciliani, e la rivera di Cesaria e di Mauritania similmente fu signoreggiata da Gotti. In que' tempi eziandio molti signori cristiani, fuggendo dal furor di questi Gotti e lasciando adietro le natie e dolci contrade d'Italia, vennero ad abitar vicini a' terreni di Cartagine, dove poscia vi fecero dominio. Ma è da saper che questi cristiani di Barberia non tenevano l'osservanza e l'ordine della Chiesa romana, ma s'aderivano alle regole e alla fede degli arriani, e di quelli fu santo Agostino. Gli Arabi adunque, quando essi vennero per acquistar la Barberia, trovarono i cristiani già padroni e signori di quelle regioni, per che fecero insieme di molte battaglie. In fine piacque a Iddio di dare agli Arabi la vittoria, onde gli arriani si fuggirono, e chi andò in Italia e chi in Ispagna. Ma, doppo la morte di Maumetto cerca dugento anni, quasi tutta la Barberia divenne maumettana. Egli è vero che molte fiate queste genti ribellarono, e negando la fede di Maumetto amazzarono i lor sacerdoti e governatori; ma i pontefici, ogni volta che ciò udirono, subito mandarono eserciti contro ai detti Barberi. E questo intravenne fin che giunsero in Barberia gli scismatici, cioè quelli che fuggirono dalli pontefici di Bagaded: allora la fede di Maumetto fermò il piede. Tuttavia sempre furono e sono ancora rimase tra lor medesimi molte eresie e differenzie. Ma della legge di Maumetto, cioè delle cose di più importanza, e della diversità che è fra gli Africani e quegli di Asia, col favor d'Iddio io penso trattarne pienamente in un'altra opera: in tanto forniremo questa. 
Gli istorici arabi hanno per ferma oppenione che gli Africani non tenessero altra sorte di lettera che la latina, e dicono che quando gli Arabi acquistarono l'Africa, massimamente la Barberia, dove fu ed è la civiltà di Africa, essi altra lettera non vi trovarono che la latina. Confessano bene che gli Africani hanno una lingua differente e propria loro, ma che essi usano communemente le lettere latine, sì come fanno nell'Europa i Tedeschi. E quante istorie tengono gli Arabi degli Africani, tutte sono tradotte della lingua latina, opere antiche, e alcune scritte nel tempo degli arriani e alcune avanti. E gli autori di quelle sono nominati, ma i lor nomi mi sono usciti di mente. E penso che queste tali opere siano molto lunghe, percioché gli interpreti loro sogliono dire: "La tal cosa si contiene a settanta libri". Vero è che gli Arabi non tradussero le dette opere secondo gli ordini degli autori, ma pigliarono la somma dal nome dei signori, e di qui disposero e compartirono i tempi per li detti signori e principi, accordandogli con i tempi dei re di Persia o di quei degli Assiri o dei Caldei o dei re d'Israel. E ne' tempi che i scismatici regnarono nell'Africa, cioè quegli che fuggirono dai pontefici di Bagaded, essi comandarono che si devessero abbruciar tutti i libri delle istorie e delle scienze degli Africani, percioché pareva loro che i detti fossero cagione che gli Africani rimanessero nell'antica superbia, e che facessero ribellar e renegar la fede de Maumetto.

Alcuni altri nostri istorici dicono che gli Africani avevano proprie lettere, ma dapoi che i Romani dominarono la Barberia, e d'indi a molti tempi ne furono signori i cristiani che fuggirono della Italia e i Gotti, allora essi perderono le lettere loro. Percioché fa di mestiero ai soggetti seguitar le usanze dei padroni, se essi vogliono piacere a quelli: come sotto al dominio degli Arabi è avenuto ai Persi, i quali similmente hanno perdute le loro lettere, e tutti i loro libri furono abbruciati pur per comandamento dei pontefici macomettani, percioché estimavano che i Persi, mentre avevano i libri che conteneano le scienze naturali e le leggi e la fede degl'idoli, non potessero esser buoni e catolici maumettani. Abbruciate adunque l'opere, proibirono lor le scienzie, e il somigliante fecero i Romani e i Gotti quando, come s'è detto, signoreggiarono la Barberia. E parmi che per testimonio di ciò possa bastare che in tutta la Barberia, così per le città di mare come della campagna, cioè di quelle che sono anticamente edificate, quanti epitafi si veggono sopra le sepolture o nei muri di qualunque edificio, tutti sono in latine lettere e niuno altramente. Né io per tutto ciò crederei che gli Africani quelle tenessero per proprie lettere né che in quelle avessero scritto, percioché non è da dubitar che quando i Romani, che fur loro nimici, dominarono quei luoghi, essi, come è costume de' vincitori 
e per maggior lor disprezzo, levassero tutti i lor titoli e le lor lettere e vi mettessero i loro, per levar insieme con la dignità degli Africani ogni memoria e sola vi rimanesse quella del popolo romano. Sì come volevano eziandio degli edifici de' Romani fare i Gotti, o come volsero far gli Arabi di quelli dei Persi, e come alla giornata sogliono fare i Turchi ne' luoghi che prendono di cristiani, guastando non solamente le belle memorie e gli onorati titoli, ma nelle chiese le imagini de santi e sante che vi truovano. O non si vede egli in Roma medesima a' nostri tempi che alcuna volta, in principio d'un bello e degno edificio da un signore con grandissima spesa incominciato e per morte lasciato imperfetto, il successore o farà disfar per fino alle fondamenta per fare egli nuova fabrica, o, posto che quello fosse fornito o che lo lasci in piè, per ogni poco di novità che vi aggiunge vuole che siano levate le arme di quel signore e che vi si pongano le sue? O pure, se è tanto da bene che ve le lasci, le sue sono messe di sopra, e con lunghi epitafi fatti a misura e a compassi tengono il più onorato luoco.

Non è adunque da maravigliarsi che la lettera africana sia perduta. E da 900 anni in qua gli Africani usano la lettera araba, e Ibnu Rachich scrittor africano nella sua cronica fa di questa materia una lunga disputa, cioè se gli Africani avevano proprie lettere o no, e conclude che essi l'avevano, dicendo che chi nega ciò può medesimamente negar che gli Africani abbiano avuta lingua propria. Aggiungeva ancora che è impossibile che un popolo che abbia una lingua particolare usi nello scrivere una lettera strana.

\section{Sito di Africa.}

L'Africa, sì com'è divisa in quattro parti, così esse parti sono nei siti differenti. La riviera del mare Mediterraneo, cioè dallo stretto di Zibeltara per insino a' confini di Egitto, tutta è occupata da monti, e si allargano verso mezzogiorno cerca miglia cento, e in alcuni luoghi più e in alcuni altri meno. Da questi monti insino al monte Atlante v'hanno pianure e alcuni piccoli colli, e per tutti i monti della detta rivera si trovano molti fonti, i quali poscia si convertono in certi fiumicelli, chiari e all'occhio vaghi e dilettevoli molto. Dapoi delle quai pianure e colli è il monte Atlante, che incomincia dal mare Oceano, cioè dalla parte di ponente, e si estende verso levante fino a' confini di Egitto. Doppo Atlante si scuovrono le pianure dove è Numidia, nelle quali nascono i 
datteri, ch'è un paese quasi tutto arena. Doppo Numidia sono i diserti di Libia, pur tutti arenosi insino alla terra negra: nondimeno per li detti diserti si truovano molti monti, ma i mercatanti per quelli non fanno il loro cammino, percioché fra i monti vi sono molti passi larghi e piani. Doppo i diserti di Libia è la terra negra, le maggior parti della quale sono piane e arenose, fuor che le coste del fiume Niger e tutti quei luoghi dove bagnano e arrivano l'acque sue.

\section{Luoghi fieri e nivosi di Africa.}

Tutta la riviera di Barberia e i monti nella riviera contenuti partecipano quasi del freddo più tosto che altramente, e a qualche stagione dell'anno vi nevica. Per tutti i detti monti nascono grani e frutti, ma frumento non molto in copia, e gli abitanti la più parte dell'anno mangiano pane di orgio. I fonti che si trovano per li detti monti hanno certe acque che tengono il sapore del terreno e sono quasi torbide, e massimamente nelle parti che confinano con Mauritania. Sono eziandio sopra i detti monti molti boschi di alberi altissimi, e le più volte pieni d'animali, quai buoni e quai cattivi. Ma i piccoli colli e le pianure che sono fra i detti monti e il monte Atlante sono tutti buonissimi terreni, che producono gran quantità di grani e d'ottimi frutti; e per tutti i detti colli e pianure passano tutti i fiumi che nascono di Atlante e vanno al mare Mediterraneo. Ma in questa parte si truovano pochi boschi, e migliori sono le pianure che v'hanno fra l'Atlante e l'Oceano, come è la regione di Marocco, la provincia di Duccala, e tutta Tedle e Temesne insieme con Azgar insino allo stretto di Zibeltara.

Il monte Atlante è molto frigido e sterile: in esso nascono pochi grani, e per ogni sua parte sono folti e oscuri boschi, e da lui ne nascono quasi tutti i fiumi di Africa. I fonti che si truovano nel detto monte nel mezzo della state sono freddissimi, di maniera che uno che tenesse la mano in quell'acqua per ogni piccolo spazio, senza dubbio ve la perderebbe. Le parti del detto monte non sono tutte ugualmente fredde, percioché v'hanno alcuni luoghi quasi temperati ne' quali vi si può assai bene abitare, e sono eziandio abitati, come vi si dirà partitamente nella seconda parte del nostro libro. Le parti disabitate o sono molto fredde o molto aspere: quelle che rispondono verso Temesna sono le aspere; le fredde riguardano verso Mauritania. Tuttavia quegli che attendono alle pecore vi vanno nel tempo della state a pascervi le loro bestie. Ma il 
verno non è possibile potervisi fermare per modo niuno, percioché sempre che la neve è venuta giù, subito si muove un vento dalla parte di tramontana, così dannoso ch'egli occide tutti gli animali che si truovano in quei luoghi, e molti uomini ancora vi muoiono, percioché quivi è il passo fra Mauritania e Numidia. E avendo in costume i mercatanti dei datteri partirsi di Numidia carichi di datteri nel fine di ottobre, alle volte la neve ve gli coglie di maniera che niuno ve ne resta vivo, conciosiaché, cominciando la notte a nevicare, la mattina si truova la carovana sepolta e affogata nella neve: né solamente la carovana, ma tutti gli alberi sono coperti, di modo che non si può vedere orma né segno dove siano i corpi morti. E io due fiate per gran miracolo sono scampato dal pericolo di questa morte nel tempo che io facevo questi cammini, delle quali non vi dispiacerà intender come una me ne avenisse.

Partiti insieme molti mercatanti da Fez, si trovammo con la carovana del sovradetto mese nell'Atlante. E cominciando cerca all'occaso del sole una fredda e folta neve, si ridussero insieme certi Arabi, i quali erano da dieci in dodici cavalli, e m'invitarono lasciando la carovana a girmene a buono albergo con esso loro. Io, non potendo ricusar lo invito e temendo di qualche inganno, feci pensiero di levarmi da dosso certa buona quantità di danari che mi trovava avere; e perché già questi tali incominciavano a cavalcare, affrettandomi essi, fingendo che '1 bisogno naturale m'astringesse n'andai in disparte sotto un albero, e quivi tra sassi e terreno come il meglio potei nascosi e riposi i danari, segnando con diligenza l'albero. Cavalcammo adunque taciti presso alla mezzanotte; allora un di costoro, parendo loro esser tempo di far quello che avevano in animo, cioè di tormi i danari e lasciarmi alla buona ventura, mi domandò se io alcun danaro aveva addosso. Io risposi che i miei danari aveva lasciato nella carovana a un mio caro e stretto parente. Non fui creduto, e per saperne essi il vero volsero che in quel gran freddo mi spogliassi per insino alla camicia, e nulla non vi trovando cominciarono meco a ridere, dicendo che ciò avevano fatto per ischerzo e per conoscer se io era uomo forte e s'io sapeva sopportare il freddo. Ora, seguendo il cammino sempre al buio e per gl'incommodi sì del tempo come della notte, quando piacque a Dio sentimmo il belar di molte pecore, verso il quale ci inviammo drizzando i cavalli tra boschi e alte rupi, di maniera che ci soprastava un altro pericolo. Infine in certe grotte alte trovammo alcuni pastori, i quali a gran fatica v'avevano condotte dentro le lor pecore e, acceso un buon fuoco, vi stavano al dintorno. I quali come noi viddero e conobbero questi essere Arabi, prima ebbero paura non qualche dispiacer gli facessero, 
dapoi s'assicurarono sopra la qualità del tempo e ne dimostrarono assai cortese accetto, e dieronci mangiar di ciò che avevano, cioè pane, carne e cacio. Fornita la cena, ci ponemmo a dormire a canto il fuoco, tutti tremando di freddo, e più io che poco dianzi era stato spogliato ignudo, senza la paura che io aveva. Con questi pastori dimorammo due dì e due notti, che tanto continovò il nevicare. Il terzo dì fu cessato, onde i pastori incominciarono con gran diligenzia a levar via la neve, che aveva tutta rinchiusa e turata la bocca della grotta. Il che fatto ne menarono dove avevano allogati i nostri cavalli, che fu in certe altre grotte, e provedutogli di molto fieno; i quali trovando in buono essere su vi salimmo per dispartirci. Quel giorno si mostrò il sole chiaro e levò quasi tutta la freddezza dei dì trascorsi. I pastori vennero alquante miglia con noi, dimostrandoci alcune piccole vie dove sapevano che non poteva esser molto alta la neve: ma con tutto ciò i cavalli v'andavano sotto insino al petto. Giunti che fummo ne' confini di Fez in una villa, ci fu data certezza che la carovana era stata affogata dalla neve. Allora gli Arabi, perduta la speranza d'esser pagati delle loro fatiche, percioché avevano accompagnata la carovana e assecuratala, pigliarono un giudeo che era nella nostra compagnia, il quale aveva nella carovana cinquanta some di datteri, e il menarono prigione nei lor padiglioni con animo di tenervelo per insino a tanto che egli pagasse per tutti. A me levarono il cavallo e mi accomandarono a Dio. Io, preso a vettura un mulo fornito con certe bardelle che usano coloro tra quei monti, il terzo dì giunsi a Fez, dove trovai che già era stata recata la trista novella, e io similmente da' miei era stato riputato morto come gli altri. Ma ciò per sua bontà non era piaciuto a Dio.

Ora, lasciando di raccontar le mie sventure, ritornerò al lasciato ordine. Di là dal monte Atlante sono paesi secchi e caldi, dove si trovano pochi fiumi, i quali nascono pure in Atlante e corrono verso il diserto di Libia spargendosi nell'arena, e alcun di loro forma qualche lago. Nei detti paesi vi sono pochi terreni buoni alla semenza, ma infinite piante di datteri; si trova ancora qualche altro albero fruttifero, ma questi sono rari. E ne' luoghi di Numidia che confinano con Libia sono certi monti aspri, ma senza albero niuno, ne' piedi de' quali ci sono molti luochi di certi alberi tutti spinosi, i quali non fanno frutto. Né fonti vi sono né fiumi, se non alcuni pozzi quasi incogniti alle genti, tutti fra quei colli e monti diserti. In tutti i terreni di Numidia sono molti scorpioni e serpi, dai morsi e punture de' quali nella state ogni anno vi muore di gran gente. Libia è eziandio paese disertissimo, secco e tutto arena, dove non si trova né fonte né fiume né acqua, eccetto pure certi pozzi i quali hanno acqua più tosto salsa che no, e questi non 
sono molti. E v'hanno alcuni luoghi ne' quali per sei e sette giorni di cammino non si trova acqua, e bisogna che i mercatanti se la portino negli utri sopra i camelli, massimamente nella strada che è da Fez a Tombutto o da Telensin ad Agadez.

E assai peggio è il viaggio che s'è trovato da moderni, il quale è di andar da Fez fino al Cairo per lo diserto di Libia. Nondimeno in questo viaggio si passa a canto d'un grandissimo lago, d'intorno al quale sono i popoli di Sin e di Gorrhan. Ma nel viaggio di Fez a Tombutto si trovano alcuni pozzi foderati dentro o dei cuori dei camelli o murati con le ossa de' detti animali, ed è gran pericolo a' mercatanti, quando si mettono a quel viaggio d'altro tempo che il verno, percioché allora soffiano alcuni silocchi o venti meridionali, e levano tanta arena che cuopre i detti pozzi, in tanto che i mercatanti, che si partono con speranza di trovar ne' luoghi consueti l'acqua, non vi discernendo né segno né vestigio di pozzo per esser coperti dalla arena, sono costretti a morirsi di sete, e sovente da viandanti si veggono l'ossa loro e di loro camelli biancheggiare in diversi luoghi. A questo c'è un solo rimedio e molto strano, il quale è che amazzano alcun camello, e spremendo dalle loro budella l'acqua che vi trovano, se la beono e compartono per insino che s'abbattino a qualche pozzo o che per la lunga sete muoiono. E trovansi nel diserto di Azaoad due sepolture fatte di non so che sasso, nel quale sono intagliate alcune lettere che dicono ivi esser sepelliti due uomini, uno de' quali fu ricchissimo mercatante, e passando per quel diserto infestato dalla sete comperò dall'altro, che era vetturale, una tazza di acqua per diecimila ducati: ma tuttavia morì dalla sete e il mercatante che comperò l'acqua e il vetturale che gliela vendé.

Sono nel detto diserto molti nocivi animali e degli altri ancora che non sono nocivi: ma di questi io sono per dirvi nella quarta parte del libro dove io tratterò di Libia, o vero dove io farò particolar menzione degli animali che si trovano in Africa. Penso ancora di raccontare altrove i pericoli che avenuti mi sono per li viaggi ch'io ho fatto in Libia, massimamente in quello di Gualata, di maniera che non poca maraviglia vi resterà nell'animo, conciosiaché alle volte abbiamo perduta la strada di trovar l'acqua percioché la guida si smarriva; e oltre abbiamo trovati i pozzi turati d'arena; e quando i nimici tenevano i passi dell'acqua, fu di necessità di risparmiar la poca che ci trovammo il meglio che per noi si poté, compartendo quella parte, che devea darci il bere a fatica per cinque giorni, per altretanti. Ma se io qui volessi distendere le particolarità di un solo viaggio, non bisognerebbe che io scrivessi di altro. 
Nella terra negra sono i paesi caldissimi, e participano anco dell'umido per cagione del fiume Niger. E tutte le regioni che sono vicine al detto fiume hanno buonissimi terreni, dove vi nasce grandissima quantità di grani e trovavisi infinito numero di bestie; ma non v'ha frutto di niuna sorte, eccetto alcuni frutti che producono alberi molto grandi, i quali si assomigliano alle castagne ma tengono alquanto dell'amaro. Questi arbori si discostano dal fiume verso la terra ferma; il frutto ch'io dico è chiamato nella lor lingua goro. Egli è vero che qui nascono in quantità cocuccie, citrioli, cipolle e altri frutti. Né in tutta la riviera del Niger né ancora ne' confini di Libia si trovano monti o colle alcuno, ma ben molti laghi formati dall'inondazion del Niger; e intorno quelli sono molti boschi, ne' quali v'abitano elefanti e altri animali, come eziandio particolarmente a suoi luoghi vi si dirà.

\section{Moti naturali dell'aere in Africa, e diversità che da quelli procedono.}

In tutta quasi la Barberia, passata nella metà dello ottobre, incominciano le pioggie e il freddo; nel decembre eziandio e nel gennaio il freddo è maggiore, come negli altri luochi, ma quivi solamente nella mattina, di maniera che a niuno fa bisogno di scaldarsi al fuoco. Nel febraio ordinariamente v'ha quasi men freddo, ma sovente in un giorno il tempo farà cinque e sei volte mutazione. Nel marzo soffiano impetuosissimi venti di ponente e di tramontana, e questi ingravidano il terreno e fanno fiorire gli alberi; e nell'aprile quasi tutti i frutti cominciano a prender forma, intanto che ne' piani di Mauritania a' principii di maggio ed eziandio al fine di aprile si mangiano ciriegie. E come sono passate tre settimane di maggio, si colgono i fichi maturi come la state, e nella terza settimana di giugno incomincia a maturarsi l'uva e vi si mangia ancora. Le mele, le pere, armellini, grisomeli e i pruni divengono maturi fra il luglio. I fichi dell'autunno son maturi nello agosto, e così le giuggiole; ma nel settembre è il colmo e dei fichi e delle persiche. Passato mezzo agosto incominciano a seccar l'uva, e la seccano al sole; e se piove nel settembre, di tutta l'uva che è rimasa fanno vini e mosti cotti, massimamente nella provincia di Rif, come pure particolarmente vi si dirà. Nel mezzo d'ottobre colgono le mele, le granate e i cotogni; nel novembre l'olive: ma non si colgono con le scale, come si fa nella Europa, spiccandole con le mani, percioché non si 
può fare scale tanto lunghe che arrivino all'altezza degli alberi, conciosiacosaché là gli olivari sono grossissimi e altissimi, massimamente quegli di Mauritania, di Cesaria; ma quelli che sono nel regno di Tunis tengono somiglianza con gli altri che nascono nella Europa. Quando adunque gli uomini vogliono coglier le olive, vanno sugli alberi con bastoni lunghissimi in mano, e percotendo i rami le fanno giù cadere. Il che conoscono esser lor danno, percioché ciò faccendo danno sopra gli occhi dei ramoscelli giovanetti e molti ne guastano. Aviene ancora che le olive di Africa tale anno vi sono in abondanza e alcun altro non vi se ne trova acino. E v'hanno certe olive grosse che non sono buone da fare oglio, ma si mangiano concie, eziandio in tutte le stagioni.

\section{9}

\section{Termini e qualità dell'anno.}

Sempre i tre mesi della primavera sono quasi temperati. Entra la primavera a' quindici di febraio e compie a' diciotto di maggio: e in tutta questa stagione è quasi di continovo il tempo bello, ma se non piove da' venticinque d'aprile insino a' cinque di maggio l'aricolta dell'anno è pessima, e chiamano l'acqua che apportano quelle pioggie acqua di Naisan. La quale essi tengono per benedetta aqua d'Iddio, e molti se la serbano in vaselli e ampolle, tenendosela in casa per divozione. La state pur dura per insino a' sedici di agosto, e tutto questo tempo è calidissimo, spezialmente il giugno e il luglio, e per tutti questi cotai tempi è sereno e bell'aere, eccetto che alcuni anni se piove o di luglio o di agosto. Da quelle acque procede malvagità di aere, e molti s'infermano d'una acuta e continova febbre, e pochi sono quelli che scampino. La stagione dell'autunno appo loro incomincia a' diciasette di agosto e segue fino a' sedici di novembre, e questi due mesi, cioè agosto e settembre, sono di minor calore; ma pur tuttavia que' dì che si framettono ne' quindici di agosto per insino a' quindici di settembre sono dagli antichi chiamati il forno del tempo, percioché agosto fa maturare i fichi, le melagrane e i cotogni, e secca l'uva. Da' quindici di novembre incomincia la stagione del verno e si estende fino a' quattordici di febraio, e nel suo principio s'incomincia a seminare $\mathrm{i}$ terreni del piano; ne' monti s'incomincia l'ottobre. Gli Africani hanno oppenione che nell'anno sono quaranta dì caldissimi, i quali sogliono principiar da' dodici di giugno; così all'incontro tengono che ce ne siano altretanti freddissimi, che cominciano a' dodici di decembre. E gli equinozii similmente tengono, e così sono, ne' sedici di marzo e ne' 
sedici di settembre; tengono eziandio che 'l sole ritorni ne' sedici di giugno e ne' sedici di decembre. Così questa tal regola è appresso loro, e la serbano sì nell'affitar dei loro poderi e sì nel seminare e raccorre, come nel navicare e nel trovar le stanze e le revoluzion dei pianeti. Ma molte cose pertinenti a ciò e più utili fanno insegnar con diligenza nelle scole a' fanciulli.

Ci sono ancora molti contadini, e arabi e altri, che senza avere imparato mai lettera alcuna sanno parlar delle cose della astrologia molto copiosamente, adducendo di ciò che dicono ragioni evidentissime. Le regole e la cognizione che essi hanno sono cavate dalla lingua latina e portate nella arabica, e appellano i mesi per gli stessi nomi che gli appellano i Latini. Hanno similmente un gran volume in tre libri diviso, il quale essi chiamano nella lingua loro il Tesoro degli agricoltori, ed è tradotto dalla lingua latina all'arabica in Cordova nel tempo di Mansor, signore di Granata. Il qual libro tratta di tutte le cose che fanno di bisogno alla agricoltura, cioè del tempo e del modo del seminar, del piantare, d'incalmar gli alberi e di contrafare ogni frutto o grano o legume. E maravigliomi molto che appresso gli Africani siano molti libri tradotti dalla lingua latina, i quali oggi non si trovano appresso i Latini. I conti e le regole che tengono gli Africani, e ancora tutti i maumettani, per le cose pertinenti alla fede e alla legge loro tutti sono secondo la luna. E hanno l'anno loro di trecentocinquantaquattro giorni, percioché sei mesi fanno di trenta dì e altri sei di ventinove, il che posto insieme aggiugne alla detta somma. Le feste e i digiuni loro vengono in diversi tempi. L'anno adunque arabo e africano è meno del latino undici giorni, e quelli undici giorni fanno tornar l'anno nostro adrieto.

È da sapere ancora che nelle parti ultime dell'autunno e tutto il verno, ed eziandio alcuna parte della primavera, sono tempi tempestosi e orridi di grandini, di folgori e di saette, e molti luoghi sono in Barberia ne' quali nevica. In quella tre venti che soffiano da levante, da silocco e da mezzogiorno sono molto nocevoli, massimamente il maggio o il giugno, percioché guastano tutti i grani e non lasciano crescere né divenir maturi i frutti. Ancora ai grani fa gran danno la nebbia, e quella più che si mostra quando fiorisce il grano, percioché alle volte ella dura tutto il dì. Nel monte Atlante l'anno non è più che due stagioni, percioché d'ottobre insino ad aprile tutti i sei mesi sono verno, e d'aprile fino a settembre tutto è state; ma per tutto l'anno in tutte le sommità del detto monte si trova di continovo neve. In Numidia le stagioni corrono quasi con maggiore velocità, percioché il maggio si colgono i grani e i datteri nell'ottobre; e la metà di 
settembre con tutto ottobre fino a gennaio è la più fredda parte di tutto l'anno. Se piove il settembre, i datteri quasi per la maggior parte si guastano e fassene trista raccolta. Tutti i terreni di Numidia vogliono essere adacquati per la sementa, onde, se aviene che non piova in Atlante, tutti i fiumi di Numidia rimangono quasi secchi, di maniera che non possono adacquare i terreni, e non piovendo similmente l'ottobre non bisogna aver speranza di seminar quell'anno; così, mancando l'acqua il mese d'aprile, non si può coglier grano nelle campagne. Ma quando non piove è buona raccolta di datteri, e quegli di Numidia stimano molto più la raccolta dei datteri che del grano, percioché, ancora che egli fosse grandissima abondanza di grano, non perciò sarebbe a sufficienza per la metà dell'anno; ma quando la raccolta dei datteri è buona allora non mancano grani, percioché gli Arabi e i camelleri che seguono il mestieri della mercanzia dei datteri portano infinito grano per farne baratto con essi datteri.

Ancora ne' diserti di Libia, se si mutano le stagioni nella metà d'agosto e se durano le pioggie fino al novembre, ed eziandio per tutto decembre e gennaio e qualche parte di febraio, allora ne segue l'abondanza delle erbe, trovansi per tutta Libia molti laghi, e molta copia di latte. Per questa cagione i mercatanti della Barberia fanno il loro viaggio alla terra negra. In questa le stagioni incominciano più per tempo e ivi comincia a piovere nel fine di luglio, ma non piove molto, e la pioggia nella terra negra ha questa virtù, che ella né giova né fa danno, percioché alla sementa dei terreni bastano le acque del Niger, le quali crescendo rendono morbidi e fertili tutte quelle campagne non altrimenti che faccia il Nilo nello Egitto. Egli è vero che in alcuni monti fanno di bisogno le pioggie; e il Niger né più né meno cresce nel tempo che cresce il Nilo, il che è a' quindici di giugno e dura quaranta dì e altretanti decresce. E quando cresce il Niger, puossi discorrer con barche quasi tutti i paesi dei negri, percioché allora tutti i piani e le valli e i fossi diventano fiumi; ma è molto pericoloso il navicar con alcune barche che vi si usano, come nella quinta parte dell'opera abastanza descriverò.

29

\section{Brevità e lunghezza di etadi.}

Per tutte le città e terreni della Barberia le età degli uomini aggiungono per insino a sessantacinque o a settanta anni, e v'hanno pochi che questo numero passino; ma pur si 
trovano ne' monti della Barberia uomini che forniscono cento anni e alcuni che ve gli passano. E sono questi d'una gagliarda e forte vecchiezza, percioché ho veduto io vecchi d'ottanta e più anni arar la terra e zappar le vigne, e far con destrezza mirabile tutti gli altri lavori che vi bisognano; e quel ch'è più, ho veduto nel monte Atlante uomini di ottant'anni entrare in battaglia e combatter valorosamente con giovani, e molti di loro rimaner vincitori. In Numidia ancora, cioè nel paese dei datteri, sono uomini di lunga vita, ma caggiono loro i denti e molto si accorta la vista. Il cader dei denti procede dal continovo uso di mangiar datteri, e lo accortar della vista avviene perché que' paesi sono molto infestati da un vento di levante, il quale movendo l'arena la leva in alto, di maniera che la polvere offende loro molto spesso gli occhi e col tempo gli guasta. Quelli di Libia vivono quasi meno di quelli delle altre regioni, ma gagliardi e sani insino a sessanta anni o d'intorno; è vero che essi sono magri e sottili. Nella terra negra sono le vite molto più corte di quelle dell'altre generazioni, ma gli uomini stanno sempre robusti e i lor denti sono sempre fermi e a un modo: ma sono uomini di gran lussuria, sì come anco quegli di Libia e di Numidia; e quei di Barberia sono generalmente di minor forza.

\section{Infermitadi che spesse volte accadono agli Africani.}

Nel capo ai piccioli fanciulli e ancora alle donne di matura età suol nascere certa tigna, della quale se non con grandissima fatica guariscono. Da dolore di capo molti uomini sono offesi, e questo alle volte lor viene senza alcuna febbre. Dolor di denti similmente non pochi offende, e pensasi che ciò avenga percioché, mangiando essi le minestre calde, dietro di quelle beono acqua fredda. Sono eziandio molestati da doglia di stomaco, la quale per ignoranza chiamano dolor di cuore; torgimenti e passioni di corpo acutissimi a molti intervengono quasi in ciascun giorno, e questo pur per cagione dell'acqua fredda che beono. Sciatiche e dolori di ginocchi sono assai frequenti, e procedono dal sedere spesso sul terreno e dal non portar calze di sorte alcuna. Pochi sono che patiscano difetto di podagre, ma si trovano alcuni signori che l'hanno, percioché sono avezzi a ber vino e a mangiar polli e delicate vivande. Per mangiar molte olive, noci e altri cibi grossi e di niun valore lor nasce la rogna, che ad essi molto è di fastidio. A quei che sono di natura sanguigni, per seder similmente il verno in terra, si move alle volte una fiera e maligna tosse. Pigliasi piacere molte fiate il venerdì, nel 
quale essendo costume di ragunarsi nei tempi migliaia di persone, quando il sacerdote è su la più bella parte del predicare, se aviene che un tossa l'altro comincia a tossire e di mano in mano tutti quasi ad un tempo, né cessano insino al fornir della predica, di maniera che al partire nessuno l'ha udita.

Del male che nell'Italia è detto francioso io non credo che in tutte le città di Barberia la decima parte ne sia scampata, e suol venire con doglie, con bolle e con piaghe profondissime; ma molti tuttavia ne guariscono. È vero che nel contado e nei monti d'Atlante quasi niuno è offeso da questo male; similmente in tutta Numidia, cioè pure nel paese dei datteri, non si trova chi l'abbia. Né meno in Libia o in terra negra si ragiona di quello, anzi, se alcuno lo pate, tosto che si conduce in Numidia o nella terra negra, come sente quell'aere si risana e riman netto come un pesce. $\mathrm{E}$ io ho veduto con gli occhi miei quasi un centinaio di persone che, senza altri rimedii, per la mutazion sola dell'aere sono guariti. Questo tal male non era prima nell'Africa, anzi in quei luoghi niuno l'aveva sentito nominare, ma ebbe principio nel tempo che Ferrando re di Spagna cacciò di Spagna i giudei. Che, poscia che essi vennero nella Barberia, essendo molti di loro imbrattati, avenne che alcuni tristi e ghiotti Mori usarono con le loro donne e nel presero. D'indi seguitando di mano in mano s'incominciò a infettar la Barberia, in modo che non si trova famiglia che o sia netta o non abbia avuto questo male. E appresso loro per indubitata prova tiensi l'origine esser venuta di Spagna, e così gli dicono mal di Spagna; ma quei di Tunis lo chiamano francioso come gli Italiani, tra' quali molto crudele esso si ha fatto sentire per alcun tempo; così in Egitto e in Soria, dove cotal nome gli è detto.

Mal di fianco d'alcuni aviene. In Barberia pochi patiscono quel male o difetto che da' Latini è detto ernia; ma nell'Egitto molti se ne dolgono, e alle volte ad alcuni tanto si gonfiano i testicoli che è una maraviglia a vedere. Credesi che tale infermità proceda dal mangiar gomme e molto cacio salato. Il caduco spesse fiate nella Africa accade a fanciulli, ma essi venendo in età guariscono; e hannolo molte donne, massimamente nella Barberia e nella terra negra; ma per isciocchezza quei che sono inoffesi da questo male essi gli tengono spiritati. La peste nella Barberia usa venire in capo di dieci, di quindici o di venticinque anni, e leva quando viene gran quantità di gente, percioché essi non v'hanno niuno riguardo dal detto male ne vi usano rimedii, fuori che dove è la ghiandussa sogliono far certe unzioni d'intorno con terra armenica. Questa nella 
Numidia non si fa sentire se non dopo lo spazio di cento anni, ma nella terra negra ella non vien mai.

31

\section{Virtuti e cose lodevoli che sono negli Africani.}

Gli Africani, cioè gli abitanti nelle città della Barberia e massimamente nella rivera del mare Mediterraneo, sono uomini che grandemente si dilettano di sapere, e si danno con molta cura agli studi: tra' quali quello della umanità e quello delle cose della fede e delle leggi loro tengono il primo luoco. Anticamente usavano di studiar nelle discipline matematiche, nella filosofia ed eziandio nell'astrologia; ma da quattrocento anni in qua, come s'è in parte detto, molte scienzie furono loro vietate dai dottori e dai principi loro, sì come fu la filosofia e l'astrologia giudiciaria. Quelli eziandio che abitano nelle città di Africa sono molto divoti nella fede loro, obediscono ai loro dottori e sacerdoti, e hanno gran cura di saper le cose necessarie di essa fede. Vanno continovamente a fare ordinarie orazioni nei tempi, sostenendo un fastidio da non credere, di lavar per cagione delle dette orazioni molte membra, e alle volte lavano tutto il corpo, come ho meco proposto di dire nel libro secondo della fede e legge maumettana.

Sono ancora gli abitanti nelle città di Barberia uomini ingeniosi, come si vede nell'artificio di belli e diversi lavori, e sono bene ordinati e molto gentili. Sono eziandio uomini di gran bontà, né hanno molto di malizia, e tengono il vero e nel cuore e nella lingua, ancora che negli antichi secoli, come di ciò fanno fede le istorie degli scrittori latini, siano stati altrimenti tenuti. Sono uomini valorosi e di grande animo, massimamente quelli che abitano ne' monti. La fede osservano sopra tutte le cose del mondo, e prima mancarebbe in loro la vita che essi mancassero di quello che hanno promesso. Sono sopra ogni altra cosa gelosissimi, e disprezzano più tosto la vita che voglino sostenere una vergogna ricevuta per conto delle loro donne. Desiderosi di ricchezza e di onore sono oltra modo. Vanno appresso in tutte le parti del mondo mercatanti, e sono accettati per lettori e maestri in diverse scienzie: se ne veggono di ogni tempo in Egitto, in Etiopia, in Arabia, in Persia, in India e in Turchia, e dovunque essi vadino vengono molto ben veduti e onorati, percioché tutti sono sufficienti perfettamente in quella arte che hanno imparato. Sono ancora onesti e vergognosi, né 
parlano mai in publico parole disoneste. Il minore rende onore al maggiore e nei ragionamenti e in ogni altra particolarità. E tengono questo buon rispetto, che 'l figliuolo nella presenza del padre o del zio non ardisce ragionar né di amore né di giovane amata; e similmente hanno a vergogna di cantare canzone amorose, ove veggono l'aspetto dei loro maggiori. Se i fanciulli si abbattono per sorte fra ragionamenti pur d'amore, subito si dipartono da quel luogo. E questi sono i buoni costumi e le oneste creanze che sono ne' cittadini di Barberia.

Coloro che abitano ne' padiglioni, cioè gli Arabi e i pastori, sono uomini liberali, pieni di pietà, animosi, pazienti, conversabili, domestici, di buona vita, obedienti, osservatori di fede, piacevoli e di allegra natura. Gli abitanti dei monti ancora essi sono liberali, animosi, vergognosi e onesti nel viver commune. Quei di Numidia sono più di questi ingeniosi, percioché si danno alle virtù e studiano nella legge loro, ma delle scienzie naturali non hanno molta cognizione; sono uomini esercitati nelle arme, coraggiosi e molto benigni similmente. Gli abitatori di Libia, cioè gli Africani e gli Arabi, sono liberali, piacevoli e ne' bisogni degli amici s'affaticano con tutto il cuore. Veggiono volentieri bene a' forestieri; sono di gran cuore, schietti e veri. I negri sono di vita buona e fedeli, accarezzano molto i forestieri e danno tutto il loro tempo a piaceri e a far vita allegra, danzando e stando le più volte su conviti e in sollazzi di diverse maniere. Sono schiettissimi e fanno grandissimo onore agli uomini dotti e religiosi. E questi nell'Africa hanno il miglior tempo di tutti gli altri Africani che vi sono.

32

\section{Vizii e parti biasimevoli che sono negli Africani.}

Non è dubbio che queste genti, quante hanno in loro virtù, altretanti vizii non abbiano: ma veggiamo se questi vizii sono più o meno. I sopradetti abitanti nelle città della Barberia sono poveri e superbi, sdegnosi senza comparazione, e ogni piccola ingiuria scrivono, come si dice, in marmo né mai se la lasciano uscir di mente. Ispiacevoli di maniera che raro è quel forestiere che possa acquistar l'amicizia loro, sono eziandio uomini semplici e crederebbono ogni cosa impossibile. Il volgo è molto ignorante nella cognizion naturale, in modo che tutte le operazioni e moti della natura tengono assaissimi per atti divini. Sono irregolati sì nel vivere come nelle azion loro, soggetti 
alla colera grandemente, e le più volte che parlano usano parole superbe e con voce alta, e per le strade communi rara quella fiata che non se ne vegghino due o tre che facciano battaglia con le pugna. Sono di natura vile e appresso i lor signori tenuti in poco prezzo, onde si può dire che un signore faccia molte volte più conto d'una bestia che d'un suo cittadino. Non hanno né primari né procuratori che gli abbiano a reggere o a consigliare in cosa alcuna cerca al governo. Sono eziandio molto grossi e ignoranti nella mercanzia: non hanno banchi di cambio, né meno chi da una città all'altra dia spedimento alle cose, ma conviene che ogni mercatante sia presso alla sua robba, e dove quella è condotta ivi ne va il padrone. Avarissimi più di ogni altra cosa, in tanto che si trova gran quantità di uomini che mai non hanno voluto alloggiar forestieri, né per cortesia né per amor d'Iddio; e pochi ancora sono quelli che rendono il cambio a coloro da' quali hanno avuto piaceri. Sono sempre turbati e pieni di maninconia, né porgono volentieri orecchia a piacevolezza niuna, e questo aviene per esser di continovo occupati nelle bisogne del vivere, percioché la lor povertà è grande e i guadagni sono piccoli.

I pastori, così dei monti come delle campagne, vivono amaramente delle fatiche delle lor mani e stanno in continova miseria e necessità. Sono bestiali, ladri, ignoranti, né pagano mai cosa che lor si dia a credenza. E di costoro sono in maggior numero i cornuti che d'altra sorte. A tutte le giovani, prima che si maritino, è lecito d'avere amanti e di godersi dei frutti d'amore; e il padre medesimo accarezza l'innamorato della figliuola, e il fratello della sorella, di maniera che niuna porta la virginità al marito. È ben vero che come una è maritata gli amatori non la seguono più, ma si danno a un'altra. La più parte di questi non sono né maumettani né giudei, né men credono in Cristo, ma sono senza fede e senza non pur religione, ma ombra di religione alcuna, di modo che né fanno orazione né tengono chiese, ma vivono a guisa di bestie. E se pur si trova alcuno che senta qualche poco di odore di divozione, non avendo né legge né sacerdote né regola alcuna è costretto a viversi come gli altri.

I Numidi sono uomini lontani dalla cognizion delle cose, e sono ignoranti dei modi e ordini del vivere naturale, traditori, omicidi e ladri senza risguardo o considerazione alcuna. Sono vili e conducendosi nella Barberia si danno ad ogni vilissimo mistiere, e d'essi quai sono curatori di destri, quai cuochi e guatteri delle cucine e quai famigli di stalle, e infine per danari fanno ogni vituperosa operazione.

Quegli di Libia sono bestiali, ignoranti, senza lettere di niuna sorte, ladri e assassini, e vivono come fanno gli animali salvatichi. Sono eziandio senza fede e senza 
regola, e vissero in ogni tempo, e vivono, e sempre in miseria viveranno. Non è sì grande e orribile tradimento, che essi per cagione e desiderio di robba non facessero; né sono animali che più portino lunghe le corna di quello che se le porta questa canaglia. Tutto il tempo della vita loro consumano o in far male o in cacciare o in far tra lor guerra o in pascer le bestie per li diserti, e sempre vanno scalzi e nudi.

Quei della terra negra sono uomini bestialissimi, uomini senza ragione, senza ingegno e senza pratica; non hanno veruna informazione di che che sia e vivono pure a guisa di bestie senza regola e senza legge; le meretrici tra loro sono molte e per conseguente i becchi; da alcuni in fuori che abitano nelle città grandi. Essi in fine hanno poco più del sentimento umano.

Non m'è ascoso esser vergogna di me medesimo a confessare e scoprire i vituperi degli Africani, essendo l'Africa mia nudrice e nella quale io sono cresciuto e dove ho speso la più bella parte e la maggiore degli anni miei. Ma faccia appresso tutti mia scusa l'officio dell'istorico, il quale è tenuto a dire senza rispetto la verità delle cose, e non a compiacere al desiderio di niuno: di maniera che io sono necessariamente costretto a scriver quello che io scrivo, non volendo io in niuna parte allontanarmi dal vero e lasciando gli ornamenti delle parole e l'artificio da parte. E in mia difesa voglio che ai gentili spiriti e alle virtuose persone, che si degneranno di legger questa mia lunga fatica, basti lo esempio d'una brieve novelletta.

Ragionasi che nel mio paese fu un giovane di bassa condizione e di malvagia e pessima vita, il quale, per un furto di piccolo momento preso, fu condannato a essere scopato. Venuto il giorno nel quale costui dovea aver le scopature, dato in mano de' ministri della giustizia, conobbe il boia esser suo amico; laonde ei si tenne più che sicuro ch'egli a lui quel rispetto avrebbe che agli altri non era uso di avere. Ma il boia in contrario, incominciando le scopature, la prima gli diè molto crudele e incendosa, alla quale il povero compagno smarrito gridò forte: "Fratello, essendo io tuo amico, tu mi tratti molto male". Il boia allora, dandogli la seconda maggiore, rispose: "Socio, a me convien fare il mio officio come si dee fare, e qui non ci ha luogo amicizia". E seguitando di mano in mano tante ne gli diè, quante gli furono imposte dal giudice. Per il che quando io tacessi i vizii loro potrei cadere in giusta riprensione, e alcuni crederebbono che io ciò avessi fatto per avere ancora io di questi la parte mia, massimamente essendo all'incontro privo di quelle virtù che gli altri hanno. Nel che io, poi che altro a mia difesa non ho, mi propongo di tenere a punto il costume di uno 
uccello, la natura del quale se io vi voglio dire, a me conviene scrivervi un'altra brieve e piacevole novelletta.

Ne' tempi che gli animali parlavano, v'ebbe un vago e animoso uccelletto, e sopra tutto ornato d'un ingegno mirabile, il quale dalla natura aveva questo di più, che esso poteva viver così ben sotto le acque tra i pesci come sopra la terra fra gli altri uccelli. Erano tenuti tutti gli uccelli di quella età di dar ciascun anno certo tributo a il loro re. Per il che questo uccelletto entrò in pensiero di non ne pagar niuno. E in quell'ora che il re mandò a lui uno de' suoi officiali per riscuotere il tributo, il cattivello, dandogli in pagamento parole, preso un gran volo non ristette prima che fu nel mare, e si cacciò tra l'acque. I pesci, vedendo questa novità, tutti gli corsero d'intorno a larghe schiere per saper la cagione che lo aveva mosso a venir tra loro. "Ohimè, - rispose l'uccelletto, - non sapete voi uomini da bene, che 'l mondo è venuto a tale che più non si può vivere di sopra? Il poltroniere del nostro re, per certo capriccio strano che gli è venuto in capo, mi vuole isquartar vivo, non ostante alla mia bontà, che pure sono il più netto e il più da ben gentiluomo che sia fra tutti gli uccelli". E seguitò: "Per l'amor di Dio, siate contenti che io alberghi con voi, acciò che io possa dire di aver trovato più bontà negli stranieri che nei miei proprii e tra la mia gente". Si contentarono di ciò i pesci, laonde egli vi stette uno anno senza esser gravato di cosa alcuna. In capo del quale il re de' pesci, venuto il tempo di riscuoter i tributi, mandò uno de' suoi servitori all'uccelletto, faccendogli intendere il costume e chiedendogli il suo diritto. "Egli è ben dovere", disse egli, e preso il volo uscì delle acque, lasciando colui con la maggior vergogna del mondo. Infine, quante volte a questo uccelletto veniva dal re degli uccelli dimandato il tributo, egli fuggiva sotto l'acque, e quante volte esso gli era dimandato dal re dei pesci, egli tornava sopra la terra. Voglio inferire che dove l'uomo conosce il suo vantaggio sempre vi corre quando e' può. Onde se gli Africani saranno vituperati, dirò che io son nato in Granata e non in Africa, e se 'l mio paese verrà biasimato, recarò in mio favore l'essere io allevato in Africa e non in Granata. Ma di tanto sarò agli Africani favorevole, che solamente dei loro biasimi racconterò le cose che sono publiche e più palesi a ciascuno. 